\title{
WestVirginiaUniversity
}

THE RESEARCH REPOSITORY @ WVU

Graduate Theses, Dissertations, and Problem Reports

2002

\section{Use of flowable fill as a backfill material around buried pipes}

Andrew Ray Simmons

West Virginia University

Follow this and additional works at: https://researchrepository.wvu.edu/etd

\section{Recommended Citation}

Simmons, Andrew Ray, "Use of flowable fill as a backfill material around buried pipes" (2002). Graduate Theses, Dissertations, and Problem Reports. 1898.

https://researchrepository.wvu.edu/etd/1898

This Thesis is protected by copyright and/or related rights. It has been brought to you by the The Research Repository @ WVU with permission from the rights-holder(s). You are free to use this Thesis in any way that is permitted by the copyright and related rights legislation that applies to your use. For other uses you must obtain permission from the rights-holder(s) directly, unless additional rights are indicated by a Creative Commons license in the record and/ or on the work itself. This Thesis has been accepted for inclusion in WVU Graduate Theses, Dissertations, and Problem Reports collection by an authorized administrator of The Research Repository @ WVU. For more information, please contact researchrepository@mail.wvu.edu. 


\title{
USE OF FLOWABLE FILL AS A BACKFILL MATERIAL AROUND BURIED PIPES
}

\author{
By \\ Andrew Ray Simmons, B.S.C.E, E.I.T \\ Thesis Submitted to the \\ College of Engineering and Mineral Resources \\ at West Virginia University \\ in Partial Fulfillment of the Requirements \\ For The Degree of \\ Master of Science \\ in \\ Civil Engineering
}

Hema J Siriwardane, Ph.D., P.E., Chair

George Hall, Ph.D., P.E.

Udaya Halabe, Ph.D., P.E.

Department of Civil and Environmental Engineering

\author{
Morgantown, West Virginia
}

2002

Keywords: Controlled Low Strength Material, Fly Ash 


\section{ABSTRACT \\ USE OF FLOWABLE FILL AS A BACKFILL MATERIAL AROUND BURIED PIPES By Andrew Simmons}

The objective of this research work was to study the performance of flowable fill as a backfill material around buried plastic corrugated pipes. The flowable fill materials used in this study contained varying proportions of fly ash, bottom ash, river sand, waste foundry sand, and cement. The relationships between flowability and compressive strength were investigated for different mixtures by using ASTM test methods in order to design suitable mixtures that meet WVDOT materials specifications. The second phase of the research was to design and construct a laboratory-scale pipe testing apparatus. The final phase was to find the pipe-soil interactions under several variable laboratory conditions using the constructed pipe testing apparatus and different backfill materials. These variables included: trench width, pipe diameter, in-situ soil strength, backfill strength, and surcharge loading. The results of these experiments show that the fly ash based flowable fill materials can be successfully used as a backfill around buried pipes even with narrow trench widths. 


\section{ACKNOWLEDGEMENT}

Acquiring a graduate degree has been one of the most rewarding experiences of my life. After thousands of hours of work and many long nights trying to accomplish tomorrow's deadline, the end is now in sight. It is tremendously satisfying to work hard at a goal for several years. It is even more satisfying to see all of those goals come to maturity.

Along my journey I have acquired an Associate's Degree, a Bachelor's Degree, and a family. My wife, Catherine, and my son, Lucas, give meaning and purpose to my work. Catherine is my support, my encouragement, and my sanity through all times be they good or bad. My family gives me life-sustaining love and I thank them for all of their support.

I thank my advisor and chairman of the examining committee, Prof. H. J. Siriwardane, for his support and guidance during the course of this work. I also thank Prof. Siriwardane on a personal level for his friendship and understanding. I also express my appreciation to the other university professors for all of their continued guidance. I give special thanks to Dr. Udaya Halabe and Dr. George Hall for serving on the examining committee and reviewing my research. Dr. Hall also served as the project monitor from WVDOT and provided immeasurable guidance and direction to the research.

Special recognition is warranted for the workers at Morgantown Energy Associates. Norman Cloud as well as the rest of the staff were exceptionally helpful in providing me with a continuous supply of fly ash and bottom ash that was needed for this research.

I also acknowledge the financial support provided by the West Virginia, Department of Transportation (WVDOT) through a research contract with West Virginia University. 


\section{TABLE OF CONTENTS}
ABSTRACT ii
ACKNOWLEDGEMENT .................................................. ii
TABLE OF CONTENTS ..................................................... iv
LIST OF FIGURES ............................................................. vi
LIST OF TABLES .............................................................. vii

\section{CHAPTER 1}

GENERAL INTRODUCTION ......................................... 1

$1.1 \quad$ Controlled Low Strength Material................................. 1

$1.2 \quad$ Buried Pipes..................................................... 5

$1.3 \quad$ Research Objectives............................................. 9

\section{CHAPTER 2}

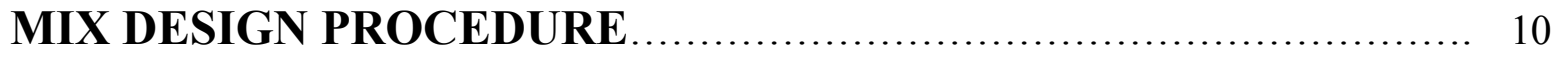

$2.1 \quad$ Material Information............................................... 10

$2.2 \quad$ Flowability Testing ................................................ 16

$2.3 \quad$ Strength Testing................................................. 20

$2.4 \quad$ Penetration Resistance........................................... 30

\section{CHAPTER 3}

DESIGN OF THE TESTING APPARATUS ......................... 33

3.1 Specific Goals of the Pipe Testing Apparatus........................... 33

3.2 Structural Design of the Pipe Testing Apparatus....................... 34

3.2.1 Requirements for Operating Pressure of $70 \mathrm{psi}(480 \mathrm{~Pa}) \ldots \ldots \ldots \ldots . .34$

3.2.2 Requirements for Operating Pressure of $30 \mathrm{psi}(207 \mathrm{~Pa}) \ldots \ldots \ldots \ldots . . .39$

3.2.3 Design of the Reaction Frame.................................. 39

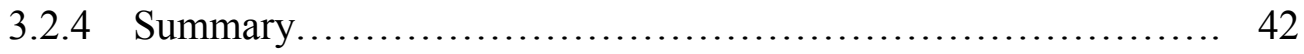

$3.3 \quad$ Data Collection .................................................. 43

$3.4 \quad$ Pipe Testing Apparatus................................................. 46 


\section{CHAPTER 4}

EXPERIMENTAL PROCEDURES _.................................. 48

$4.1 \quad$ In-Situ Soil Preparation.................................................. 48

$4.2 \quad$ Preparation of the Test Box........................................ 51

$4.3 \quad$ Operational Procedures........................................... 52

\section{CHAPTER 5}

EXPERIMENTAL RESULTS .......................................... 54

$5.1 \quad$ Experimental Variables ........................................ 54

5.2 Pipe Deflections Due to Surcharge Loading........................... 56

$5.3 \quad$ Soil Stresses Due to Surcharge Loading............................... 61

$5.4 \quad$ Soil Stresses Due to Direct loading................................... 66

$5.5 \quad$ Summary of Results............................................... 66

\section{CHAPTER 6}

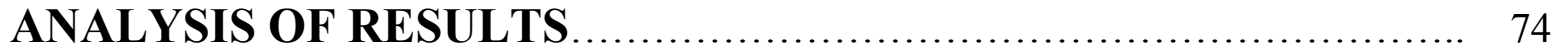

$6.1 \quad$ Numerical Analysis.............................................. 74

$6.2 \quad$ Predicted Deflections........................................... 76

6.3 Calculated Modulus of Soil Reaction .............................. 81

\section{CHAPTER 7}

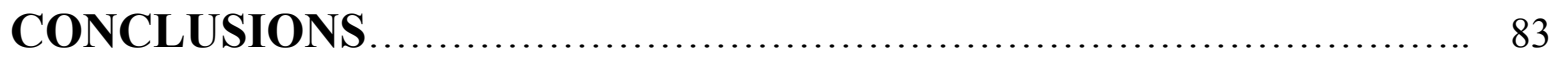

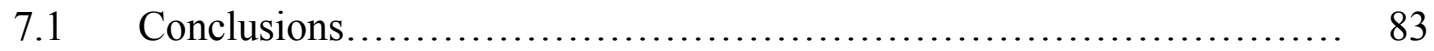

7.2 Recommendations for Further Research............................. 85

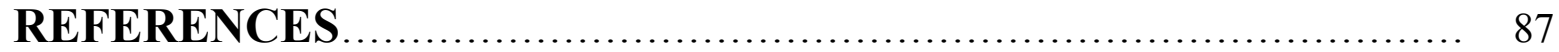

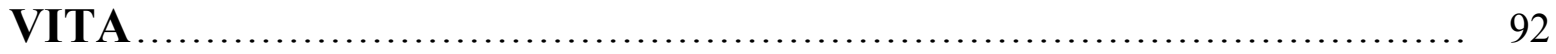

\section{APPENDIX}

A. Data From Flow Testing........................................... 93

B. Data From Compressive Strength Testing............................. 101

C. Data From Pipe Testing.......................................... 133

D. Calculations For The Testing Apparatus............................. 142 


\section{LIST OF FIGURES}

Figure 1.1 Schematic Diagram of A Buried Pipe .............................. 8

Figure 2.1 Gradation Curves for Aggregates in Flowable Fill..................... 13

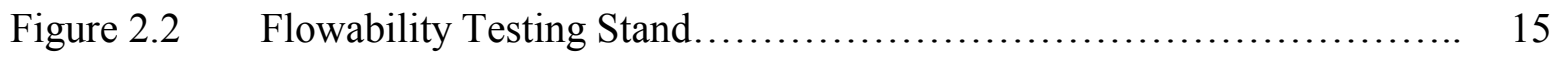

Figure 2.3 Water Content vs. Spread for River Sand Mixtures.................... 18

Figure 2.4 Water Content Versus Percentage of Aggregate for 9 inch $(23 \mathrm{~cm})$ Spread 19

Figure 2.5 Strength Curves for Ohio River Sand Mixtures........................ 26

Figure 2.6 Strength Curves for Foundry Sand Mixtures........................... 27

Figure 2.7 Strength Curves for Bottom Ash Mixtures........................... 28

Figure 2.8 28-Day Strength Curves for Bottom Ash and Cement Mixtures.......... 29

Figure $2.9 \quad$ Penetration Resistance Testing Results.............................. 32

Figure 3.1 Schematic of the Testing Apparatus without the Reaction Frame......... 36

Figure $3.2 \quad$ Geometry of Welded Areas.......................................... 38

Figure $3.3 \quad$ Schematic of the Reaction Frame.................................. 40

Figure 3.4 Configuration of Instrumentation................................... 45

Figure $3.5 \quad$ Completed Pipe Testing Apparatus.................................... 47

Figure $4.1 \quad$ Prepared Trench for the Pipe...................................... 49

Figure 5.1 Deflections of Pipes in Cohesive In-Situ Soil with Low Strength Backfill. 56

Figure 5.2 Deflections of Pipes in Cohesive In-Situ Soil with High Strength Backfill. 57

Figure 5.3 Deflections of Pipes in Loose In-Situ Soil with Low Strength Backfill.... 58

Figure 5.4 Deflections of Pipes in Loose In-Situ Soil with High Strength Backfill... 59

Figure 5.5 Soil Stresses in Cohesive In-Situ Soil with Low Strength Backfill......... 62

Figure 5.6 Soil Stresses in Cohesive In-Situ Soil with High Strength Backfill........ 63

Figure 5.7 Soil Stresses in Loose In-Situ Soil with Low Strength Backfill............ 64

Figure 5.8 Soil Stresses in Loose In-Situ Soil with High Strength Backfill........... 65

Figure 5.9 Soil Stresses in Cohesive In-Situ Soil with Low Strength Backfill

During Direct Loading Experiments.................................. 67

Figure 5.10 Soil Stresses in Cohesive In-Situ Soil with High Strength Backfill

During Direct Loading Experiments............................... 68

Figure 5.11 Soil Stresses in Loose In-Situ Soil with Low Strength Backfill

During Direct Loading Experiments................................ 69 
Figure 5.12 Soil Stresses in Loose In-Situ Soil with High Strength Backfill

During Direct Loading Experiments............................... 70

Figure 5.13 CLSM with Micro Cracks Over the Centerline.......................... 73

Figure 6.1 Measured versus Predicted Deflections for Tests on 6 inch Pipe.......... 79

Figure 6.2 Measured versus Predicted Deflections for Tests on 8 inch Pipe......... 80 


\section{LIST OF TABLES}

Table $2.1 \quad$ Flowability Mixtures...................................... 16

Table $2.2 \quad$ Low Compressive Strength Mixes................................ 21

Table $2.3 \quad$ High Compressive Strength Mixes.............................. 22

Table 3.1 Summary of Design Results................................. 44

Table 5.1 Summary of Surcharge Loading Maximums and Minimums............ 71

Table 6.1 $\quad E_{\text {com }}^{\prime}$ Values for the Different Geometries............................ 77

Table 6.2 Predicted Deflections Compared to Measured Deflections at 20 psi...... 78

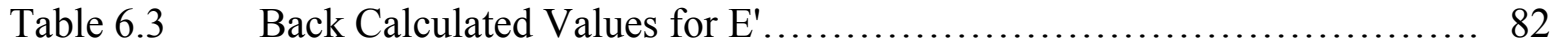




\section{CHAPTER 1}

\section{GENERAL INTRODUCTION}

\subsection{Controlled Low-Strength Material}

Controlled low strength material or CLSM, is a common term for the material also known as flowable fill or K-Krete (Bhat and Lovell 1996). K-Krete Inc. was a company formed in the early 70's as a joint venture between a power plant trying to find more use for its fly ash and a cement company trying to find more use for their cement trucks. K-Krete Inc. specialized in the manufacturing of flowable fills and patented their procedures. By 1974 K-Krete Inc. was nation-wide and in 1977 it was sold (Hitch 1998). Through the 70's many other companies began to produce similar products but there was very little control of these products.

In the early 80 's some attempts were made to standardize the technologies and testing procedures for flowable fills. Flowable fills do not fit in perfectly with concrete testing standards and they do not fit in perfectly with soil testing standards either. One of the first attempts to establish national standards to control these mixtures was with the formulation of ACI committee 229 on Controlled Low Strength Materials in 1982 (Brewer 1990). The American Concrete Institute has helped to standardize the use of CLSM and since the inception of committee 229 many new ASTM standards have been written that deal solely with CLSM. The following five ASTM standards deal solely with CLSM (ASTM 2000)

- D 4832: ASTM Test Method for Preparation and Testing of Controlled Low Strength Materials (CLSM) Test Cylinders.

- D 5791: ASTM Practice for Sampling Freshly Mixed Controlled Low Strength Material.

- D 6023: ASTM Test Method for Unit Weight, Yield and Air Content (Gravimetric) of Controlled Low Strength Material.

- D 6024: ASTM Test Method for Ball Drop on Controlled Low Strength Material to Determine Suitability for Load Application.

- D 6103: ASTM Test Method for Flow Consistency of Controlled Low Strength Material 
CLSM's are characterized by their ability to flow under their own weight, and harden to a strength that is equal to or greater than that of compacted soil. These mixtures typically contain fly ash, cement, and an aggregate. However, many companies and State specifications have provisions for mixtures that do not use any fly ash. These are usually sand-cement mixtures that have faster curing times and are commonly referred to as quick-set flowable fill (Landwermyer and Rice 1999). The ASTM definition of CLSM's does not specify any required ingredients other than water. ASTM defines a CLSM as "A mixture of soil, cementitious materials, water, and sometimes admixtures, that hardens into a material with a higher strength than the soil but less than 1200 psi” (ASTM 2000). Since one of the objectives of the present research project was to establish mix designs that would use the maximum amount of waste material, no mixtures were prepared that did not contain fly ash.

Fly ash represents $50 \%$ of the by-product waste stream from coal burning power plants, but only $25 \%$ of it is utilized. The other $50 \%$ of the coal power waste is bottom ash, which is more heavily utilized and is considered an acceptable material for the aggregate in CLSM's (Monson 1996). Environmentally speaking, CLSM's that contain waste materials are a very beneficial product because it reduces the need for landfilling the waste and reduces the transportation costs of moving the waste to the landfill. Other waste materials that have been included in flowable fill include: crushed glass, chipped tires, crushed concrete aggregates, AMD sludge, and waste foundry sand (Hook 1998). These materials have been used for backfill and pipe trenches for a couple of decades, but since there is a wide variety of mix designs and applications there is still a great need for research (Brinkley 1998).

CLSM's have gained the most popularity in filling trenches, but have also been used for structural fill, thermal fill, slope stabilization and highway subgrades. In trenching, using a flowable mixture that can fill all of the voids from the top of the trench can greatly reduce the number of workers in overhead trenches. These materials harden in less time than it would take to fill the trench in layers and compact each layer, so there is less investment in labor and less inconvenience to travelers (Ramme 1999). Digging much narrower trenches can even further reduce the labor costs, because the trenches do not need to accommodate compaction equipment (Hegerty and Eaton 1998). In addition, 
these materials exhibit very little settlement, which is a strong benefit when compared to compacted fills that can have destructive settlement problems (Bhat 1998). Flowable fills also exhibit uniform density and strength properties from the top of the trench to the bottom. With all of these considerations in mind, flowable fills are often the most economical way to fill an excavated trench. One study showed that strong CLSM's will reduce the stresses and deflections experienced in pipes, especially those buried at shallow depths (McGrath and Hoopes 1998). The potential savings in labor, the increased safety of the workers, the utilization of waste materials, and the quicker construction times that present less inconvenience to the general public are making this material a popular choice with transportation departments around the country.

These benefits have led many states to consider using flowable fill in many more fill situations than before. The West Virginia Department of Transportation has specifications for three types of CLSM's. Class A and class B mixtures are the typical lower strength materials. Class A has a minimum 28-day compressive strength of $50 \mathrm{psi}$ (345 Pa) and a maximum 28-day compressive strength of $300 \mathrm{psi}(2,070 \mathrm{~Pa})$. Class B has a minimum compressive strength of $50 \mathrm{psi}(345 \mathrm{~Pa}$ ) and no upper limit on the compressive strength. Class A and B mixtures would be used in a utility trench that might expect future excavation. The lower strength material will facilitate easy excavation if the utility needs future repairs. Class C CLSM must have a 28-day unconfined compressive strength in excess of 1,000 psi $(6,900 \mathrm{~Pa})$. This implies that the upper limit for Class B mixtures is $1,000 \mathrm{psi}(6,900 \mathrm{~Pa})$ because if it exceeded this number it would be a Class $\mathrm{C}$ mixture. Class $\mathrm{C}$ mixtures are likely to be in excess of the ASTM definition that requires a CLSM to be under $1,200 \mathrm{psi}(8,270 \mathrm{~Pa})$, but they are very useful in applications that will not need to be excavated in the future. Results from a previous study (Mullarky 1998) showed that the percentage of fly ash and the air content would affect the longterm strength gain of CLSM mixtures. This report indicated that mixtures with high fly ash contents are likely to continue gaining strength well after 28 days.

Current construction methods practiced by the West Virginia Department of Transportation (WVDOT) are described in their construction specification book (WVDOT 2000). It appears that the WVDOT does not use any pipes smaller than 18 inches $(45.7 \mathrm{~cm})$ in any new construction (WVDOT 2000). A trench must have at least 1- 
diameter on each side of the pipe for an 18 inch $(45.7 \mathrm{~cm})$ pipe and the specification continues to only require 18 inches $(45.7 \mathrm{~cm})$ on each side of the pipe for pipes up to 54 inches $(137 \mathrm{~cm})$ in diameter. All pipes 60 inches $(152 \mathrm{~cm})$ and larger in diameter require at least one diameter on each side. So the specifications primarily require a trench to be three times the diameter but pipes between 18 inches $(45.7 \mathrm{~cm})$ and 54 inches $(137 \mathrm{~cm})$ do not appear to have this requirement. A 54 inch $(137 \mathrm{~cm})$ pipe can be laid with a trench width-to-diameter ratio of only 1.67. Of course, this only applies to new construction. Maintenance or rehabilitation projects on existing pipe have different standards. The construction specification also requires that all pipes be trenched. This means that when a fill is being constructed, the soil must first be built up and then trenched to lay the pipe. This insures that there will be enough surrounding soil pressure to protect the pipe.

Flowable fill has some drawbacks that can be easily avoided. If the mixture does not contain enough water all of the voids may not get filled. Moreover, if too much cement is added then future excavations will be very difficult. Pipe floating needs to be prevented by bracing. The mixture can flow into the pipe if any of the joints are not properly seated. In addition to these human errors, there are complaints about the high variability of fly ash sources (ACI 1999). This variability causes the need for constant testing. Subsidence is listed by ACI as a potential problem. Subsidence is caused by a reduction in volume due to the loss of water either to the surrounding soil or as bleed water. An advantage to CLSM is that the subsidence happens early. Typical subsidence is about $1 / 4$ inch per foot $(2 \mathrm{~cm}$ per meter) of depth for high water content mixtures. Some mixtures will also be prone to segregation. It is typically up to the contractor to make sure that the mixtures do not segregate. Another drawback is that the strength tests are usually conducted no less than seven days after the pouring. If a problem in the mixture is not detected until seven days after the construction it will be very hard to correct the mistake. In the case of compacted fill a nuclear density gage can be used to determine whether or not the required densities have been met before proceeding any further (Webb et al. 1998).

Meeting the requirements of the CLSM is solely up to the contractor. Most contractors work from experience to estimate the strength they will get from different combinations of ingredients. ACI committee 229 on Controlled Low Strength Materials 
does not give any mix design information but does say that any samples should be tested to see what effects the ingredients have (ACI 1999). Many transportation departments have very strict mix design criteria and a lot of research has been done on mix designs. The chemical properties of the aggregates can have a significant affect on the strength while the gradation of the aggregate will affect both flowability and strength. It has also been shown (Brewer 1993) that the initial water content will affect the strength. The strength of a mixture can be adjusted by adjusting the water content. More water can be added to reduce the strength or the mixture can be a little dry to increas the strength

Because of the popularity of flowable fill materials with transportation departments it has also been considered for many other applications as well. For instance, since the material can easily be pumped into tunnels and cavities, it has been used for filling abandoned tunnels and sewers. Flowable fill has also been used for backfilling abandoned mines (Gray 1998). Flowable fill is useful when space is limited, and has been used for fill around embutments for bridges both in construction and maintenance (Hook 1998). CLSM can be used in subgrades and was found useful in approach embankments for bridges (Snethen and Benson 1998). CLSM has been used to fill the voids on The Boston Harbor Tunnel Project (The Big Dig) (Sullivan 1999). There are innumerable instances when limited space or accessibility can make flowable fill the best option.

\subsection{BURIED PIPES}

This research deals with the interaction between flowable fill and buried pipe, and some background information on the design and testing of buried flexible pipes is given in this section. One of the first recorded uses of flowable fill was the use of soil-cement slurry for pipe bedding in the early 1960's. The project was a 296 mile (410 km) long pipe on the Canadian River Project in Texas (Hitch 1998). The use of soil cement slurries by the Bureau of Reclamation has been sporadic even though this early project worked quite well. However, the work done in Texas led to the first draft of ASTM Test Method

for Preparation and Testing of Soil-Cement Slurry Test Cylinders (D 4832). In 1997 a slightly altered form of this test method was officially adopted and the title "Soil Cement Slurry" was replaced by "Controlled Low Strength Material." From the beginning flowable fill has been recognized for its beneficial use with buried pipes. 
This research deals with buried flexible pipes, which have very different properties and design procedures than stiff pipes. Flexible pipes deflect under the vertical loading which causes a decrease in the vertical stress directly above the pipe and an increase in the horizontal pressures (Journal 1991). This vertical stress decrease, known as arching, is caused because the deflection in the pipe allows the soil mass above the pipe to slip downwards. As the fill material slips, the friction forces between the in-situ soil and the fill increase and reduce some of the vertical stress on the pipe. The horizontal stress increases because the pipe is pushing outward towards the soil. A proper flexible pipe design should take into consideration strength characteristics of the in-situ soil and fill material, and the bending characteristics of the pipe (Daniels 1990).

The equation used for computing horizontal pipe deflections differs slightly in different texts, but they all have the following form (Bulson 1985).

$$
\Delta X=\frac{\text { loading parameter }}{\text { ring stiffness factor }+ \text { soil stiffness factor }}
$$

This is known as Spangler 's Iowa equation (Bulson 1985). In addition to this equation, it is known from the fundamental static equations that govern deflections in a ring that the magnitude of the horizontal deflections is $91.3 \%$ of the vertical deflections (Bulson 1985). However, this ratio between vertical and horizontal displacements was derived from a simple example using an unsupported ring with diametrically opposed forces. In a buried pipe, there is support around the whole structure that will vary in the vertical and horizontal directions and because of variability in the compacted fill, the real deflected shape of a buried pipe will not be represented by such simple static relationships.

Soil stiffness factors are highly variable and will not only depend on the type of soil but also on the level of compaction and the quality of compaction. The highest values for a densely compacted sand or gravel will be about 100 times higher than the value for a fine grained soil of medium plasticity (Howard 1996). One of the benefits to using flowable fill is the uniform nature of the fill. It is not as variable as compacted fills because it's strength is controlled, it is more homogeneous than many fills, and it will leave no voids under or around the buried pipe.

The ring stiffness factor is related to the bending characteristics of the pipe. Many commercial flexible pipes are available in a wide range of strengths. The selection of a 
pipe will depend on the anticipated loading conditions and the soil stiffness. It can be seen from Equation 1.1 that if the loading conditions and the soil stiffness are known, a value for the maximum allowable deflection can be assumed to solve for the required pipe stiffness. A contractor then only needs to pick a pipe that meets the calculated criteria. By using the Iowa equation, it has been shown that the deflections of a pipe will be reduced by $1 / 2$ if you use CLSM rather than conventional backfill (Brewer 1990). In this reference it has been assumed that all material, fill, and soil properties are the same. It has been shown that CLSM backfill can affect every stage of flexible pipe design, from vertical load estimation to selection of the pipe size and trench width requirements (Brewer 1993).

Another phenomena found in HDPE flexible pipes is stress relaxation. If a certain load is applied to a pipe to force it to $5 \%$ deflection instantaneously, and the load is measured with time, over time the load required to hold the pipe at $5 \%$ deflection will reduce. The pipe gets set at its new shape and has a reduction in internal stresses (Daniels 1990). Stress relaxation is only found in pipes that are held at a certain deformation for a long time. All of the tests conducted in this research deal with instantaneous loading so the details of this theory are not discussed in this report.

Finite Element Analysis Method (FEM) is also a valuable tool for measuring buried pipe deflections (Zaman and Laguros 1990). The Iowa equation is good for simple geometries but it does not give a complete picture of the pipe-soil interactions. FEM has the power to find the deflections around the whole perimeter of the pipe, as well as the interactions between the soil interfaces. Using FEM the entire geometry is discretized into interconnected elements. By knowing some of the values in the system and knowing the boundary conditions in the system, the unknown displacements and stresses can be determined. Several programs exist for designing pipes using finite element method. Culvert Analysis and Design (CANDE) is a commonly used program for such applications (Katona et al. 1976)

In the following figure (Figure 1.1), a schematic of a buried pipe is shown. The geometry for a typical trench filled with compacted earth, and the geometry that might be used when using CLSM as the backfill are both shown in Figure 1.1. Trenches filled with 


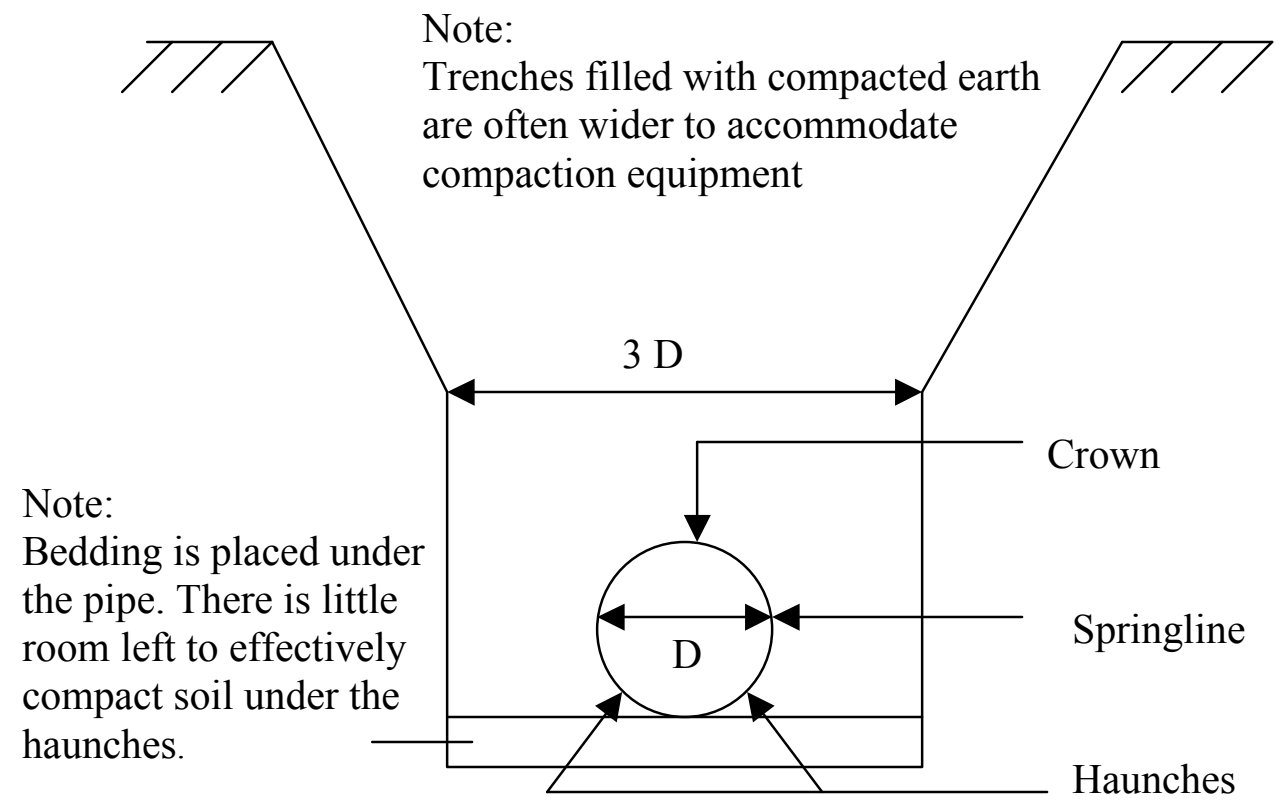

a.) Trench Geometry for Compacted Earth

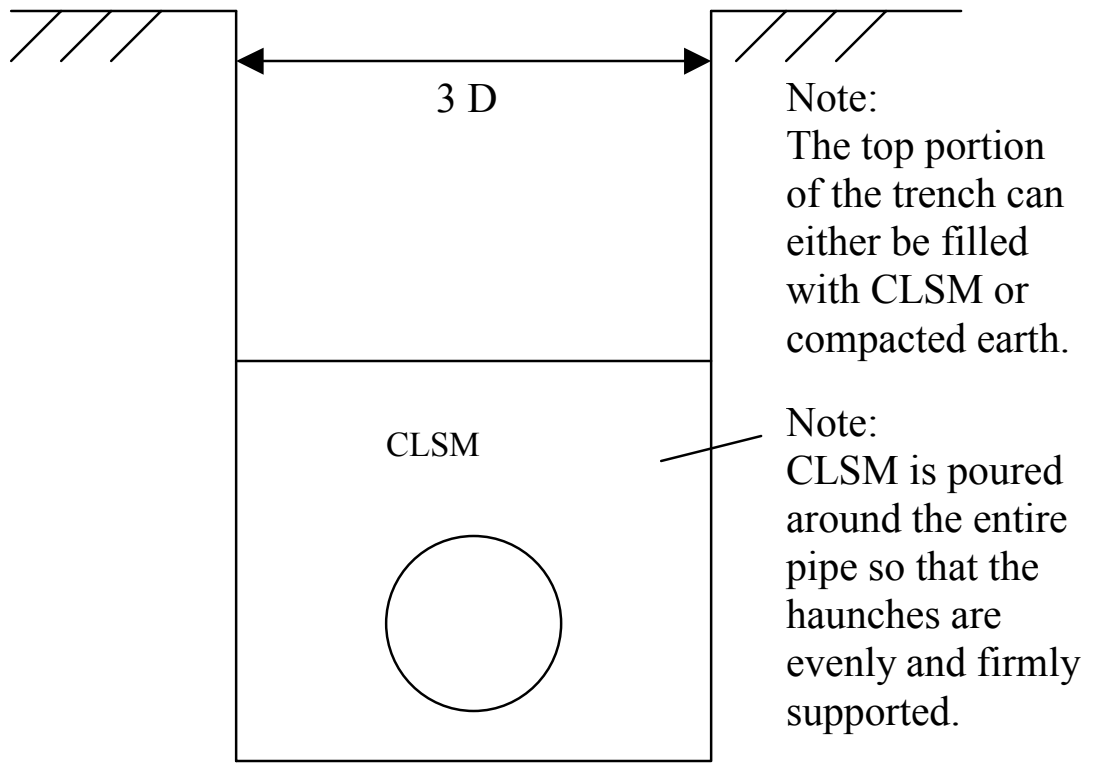

b.) Trench Geometry for Controlled Low Strength Materials

Figure 1.1: Schematic Diagram of a Buried Pipe 
CLSM can be narrower because CLSM offers better support under the haunches of the pipe (Brewer 1993).

\subsection{Research Objectives}

Specific objectives of the research are listed below.

1.) Determine strength and flowability information for mixtures that will incorporate at least two different aggregate types. The percentage of aggregate should be varied such that data can be useful to relate the strength and flowability to the percentage of aggregates in the mixture.

2.) Develop a mix design procedure based on this information.

3.) Choose two mixtures for pipe testing. One high strength mixture meeting the requirements for a WVDOT class C CLSM mixture and one low strength mixture meeting the requirements for a WVDOT class B mixture.

4.) Design and construct a testing apparatus for laboratory testing of 6 inch (15 $\mathrm{cm})$ and 8 inch $(20 \mathrm{~cm})$ corrugated plastic pipes. The device should be sufficiently instrumented to measure the external applied loads, deflections, and soil stresses.

5.) Conduct laboratory pipe tests with the constructed apparatus to find the relationships between trench width, pipe size, deflections and soil stresses for different backfill strength and in-situ soil strength.

6.) Analysis of laboratory data and preparation of the final report.

The details of these objectives are presented in the following chapters of this report. 


\section{CHAPTER 2}

\section{DESIGN PROCEDURE}

Information on all of the materials used in this research is presented in this chapter. The research that was performed in order to develop a mix design procedure is also discussed. This research includes flowability testing and compressive strength testing. All of these tests were conducted according to ASTM standards. Tables and graphs are presented to support the information in the body of this chapter.

\subsection{MATERIAL INFORMATION}

Controlled low strength materials consist of aggregates and cement and they may contain some fly ash and some admixtures to improve flowability or set time. Fly ash can vary widely from one geographical region to another so it is important to characterize the fly ash. The West Virginia Department of Transportation (WVDOT) gives the following specifications for an approved class $\mathrm{C}$ fly ash:

1) Amount retained on \# 325 sieve must be less than $34 \%$

2) Loss on ignition must be less than $12 \%$

3) $\left(\mathrm{SiO}_{2}+\mathrm{AlO}_{3}+\mathrm{Fe}_{2} \mathrm{O}_{3}\right)$ must be greater than $50 \%$

The fly ash used for the experiments outlined in this report was obtained from Morgantown Energy Associates (MEA) in Morgantown, West Virginia. Based on unpublished data (personal communication with MEA 2002), it was found that the average loss on ignition is $2 \%$ for the fly ash and $1 \%$ for the bottom ash. This reference also reported the percentage of $\left(\mathrm{SiO}_{2}+\mathrm{AlO}_{3}+\mathrm{Fe}_{2} \mathrm{O}_{3}\right)$ to be $63 \%$ and the Calcium Oxide $(\mathrm{CaO})$ content was reported as $18.2 \%$ to $19.0 \%$. A sieve analysis showed that $85 \%$ passed the \#325 sieve. No gradation curve can be formed for the fly ash because it did not settle independently in a hydrometer analysis. In addition to this information, the dry unit weight, specific gravity, and water content were also measured. They were found as follows:

$$
\begin{array}{ll}
\text { Dry unit weight, } \gamma_{\text {dry }} & =42.9 \mathrm{lb} / \mathrm{ft}^{3}\left(6.7 \mathrm{kN} / \mathrm{m}^{3}\right) \\
\text { Specific gravity, G } & =2.78 \\
\text { Water content, } \mathrm{w} & =0.13 \%
\end{array}
$$


These numbers are all in the expected ranges. The water content is so low because the material is poured directly into a large steel drum from the furnace, which is at a temperature of $400^{\circ} \mathrm{C}$. The containers are then sealed and stored in a dry location until the fly ash is used. An attempt was made to measure the liquid and plastic limits but this material is non-plastic and the results were not conclusive. Neither ASTM nor AASHTO have recommendations for these tests.

Other research has shown that fluidized bed fly ash is higher in sulfur than a typical fly ash (Ziemkiewicz and Black 2000). MEA is authorized to burn lower quality coal than most other plants in West Virginia because they use fluidized bed combustion (Howard 1983). There are only two fluidized bed combustion plants in West Virginia. The other constituent in fly ash that is of concern is Calcium Oxide $(\mathrm{CaO})$. This is the main cementing ingredient in Portland cement (Hibbeler 1997). Fly ash naturally contains some $\mathrm{CaO}$ and the percentage of this compound will greatly affect the pozzolanic behavior of the ash. As stated earlier the $\mathrm{CaO}$ content in fly ash coming from MEA varies between $18.2 \%$ and $19.0 \%$. ASTM reports an expected $\mathrm{CaO}$ content as $24 \%$ for a class C fly ash so the values found in the MEA ash is not far below the expected values (Ziemkiewicz and Black 2000).

Several aggregates were chosen for testing. The first is the bottom ash from MEA, the second is Ohio River Sand commercially available in Morgantown, West Virginia, and the third is foundry sand obtained from a West Virginia foundry.

The dry unit weights of the three aggregates are as follows:

$$
\begin{aligned}
& \text { Bottom Ash }=82.8 \mathrm{lb} / \mathrm{ft}^{3}\left(13.0 \mathrm{kN} / \mathrm{m}^{3}\right) \\
& \text { River Sand }=99.2 \mathrm{lb} / \mathrm{ft}^{3}\left(15.6 \mathrm{kN} / \mathrm{m}^{3}\right) \\
& \text { Foundry Sand }=94.4 \mathrm{lb} / \mathrm{ft}^{3}\left(14.8 \mathrm{kN} / \mathrm{m}^{3}\right)
\end{aligned}
$$

The grain size distributions of each material were also measured and the gradation curves of all three materials are shown in Figure 2.1 with respect to the WVDOT aggregate specifications. The bottom ash has an additional regulation that it has a loss on ignition no greater than $12 \%$. The bottom ash used in this study has a loss on ignition of $1 \%$ (personal communication with MEA 2002). The cement used in testing was normal type I Portland Cement. 
Morgantown Energy Associates (MEA) does not separate their bottom ash from their fly ash under normal operating procedures. Both materials are dumped onto the same conveyor and then stored in silos in the mixed condition for disposal. This company was extremely helpful by filling the barrels of fly ash and bottom ash directly from the supply lines leaving the furnace. The bottom ash had no measurable water content because it was put into a container directly after leaving the furnace. The bottom ash also contains $\mathrm{CaO}$ so it also contributes to the pozzolanic activity of the CLSM mixture.

The Ohio River sand used in CLSM mixtures is also used for the loose in-situ soil in the pipe testing apparatus. It should be noted that only the portion of sand passing the $3 / 8$ inch $(9.5 \mathrm{~mm})$ sieve was used in CLSM mixtures. This sieve does not affect the gradation of the sand. It serves to remove any leaves, litter, or gravel that inadvertently fall into the sand.

The foundry sand is a fine uniformly graded material. The foundry sand was only used for flowability and strength testing because it was in limited supply. There was not enough material for use in the pipe testing. Additional research on flowable fill mixtures with foundry sands can be found elsewhere. Information on designs utilizing different proportions of waste foundry sands can be found in the literature (Bhat and Lovell 1996; Bhat and Lovell 1998). Other literature is also available that describes adding other waste materials, such as phosphogypsum and acid mine drainage (AMD) sludge, to CLSM mixtures (Landham et al. 1996; Monson 1997). 
Gradation of Aggregates With Respect to WVDOT Specifications

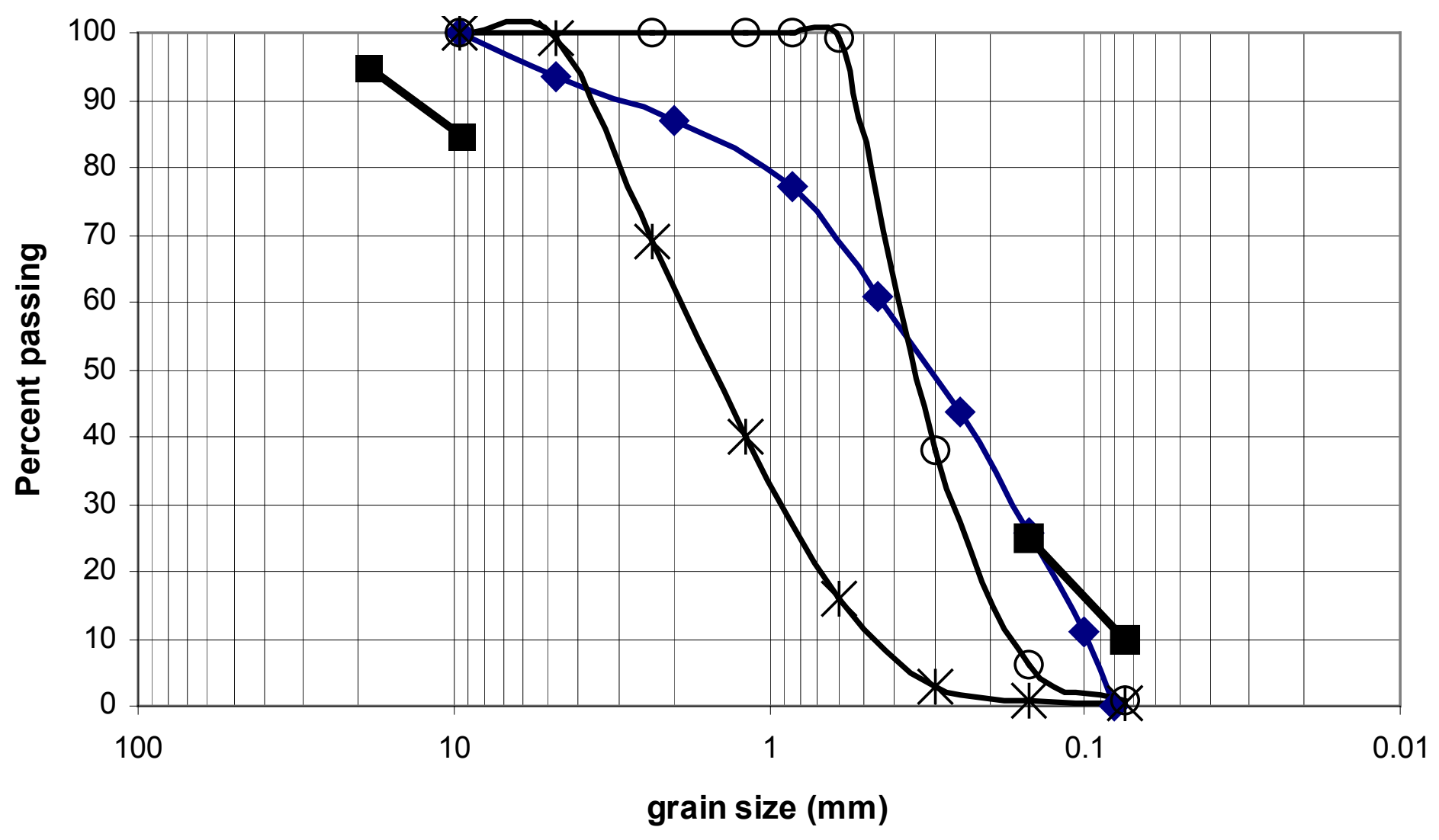

$\neg$ Bottom ash $\rightarrow$ River sand $\_$Foundry sand $\rightarrow$ WVDOT Spec

Figure 2.1 Gradation Curves For Aggregates in Flowable Fill 


\subsection{Flowability Testing}

Details of flowability testing of CLSM are given in ASTM specification D6103 (ASTM 2000). This test was adopted as an official ASTM standard in 1997. It gained provisional status in 1995. Prior to the adoption of this standard, many companies judged flowability by eye and relied on the experience of their workers to produce a quality material. Some companies attempted to apply slump tests to flowable fills but for very flowable mixes the slump test does not give meaningful results.

The flowability test consists of a non-porous surface and a 3 inch $(7.6 \mathrm{~cm})$ diameter by 6 inch $(15.2 \mathrm{~cm})$ high cylinder. The cylinder is filled with the CLSM and lifted in a non-twisting uniform motion so that the CLSM will spill onto the non-porous surface. The diameter of the spill is measured in at least two perpendicular directions and their average value is recorded as the spread. ASTM recommends that the spread be between 8 inch $(20 \mathrm{~cm})$ and 12 inch $(30 \mathrm{~cm})$ for an adequate CLSM mixture. WVDOT only requires that the material have a spread of 6 inch $(15 \mathrm{~cm})$, but it gives the additional requirement that the material must be able to fill all voids without vibration or roding. ASTM also requires that the cylinder be lifted in a straight non-twisting and non-jarring motion. To ensure the accuracy of these tests, a testing frame was built. The frame provides a rigid and level glass spill surface with two perpendicular axis for measuring the spill diameter. The constructed frame also has a handle for lifting that insures a strait and non-jarring lift. The test stand is illustrated in Figure 2.2.

Table 2.1 shows all of the materials that were tested for flowability. All of the values in this table show the percentage by weight of the various materials. This set of experiments generated data on the flow characteristics of each aggregate as well as the flow characteristics of any admixtures. The tests clearly showed that replacing up to $3 \%$ of the fly ash with cement had almost no effect on the flow characteristics. The testing also showed that bentonite decreased the flowability of the material so it was removed from further consideration as an admixture.

Each mix was placed in a bowl and water was gradually added. Four samples were used to find the water content at four different diameters of spread for each mix. It was attempted to find some water contents that would correspond to flow below the ASTM minimum requirement of 8 inch $(20 \mathrm{~cm})$ and some water contents that would 


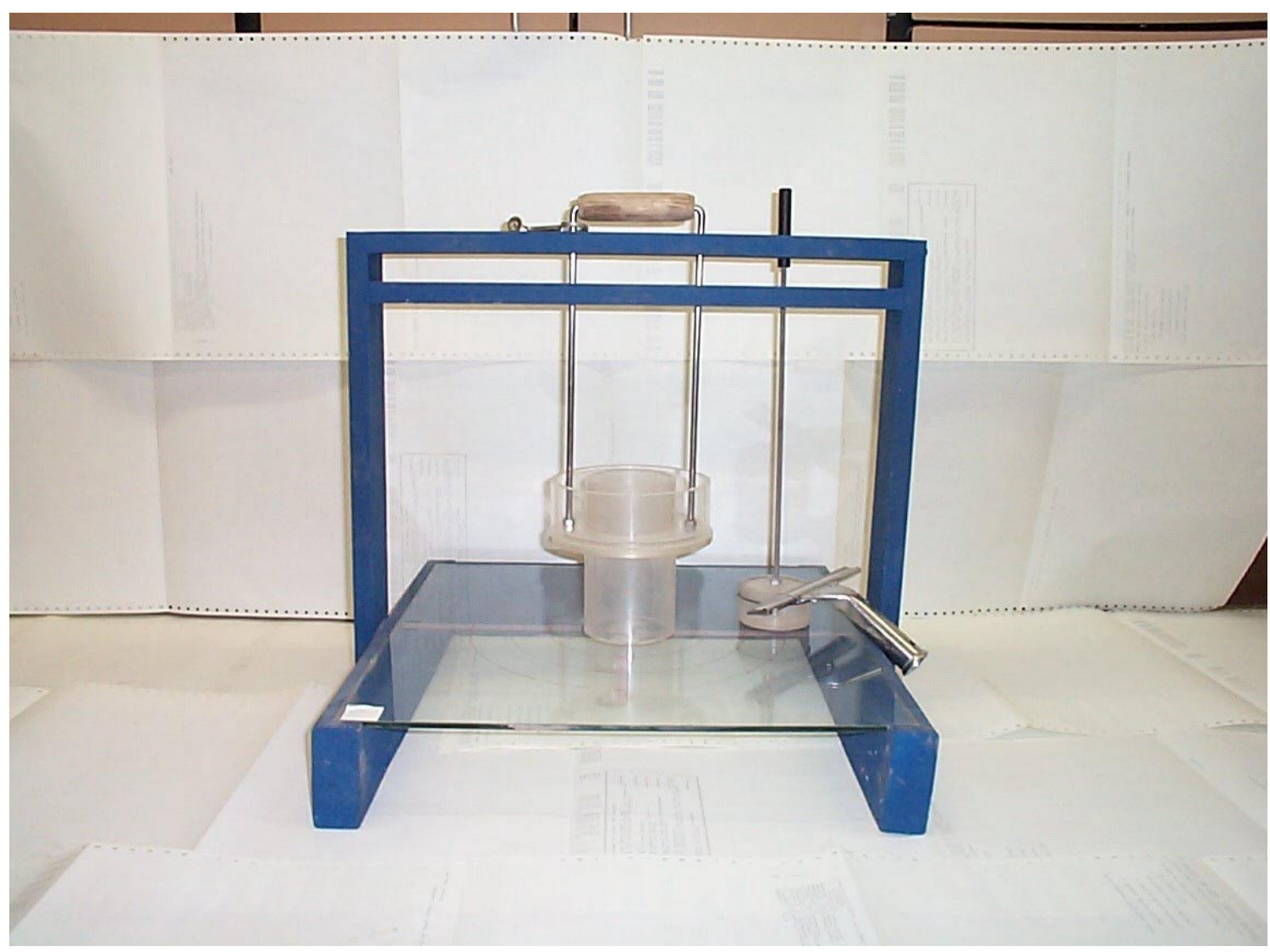

Figure 2.2: Flowability Testing Stand 
Table 2.1: Mixtures Tested for Flowability

\begin{tabular}{|c|c|c|c|c|c|c|c|}
\hline & & Percentá & of Dry Weic & & & & \\
\hline & Mix & Fly ash & Bottom ash & river sand & foundry sand & Bentonite & cement \\
\hline 1 & $\mathrm{M}$ & 100 & & & & & 0 \\
\hline 2 & M1C & 99 & & & & & 1 \\
\hline 3 & M3C & 97 & & & & & 3 \\
\hline 4 & $\mathrm{M} 6 \mathrm{C}$ & 94 & & & & & 6 \\
\hline 5 & M5BA & 95 & 5 & & & & 0 \\
\hline 6 & M10BA & 90 & 10 & & & & 0 \\
\hline 7 & M25BA & 75 & 25 & & & & 0 \\
\hline 8 & M50BA & 50 & 50 & & & & 0 \\
\hline 9 & M75BA & 25 & 75 & & & & 0 \\
\hline 10 & M90BA & 10 & 90 & & & & 0 \\
\hline 11 & M2BA3C & 95 & 2 & & & & 3 \\
\hline 12 & M7BA3C & 90 & 7 & & & & 3 \\
\hline 13 & M22BA3C & 75 & 22 & & & & 3 \\
\hline 14 & M47BA3C & 50 & 47 & & & & 3 \\
\hline 15 & M72BA3C & 25 & 72 & & & & 3 \\
\hline 16 & M87BA3C & 10 & 87 & & & & 3 \\
\hline 17 & M5RS & 95 & & 5 & & & 0 \\
\hline 18 & M10RS & 90 & & 10 & & & 0 \\
\hline 19 & M25RS & 75 & & 25 & & & 0 \\
\hline 20 & M50RS & 50 & & 50 & & & 0 \\
\hline 21 & M75RS & 25 & & 75 & & & 0 \\
\hline 22 & M90RS & 10 & & 90 & & & 0 \\
\hline 23 & M2RS3C & 95 & & 2 & & & 3 \\
\hline 24 & M7RS3C & 90 & & 7 & & & 3 \\
\hline 25 & M22RS3C & 75 & & 22 & & & 3 \\
\hline 26 & M47RS3C & 50 & & 47 & & & 3 \\
\hline 27 & M72RS3C & 25 & & 72 & & & 3 \\
\hline 28 & M87RS3C & 10 & & 87 & & & 3 \\
\hline 29 & M5FS & 95 & & & 5 & & 0 \\
\hline 30 & M10FS & 90 & & & 10 & & 0 \\
\hline 31 & M25FS & 75 & & & 25 & & 0 \\
\hline 32 & M50FS & 50 & & & 50 & & 0 \\
\hline 33 & M75FS & 25 & & & 75 & & 0 \\
\hline 34 & M90FS & 10 & & & 90 & & 0 \\
\hline 35 & M2FS3C & 95 & & & 2 & & 3 \\
\hline 36 & M7FS3C & 90 & & & 7 & & 3 \\
\hline 37 & M22FS3C & 75 & & & 22 & & 3 \\
\hline 38 & M47FS3C & 50 & & & 47 & & 3 \\
\hline 39 & M72FS3C & 25 & & & 72 & & 3 \\
\hline 40 & M87FS3C & 10 & & & 87 & & 3 \\
\hline 41 & M1B & 99 & & & & 1 & 0 \\
\hline 42 & M3B & 97 & & & & 3 & 0 \\
\hline 43 & M6B & 94 & & & & 6 & 0 \\
\hline 44 & $\mathrm{M} 10 \mathrm{~B}$ & 90 & & & & 10 & 0 \\
\hline
\end{tabular}


correspond to flow above this value. The mixture was visually judged as water was added. A flow test was conducted when the mixture looked like it would begin to flow. More water would then be added and the consecutive flow tests were conducted. This is similar to the rules followed when performing liquid limit tests. The mixture started off dry and water was gradually added as consecutive tests were completed so that there was never a need for redrying the mixture.

This information yields graphs that can be used to find the water needed for any given spread. Figure 2.3 shows a sample of one of these graphs. In addition, curves can be generated to show the relationship between aggregate content and water content for constant spread as shown in Figure 2.4. Figure 2.4 shows the water content versus percentage of aggregate for all three aggregate mixtures with and without cement for a spread of 9 inch $(23 \mathrm{~cm})$. This spread was chosen because it is between 8 inches $(20 \mathrm{~cm})$ and 12 inches ( $30 \mathrm{~cm}$ ), as recommended by ASTM (ASTM 2000).

Figure 2.3, Figure 2.4 and Table 2.1 also show the naming convention that was adopted for this research. The first letter reflects where the fly ash came from. All of the mixtures start with the letter $\mathrm{M}$ to reflect that they came from MEA. This was used in case it was decided to use fly ash from another location, but in the course of this research only MEA fly ash was used so all mixes will start with the letter M. The next group of numbers and letters describe the percentage of aggregate by dry weight, and the third number and letter combination describe the amount of cement or additives by weight. The labels used are BA for bottom ash, RS for river sand, FS for foundry sand, and C for cement. For instance, the mixture M75BA3C would be $75 \%$ bottom ash, $3 \%$ cement and the remaining $22 \%$ would be MEA fly ash. The mixture M50RS would contain $50 \%$ river sand and the remaining 50\% would be MEA fly ash. This naming convention allows one to easily know what the mixture contains without referring back to this section.

The flow testing clearly shows a trend in that more aggregates will decrease the water demand. However, if the mixture has too much aggregate it will not flow under its own weight. The water will immediately segregate and the remaining pile will not spread to 9 inches $(23 \mathrm{~cm})$. The bottom ash had less of a problem with water segregation than 


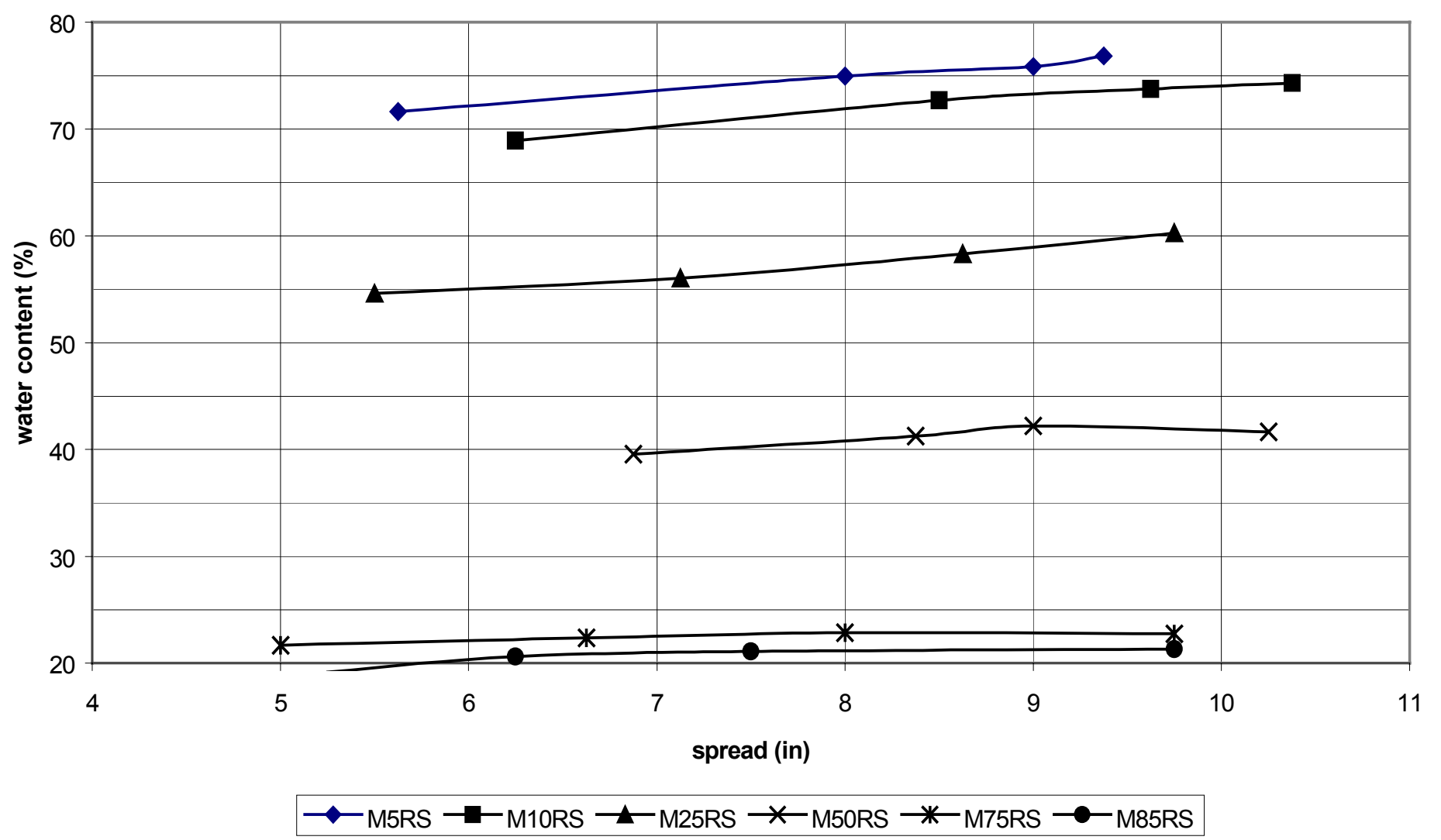

Figure 2.3: Water Content versus Spread for River Sand Mixtures 


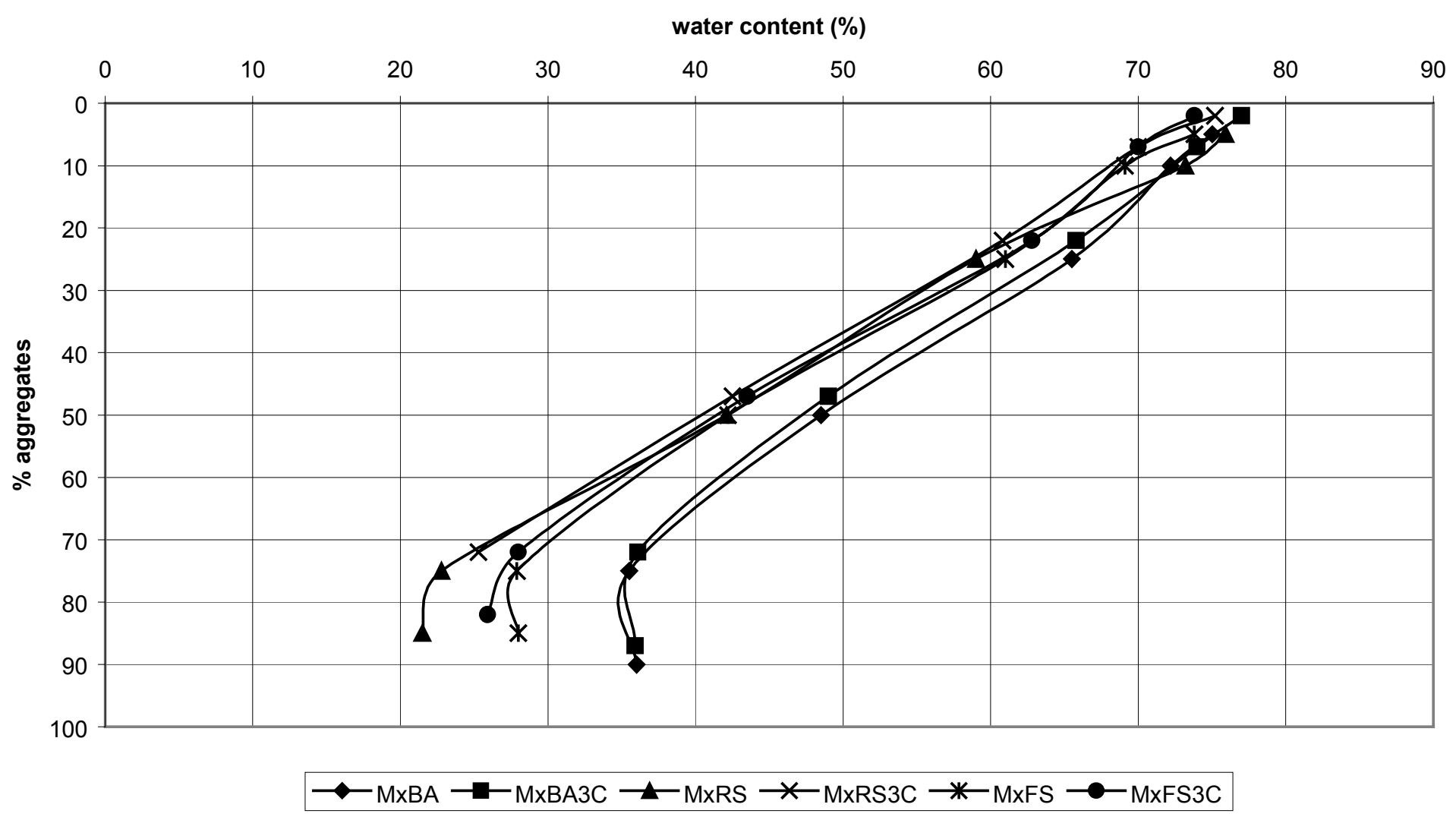

Figure 2.4: Water Content versus Percentage of Aggregate for 9 inch $(23 \mathrm{~cm})$ Spread 
did the two sands. This is why it was possible to test bottom ash at $90 \%$ aggregates while the two sands could only be tested at $85 \%$ aggregates. The flow tests also show a trend for the river sand to require less water than the foundry sand. The foundry sand required less water than the bottom ash. This is because of the particle size distribution of the three aggregates. The river sand is less uniform than the foundries sand so the variety of particle sizes takes up more space and leave less room for the water. The foundry sand is very uniform so it will have more interparticle friction at high aggregate contents, and will need slightly more water to separate the particles and encourage flow. The bottom ash has the highest demand because of the structure of the bottom ash particles. Bottom ash particles are more porous, like a sponge. This porous nature makes the bottom ash mixtures require more water than the sands (Vipulanandan et al. 1998).

\subsection{Strength Testing}

Strength testing for controlled low strength materials is usually done at 28-days. This was the procedure used in earlier days of CLSM when it was lumped in with concrete testing procedures. Concrete mixes have been shown to gain most of their strength at 28-days, but this correlation is not necessarily the same for CLSM. Some quick set CLSM claims to have its full strength in just a couple days, while some other CLSM may have strength gains well past 28-days (Mullarky 1998). Many mixes will meet state requirements for maximum strength at 28-days, but the strength exceeds that requirement several years later (Brinkley 1998). Regardless of the complete suitability of the test standards, the ASTM recommended procedures were followed in this research program.

27 different mixes were originally cast for unconfined compression tests. These tests were done in accordance with ASTM D 4832. Some tests were repeated to insure the accuracy of the information obtained. When it became apparent that none of the original mixtures would qualify for a WVDOT class C CLSM (ultimate 28-day compressive strength above 1,000 psi $(6,895 \mathrm{~Pa})) 15$ additional high strength tests were conducted. All the mixtures are shown in Tables 2.2 and 2.3. Ten cylinders (3 inch (7.6 $\mathrm{cm})$ diameter and 6 inch $(15.2 \mathrm{~cm})$ in height) were cast for each of the 42 mixes. Two cylinders were used for 7, 14, and 28-day strengths and the reported strength for each of 
Table 2.2 Low Compressive Strength Mixtures.

\begin{tabular}{|c|c|c|c|c|c|}
\hline Mixture & Fly Ash & Bottom Ash & River Sand & Foundry Sand & Cement \\
\hline M90BA & $10 \%$ & $90 \%$ & & & \\
\hline M83BA & $17 \%$ & $83 \%$ & & & \\
\hline M75BA & $25 \%$ & $75 \%$ & & & \\
\hline M50BA & $50 \%$ & $50 \%$ & & & \\
\hline M25BA & $75 \%$ & $25 \%$ & & & \\
\hline M10BA & $90 \%$ & $10 \%$ & & & \\
\hline M85RS & $15 \%$ & & $85 \%$ & & \\
\hline M80RS & $20 \%$ & & $80 \%$ & & \\
\hline M75RS & $25 \%$ & & $75 \%$ & & \\
\hline M50RS & $50 \%$ & & $50 \%$ & & \\
\hline M25RS & $75 \%$ & & $25 \%$ & & \\
\hline M10RS & $90 \%$ & & $10 \%$ & & \\
\hline M85FS & $15 \%$ & & & $85 \%$ & \\
\hline M80FS & $20 \%$ & & & $80 \%$ & \\
\hline M75FS & $25 \%$ & & & $75 \%$ & \\
\hline M50FS & $50 \%$ & & & $50 \%$ & \\
\hline M25FS & $75 \%$ & & & $25 \%$ & \\
\hline M10FS & $90 \%$ & & & $10 \%$ & \\
\hline M90BA1C & $9 \%$ & $90 \%$ & & & $1 \%$ \\
\hline M83BA1C & $16 \%$ & $83 \%$ & & & $1 \%$ \\
\hline M75BA1C & $24 \%$ & $75 \%$ & & & $1 \%$ \\
\hline M85RS1C & $14 \%$ & & $85 \%$ & & $1 \%$ \\
\hline M80RS1C & $19 \%$ & & $80 \%$ & & $1 \%$ \\
\hline M75RS1C & $24 \%$ & & $75 \%$ & & $1 \%$ \\
\hline M85FS1C & $14 \%$ & & & $85 \%$ & $1 \%$ \\
\hline M80FS1C & $19 \%$ & & & $80 \%$ & $1 \%$ \\
\hline M75FS1C & $24 \%$ & & & $75 \%$ & $1 \%$ \\
\hline
\end{tabular}


Table 2.3 High Compressive Strength Mixtures.

\begin{tabular}{|l|l|l|l|l|l|}
\hline Mixture & Fly Ash & Bottom Ash & River Sand & Foundry Sand & Cement \\
\hline M40BA2C & $58 \%$ & $40 \%$ & & & $2 \%$ \\
\hline M50BA2C & $48 \%$ & $50 \%$ & & & $2 \%$ \\
\hline M60BA2C & $38 \%$ & $60 \%$ & & & $2 \%$ \\
\hline M70BA2C & $28 \%$ & $70 \%$ & & & $2 \%$ \\
\hline M80BA2C & $18 \%$ & $80 \%$ & & $2 \%$ \\
\hline M40BA3C & $57 \%$ & $40 \%$ & & & $3 \%$ \\
\hline M50BA3C & $47 \%$ & $50 \%$ & & & $3 \%$ \\
\hline M60BA3C & $37 \%$ & $60 \%$ & & $3 \%$ \\
\hline M70BA3C & $27 \%$ & $70 \%$ & & $3 \%$ \\
\hline M80BA3C & $17 \%$ & $80 \%$ & & & $3 \%$ \\
\hline M40BA4C & $56 \%$ & $40 \%$ & & & $4 \%$ \\
\hline M50BA4C & $46 \%$ & $50 \%$ & & & $4 \%$ \\
\hline M60BA4C & $36 \%$ & $60 \%$ & & & $4 \%$ \\
\hline M70BA4C & $26 \%$ & $70 \%$ & & & 4 \\
\hline M80BA4C & $16 \%$ & $80 \%$ & & & 4 \\
\hline
\end{tabular}


these tests is the average of these two compressive strengths. More cylinders were made than required so that defective cylinders, such as the ones that break during the process of removal from the plastic cylindrical molds, do not have to be used.

The cylinders were prepared by measuring all of the dry ingredients into a container and gradually adding the required amount of water to achieve 9 inch $(23 \mathrm{~cm})$ spread. The mixture would be mixed with a trowel until it was completely mixed and then the flowability would be measured to verify that it had 9 inch $(23 \mathrm{~cm})$ spread. Pouring the mixture with a large ladle, with no vibration or tamping all ten cylinders were filled. The plastic molds were all coated with a thin layer of oil on the inside to prevent the mixture from sticking to the walls during pouring and to make the removal at 7 days easier. The cylinders were stored in a controlled $100 \%$ humidity room and all cylinders were stripped of their plastic molds after 7 days of curing.

One problem that has been noted with fly ash cylinders is that the bottom of the cylinder will have crumbled edges. This makes the area of contact reduced in the compression testing. The thin coat of oil helps to reduce this damage but some edge crumbling still occurs. To overcome this, a piece of Celotex, which is a rigid foam used for insulating houses, was placed on each side of the cylinders before crushing. This foam effectively fills in the parts that have crumbled by deforming to the exact shape of the fly ash cylinder. The foam completely deforms at $35 \mathrm{psi}(240 \mathrm{~Pa})$ so it will not effect the ultimate strength of the samples. This capping method is in accordance with ASTM C 1231, which recommends using elastomeric pads for capping partially crumbled cylinders (ASTM 2000). The only drawback to using the foam is that a stress-strain curve cannot be accurately constructed, but by measuring the samples after they had reached their ultimate stress it was found that the samples undergo an average of about $2 \%$ strain before failure.

All tests were done on a Wykeham Farrance compression test machine with calibrated load rings to measure the load. Two load rings were used to accommodate the wide range of ultimate loads. The cylinders were removed from the humidity room eight hours before testing, then the average height and width were measured. The cylinders were placed in the compression machine with the Celotex on top and bottom. The load was increased up to $35 \mathrm{psi}(240 \mathrm{~Pa})$ to seat the cylinder into the Celotex pads. This 
seating load was then released and measures were taken to insure that the cylinder was straight. The strain rate was set at $2 \%$ per minute and the cylinder was loaded until failure. The compressive strength is the maximum load divided by the cross sectional area. All of the values recorded can be found in appendix B.

The compression testing results show different trends for the mixes. The bottom ash was clearly the strongest mixture. It was stated earlier that a higher strength material can sometimes be desired and it appears that the bottom ash mixtures are the only mixtures that will exceed the WVDOT class $\mathrm{C}$ limit of $1,000 \mathrm{psi}(6,895 \mathrm{~Pa})$ without adding large amounts of cement. The bottom ash had the widest distribution of particles and it is believed that this helped it to form a better matrix and therefore had the highest strengths. Both of the sands were uniformly graded and had similar performances. One interesting feature was that the bottom ash formed a bell shape curve when 28-day strength was compared to the percentage aggregate. This supports the idea that the larger particle distribution forms a good matrix. Just like in concrete mixtures, a strong composite needs both small and large aggregates as well as the finer binding agents. This combination of sizes allows the particles to nestle among each other and form a stronger composite. Moreover, the bottom ash contains some $\mathrm{CaO}$ that contributes to the pozzolanic activity of the mixes.

Both of the sands make good candidates for WVDOT Class A or Class B CLSM mixtures since their strengths did not exceed $300 \mathrm{psi}(2,070 \mathrm{~Pa})$ in any of the cases. Both of the sands had strengths that were in the $200 \mathrm{psi}(1,380 \mathrm{~Pa})$ range for all mixtures with one exception. The strength of the two mixtures containing $85 \%$ sand dropped significantly to the $100 \mathrm{psi}(690 \mathrm{~Pa})$ range. The sand mixtures also formed bell shaped curves that peaked between $50 \%$ and $75 \%$ aggregates; however, these results are less significant because of the small range of values for compressive strengths in these mixtures.

The mixtures containing only bottom ash and fly ash showed the highest strengths in the range of $50 \%$ to $75 \%$ of bottom ash. Only one original sample (M75BA1C) exceeded 1,000 psi $(6,890 \mathrm{~Pa})$ compressive strength but not all four samples exceeded this limit. For this reason, higher strength testing was conducted on bottom ash mixtures with varying bottom ash contents of $40 \%$ to $80 \%$. These tests were performed on 
mixtures with up to $4 \%$ cement so that the effects of varying cement content could be analyzed. These mixtures resulted in some very high strength samples. The final two tests, $70 \%$ and $80 \%$ bottom ash with $4 \%$ cement, had to be tested on a different compression machine because their strengths exceeded the mechanical limits of the load rings for the Wykeham Farrance compression machine. Figure 2.8 shows the influence of cement content on strength values of bottom ash mixtures. The peak strength occurred when the bottom ash content was about $70 \%$ for all of the tests.

There is however some discrepancies in the data. The line representing 3\% cement was consistently slightly below the line representing $2 \%$ cement. This was caused by an experimental error. The batch with 3\% cement appeared to have air-entrained cement rather than normal type I cement. The data still shows the expected shape of the curve, however the values are slightly reduced. In addition, the data point that corresponds to M70BA4C was the last sample to be tested on the Wykeham Farrance compression machine. It was stated that these samples were too strong to be accurately tested on this machine so there were no reliable results for M70BA4C. The data point shown in Figure 2.8 was found by a best-fit method. The samples with $60 \%, 70 \%$, and $80 \%$ bottom ash and $4 \%$ cement were tested again at 35 days to validate the data that was obtained on the Wykeham Farrance machine at 28 days. Comparing the four graphs made from the strength testing at 7, 14, 28 and 35 days to each other, the value for the 28 day strength of M70BA4C was estimated. It should be noted that the point shown on the graph represents this estimated number.

The samples that were chosen for repeat tests had points that did not fall in the expected range. They were repeated under the same conditions as the original samples. The new values were computed by averaging all four values, the two original values and the two new values. The graphs presented in the body of this report represent the corrected data. All of the original data is presented in the appendices. Figures 2.5, 2.6, and 2.7 show the strength characteristics of the river sand, foundry sand, and bottom ash mixtures that did not contain cement, respectively.

Compressive strength tests were also conducted on saturated CLSM cylinders. These tests were conducted to find the influence of water saturation on the final compressive strength. The samples were prepared by the same methods discussed before. 


\section{Strength vs. Percentage of River Sand}

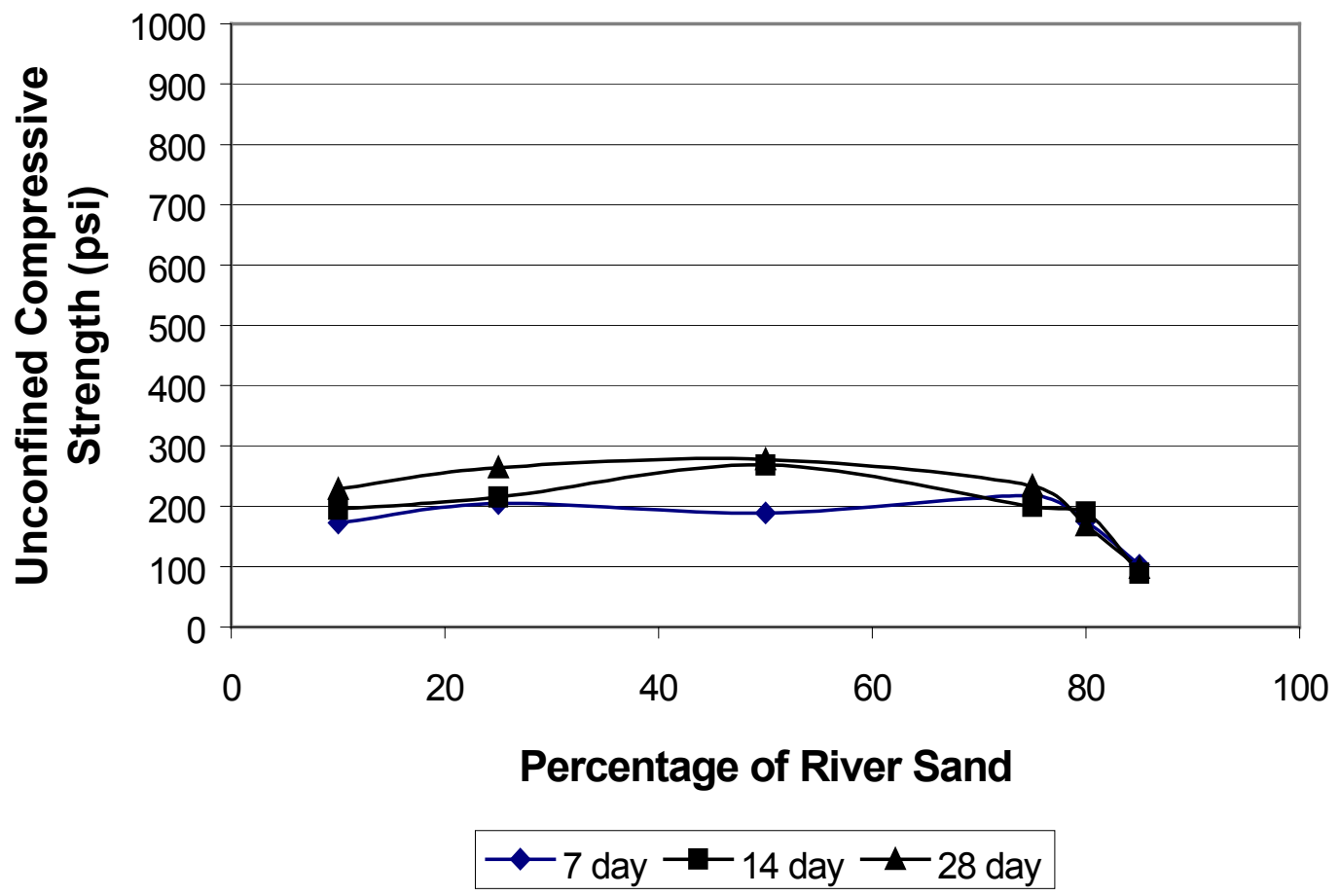

Figure 2.5: Strength Curves for River Sand Mixtures 
Strength vs. Percentage of Foundry Sand

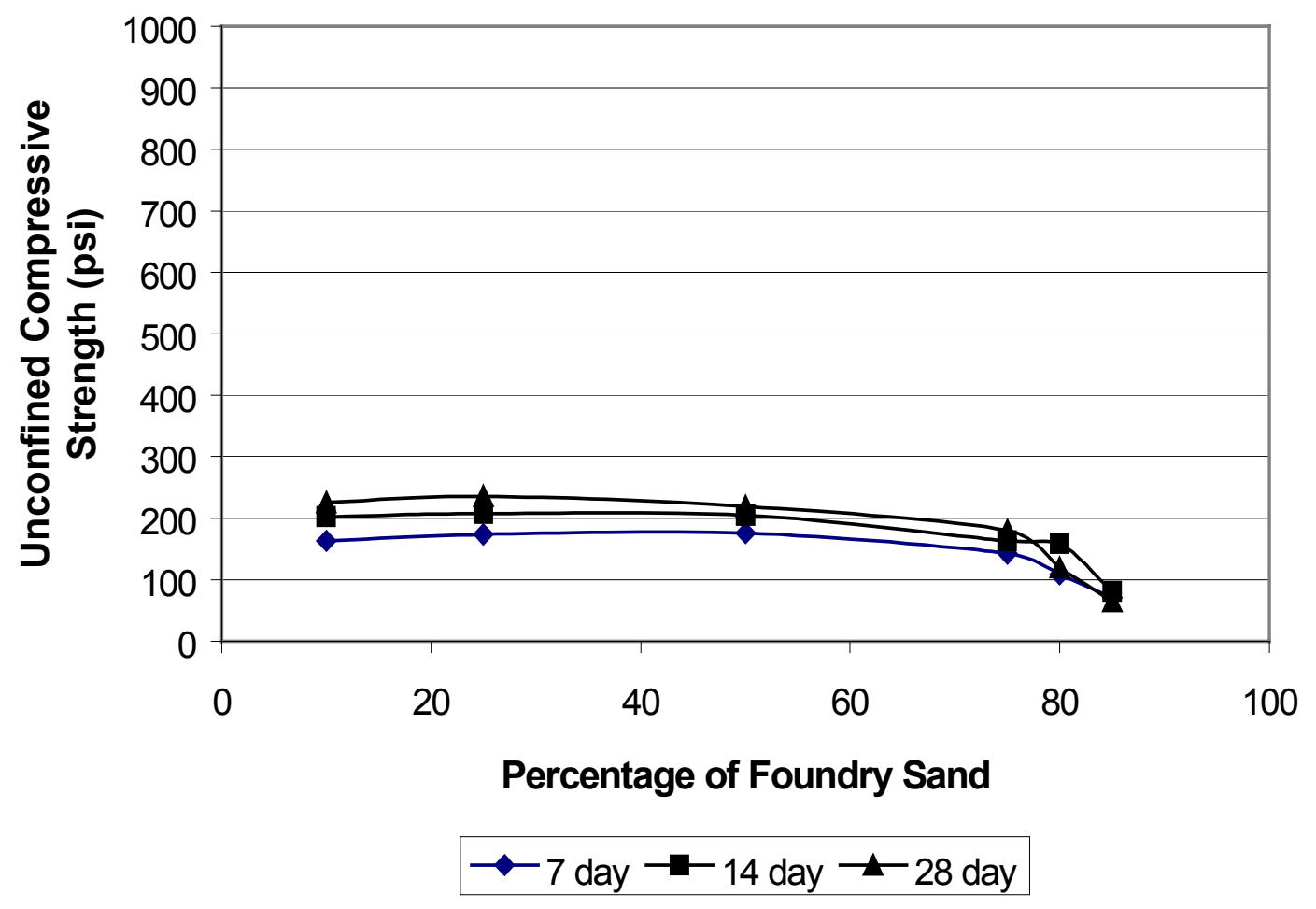

Figure 2.6: Strength Curves for Foundry Sand Mixtures 
Strength vs. Percentage of Bottom Ash

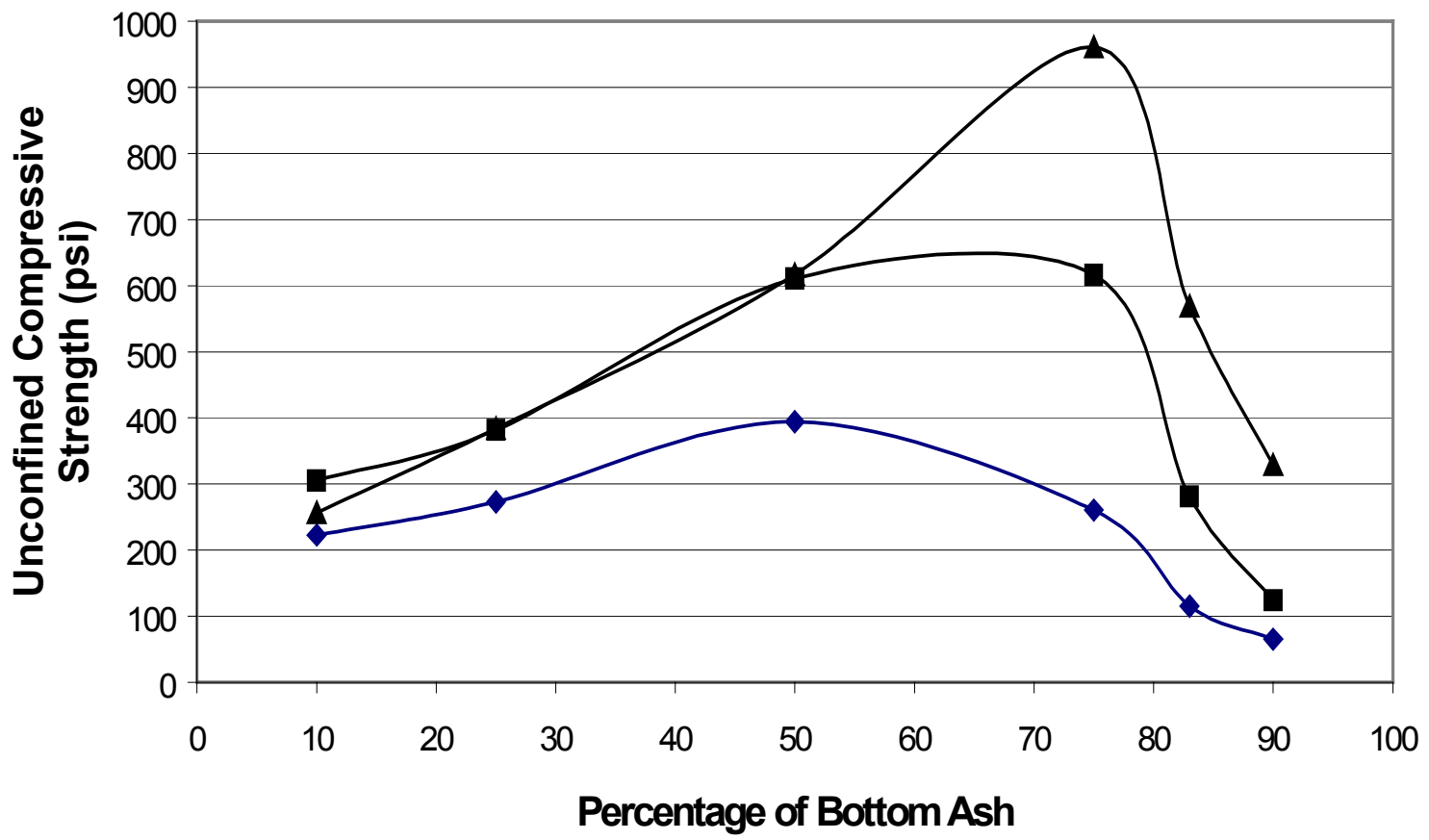

$\neg-7$ day $\rightarrow-14$ day $\rightarrow-28$ day

Figure 2.7: Strength Curves for Bottom Ash Mixtures 
28-Day Strength of BottomAsh Mixtures

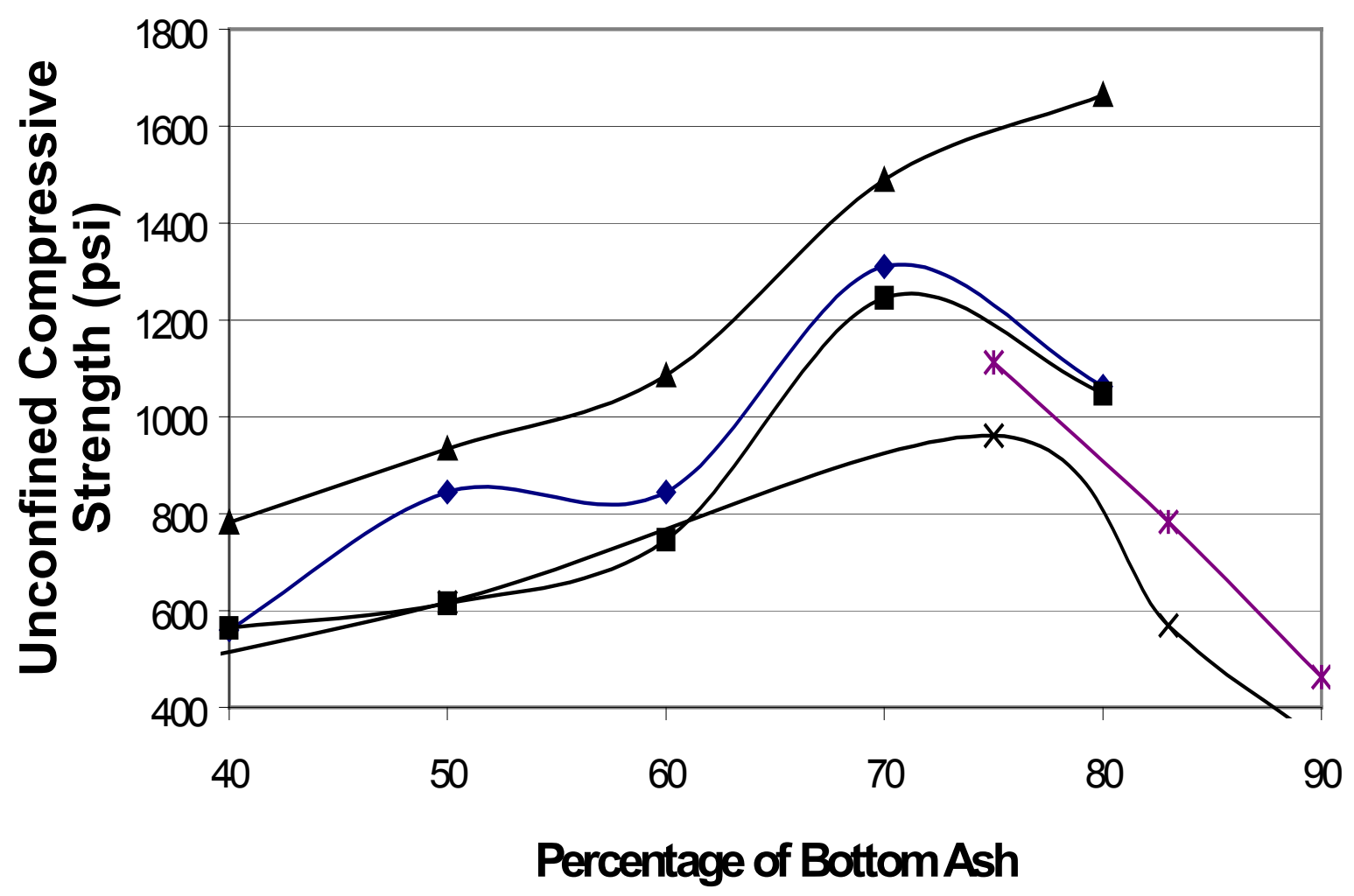

$\rightarrow 0 \%$ cement $\rightarrow-1 \%$ cement $\rightarrow-2 \%$ cement $\rightarrow-3 \%$ cement $\rightarrow-4 \%$ cement

Figure 2.8: 28-Day Strength Curves for Bottom Ash and Cement Mixtures 
However, after 7 days when the samples were removed from the plastic molds, the samples were submerged in water. The samples remained submerged in water for 21 days. The 28-day compressive strength was recorded and compared to the regular, unsaturated, value. These tests showed that the compressive strength decreased as much as $20 \%$ due to saturation. The mixtures containing Foundry sand had the most reduction in strength, particularly samples with a high percentage of foundry sand in the mixture. The bottom ash mixtures had the least reduction in strength. Some of the bottom ash mixtures only had strength reductions of $12 \%$. A limited number of tests were conducted to investigate the influence of water saturation. These tests show that the compressive strength of CLSM mixtures reduced by $12 \%$ to $20 \%$ when the mixtures were cured in saturated conditions.

\subsection{PENETRATION RESISTANCE}

In addition to the compressive strength tests, penetration resistance tests were also performed. The penetration resistance is a test recommended by ASTM but is not mentioned in the WVDOT specification book. These tests were performed in accordance with ASTM C 403 which requires that the material be put into a container that is at least 6 inches square by 9 inches deep (15 $\mathrm{cm}$ square by $23 \mathrm{~cm}$ deep). The material was kept for 14 days in a humidity room before conducting any tests. This research also included tests performed during the first 24 hours to get a better understanding of how the material hardens. The tests were conducted with a Humboldt spring-loaded penetrometer with a maximum reading of $110 \mathrm{lb}(490 \mathrm{~N})$ and head sizes varying from $1 \mathrm{in}^{2}$ to $1 / 40 \mathrm{in}^{2}(6.5$ $\mathrm{cm}^{2}$ to $0.004 \mathrm{~cm}^{2}$ ). This means that the penetrometer can determine a maximum penetration resistance of 4,400 psi $(30.3 \mathrm{kPa})$. Most of the samples exceeded the maximum penetration resistance so it is difficult to draw any conclusions on their hardening characteristics from these tests.

All of the samples that were tested for compressive strength were also tested for penetration resistance. Figure 2.9 shows all of the results measured at 24 hours for the penetration resistance testing. The penetration resistance tests show that the bottom ash tends to have the highest $24 \mathrm{hr}$ strength, while the foundry sand tends to have the lowest $24 \mathrm{hr}$ strength. This is related to the gradation of each material. The bottom ash has a 
better distribution of aggregate sizes than do the sands. This allows the material to have a better matrix and increased strength. The bottom ash also has a higher percentage of large aggregates that would assist in the removal of bleed water. The river sand has some variation in size so it too can form a quality matrix and the presence of large particles helps the bleed water leave the sample. The foundry sand had consistently lower strength because of the uniform particle size. It does not form a good matrix and there are no large particles to allow the escape of the bleed water. The data collected during the penetration resistance tests can be found at the end of appendix B. 
Penetration Resistance at $\mathbf{2 4}$ hours

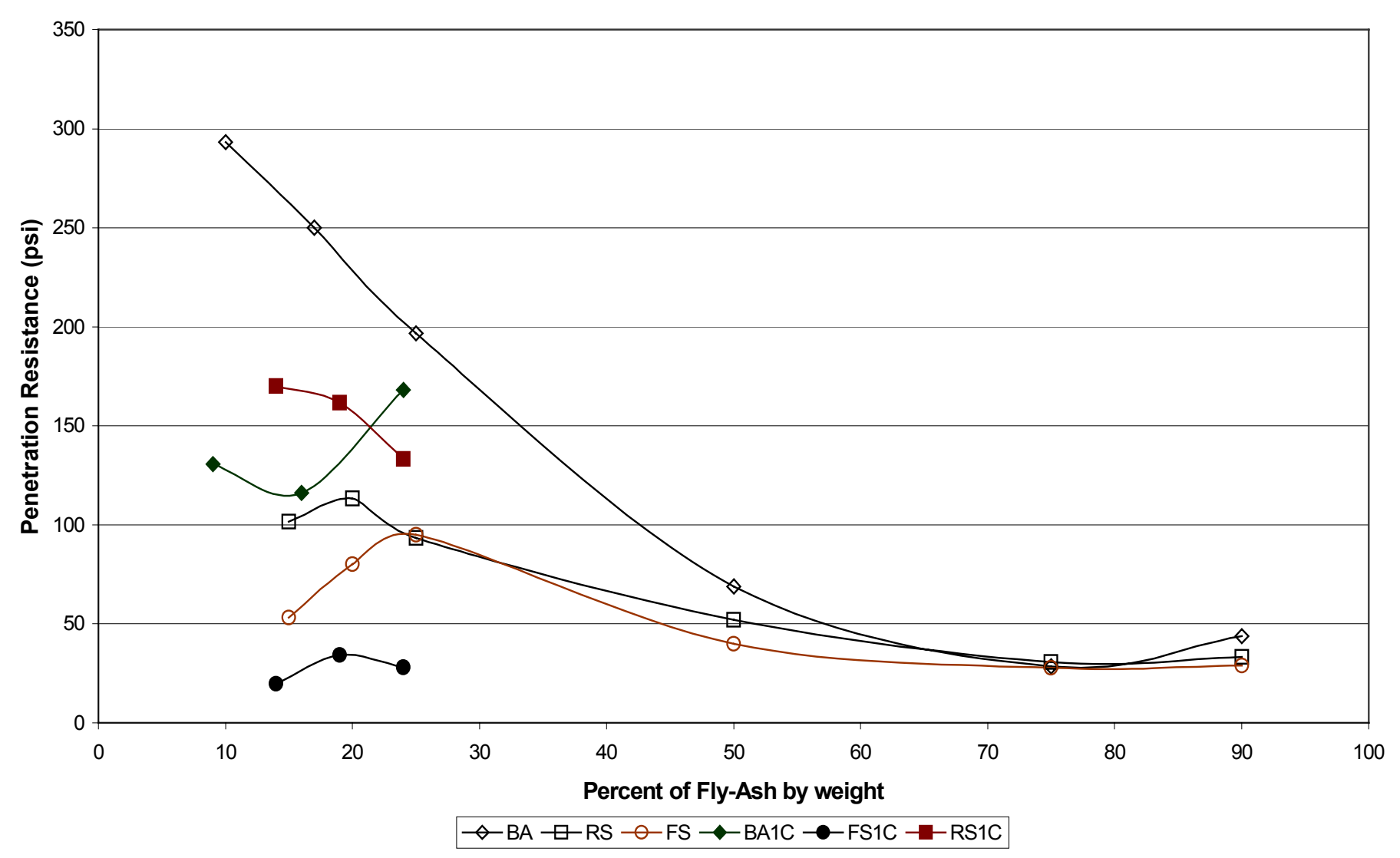

Figure 2.9: Penetration Resistance Testing Results 


\section{CHAPTER 3}

\section{DESIGN OF THE PIPE TESTING APPARATUS}

In this chapter, the design of the pipe testing apparatus is discussed. This discussion includes the specific goals of the testing apparatus, the structural design, and the data acquisition system. Some figures and calculations are presented in the body of this chapter. Appendix D contains all the figures and calculations that were performed during the structural analysis of the pipe testing apparatus.

\subsection{SPECIFIC GOALS OF THE PIPE TESTING APPARATUS}

The pipe testing apparatus should have the capability to test several different sizes of pipe in a controlled environment. The device should be able to test trench widths up to 3 times the diameter of the pipe. The testing device should be able to apply a uniform surcharge load and measure the deflections in the pipe and the stresses in the soil mass.

To accommodate available deflectometers, the minimum diameter of pipe needed to be 6 inches $(15 \mathrm{~cm})$. Therefore, the objective was to test flexible pipes with diameters of 6 inches $(15 \mathrm{~cm})$ and 8 inches $(20 \mathrm{~cm})$. To test a trench width of three times the 8 inch $(20 \mathrm{~cm})$ diameter pipe the box needed to be at least 24 inches $(60 \mathrm{~cm})$ wide. The box also needed to be at least 18 inches $(46 \mathrm{~cm})$ deep to provide 2 inches $(5 \mathrm{~cm})$ bedding, and one pipe diameter cover. The size of the test box was chosen as 40 inch long by 25 inch wide by 20 inch deep (102 cm (L) x $64 \mathrm{~cm}(\mathrm{~W})$ x $51 \mathrm{~cm}(\mathrm{D}))$.

The next step was to devise a method for application of uniform surcharge loading on the buried pipe. Many companies make inflatable jacks that are shaped like large pillows and can be used with air pressure or water pressure. As an alternative to this, motorcycle inner tubes were considered. Motorcycle inner tubes are designed for pressures of at least $60 \mathrm{psi}(412 \mathrm{~Pa})$ and come in a variety of sizes. Inner tubes for a 16 inch $(41 \mathrm{~cm})$ diameter 6 inch $(15 \mathrm{~cm})$ wide tire were chosen. When this tire tube is folded flat, it has the shape of a rectangle 6 inches $(15 \mathrm{~cm})$ wide and 25 inches $(64 \mathrm{~cm})$ long with the stem sticking straight up. For a 16 inch $(41 \mathrm{~cm})$ diameter tube, 25 inches $(64 \mathrm{~cm})$ is one half of the circumference. Eight of these tubes folded flat and laid side by side occupies a space that is 40 inch $(102 \mathrm{~cm})$ by $25 \mathrm{inch}(64 \mathrm{~cm})$. The final height of the test 
box was chosen as 20 inches $(51 \mathrm{~cm})$ to allow some room for the inflation of the inner tubes.

The last stipulation for the design of the test box was that the interior should be smooth to prevent any frictional losses and the deflections of the test box should be kept to a minimum level. The interior of the box consisted of smooth 1/8 inch $(3.2 \mathrm{~mm})$ steel plates welded together in the corners. A reaction frame was installed to apply direct loading over the center of the test box. The following sections provide details of the design of the test box.

\subsection{STRUCTURAL DESIGN OF THE PIPE TESTING APPARATUS}

The goal in the design of the testing apparatus was to hold a sufficient volume of soil to bury and surround corrugated pipe for testing the soil-pipe interactions under surcharge loading. The surface loading applied to the soil acts as a simulation of surcharge stress. In addition, a cross beam was designed for the application of a direct loading that simulates a wheel load or other point loads that might be applied above the pipe. The testing apparatus designed is a steel box with the inside dimensions of 40 inch (L) x 25 inch (W) x 20 inch (D) (102 cm (L) x $64 \mathrm{~cm}$ (W) x $51 \mathrm{~cm}$ (D)). The box is fully reinforced so that the deflections of the box are negligible in relation to the deflections of the pipe. Although the box was only expected to reach $32 \mathrm{psi}(220 \mathrm{~Pa}$ ) during the coarse of this research, it was designed for $70 \mathrm{psi}(480 \mathrm{~Pa})$ for potential future use.

\subsubsection{REQUIREMENTS FOR OPERATING PRESSURE OF 70 psi (480 Pa)}

(i) Design of the Reinforcing Bars

For ease of construction, the box is made from $1 / 8$ " steel plates with three steel angles welded to each side to prevent deflections. Each angle can be modeled as a fixedfixed beam with a continuous load across it. The equation for the maximum deflection in a fixed-fixed beam with continuous loading is given as (PCI 1999):

$$
\mathrm{y}=5(\mathrm{~W})\left(\mathrm{L}^{4}\right) /(384 \mathrm{EI})
$$

In this equation $\mathrm{y}$ is the maximum deflection, $\mathrm{W}$ is the load per length, $\mathrm{L}$ is the length of the member, E is Young's modulus, and I is the moment of inertia. For a minimum 
allowable deflection of 0.01 inch $(0.25 \mathrm{~mm})$, the minimum required moment of inertia for the supporting members can be calculated as:

$$
\mathrm{I}=\left(8.98 \times 10^{-5}\right)(\mathrm{W})\left(\mathrm{L}^{4}\right)
$$

In this equation a value of 29,000 ksi (200 MPa) for Young's Modulus was assumed. Using this equation, the required moment of inertia could be calculated for each side of the pipe testing apparatus. Based on the calculations for I, the following support members were chosen. The lid and the 25 inch $(64 \mathrm{~cm})$ side were supported by $1 / 4$ inch $(6.4 \mathrm{~mm})$ thick steel angles with legs that measure 3 inches $(7.6 \mathrm{~cm})$ each. The lid was supported by 8 of the 3 inch $(7.6 \mathrm{~cm})$ steel angles and the 25 inch $(64 \mathrm{~cm})$ sides were supported with 3 of the 3 inch $(7.6 \mathrm{~cm})$ steel angles on each side. The 40 inch $(102 \mathrm{~cm})$ side was supported with $1 / 4$ inch thick steel angles with legs that measure 6 inches $(15.2 \mathrm{~cm})$ and 3.5 inches $(8.9 \mathrm{~cm})$. The 40 inch $(102 \mathrm{~cm})$ side used 3 of the 6 inch $(15.2 \mathrm{~cm})$ steel angles on each side. The bottom of the box was supported with some 3 inch $(7.6 \mathrm{~cm})$ angles and some 6 inch $(15.2 \mathrm{~cm})$ angles. The structural support for the bottom of the box is in excess of the calculated requirements. The feet on the box, which are 6 inch $(15.2 \mathrm{~cm})$ steel angles provide this excess reinforcement. The deflections that will result from these supports can be found by substituting the known moments of inertia in Equation 3.1. The maximum possible deflections at an operating pressure of 70 psi $(480 \mathrm{~Pa})$ can be calculated as 0.0091 inch $(0.23 \mathrm{~mm})$ on the 40 inch $(102 \mathrm{~cm})$ long side and 0.0098 inch $(0.25 \mathrm{~mm})$ on the 25 inch $(64 \mathrm{~cm})$ wide side. The supporting calculations can be found in appendix A. Figure 3.1 is a schematic of the pipe testing apparatus.

\section{(ii) Design of the Lid Fasteners}

The lid is held down by 20 steel bolts of $1 / 2$ inch $(12.7 \mathrm{~mm})$ diameter with a manufacturer specified yield stress of 70,000 psi (480 kPa). It is a common conservative practice to use a design stress that is (2/3) of the yield stress (Kassimali 1995).

The equation for the average stress in a bolt is given as (Hibbeler 1997):

$$
\sigma=(\mathrm{P})(\mathrm{FS}) /(\mathrm{A})(\mathrm{N})
$$

Where $\sigma$ is the average stress, $\mathrm{P}$ is the load, FS is the factor of safety, A is the cross sectional area of each bolt, and $\mathrm{N}$ is the number of bolts. The factor of safety against the bolts failing at $70 \mathrm{psi}(480 \mathrm{~Pa})$ can be calculated as: 


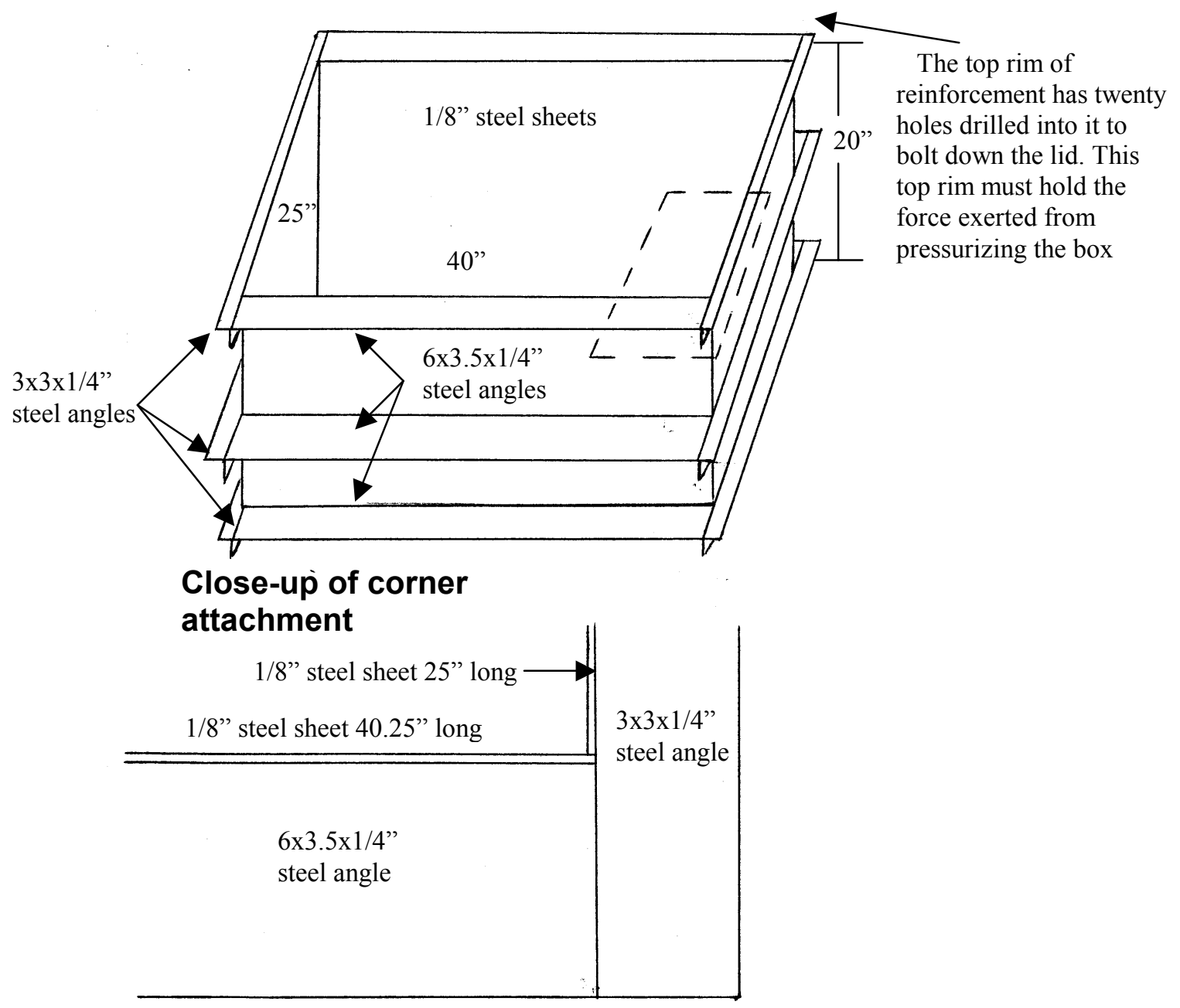

Figure 3.1: Schematic of the Testing Apparatus without the Reaction Frame 


$$
\mathrm{FS}=\sigma_{\text {design }}(\mathrm{A})(\mathrm{N}) /(70 \mathrm{psi})(40 \mathrm{in} \times 25 \mathrm{in})
$$

The factor of safety against failure for the lid bolts is computed as 2.62. The bolts should also be replaced on a regular schedule to insure that they will not fail due to fatigue.

\section{(iii) Weld Strength}

Figure 3.2 illustrates several portions of the box that are potentially subject to failure of the welds. All the interior seams are welded together with continuous welds. These welds could potentially fail. In addition, the top rim of steel angles serves two purposes. The first is as reinforcement against deflections and the second is as the anchor

point for the lid. The lid is bolted to the top rim during operation. Separation of the welds holding down the top rim is a potential failure mode. The free body diagram for the top rim is included in Figure 3.2. The equation for weld strength is given as (Lincoln 1973):

$$
\sigma_{\text {weld }}=0.3 \sigma_{\text {tension }} 0.707 \omega
$$

This specifies the strength of weld per unit length of weld, where $\omega$ is the leg width of the members being welded, and $\sigma_{\text {tension }}$ is the tensile strength of the weld material. The following values of weld strength were calculated using equation 3.5.

$$
\begin{array}{ll}
\sigma_{\text {weld }}=3180 \mathrm{lb} / \text { in } & \text { for } 1 / 4 \text { inch }(6.4 \mathrm{~mm}) \text { welds } \\
\sigma_{\text {weld }}=1590 \mathrm{lb} / \text { in } & \text { for } 1 / 8 \text { inch }(3.2 \mathrm{~mm}) \text { welds }
\end{array}
$$

The four sides and the bottom of the box have continuous $1 / 8$ inch $(3.2 \mathrm{~mm})$ welds. Figure 3.2 shows the geometry of each potential failure. The force $(\mathrm{P})$ acting on the 40 inch (102 $\mathrm{cm})$ side, 25 inch $(64 \mathrm{~cm})$ side, and bottom are: $56 \mathrm{~K}(249 \mathrm{kN}), 35 \mathrm{~K}(156 \mathrm{kN})$, and $70 \mathrm{~K}$ $(311 \mathrm{kN})$, respectively. The total weld length $(\mathrm{L})$ for the 40 inch $(102 \mathrm{~cm})$ side, 25 inch $(64 \mathrm{~cm})$ side, and bottom are 80 inch $(203 \mathrm{~cm}), 65$ inch $(165 \mathrm{~cm})$, and 130 inch $(330 \mathrm{~cm})$, respectively. These values are illustrated in Figure 3.2. Using the following equation, the factor of safety against weld failure can be calculated (Lincoln 1973). The summation sign is used because the 40 inch $(102 \mathrm{~cm})$ side and the 25 inch $(64 \mathrm{~cm})$ side both have an additional 24 inches $(61 \mathrm{~cm})$ of $1 / 4$ inch $(6.4 \mathrm{~mm})$ weld from the reinforcing bars that prevents their separation.

$$
\mathrm{FS}=\Sigma \sigma_{\text {weld }} * \mathrm{~L} / \mathrm{P}
$$


40 Inch Sides

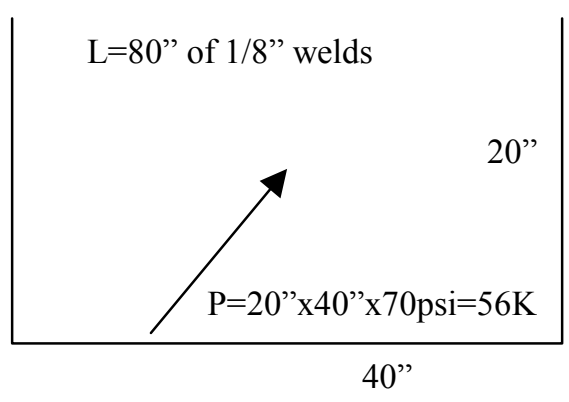

25 Inch Sides

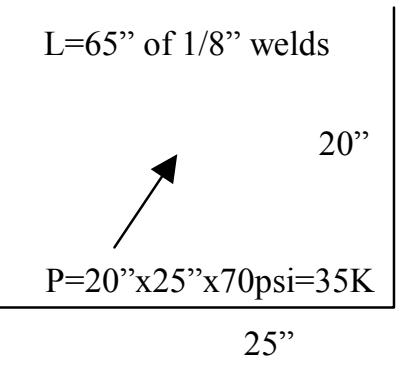

$\underline{\text { Bottom }}$

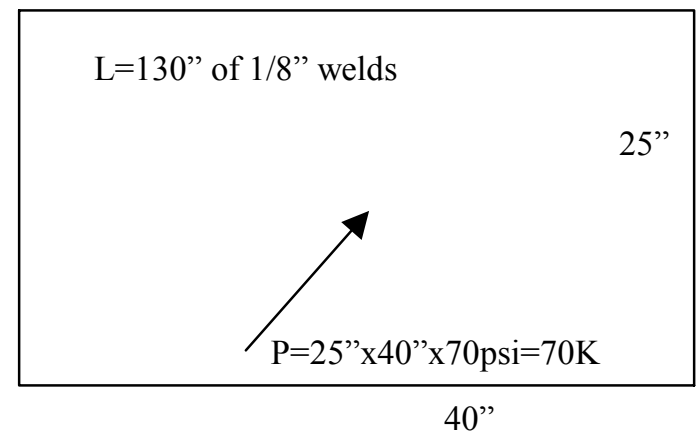

$\underline{\text { Top Rim of Reinforcement }}$ Load transferred from bolts

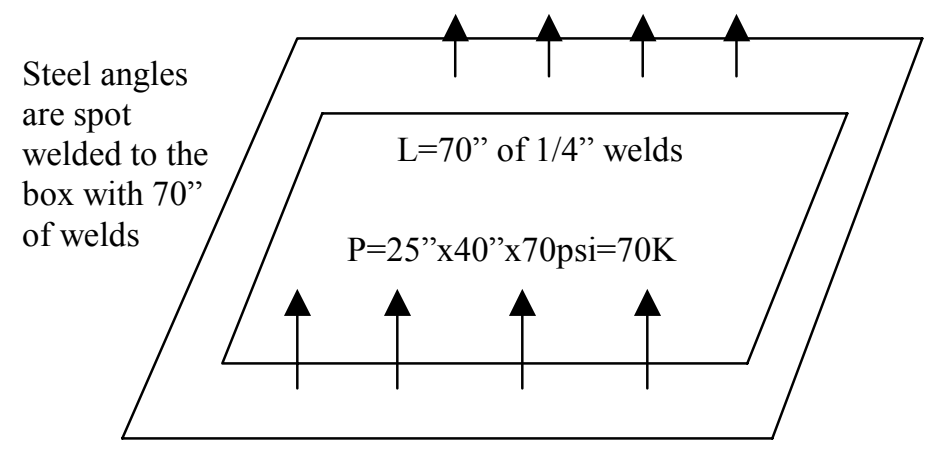

Load is transferred to the top rim through the bolts that hold down the lid

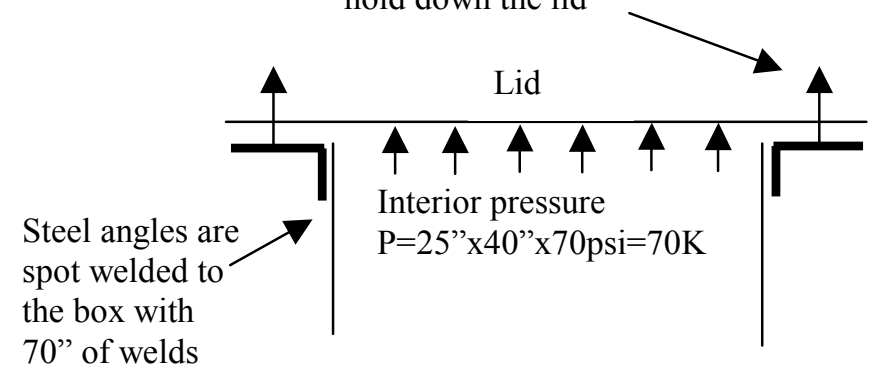

Figure 3.2: Geometry of Welded Areas 
This makes the minimum factor of safety against failure of the welds to be 2.95 , which occurs along the bottom plate. The factor of safety for the top rim being pulled from the box can be found using the same equation. This top rim has 70 inches $(178 \mathrm{~cm})$ of $1 / 4$ inch $(6.4 \mathrm{~cm})$ weld which results in a factor of safety of 3.18 when the box is pressurized to 70 psi (480 Pa).

\subsubsection{REQUIREMENTS FOR OPERATING PRESSURE OF 30 psi (207 Pa)}

It was stated that the actual maximum operational pressure in the experimental procedures is $30 \mathrm{psi}(207 \mathrm{~Pa})$. This means that the actual operational deflections and factors of safety are much more conservative than those shown in section 3.2.1. The operational factors of safety and deflections for the experimental procedure are:

$\mathrm{y}(40$ inch side $)=0.004$ inch $(0.10 \mathrm{~mm})$

$\mathrm{y}(25$ inch side $)=0.004$ inch $(0.10 \mathrm{~mm})$

FS (lid bolts) $=5.72$

FS (welds on 25 inch $(64 \mathrm{~cm})$ side $)=11.22$

FS (welds on 40 inch $(102 \mathrm{~cm})$ side $)=7.94$

FS (welds on the bottom) $=6.45$

FS (separation of top rim) $=6.96$

\subsubsection{DESIGN OF THE REACTION FRAME}

The reaction frame has four major reactions that need to be accounted for: the vertical deflection of the loading beam, the force in all of the bolts, the shear forces in the steel around the bolts, and the possible moment that can result from an off-centered placement of the load. These are considered in the following section. Figure 3.3 shows the geometry of the reaction frame.

(i) Vertical Deflections of the Loading Beam

The deflection of the loading beam can be found by modeling it as a pin-pin beam with a center load. The maximum deflection is given as (Kassimali 1995):

$\mathrm{y}=(\mathrm{P})\left(\mathrm{L}^{3}\right) / 48 \mathrm{EI}$

(Eq. 3.7) 


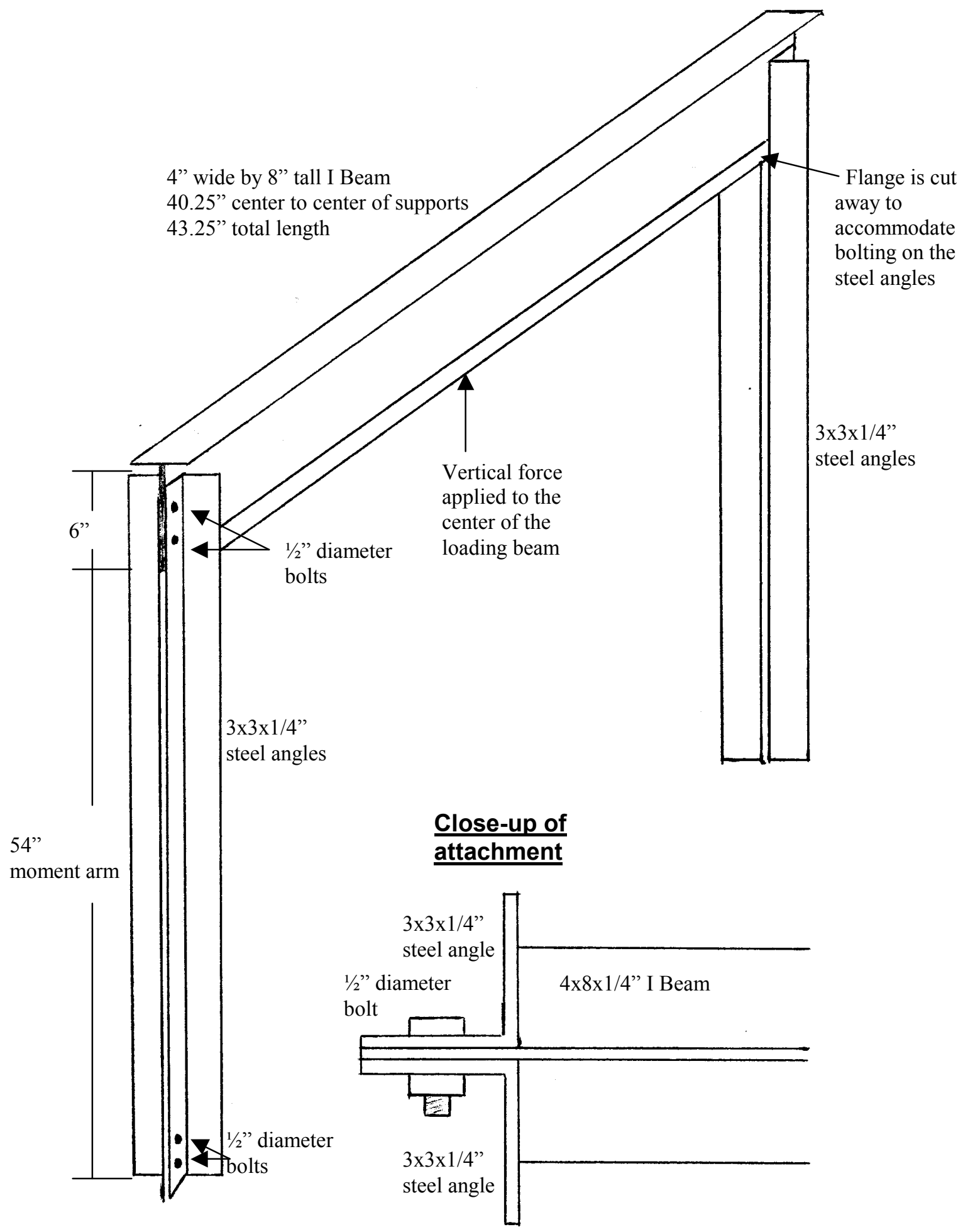

Figure 3.3 Schematic of the Reaction Frame 
In this equation, $\mathrm{P}$ is the point load and the other variables have been previously defined. For a maximum deflection of 0.05 inch $(1.3 \mathrm{~mm})$ and a maximum load of $10,000 \mathrm{lb}$ $(44,500 \mathrm{~N})$, the 40.25 inch $(102.2 \mathrm{~cm})$ long beam will need a minimum moment of inertia of $23.9 \mathrm{in}^{4}\left(994 \mathrm{~cm}^{4}\right)$. An I-beam 4 inches $(10 \mathrm{~cm})$ wide by 8 inches $(20 \mathrm{~cm})$ tall with a moment of inertia of $38.8 \mathrm{in}^{4}\left(1614 \mathrm{~cm}^{4}\right)$ was ussed. Substituting the moment of inertia back into Equation 3.7 will result in a vertical deflection of 0.031 inch $(0.79 \mathrm{~mm})$. This level of deflection is justifiable because no deflection measurements will be taken near the loading beam.

(ii) Bolts on the Reaction Frame

The bolts used were $1 / 2$ inch $(12.7 \mathrm{~mm})$ bolts with $70,000 \mathrm{psi}(483 \mathrm{kPa})$ yield strength. As shown in Figure 3.3, there are four bolts at top of the vertical legs and four bolts at bottom of the vertical legs. Each bolt must hold 2,500 lb $(11,120 \mathrm{~N})$ in a double shear configuration. The following equations can be used to calculate the factor of safety against bolt failure (Hibbeler 1997):

$$
\begin{aligned}
& \sigma_{\text {shear }}=0.5 \sigma_{\text {design }} \\
& \sigma=\mathrm{P} / 2 \mathrm{~A} \\
& \mathrm{FS}=\sigma_{\text {shear }} / \sigma
\end{aligned}
$$

As done before, $\sigma_{\text {design }}$ equal to $(2 / 3)$ of the yield strength was used. Equation 3.10 results in a factor of safety of 3.67 for the bolts on the reaction frame.

(iii) Shear Forces in the Reaction Frame

The shear forces in the steel members supporting the bolts can be calculated by considering the possible failure surface and the resulting area that will be under shear. The load beam must carry the whole 2,500 $\mathrm{lb}(11,120 \mathrm{~N})$ from each bolt and the potential failure surfaces would be small rectangular blocks above each bolt. This block has 2 sides with a height of 2 inch $(5.1 \mathrm{~cm})$ (the bolt spacing) and a width of $1 / 4$ inch $(6.4 \mathrm{~mm})$ (the thickness of the steel members). Figures that show the geometry of these potential shear failures are in appendix D. Equation 3.9 shows the force divided by two times the area because the bolts are in double shear. The shear in the web is not in double shear so Equation 3.11 is used to calculate the shear stress in the web. The area of the potential 
failure surface is calculated by using Equation 3.12. Equations 3.8 and 3.10 can be used to find the design shear stress and the factor of safety. The yield strength of the steel Ibeam is $60,000 \mathrm{psi}(414 \mathrm{kPa})$. This value is less than the yield strength of the bolts.

$$
\begin{aligned}
& \sigma=\mathrm{P} / \mathrm{A} \\
& \mathrm{A}=\mathrm{H}(1 / 4)(2)
\end{aligned}
$$

Solving Equations 3.8, 3.10, 3.11, and 3.12 for the I-beam leads to a factor of safety against failure of the web due to shear equal to 8 .

\section{(iv) Horizontal Deflections of the Reaction Frame}

To prevent the load bar from twisting it needs to be considered like a cantilever beam with some percentage of the force causing it to rotate. As seen in figure 3.3, four 3 inch $x 3$ inch $(7.6 \mathrm{~cm} \times 7.6 \mathrm{~cm})$ steel angles were used for the vertical support. There are two steel angles on each side of the load bar and these angles must resist the cantilever action. If the maximum expected deflection is 5 degrees, the force acting perpendicular to the load bar $(\mathrm{P})$ is given as:

$$
\mathrm{P}=(\sin \theta)(10,000 \mathrm{lb})=872 \mathrm{lb}(3880 \mathrm{~N})
$$

The equation for deflection of a cantilever beam is given as (Kassimali 1995):

$$
\mathrm{y}=(\mathrm{P})\left(\mathrm{L}^{3}\right) / 3 \mathrm{EI}
$$

Given that the total moment of inertia of the four 3 inch $(7.6 \mathrm{~cm})$ steel angles is $10.36 \mathrm{in}^{4}$ $\left(431 \mathrm{~cm}^{4}\right)$ and the length of the cantilever section is 54 inch $(137 \mathrm{~cm})$ (the height of the loading beam as shown in figure 3.3), the maximum horizontal deflection of the load bar would be 0.15 inch $(0.38 \mathrm{~cm})$. All measures would be taken to prevent this bending from occurring, this is only the worst case scenario.

\subsubsection{SUMMARY}

In summary, the following can be said about the design of the pipe testing apparatus. Taking all possible failure modes into consideration, the testing apparatus can sustain a pressure of $70 \mathrm{psi}(480 \mathrm{~Pa})$ or a load of $10,000 \mathrm{lb}(44,500 \mathrm{~N})$ with a minimum factor of safety against failure of 2.62 which occurs in the bolts holding down the lid. However, this is a feature that is easily modified so it can be strengthened if any future tests need to use higher pressures. This factor of safety was found by using conservative 
measures, and was still well above typical acceptable ranges for steel design. Moreover, the bolts will be replaced several times to eliminate any affects of fatigue. The only other factor of safety below 3 is the weld strength of the bottom plate; however, there are a lot of frictional forces in and around the box that were not considered that actually help increase the safety of this potential failure mode. All other components of the box have factors of safety, higher than 3. Table 3.1 shows a summary of all of the deflection values and factors of safety that were calculated.

\subsection{DATA COLLECTION}

To collect the data from inside the pressurized box, a data collection system was developed. A Humboldt data logger that is capable of recording up to 8 signals simultaneously was used. Digital deflectometers that are compatible with the Humboldt data logger were used. The deflectometers have a range of 1 inch $(2.5 \mathrm{~cm})$. The required range was determined to be $10 \%$ of an 8 inch $(20 \mathrm{~cm})$ pipe or 0.8 inch $(2.0 \mathrm{~cm})$. Three soil pressure gauges were used for measuring stresses in the soil mass. A load cell was used to measure the external load.

The instrumentation included three deflectometers placed inside the pipe in a vertical orientation. The deflectometers were placed with one at the center of the pipe and the other two placed at 6 inches from each side as shown in Figure 3.4. One soil pressure cell was placed at the center of the in-situ soil, 2 inches $(5 \mathrm{~cm})$ from the bottom of the test box. The other two cells were placed under the centerline of the pipe. Since the cells are 6 inches $(15 \mathrm{~cm})$ in diameter, their centers are both 3 inches $(7.6 \mathrm{~cm})$ away from the center of the pipe. The placement of these cells is also indicated in Figure 3.4. All of the soil pressure cells were calibrated in the pipe testing apparatus. The soil pressure cells were shown to be accurate within 1 psi $(6.9 \mathrm{~Pa})$ of the surcharge loading for pressure ranges between 5 psi and 50 psi (35 Pa to $345 \mathrm{~Pa})$. The soil pressure cells are less accurate for pressures below 5 psi (35 Pa).

A small slit was cut in the lid so that the instrumentation wires could pass to the outside of the test box. There was also a circular hole cut in the lid over the center of the test box. This hole allowed direct loading to be applied through a load plate at the same time as the surcharge loading was being applied. This simultaneous load configuration 
Table 3.1: Summary of Design Results

\begin{tabular}{|l|l|l|}
\hline Factors of Safety and Deflections When & \multicolumn{2}{l|}{ Operating Pressure } \\
\cline { 2 - 3 } Pressurizing & $\mathbf{3 2}$ psi & $\mathbf{7 0}$ psi \\
\hline Deflection of box on 40" side & $0.004 "$ & $0.0091 "$ \\
\hline Deflection of box on 25" side & $0.004 "$ & $0.009{ }^{\prime \prime}$ \\
\hline Factor of safety (lid bolts) & 5.72 & 2.62 \\
\hline Factor of safety (welds on 25" side) & 11.22 & 5.13 \\
\hline Factor of safety (welds on 40" side) & 7.94 & 3.63 \\
\hline Factor of safety (welds on bottom) & 6.45 & 2.95 \\
\hline Factor of safety (failure of top rim) & 6.96 & 3.18 \\
\hline Factors of Safety and Deflections For the Reaction Frame at 10,000 lb \\
\hline Vertical deflection of the load bar & $0.012 ”$ \\
\hline Horizontal deflection of the load bar & $0.15 ”$ \\
\hline Factor of safety (bolts) & 3.67 \\
\hline Factor of safety (web) & 8 \\
\hline
\end{tabular}


A. Test box from side

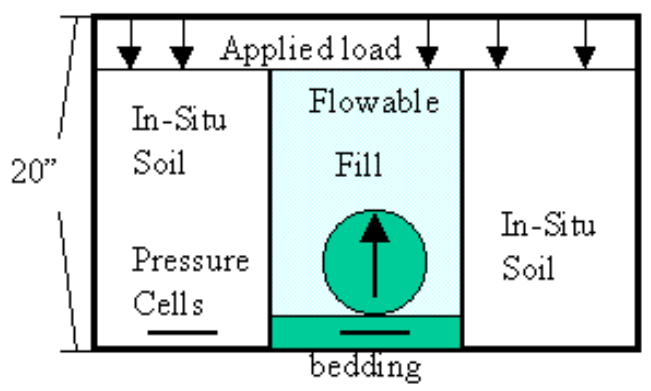

B. Test box from top

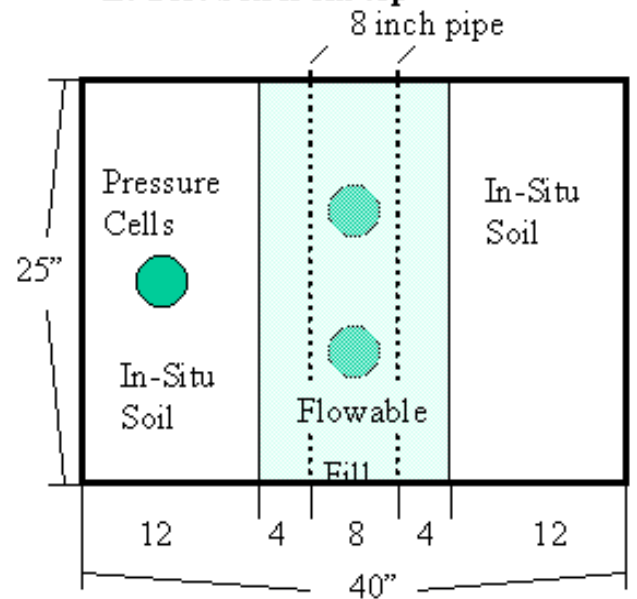

C. Configuration of deflectometers

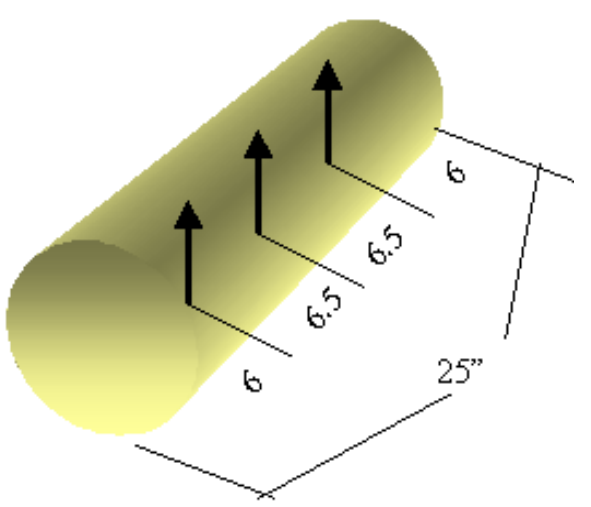

Figure 3.4: Configuration of Instrumentation 
was not used in this research project. The direct loading experiments were always conducted without any applied surcharge loading.

\subsection{PIPE TESTING APPARATUS}

A final pipe testing apparatus that met all the requirements for this research project was designed and built. The pipe testing apparatus can be safely pressurized to 70 psi $(483 \mathrm{~Pa})$ or a 5 ton $(44.5 \mathrm{kN})$ direct load can be applied directly to the backfill. The entire structure was designed to minimize weight without compromising any strength. The structure is light enough that it can be transported on a dolly. It is rigid enough that no discernable deflections have been noticed while conducting experiments. Figure 3.5 shows a picture of the pipe testing apparatus. 


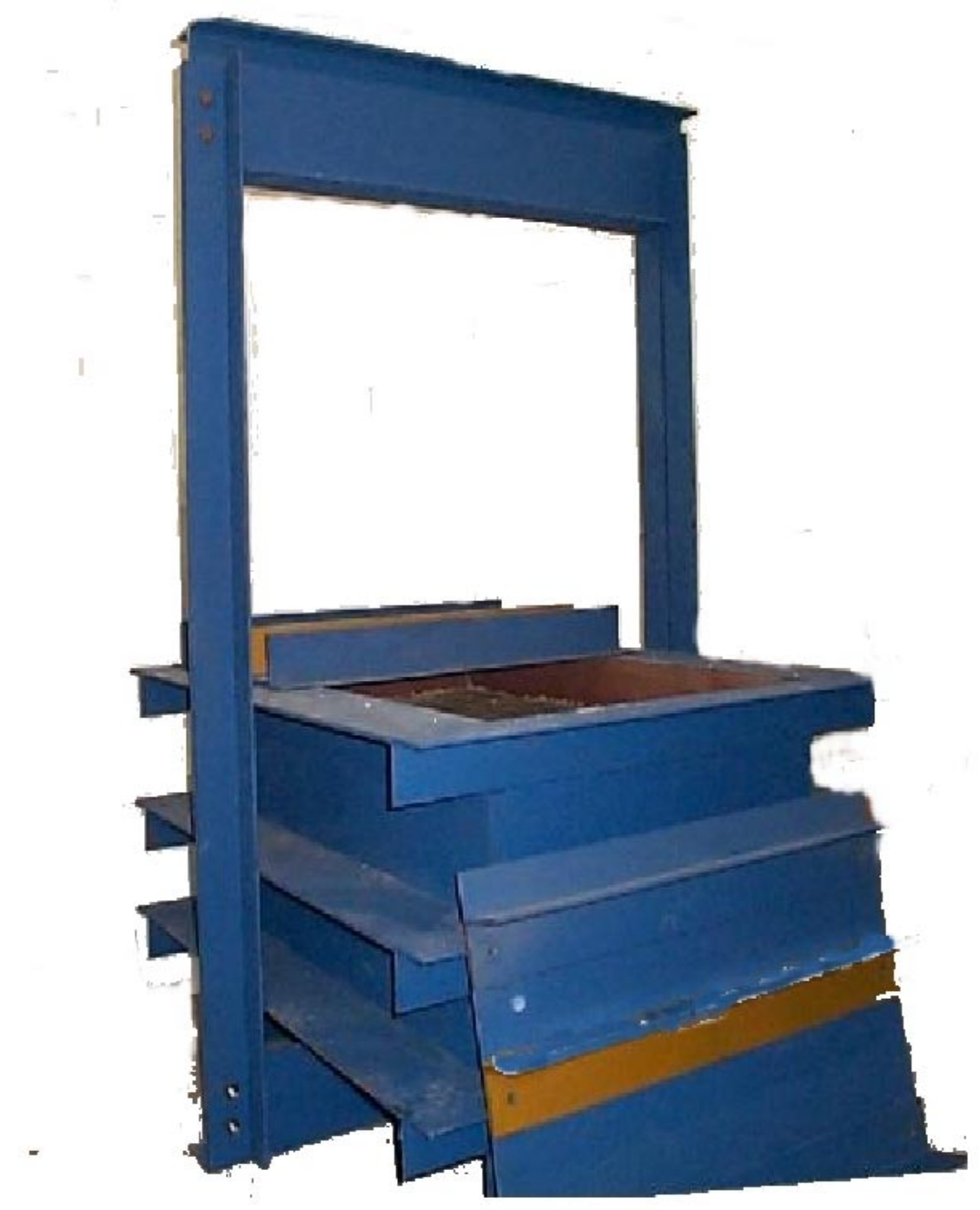

Figure 3.5: Completed Pipe Testing Apparatus 


\section{CHAPTER 4}

\section{EXPERIMENTAL PROCEDURES}

In this chapter, the experimental procedures are discussed. First, background information on the two types of in-situ soil used in this research is presented. The procedures for placing the in-situ soil in the pipe testing apparatus are also discussed. The operational procedures for conducting the pipe testing are outlined, as well as the pipe preparation procedures. Specific information about the properties of the pipes is found in sections 5.1 and 6.1 .

\subsection{IN-SITU SOIL PREPERATION}

Two soils were used as in-situ material. This is the soil that is used to fill the portion of the box not being filled with the flowable fill. The width of this in-situ material would vary anywhere from $15.5(39 \mathrm{~cm})$ on each side for a 9 inch $(22 \mathrm{~cm})$ trench width to 8 inch $(20 \mathrm{~cm})$ on each side for a 24 inch $(61 \mathrm{~cm})$ trench width. The two soils used were a compacted cohesive soil and a loose non-cohesive soil. Both soils were held in place with soil dividers until after the CLSM was poured in place. The soil dividers can be seen in Figure 4.1. The inner surface of the entire test box was oiled and lined with a plastic sheet before placing any soil in it. This greatly reduces the friction between the soils and the test box. The plastic sheet was replaced when it was damaged or torn so that the testing set up would be consistent for all pipe tests.

The loose non-cohesive soil was the same river sand used for the CLSM mixtures described in section 2.3. The sand was not sieved and no effort was made to compact it. Once the soil dividers were in place, the soil was simply poured on both sides until the sides were filled. A soil pressure cell was always placed on the left side 2 inches $(5 \mathrm{~cm})$ from the bottom of the box. The geometry is symmetric so there is no difference between placing the soil pressure cell on the left or the right sides.

The same sand was also used for the bedding material. The bedding was prepared by pouring 2 inches $(5 \mathrm{~cm})$ of sand into the trench, placing both of the soil pressure cells, and filling in another 2 inches $(5 \mathrm{~cm})$ of loose sand. The sand was then tamped down to a 3 inch $(7.5 \mathrm{~cm})$ thickness. 


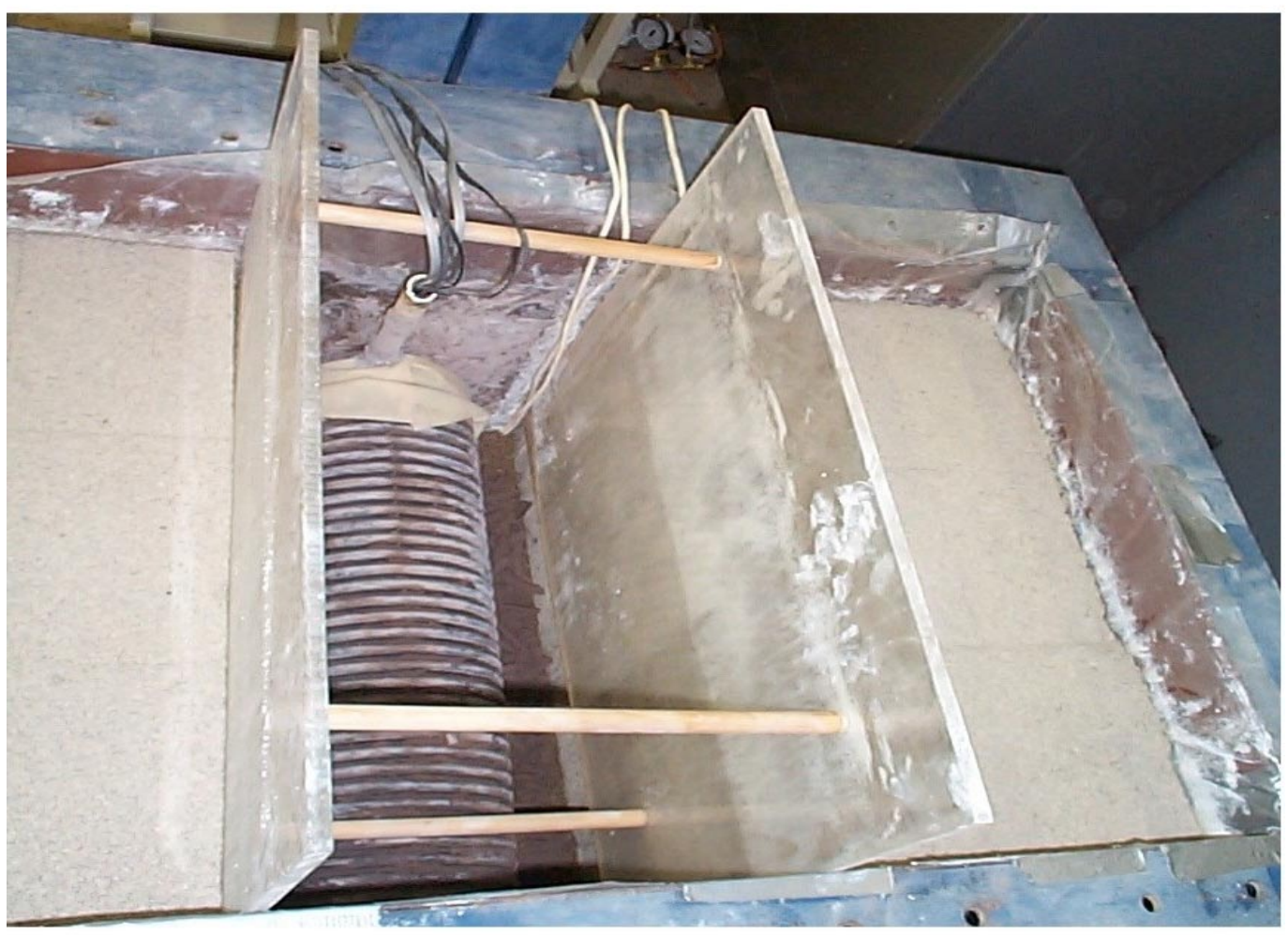

Figure 4.1: Prepared Trench for the Pipe 
The cohesive soil was a mixture of $10 \%$ Kaolin and $90 \%$ river sand on a dry weight basis. The mixture was always kept at moisture contents between $9 \%$ and $12 \%$. This mixture was placed in three 6 inch $(15 \mathrm{~cm})$ lifts. The soil would be scooped into each side to a depth of about 8 inches $(20 \mathrm{~cm})$. The soil was then smoothed out with a spoon to give a level surface at a depth of 7 inches $(18 \mathrm{~cm})$. The soil was then compacted by using an 8 inch x 8 inch $(20 \mathrm{~cm}$ x $20 \mathrm{~cm})$ plate. The plate was moved around to cover the entire surface and at each location the plate was struck three times with a standard compaction hammer. Both sides of the trench were prepared before compaction to make sure that the trench dividers did not shift from the compaction effort. The instrumented pipe was placed in the trench before compaction began. By having the pipe in place before filling the sides, the trench dividers could be left in place. If the pipe was not already in the trench, one would not be able to place the pipe into the trench because the trench shoring would be in the way. Figure 4.1 shows the pipe placed in the trench and the compacted soil around the trench with the soil dividers still in place. The configuration shown in Figure 4.1 is the final stage before the trench was filled except for shoring the pipe against flotation.

Figure 4.1 also shows some of the preparation at the ends of the pipe. The pipes used were corrugated polyethylene (PE). The pipes had no liner, so there were corrugations on the inside of the pipe as well. The pipe sections were cut to the proper length with a utility knife. The open ends of the pipe were sealed with plastic membranes to keep the flowable fill from filling the pipe. The instrumentation wires also had to come out of the pipe. The instrumentation wires were enclosed in a short piece of PVC tubing to protect them from potential damage. The 25 inch $(64 \mathrm{~cm})$ section of pipe was instrumented and sealed before mixing the flowable fill so that the pipe instrumentation could be tested before it was too late to correct any errors. The only other preparation was to shore the pipe against flotation. Propping two wooden dowel rods between the pipe and the load beam sufficiently prevented flotation during the placement of flowable fill.

Once the box reached the stage in Figure 4.1, the flowable fill was prepared. The dry ingredients and the water were gradually added to a mortar mixer until all of the material was being mixed. A flowability test was performed when the mixture was fully mixed to make sure that the flowable fill would have 9 inch $(23 \mathrm{~cm})$ spread. The mixture 
was poured into the trench with a large bowl, one bowl at a time. When the trench was full, the soil dividers were removed and then cleaned. After 10 to 20 minutes the material usually had set enough for the flotation shoring to be removed. The entire box was then covered with a plastic sheet and left alone for 48 hours.

\subsection{PREPARATION OF THE TEST BOX}

After 48 hours of letting the flowable fill cure, the box was prepared for surcharge loading. The surcharge loading was applied with eight motorcycle inner tubes as described in chapter 3 . The inner tubes were each 6 inches $(15 \mathrm{~cm})$ wide with a 16 inch $(41 \mathrm{~cm})$ diameter. This size inner tube has a circumference of 50 inches $(128 \mathrm{~cm})$. If the tube is folded flat in half it will cover a rectangular area of 25 inch by 6 inch $(64 \mathrm{~cm}$ by $15 \mathrm{~cm}$ ) and the tube stem will be sticking straight up. Placing eight of these tubes side by side covered the entire 40 inch by 25 inch $(102 \mathrm{~cm}$ by $64 \mathrm{~cm})$ loading area with no voids. These tubes were confined to a height of only 2 inches $(5 \mathrm{~cm})$ so they do not move or shift when being pressurized. Several preliminary tests were done with the inner tubes to insure that the pressure distribution would be even. For this preliminary testing the test box was entirely filled with the cohesive soil and then sealed for pressurizing. After pressurizing the box, the soil surface could be examined to see the patterns that the inner tubes left on the soil surface. These tests showed that the soil surface deformed evenly across the whole loading area and there were no ridges or voids formed from the seams between two adjacent inner tubes.

When the inner tubes were in place, the lid was fastened. All eight of the inner tube stems were protruding from the lid. The tubes were then hooked up to pressure regulators. The three inner tubes on the left and the three inner tubes on the right were put together as two different groups and were hooked up to two pressure regulators. The two inner tubes in the center were hooked up to the third pressure regulator. This set up allows variable pressure to be applied across the loading surface, including a more intense load directly over the centerline of the pipe. However, a variable pressure configuration was not used in this research. The pressure gauges used were accurate to $1 / 2$ psi (3.4 Pa) for pressure ranges of 0 to $100 \mathrm{psi}(690 \mathrm{~Pa})$. There were also three additional pressure gauges at the inner tube stems that were accurate to $1 \mathrm{psi}(7 \mathrm{~Pa})$ for pressure 
ranges of $10 \mathrm{psi}(70 \mathrm{~Pa})$ to $60 \mathrm{psi}(410 \mathrm{~Pa})$. These less accurate gauges were used only for verification purposes. They would be able to warn if any of the inner tube sets was not receiving the correct pressure.

\subsection{OPERATIONAL PROCEDURES}

Once the test box was prepared for testing, an initial set of readings was taken. These readings include the three initial deflectometer readings and the three initial soil stress readings. The test box was then pressurized to $5 \mathrm{psi}(34 \mathrm{~Pa})$ and another set of readings was taken when the readings became constant. The time required for the readings to become constant varied with different tests. For the high strength flowable fill tests there was almost no movement at 5 psi (34 Pa) so the system stabilized quickly. For the low strength flowable fill with narrow trench widths the waiting time for stabilization was several minutes. After these readings were taken, the pressure was increased 1 psi ( 7 $\mathrm{Pa})$ at a time up to $10 \mathrm{psi}(69 \mathrm{~Pa})$ and another set of readings was taken when the readings stabilized. The readings were taken at 5 psi $(34 \mathrm{~Pa})$ increments up to $30 \mathrm{psi}(207 \mathrm{~Pa})$. Many of the experiments took as much as 30 minutes to stabilize under an applied surcharge load of $30 \mathrm{psi}$ (207 Pa). However, during this 30-minute stabilizing period, the total measured deflection only increased by about 1 to 2 one-hundredths of an inch $(0.25$ to $0.5 \mathrm{~mm})$. Since the total deflections at $30 \mathrm{psi}(207 \mathrm{~Pa})$ were often in the range of $1 / 2$ inch $(1.3 \mathrm{~cm})$, this means that more than $95 \%$ of the total deflection would occur as soon as the pressure was applied. The pressure was then gradually released and a reading was taken at 0 psi $(0 \mathrm{~Pa})$ after the readings had stabilized. This reading was commonly taken after $1 / 2$ hour. The last set of readings was taken after 24 hours. This 24 -hour reading serves two purposes. It marks the starting point for the direct loading and it gives an indication of how much the system will rebound after removal of surcharge loading.

The direct loading was more of a laboratory measure than a practical field simulation. It was assumed to simulate the influence of a wheel load. A steel plate with dimensions of 12 inch $\times 12$ inch x $1 / 2$ inch thick $(31 \mathrm{~cm} \times 31 \mathrm{~cm} \times 1.3 \mathrm{~cm}$ thick) was placed directly above the centerline of the pipe. The pipe only had about 7 inches $(18 \mathrm{~cm})$

of cover in the laboratory. In the field the pipe would have at least two feet $(61 \mathrm{~cm})$ of cover. Therefore, this loading does not reflect any practical field loading scenarios for the 
WVDOT. However, many people place flexible pipes at the head of their driveways that are not more than 6 inches $(15 \mathrm{~cm})$ deep. Wheel loads on this type of pipe would be similar to the loading configuration in this test. This test also helps get a better understanding of the pipe-soil interactions so its inclusion is beneficial.

The apparatus was designed to use direct loading in conjunction with the surcharge loading. However, in this research work direct loading was used without any applied surcharge load. The load plate was placed and then an eight-ton jack was used to apply the load on the plate. The eight-ton jack was hand operated. A load cell was placed directly above the jack and a small load plate with a rotator cusp was placed on the top end of the jack to distribute the load to the load cell. The load cell has a maximum capacity of $10,000 \mathrm{lb}(44.5 \mathrm{kN})$ and measures the load with a minimum accuracy of $10 \mathrm{lb}$ $(44 \mathrm{~N})$. The test was performed by slowly jacking the jack until the load cell read a load of $1,000 \mathrm{lb}(4,450 \mathrm{~N})$. This load was maintained for at least 20 seconds and then slowly increased up to $2,000 \mathrm{lb}(8,900 \mathrm{~N})$. This process was continued in $1,000 \mathrm{lb}(4,450 \mathrm{~N})$ increments until it was no longer possible to maintain a constant load. Since the flowable fill was deflecting under the jack, the load was constantly decreasing as the settlements took place. For smaller loads it was easy to add more pressure to the jack to keep the load range within $\pm 20 \mathrm{lb}(90 \mathrm{~N})$. For loads higher than 5,000 lb (22.2 kPa), it becomes difficult to maintain the load near the target load. Most of the fills took between 5,000 $\mathrm{lb}$ and $7,000 \mathrm{lb}(22 \mathrm{kPa}$ and $31 \mathrm{kPa})$ loads. The data collection was automated so the load, the soil stresses, and the pipe deflections were all logged simultaneously while the experiment was conducted. After the maximum load was reached, the pressure in the jack was released and the system was allowed to rebound. When the readings stabilized the data collection system was terminated. This portion of the experiment usually took about 20 minutes for completion.

The flowable fill was then removed and discarded. The in-situ soil was removed and kept for the next experiment. The in-situ soil was always kept covered between experiments to keep it from drying out. It was stated earlier that the cohesive in-situ soil was kept at a water content of $9 \%$ to $12 \%$. Water content measurements were regularly taken, and water was periodically added to insure that all the tests were conducted with a soil that had a similar water content. 


\section{CHAPTER 5}

\section{EXPERIMENTAL RESULTS}

One of the primary objectives of this research was to find the influence of the trench width ratio on the overall performance of buried pipe. Independent and dependent variables used in this research are identified in this chapter. These variables will each be examined and the relationship of these variables to the trench width ratio will be considered. Experimental data from the laboratory buried pipe testing are presented, as well as a discussion on the significance of this data and the trends that the data illustrate.

\subsection{EXPERIMENTAL VARIABLES}

The control variables in this experiment were, pipe diameter (d), trench width ratio $\left(\mathrm{n}_{\mathrm{r}}\right)$, in-situ soil strength, CLSM strength, and loading. The dependent variables were the pipe deflections and the soil stresses. Since all tests were done with the same type of pipe, pipe stiffness was a constant for any given pipe diameter. The stiffness values of 6 inch $(15.2 \mathrm{~cm})$ and 8 inch $(20.3 \mathrm{~cm})$ pipes were $49 \mathrm{psi}(337.9 \mathrm{~Pa})$ and $35 \mathrm{psi}$ $(241.3 \mathrm{~Pa})$, respectively. Both of these values were measured in the laboratory using ASTM Test Method for Pipe Stiffness (D 2412). This ASTM method also shows how to find the modulus of elasticity (E) from the information obtained in the pipe stiffness test. The calculated values for the modulus of elasticity at 5\% deflections for the 6 inch (15.2 $\mathrm{cm})$ and 8 inch $(20.3 \mathrm{~cm})$ pipes were $94 \mathrm{ksi}(648.1 \mathrm{kPa})$ and $67.2 \mathrm{ksi}(463.3 \mathrm{kPa})$, respectively. These calculated pipe stiffness values were very close to the values reported by the pipe manufacturers. When doing calculations in this research, the only pipe stiffness and pipe modulus of elasticity values used are the values measured in the laboratory, not the values supplied by the manufacturers.

The trench width was varied by at least three values for every test configuration. The experimental program included trench width ratios of 1.5, 2.0, and 2.5 except for two tests for which a trench width ratio of 3.0 was used. Having at least three points on a graph gives a better feel for the relationship between the variables of interest. The graphs relating trench width ratio and pipe deflections are some of the most relevant results of this report. All of the graphs and data are presented in more detail in the following 
sections. These figures show a tendency for larger trench widths to reduce the deflections in the pipe.

The in-situ soil was varied by two types, a low strength soil and a high strength soil. Since only two types of in-situ soil were used, it would not be possible to make predictions to other soil strengths with any level of confidence. The CLSM results also only compare two different strengths. The two CLSM mixes tested in this study were a WVDOT class A mixture with a compressive strength of $280 \mathrm{psi}(1,931 \mathrm{~Pa})$ and a WVDOT class $\mathrm{C}$ mixture with a compressive strength of $1,150 \mathrm{psi}(7,929 \mathrm{~Pa})$. The strength of WVDOT class A mixtures only range from $50 \mathrm{psi}(345 \mathrm{~Pa})$ to $300 \mathrm{psi}(2,069$ $\mathrm{Pa}$ ) and the strength of WVDOT class $\mathrm{C}$ mixtures should only range from 1,000 psi $(6,895 \mathrm{~Pa})$ to $1,200 \mathrm{psi}(8,274 \mathrm{~Pa})$. There is not a wide range of permitted CLSM strength values that can be tested when using these two mixtures. While the two strength values that were tested provide information beneficial to comparing a low strength CLSM to a high strength CLSM, a few intermediate WVDOT class B mixtures should be tested in order to determine a relationship between CLSM strength and the other variables.

The pipe diameters also only varied by two values. A comparison of 6 inch (15.2 $\mathrm{cm})$ and 8 inch $(20.3 \mathrm{~cm})$ pipe measurements is valuable for relating the information to other pipe diameters. However, before any conclusive statements could be made about the relationships between pipe diameter and the other variables, more pipe diameters should be tested. It appears that WVDOT does not use any pipe smaller than 18 inch (46 $\mathrm{cm}$ ) in new construction and there is no official upper limit on permissible pipe sizes (WVDOT 2000). Time constraints limited the scope of this research from covering more than two pipe diameters, but future research should incorporate more pipe diameters so that this valuable data can be collected.

\subsection{PIPE DEFLECTIONS DUE TO SURCHARGE LOADING}

All of the data from the pipe testing can be found in appendix C. The following figures (Figures 5.1 through 5.4) show families of curves for surcharge loading from 10 psi $(69 \mathrm{~Pa})$ to $30 \mathrm{psi}(207 \mathrm{~Pa})$. In these figures, deflections are compared to the trench 
Deflections Under Uniform Surcharge Loading recorded in inches

\begin{tabular}{|c|c|c|c|c|c|c|}
\hline & $\begin{array}{l}\text { 10psi (69 } \\
\text { Pa) }\end{array}$ & & \begin{tabular}{|l|}
$20 p s i$ \\
$(138 \mathrm{~Pa})$
\end{tabular} & & $\begin{array}{l}30 \mathrm{psi} \\
(207 \mathrm{~Pa})\end{array}$ & \\
\hline $\begin{array}{l}\text { trench } \\
\text { width } \\
\text { ratio } n_{r}\end{array}$ & $\begin{array}{c}6 \text { inch } \\
\text { pipe }\end{array}$ & $\begin{array}{l}8 \text { inch } \\
\text { pipe }\end{array}$ & $\begin{array}{c}6 \text { inch } \\
\text { pipe }\end{array}$ & $\begin{array}{l}8 \text { inch } \\
\text { pipe }\end{array}$ & $\begin{array}{c}6 \text { inch } \\
\text { pipe }\end{array}$ & $\begin{array}{l}8 \text { inch } \\
\text { pipe }\end{array}$ \\
\hline 1.5 & 0.1017 & 0.4229 & 0.2259 & 0.727 & 0.3244 & \\
\hline 2 & 0.07 & 0.0747 & 0.1523 & 0.151 & 0.2362 & 0.2168 \\
\hline 2.5 & 0.0473 & 0.056 & 0.0967 & 0.131 & 0.141 & 0.2275 \\
\hline 3 & 0.064 & & 0.167 & & 0.2801 & \\
\hline
\end{tabular}

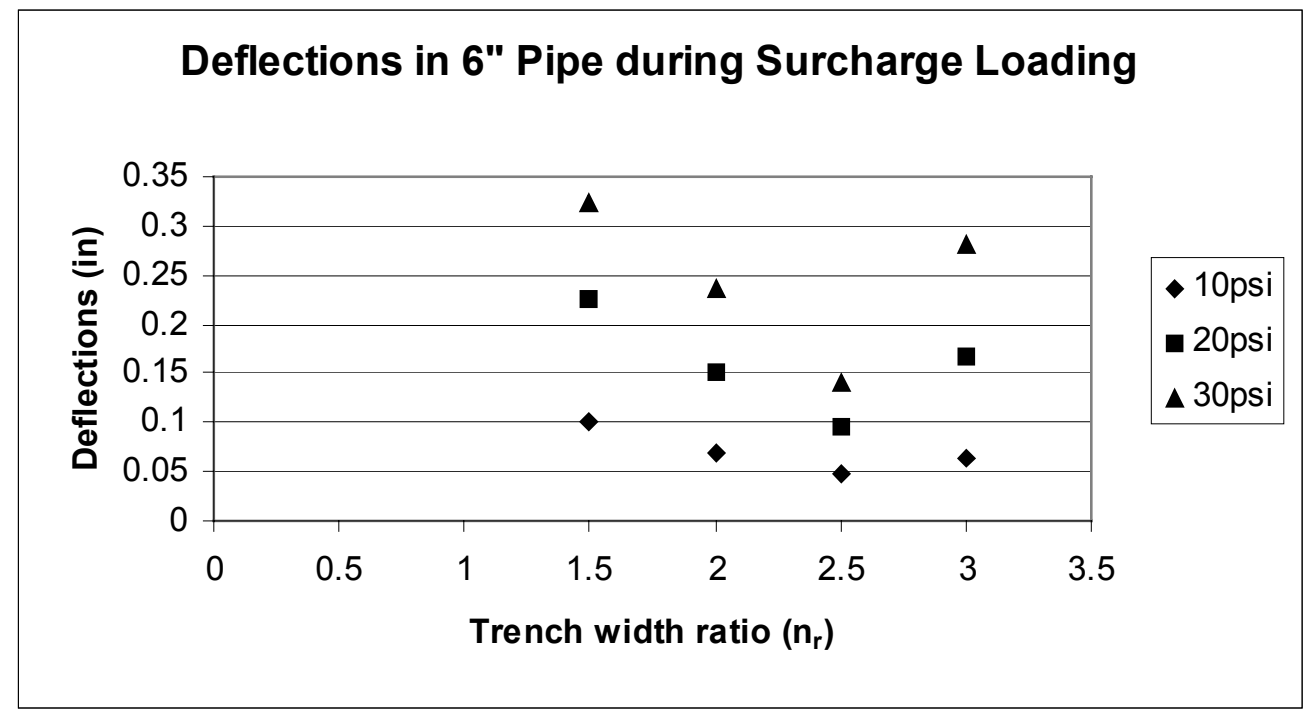

\section{Deflections in 8" Pipe during Surcharge Loading}

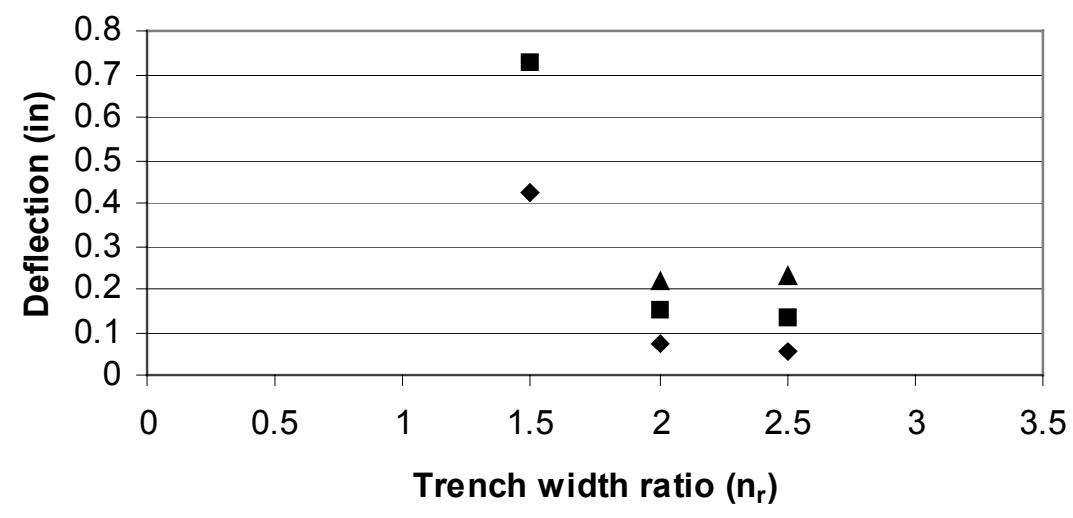

-10psi

- 20psi

\30psi

Figure 5.1: Deflections of Pipes in Cohesive In-Situ Soil With Low Srength Backfill 
Deflections Under Uniform Surcharge Loading recorded in inches

\begin{tabular}{|c|c|c|c|c|c|c|}
\hline & $\begin{array}{l}\text { 10psi (69 } \\
\mathrm{Pa})\end{array}$ & & \begin{tabular}{|l}
$20 p s i$ \\
$(138 \mathrm{~Pa})$
\end{tabular} & & \begin{tabular}{|l}
$30 p s i$ \\
$(207 \mathrm{~Pa})$
\end{tabular} & \\
\hline $\begin{array}{l}\text { trench } \\
\text { width } \\
\text { ratio } n_{r}\end{array}$ & $\begin{array}{c}6 \text { inch } \\
\text { pipe }\end{array}$ & $\begin{array}{c}8 \text { inch } \\
\text { pipe }\end{array}$ & $\begin{array}{c}6 \text { inch } \\
\text { pipe }\end{array}$ & $\begin{array}{l}8 \text { inch } \\
\text { pipe }\end{array}$ & $\begin{array}{l}6 \text { inch } \\
\text { pipe }\end{array}$ & $\begin{array}{l}8 \text { inch } \\
\text { pipe }\end{array}$ \\
\hline 1.5 & 0.0016 & 0.1808 & 0.028 & 0.3696 & & 0.482 \\
\hline 2 & 0.0245 & 0.0323 & 0.069 & 0.0973 & & 0.162 \\
\hline 2.5 & 0.0071 & 0.0099 & 0.037 & 0.0454 & & 0.0856 \\
\hline 3 & & & & & & \\
\hline
\end{tabular}

\section{Deflections in 6" Pipe during Surcharge Loading}
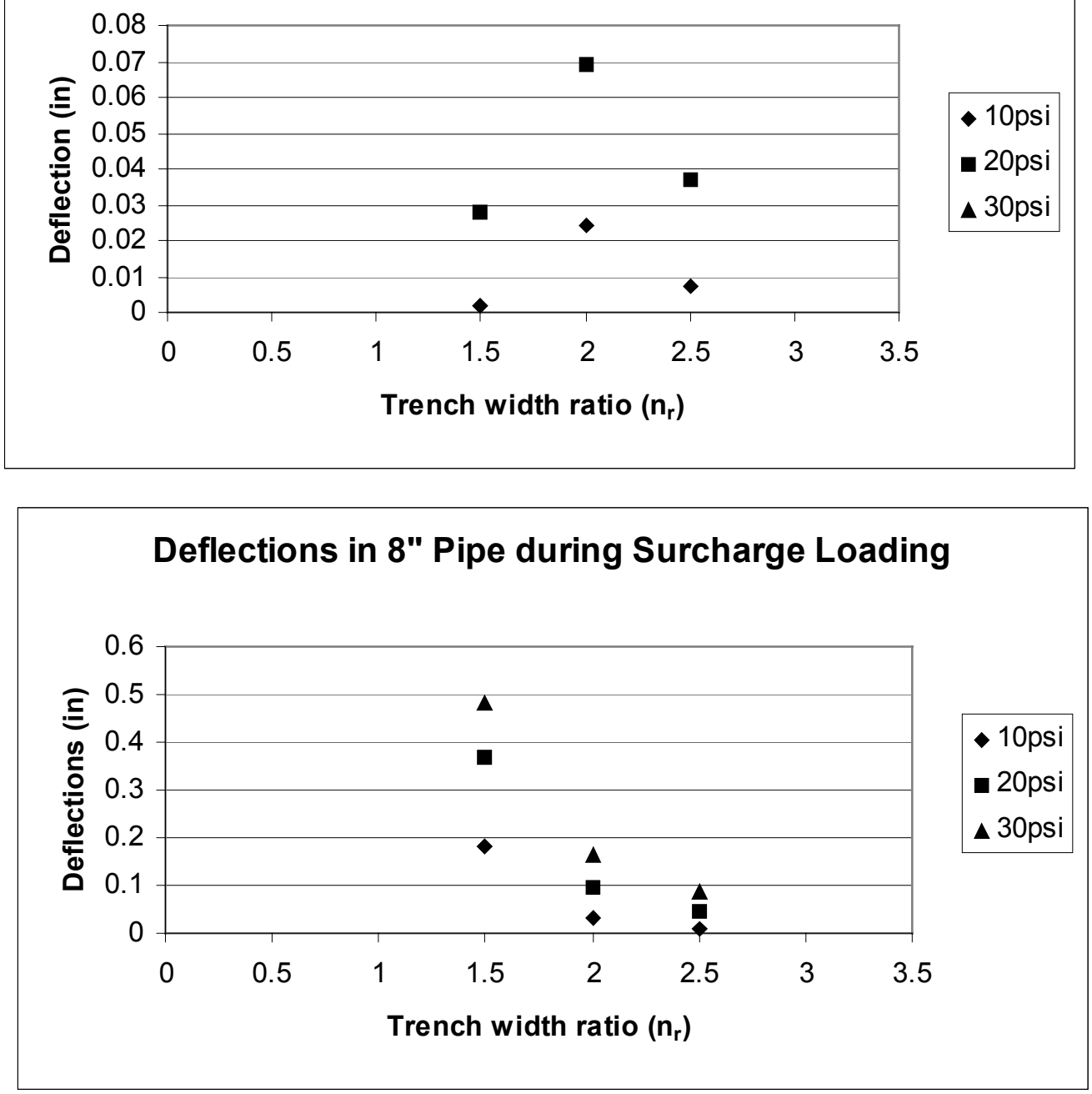

Figure 5.2: Deflections of Pipe in Cohesive In-Situ Soil With High Strength Backfill 
Deflections Under Uniform Surcharge Loading recorded in inches
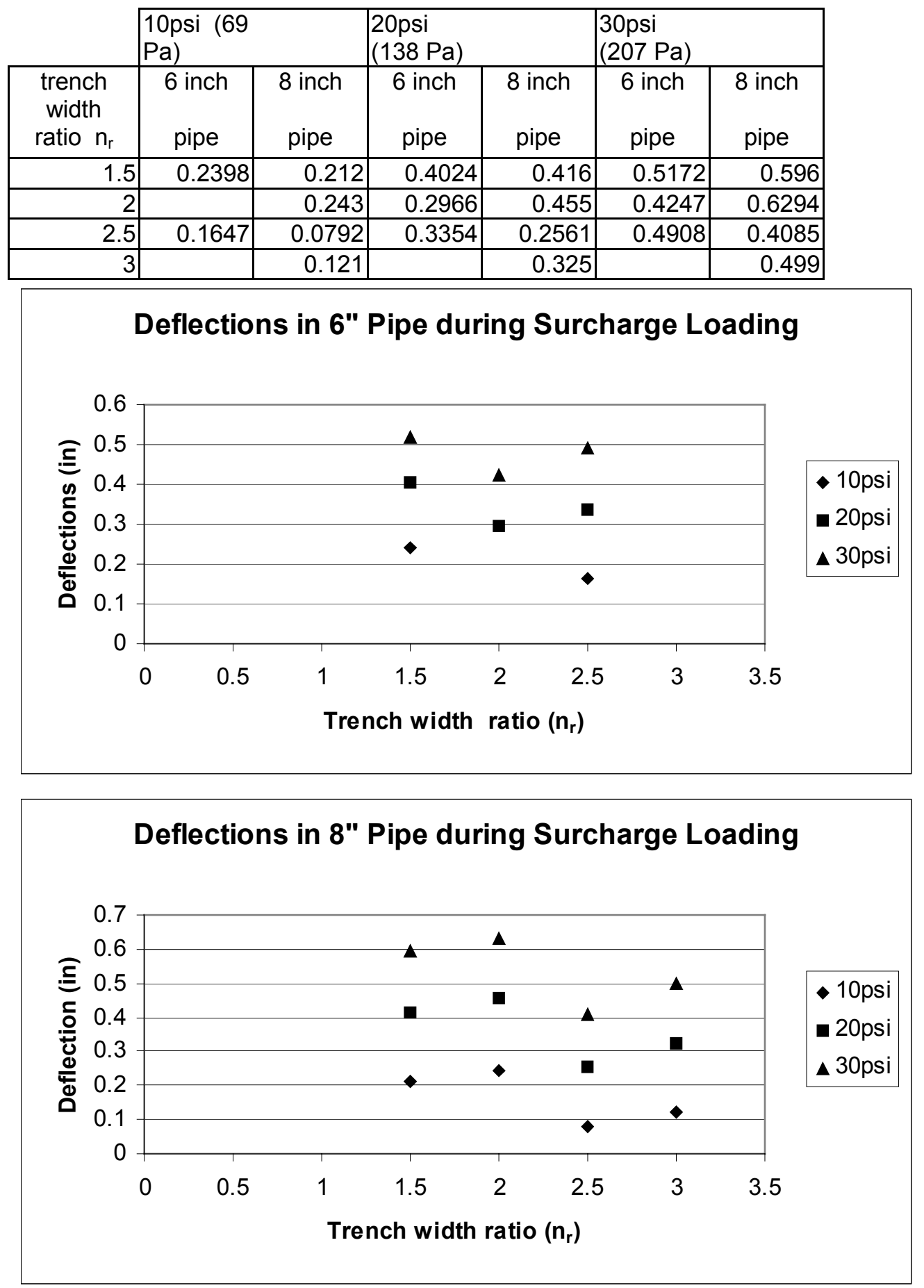

Figure 5.3: Deflections of Pipe in Loose In-Situ Soil With Low Strength Backfill 
Deflections Under Uniform Surcharge Loading recorded in inches

\begin{tabular}{|c|c|c|c|c|c|c|}
\hline & $\begin{array}{l}\text { 10psi (69 } \\
\mathrm{Pa})\end{array}$ & & $\begin{array}{l}20 p s i \\
(138 \mathrm{~Pa})\end{array}$ & & $\begin{array}{l}30 \mathrm{psi} \\
(207 \mathrm{~Pa})\end{array}$ & \\
\hline $\begin{array}{l}\text { trench } \\
\text { width } \\
\text { ratio } n_{r}\end{array}$ & $\begin{array}{c}6 \text { inch } \\
\text { pipe }\end{array}$ & $\begin{array}{l}8 \text { inch } \\
\text { pipe }\end{array}$ & $\begin{array}{c}6 \text { inch } \\
\text { pipe }\end{array}$ & $\begin{array}{l}8 \text { inch } \\
\text { pipe }\end{array}$ & $\begin{array}{c}6 \text { inch } \\
\text { pipe }\end{array}$ & $\begin{array}{l}8 \text { inch } \\
\text { pipe }\end{array}$ \\
\hline 1.5 & 0.0245 & 0.029 & 0.0649 & 0.127 & 0.102 & 0.1327 \\
\hline 2 & 0.0194 & 0.0359 & 0.0377 & 0.0922 & 0.0566 & 0.1425 \\
\hline 2.5 & 0.031 & 0.0269 & 0.0527 & 0.0671 & 0.0699 & 0.106 \\
\hline 3 & & & & & & \\
\hline
\end{tabular}
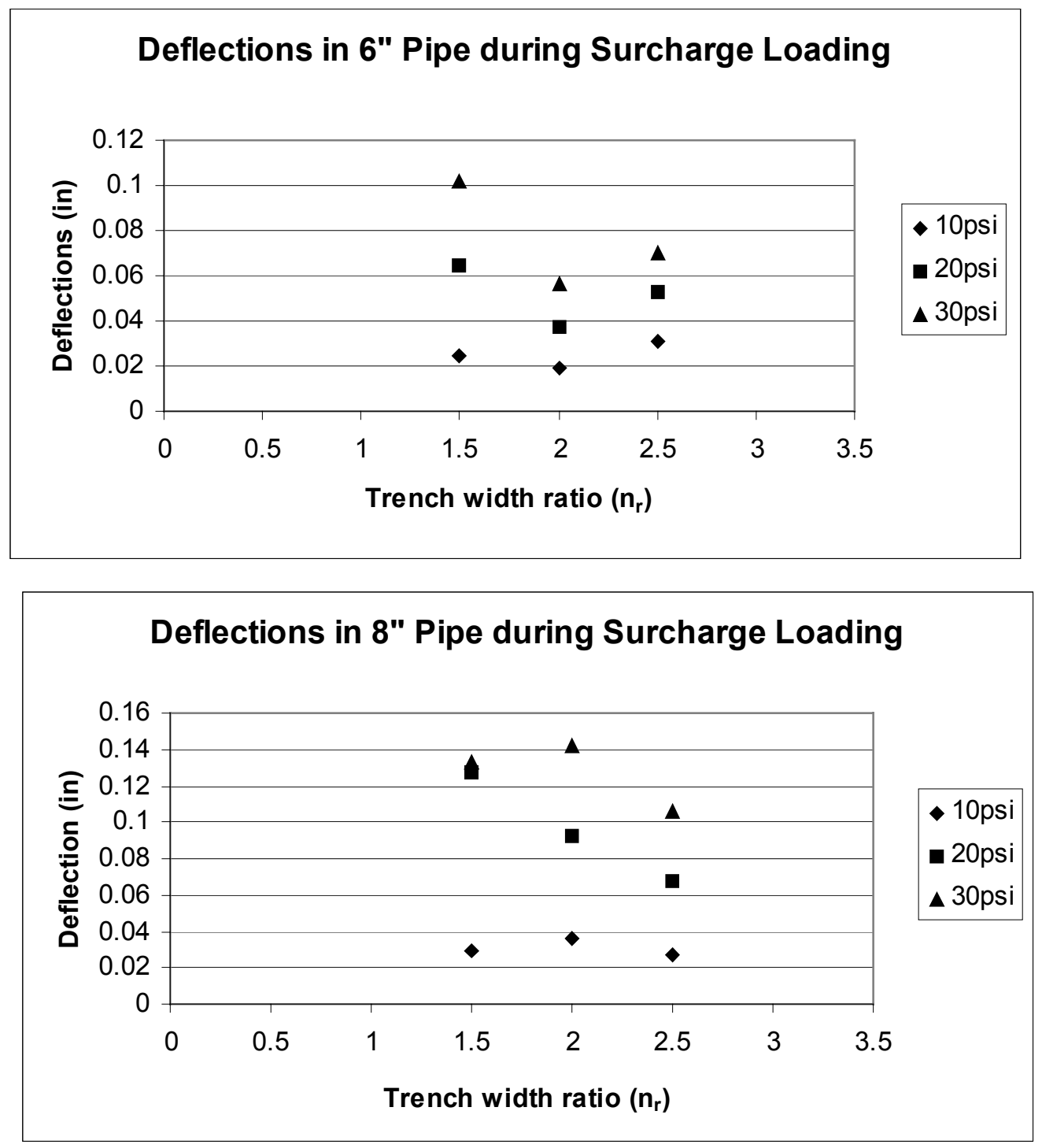

Figure 5.4: Deflections of Pipe in Loose In-Situ Soil with High Strength Backfill 
width ratio $\left(\mathrm{n}_{\mathrm{r}}\right)$. The trench width ratio is defined as the trench width divided by the pipe diameter.

From the preceding graphs and tables several conclusions can be drawn about the relationships between the variables. Figures 5.1 through 5.4 show a definite trend for the pipe deflections to decrease with an increase in trench width. This is as expected, because a larger trench width provides more structural integrity than does a smaller trench width. When using the Spangler's Iowa equation (Howard 1996) to predict deflections, a wider trench width will result in less deflection. This equation and its use are presented in more detail in the following chapter. One interesting feature of these graphs is that the slopes of the trend lines are very similar for all of the different configurations. The average slope of all of the trend lines at $20 \mathrm{psi}(138 \mathrm{~Pa}$ ) in Figures 5.1 through 5.4 is 0.062 . The range of values for the slope is from 0.04 to 0.095 . With more testing of different pipe diameters a reliable correlation between the trench width and the pipe deflections can be obtained.

These figures also show the performance of the pipes with respect to the $5 \%$ deflection limit. Every test conducted with low strength CLSM at trench width ratios of 1.5 had deflections greater than the $5 \%$ limit at $30 \mathrm{psi}(207 \mathrm{~Pa})$ surcharge loading. However, $30 \mathrm{psi}(207 \mathrm{~Pa})$ is more surcharge than most pipes will ever carry in service so this information does not exclude trench width ratios of 1.5 from service. At surcharge pressures of $20 \mathrm{psi}(138 \mathrm{~Pa})$ only 3 out of 8 mixtures showed $5 \%$ deflection at a trench width ratio of 1.5 and only 1 out of 8 mixtures showed $5 \%$ deflections at a trench width ratio of 2.0. Both tests that combined the low strength CLSM with the low strength insitu soil had deflections greater than the $5 \%$ limit at every trench width ratio when the surcharge pressure was increased to $30 \mathrm{psi}(207 \mathrm{~Pa})$.

Most pipes will not even carry 20 psi (138 Pa) of surcharge in service (Watkins and Anderson 2000). At a surcharge loading of $20 \mathrm{psi}$ (138 Pa) there was only one experimental set up (Figure 5.1, 8 inch pipe, $\mathrm{n}_{\mathrm{r}}$ of 1.5) where a pipe had a deflection that was greater than $7 \%$. There is a current effort to increase the allowable flexible pipe deflections to $7 \%$ for design purposes (Gabriel 1998). If the limit was at $7 \%$ then the performance of all of the mixtures at any trench width can be considered as very good. 


\subsection{SOIL STRESSES DUE TO SURCHARGE LOADING}

Appendix $\mathrm{C}$ also contains the data for soil stresses due to surcharge loading. The following figures (Figures 5.5 through 5.8) also show families of curves for surcharge loading between $10 \mathrm{psi}(69 \mathrm{~Pa})$ and $30 \mathrm{psi}(207 \mathrm{~Pa})$ but these figures show the soil stresses under the centerline of the pipe compared with the trench width ratio. The centerline soil stress decreases with an increase in trench width ratio. The theory of arching indicates that when a material in a trench deflects the frictional forces on the interface between the in-situ soil and the backfilled material will carry some of the surface load (Watkins and Anderson 2000). This reduction in stress can actually cause negative pressures near the crown of the pipe and lead to tension cracks. However, in the case of flowable fill the backfilled material is much stronger and deflects less than the insitu soil. This leads to a phenomenon that is opposite that of arching. In this case, the insitu soil is deflecting and the CLSM is taking on additional loads due to the friction caused by the moving mass of in-situ soil. The loads in the CLSM are being amplified rather than reduced.

In a finite area, such as the area of the pipe testing apparatus used in this research, as the trench width is increased the area of in-situ soil that is under pressurized surface loading must decrease. Since the pressurized area of the in-situ soil is decreasing so is the frictional forces that the in-situ soil is applying to the CLSM. Arching theory is applied when there are two soil masses that settle at different rates. In the case of CLSM, the load distributions are opposite of what is expected from conventional arching theory. The insitu soil is applying additional load to the backfill rather than relieving some of the load. This could have implications for a fairly weak CLSM in an in-situ soil mass that will have significant settlements. A fairly weak CLSM with a small trench width might be carrying much more load than is expected because of the interparticle friction of the settling in-situ soil. This could lead to high deflections or even pipe failure if the CLSM is not designed to carry these additional loads. 
Soil Stresses Under Uniform Surcharge Loading recorded in psi

\begin{tabular}{|c|c|c|c|c|c|c|}
\hline & $\begin{array}{l}\text { 10psi (69 } \\
\text { Pa) }\end{array}$ & & \begin{tabular}{|l|}
$20 \mathrm{psi}$ \\
$(138 \mathrm{~Pa})$
\end{tabular} & & \begin{tabular}{|l}
$30 p s i$ \\
$(207 \mathrm{~Pa})$
\end{tabular} & \\
\hline $\begin{array}{l}\text { trench } \\
\text { width } \\
\text { ratio } n_{r}\end{array}$ & $\begin{array}{c}6 \text { inch } \\
\text { pipe }\end{array}$ & $\begin{array}{l}8 \text { inch } \\
\text { pipe }\end{array}$ & $\begin{array}{c}6 \text { inch } \\
\text { pipe }\end{array}$ & $\begin{array}{l}8 \text { inch } \\
\text { pipe }\end{array}$ & $\begin{array}{c}6 \text { inch } \\
\text { pipe }\end{array}$ & $\begin{array}{l}8 \text { inch } \\
\text { pipe }\end{array}$ \\
\hline 1.5 & 14.65 & 10.78 & 21.78 & 16.27 & 28.36 & \\
\hline 2 & 10.22 & 14.42 & 16.16 & 19.82 & 21.21 & 24.35 \\
\hline 2.5 & 17.28 & 10.21 & 31.87 & 15.98 & 40.94 & 20.89 \\
\hline 3 & 11.07 & & 18.62 & & 24.85 & \\
\hline
\end{tabular}
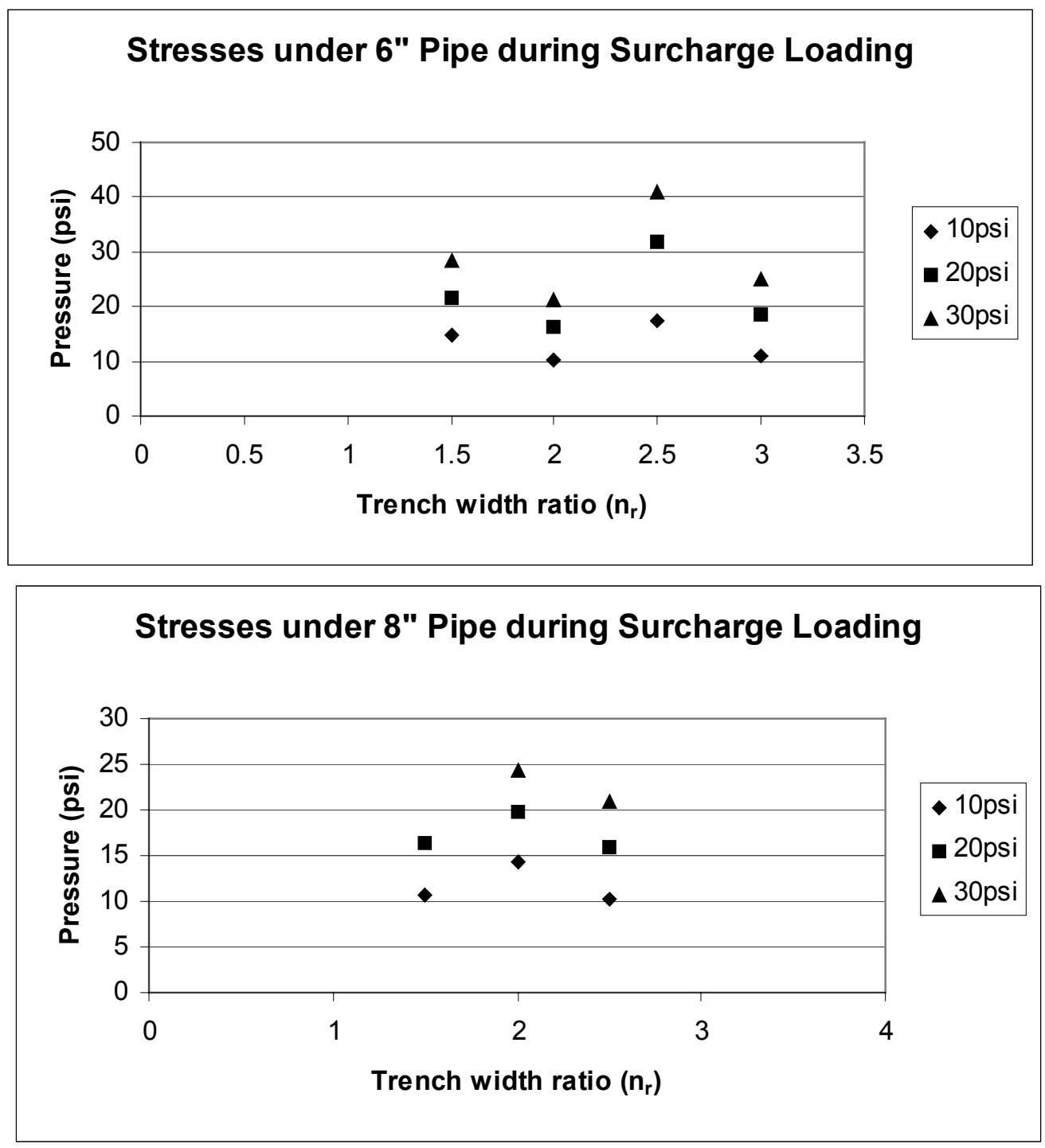

Figure 5.5: Soil Stresses in Cohesive In-Situ Soil With Low Srength Backfill 
Soil Stresses Under Uniform Surcharge Loading recorded in psi

\begin{tabular}{|r|r|r|r|r|r|r|}
\cline { 2 - 7 } \multicolumn{2}{|l|}{} & \multicolumn{1}{l|}{$\begin{array}{l}\text { 10psi }(69 \\
\mathrm{Pa})\end{array}$} & \multicolumn{2}{l|}{$\begin{array}{l}30 \mathrm{psi} \\
(138 \mathrm{~Pa})\end{array}$} \\
\hline $\begin{array}{r}\text { trench width } \\
\text { ratio } \mathrm{n}_{\mathrm{r}}\end{array}$ & $\begin{array}{c}6 \text { inch } \\
\text { pipe }\end{array}$ & $\begin{array}{c}8 \text { inch } \\
\text { pipe }\end{array}$ & $\begin{array}{c}6 \text { inch } \\
\text { pipe }\end{array}$ & $\begin{array}{c}\text { 8 inch } \\
\text { pipe }\end{array}$ & $\begin{array}{c}6 \text { inch } \\
\text { pipe }\end{array}$ & $\begin{array}{c}8 \text { inch } \\
\text { pipe }\end{array}$ \\
\hline 1.5 & 17.39 & 15.66 & 33.12 & 23.79 & & 29.4 \\
\hline 2 & 13.15 & 7.85 & 24.73 & 14.67 & & 19.6 \\
\hline 2.5 & 9.6 & 4.54 & 20.87 & 8.55 & 28.72 & 10.61 \\
\hline 3 & 6.64 & & 16.06 & & 23.03 & \\
\hline
\end{tabular}
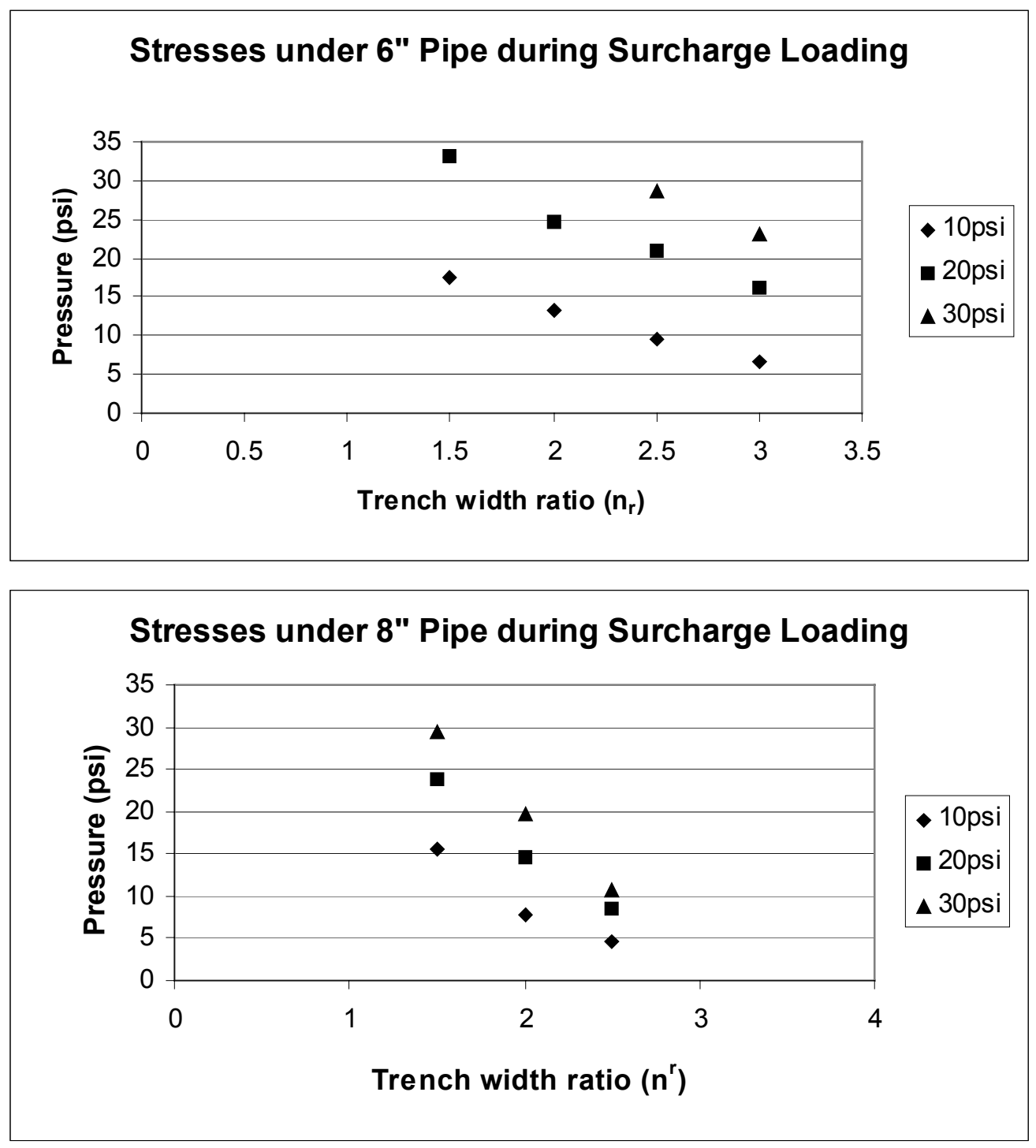

Figure 5.6: Soil Stresses in Cohesive In-Situ Soil With High Strength Backfill 
Soil Stresses Under Uniform Surcharge Loading recorded in psi

\begin{tabular}{|c|c|c|c|c|c|c|}
\hline & $\begin{array}{l}\text { 10psi (69 } \\
\mathrm{Pa})\end{array}$ & & $\begin{array}{l}20 p s i \\
(138 \mathrm{~Pa})\end{array}$ & & $\begin{array}{l}\text { 30psi } \\
(207 \mathrm{~Pa})\end{array}$ & \\
\hline $\begin{array}{l}\text { trench } \\
\text { width } \\
\text { ratio } n_{r}\end{array}$ & $\begin{array}{c}6 \text { inch } \\
\text { pipe }\end{array}$ & $\begin{array}{l}8 \text { inch } \\
\text { pipe }\end{array}$ & $\begin{array}{c}6 \text { inch } \\
\text { pipe }\end{array}$ & $\begin{array}{l}8 \text { inch } \\
\text { pipe }\end{array}$ & $\begin{array}{c}6 \text { inch } \\
\text { pipe }\end{array}$ & $\begin{array}{l}8 \text { inch } \\
\text { pipe }\end{array}$ \\
\hline 1.5 & 10.05 & 10.2 & 15.92 & 16.29 & 20.5 & 21.71 \\
\hline 2 & 11.65 & 10.09 & 18.29 & 15.45 & 24.78 & 19.59 \\
\hline 2.5 & 8.93 & 7.73 & 14.95 & 13.26 & 20.45 & 17.26 \\
\hline 3 & & 7.55 & & 12.13 & & 16.97 \\
\hline
\end{tabular}

\section{Stresses under 6" Pipe during Surcharge Loading}

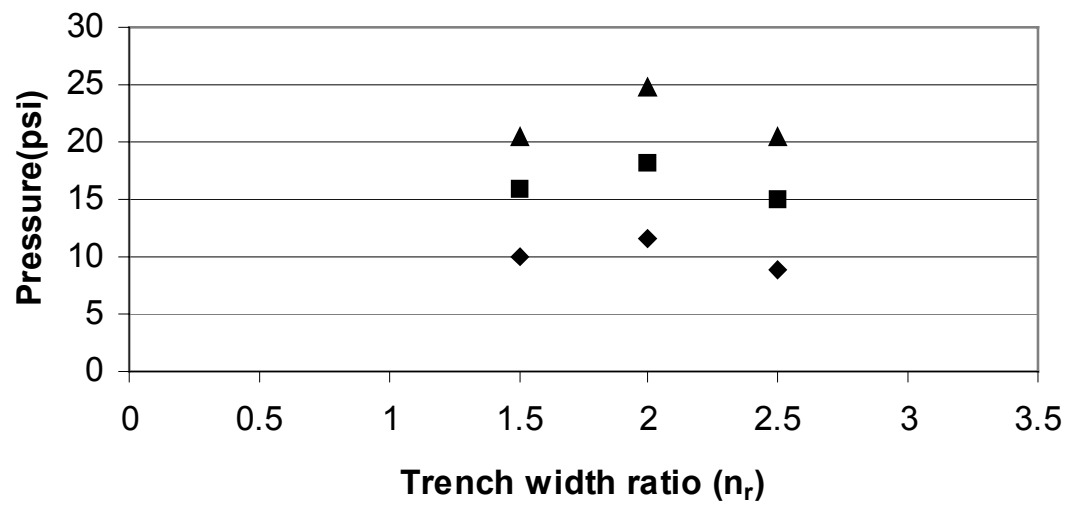

-10psi

\section{Stresses under 8" Pipe during Surcharge Loading}

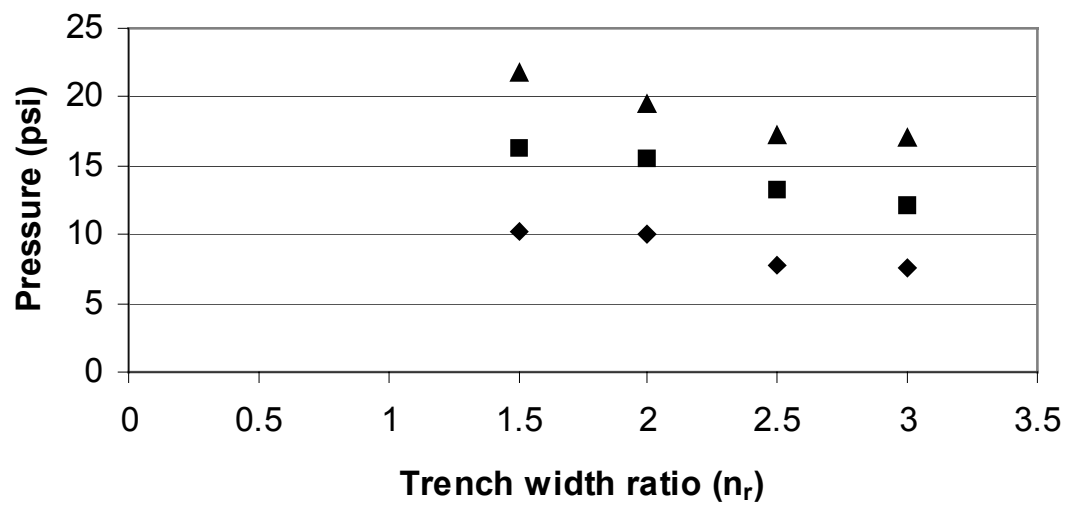

Figure 5.7: Soil Stresses in Loose In-Situ Soil With Low Strength Backfill 
Soil Stresses Under Uniform Surcharge Loading recorded in psi

\begin{tabular}{|c|c|c|c|c|c|c|}
\hline & $\begin{array}{l}\text { 10psi (69 } \\
\text { Pa) }\end{array}$ & & $\begin{array}{l}20 p s i \\
(138 \mathrm{~Pa})\end{array}$ & & $\begin{array}{l}0 p s i \\
(207 \mathrm{~Pa})\end{array}$ & \\
\hline $\begin{array}{l}\text { trench } \\
\text { width } \\
\text { ratio } n_{r}\end{array}$ & $\begin{array}{c}6 \text { inch } \\
\text { pipe }\end{array}$ & $\begin{array}{l}8 \text { inch } \\
\text { pipe }\end{array}$ & $\begin{array}{c}6 \text { inch } \\
\text { pipe }\end{array}$ & $\begin{array}{l}8 \text { inch } \\
\text { pipe }\end{array}$ & $\begin{array}{c}6 \text { inch } \\
\text { pipe }\end{array}$ & $\begin{array}{l}8 \text { inch } \\
\text { pipe }\end{array}$ \\
\hline 1.5 & 16.09 & 9.18 & 26.07 & 15.94 & 36.57 & 21.65 \\
\hline 2 & 11.04 & 15.18 & 20.5 & 26.83 & 27.6 & 32.17 \\
\hline 2.5 & 8.43 & 9.83 & 16.91 & 18.24 & 24.06 & 23.49 \\
\hline 3 & & & & & & \\
\hline
\end{tabular}
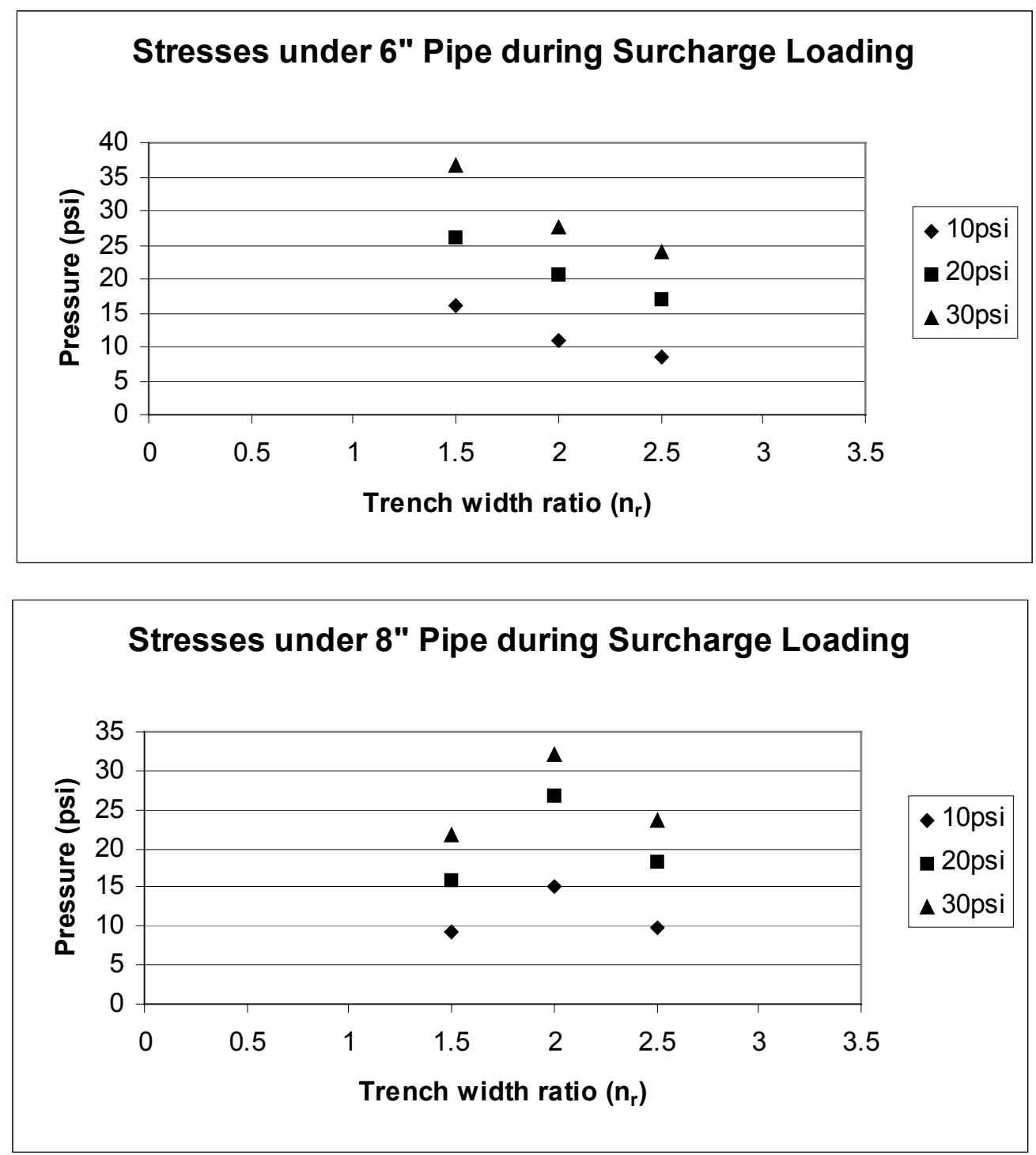

Figure 5.8: Soil Stresses in Loose In-Situ Soil With High Strength Backfill 


\subsection{SOIL STRESSES DUE TO DIRECT LOADING}

Figures 5.9 through 5.12 show the measured centerline soil stresses while direct loading. There are eight graphs with families of curves for loads of 1,000 lb $(4,448 \mathrm{~N})$, $2,000 \mathrm{lb}(8,896 \mathrm{~N})$, and 3,000 lb $(13,344 \mathrm{~N})$ that show the centerline soil stresses versus the trench width ratio. However, this information is not as valuable because of the complex interactions that have occurred before the direct loading took place. Since the direct loading always took place the day after the pressure testing, the centerline stresses and deflections that happen during direct loading depend heavily on the deflections and rebounding that happened during and after the pressure test. As expected, the centerline soil stresses increase as the applied load increases, but these figures primarily show that there is no statistically significant correlation between direct loading, trench widths, and soil stresses. However, one interesting feature is made clear if Figures 5.5 through 5.8 are compared to Figures 5.9 through 5.12. Comparing these figures shows that the measured stresses during direct loading tend to mirror the measured stresses during the surcharge loading. This supports the fact that measurements taken during direct loading depend heavily on the interactions that occurred during the surcharge loading.

\subsection{SUMMARY OF RESULTS}

Table 5.1a shows the maximum and minimum deflections for all experimental configurations while surcharge loading. Table $5.1 \mathrm{~b}$ shows the maximum and minimum soil stresses for all experimental configurations while surcharge loading. Except for one case, the $\mathrm{n}_{\mathrm{r}}$ value corresponding to the maximum deflection was always smaller than the $\mathrm{n}_{\mathrm{r}}$ value corresponding to the minimum deflection. The one exception occurred with a 6 inch $(15.3 \mathrm{~cm})$ pipe with high strength CLSM and cohesive soil, the strongest scenario. In this particular set up the difference between the maximum and the minimum deflections was only a couple hundredths of an inch. Furthermore, the measured deflections were about one-tenth of the measured deflections for tests that used low strength CLSM. This reinforces the statement that larger trench widths have smaller deflections

Except for one case, the $n_{r}$ value corresponding to the maximum soil stress is always smaller than the $\mathrm{n}_{\mathrm{r}}$ value corresponding to the minimum soil stress, as seen in Table 5.1b. This exception occurred when there was a high strength CLSM and loose fill. 
Soil Stresses Under Direct Loading recorded in psi

\begin{tabular}{|r|r|r|r|r|r|r|}
\cline { 2 - 7 } \multicolumn{1}{c|}{} & \multicolumn{1}{l|}{$\begin{array}{l}\text { 1000 lb } \\
(4448 \mathrm{~N})\end{array}$} & \multicolumn{2}{l|}{$\begin{array}{l}3000 \mathrm{lb} \\
(8896 \mathrm{~N}) \\
(13,344 \mathrm{~N})\end{array}$} \\
\hline $\begin{array}{c}\text { trench } \\
\text { width } \\
\text { ratio } \mathrm{n}_{\mathrm{r}}\end{array}$ & 6 inch & 8 inch & 6 inch & 8 inch & 6 inch & 8 inch \\
\hline 1.5 & 8.15 & 5.57 & 10.95 & 6.53 & 14.46 & 6.92 \\
\hline 2 & 7.14 & 8.99 & 9.05 & 10.15 & 11.44 & 10.26 \\
\hline 2.5 & 12.46 & 7.19 & 16.03 & 8.97 & 19.29 & 10.88 \\
\hline 3 & 5.85 & & 7.87 & & 9.59 & \\
\hline
\end{tabular}
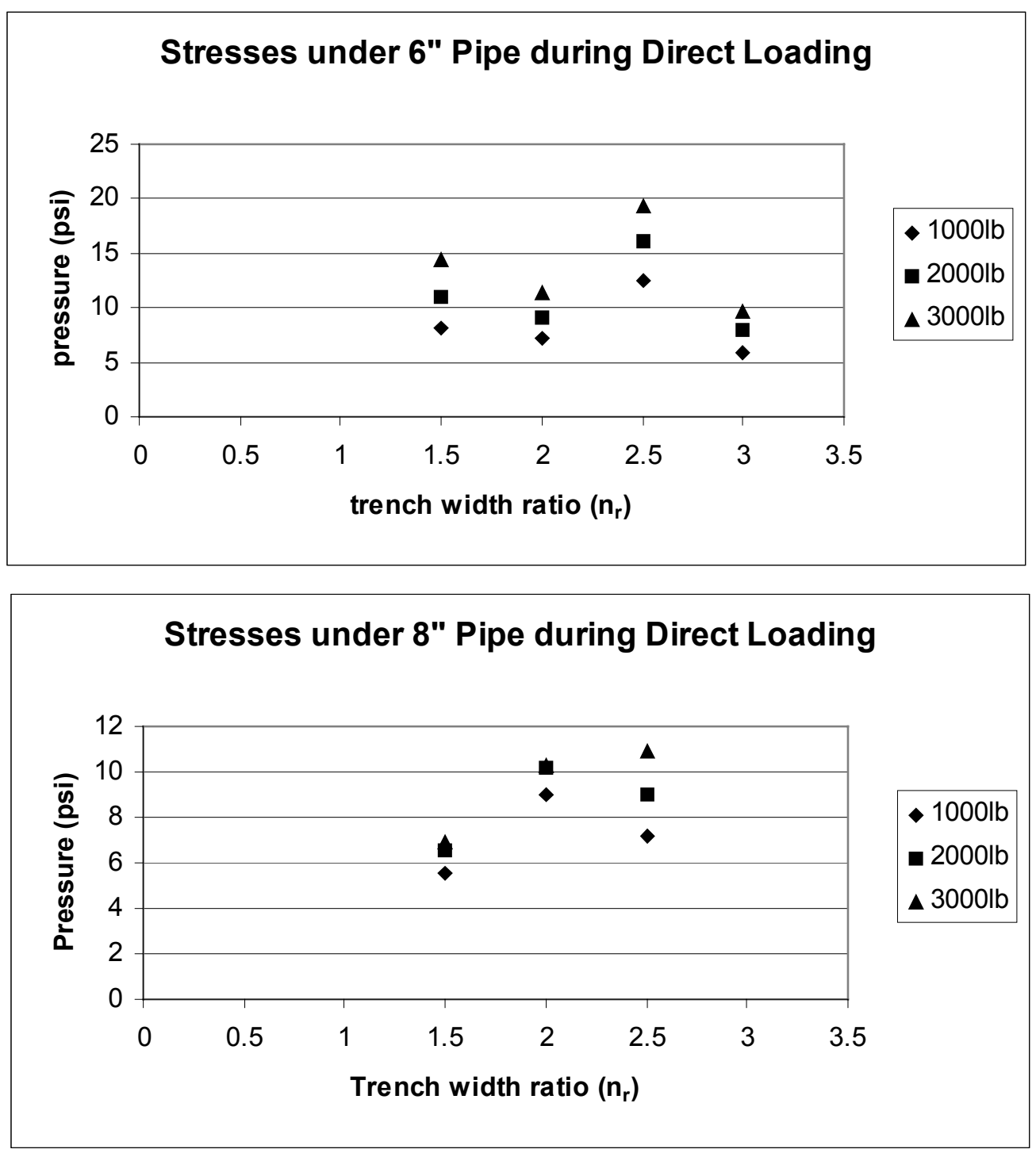

Figure 5.9: Soil Stresses in Cohesive In-Situ Soil With Low Srength Backfill During Direct Loading 
Soil Stresses Under Direct Loading recorded in psi

\begin{tabular}{|c|c|c|c|c|c|c|}
\hline & $\begin{array}{l}1000 \mathrm{lb} \\
(4448 \mathrm{~N})\end{array}$ & & \begin{tabular}{|l|}
$2000 \mathrm{lb}$ \\
$(8896 \mathrm{~N})$
\end{tabular} & & $\begin{array}{l}3000 \mathrm{lb} \\
(13,344 \mathrm{~N}\end{array}$ & \\
\hline $\begin{array}{l}\text { trench } \\
\text { width } \\
\text { ratio } n_{r}\end{array}$ & $\begin{array}{c}6 \text { inch } \\
\text { pipe }\end{array}$ & $\begin{array}{l}8 \text { inch } \\
\text { pipe }\end{array}$ & $\begin{array}{c}6 \text { inch } \\
\text { pipe }\end{array}$ & $\begin{array}{l}8 \text { inch } \\
\text { pipe }\end{array}$ & $\begin{array}{c}6 \text { inch } \\
\text { pipe }\end{array}$ & $\begin{array}{l}8 \text { inch } \\
\text { pipe }\end{array}$ \\
\hline 1.5 & 8.63 & 8.94 & 17.45 & 11.67 & 27.05 & 13.53 \\
\hline 2 & 3.86 & 6.53 & 6.33 & 8.32 & 10.69 & 10.83 \\
\hline 2.5 & & 4.13 & 15.24 & 6.13 & 19.04 & 8.25 \\
\hline 3 & 8 & & 10.67 & & 13.91 & \\
\hline
\end{tabular}
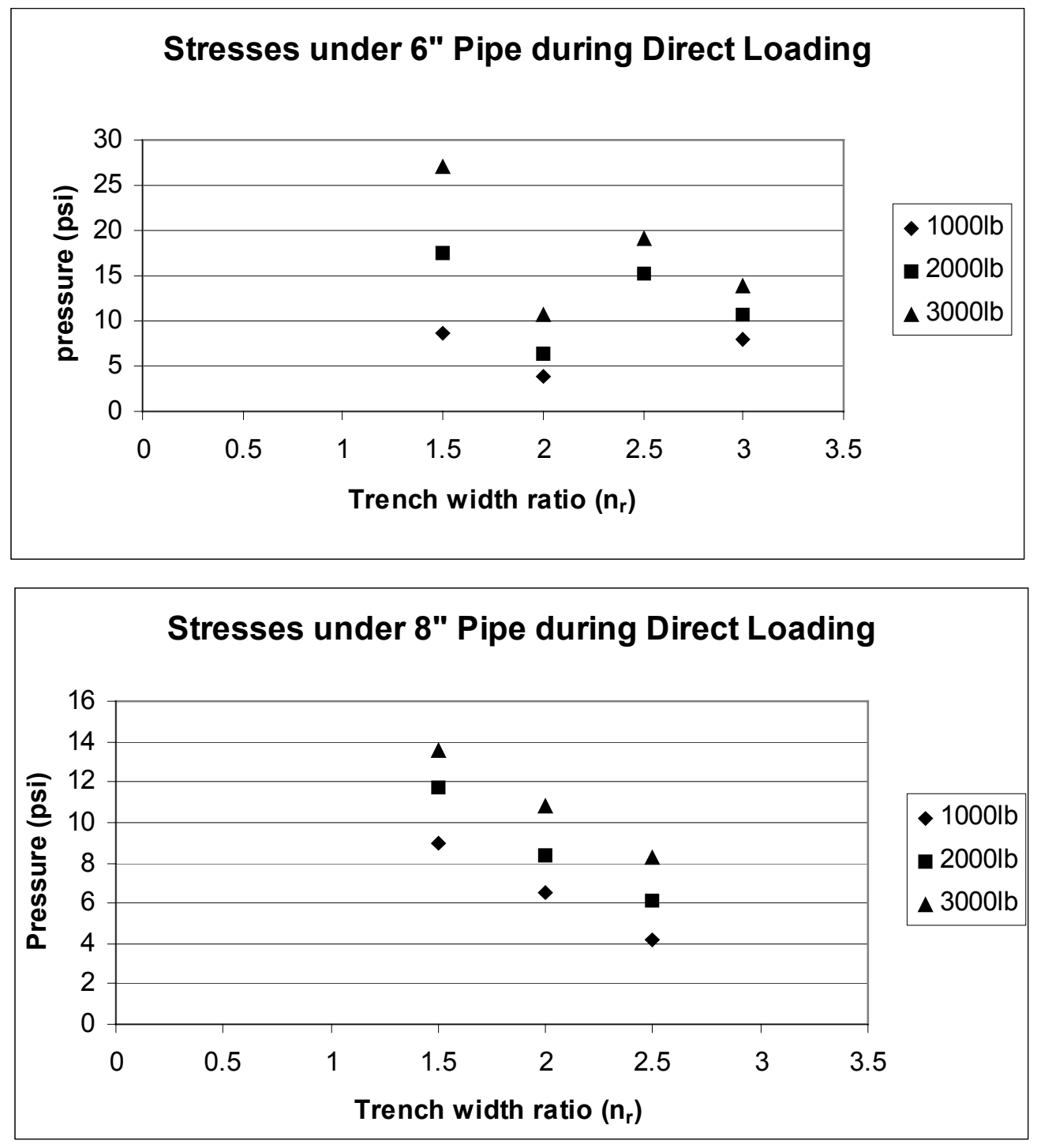

Figure 5.10: Soil Stresses in Cohesive In-Situ Soil With High Strength Backfill During Direct Loading 
Soil Stresses Under Direct Loading recorded in psi

\begin{tabular}{|c|c|c|c|c|c|c|}
\hline & $\begin{array}{l}1000 \mathrm{lb} \\
(4448 \mathrm{~N})\end{array}$ & & \begin{tabular}{|l}
$2000 \mathrm{lb}$ \\
$(8896 \mathrm{~N})$
\end{tabular} & & $\begin{array}{l}3000 \mathrm{lb} \\
(13,344 \mathrm{~N}\end{array}$ & \\
\hline $\begin{array}{l}\text { trench } \\
\text { width } \\
\text { ratio } n_{r}\end{array}$ & $\begin{array}{l}6 \text { inch } \\
\text { pipe }\end{array}$ & $\begin{array}{l}8 \text { inch } \\
\text { pipe }\end{array}$ & $\begin{array}{c}6 \text { inch } \\
\text { pipe }\end{array}$ & $\begin{array}{l}8 \text { inch } \\
\text { pipe }\end{array}$ & $\begin{array}{c}6 \text { inch } \\
\text { pipe }\end{array}$ & $\begin{array}{l}8 \text { inch } \\
\text { pipe }\end{array}$ \\
\hline 1.5 & 6.46 & 3.79 & 8.45 & 5.15 & 9.35 & 6.82 \\
\hline 2 & 4.78 & 5.3 & 7.6 & 6.41 & 9.49 & 6.86 \\
\hline 2.5 & 4.17 & 2.91 & 5.6 & 3.62 & 6.96 & 3.87 \\
\hline 3 & & 2.8 & & 3.6 & & 4.21 \\
\hline
\end{tabular}
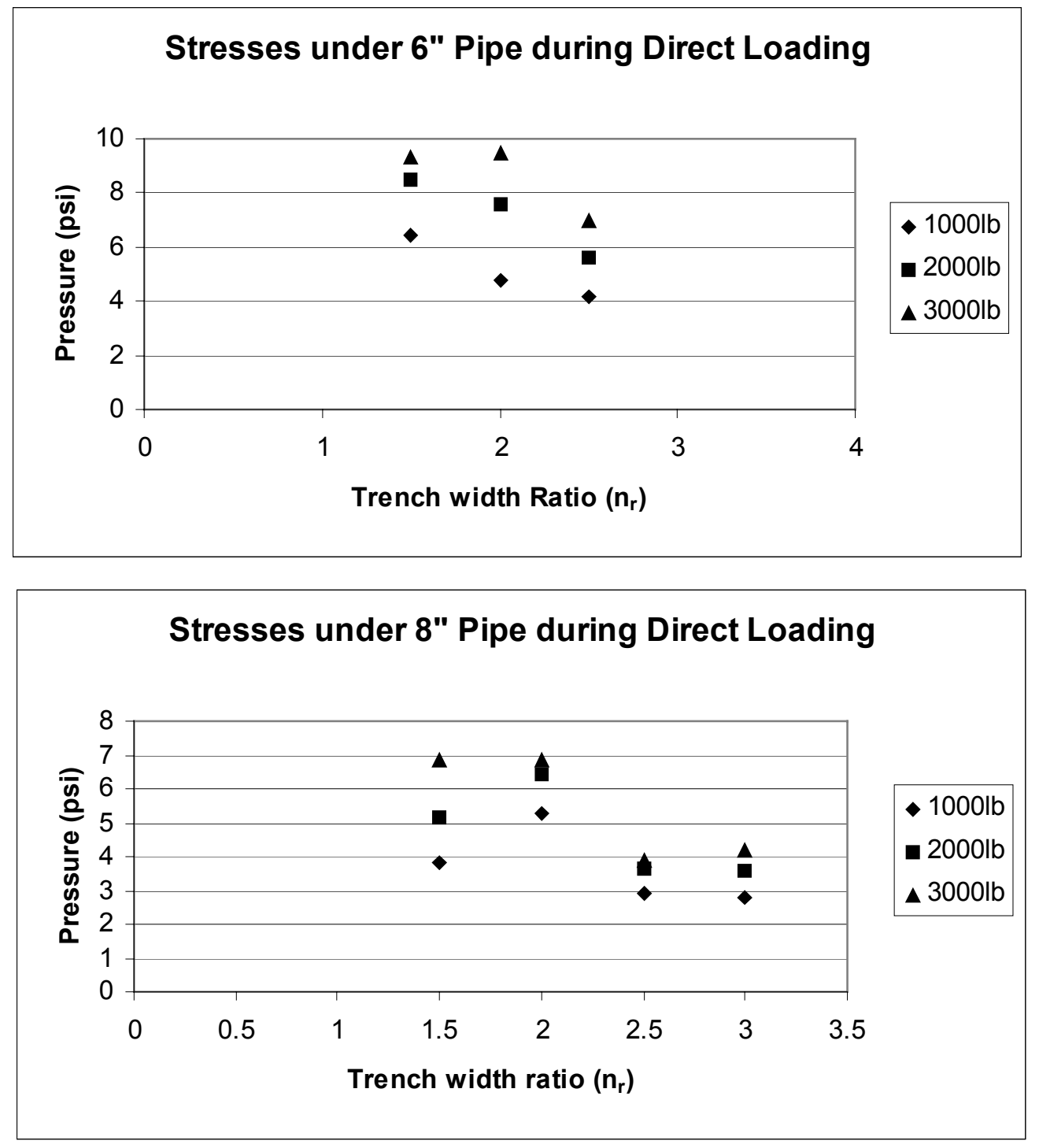

Figure 5.11: Soil Stresses in Loose In-Situ Soil With Low Strength Backfill During Direct Loading 
Soil Stresses Under Direct Loading recorded in psi

\begin{tabular}{|c|c|c|c|c|c|c|}
\hline & $\begin{array}{l}1000 \mathrm{lb} \\
(4448 \mathrm{~N})\end{array}$ & & \begin{tabular}{|l|}
$2000 \mathrm{lb}$ \\
$(8896 \mathrm{~N})$
\end{tabular} & & $\begin{array}{l}3000 \mathrm{lb} \\
(13,344 \mathrm{~N}\end{array}$ & \\
\hline $\begin{array}{l}\text { trench } \\
\text { width } \\
\text { ratio } n_{r}\end{array}$ & $\begin{array}{l}6 \text { inch } \\
\text { pipe }\end{array}$ & $\begin{array}{l}8 \text { inch } \\
\text { pipe }\end{array}$ & $\begin{array}{c}6 \text { inch } \\
\text { pipe }\end{array}$ & $\begin{array}{l}8 \text { inch } \\
\text { pipe }\end{array}$ & $\begin{array}{c}6 \text { inch } \\
\text { pipe }\end{array}$ & $\begin{array}{l}8 \text { inch } \\
\text { pipe }\end{array}$ \\
\hline 1.5 & 9.24 & 8.3 & 13.7 & 11.1 & 18 & 13.07 \\
\hline 2 & 8.61 & 11.85 & 12.65 & 14.99 & 16.88 & 15.4 \\
\hline 2.5 & 9.3 & 8 & 12.51 & 10.74 & 15.5 & 13.59 \\
\hline 3 & & & & & & \\
\hline
\end{tabular}
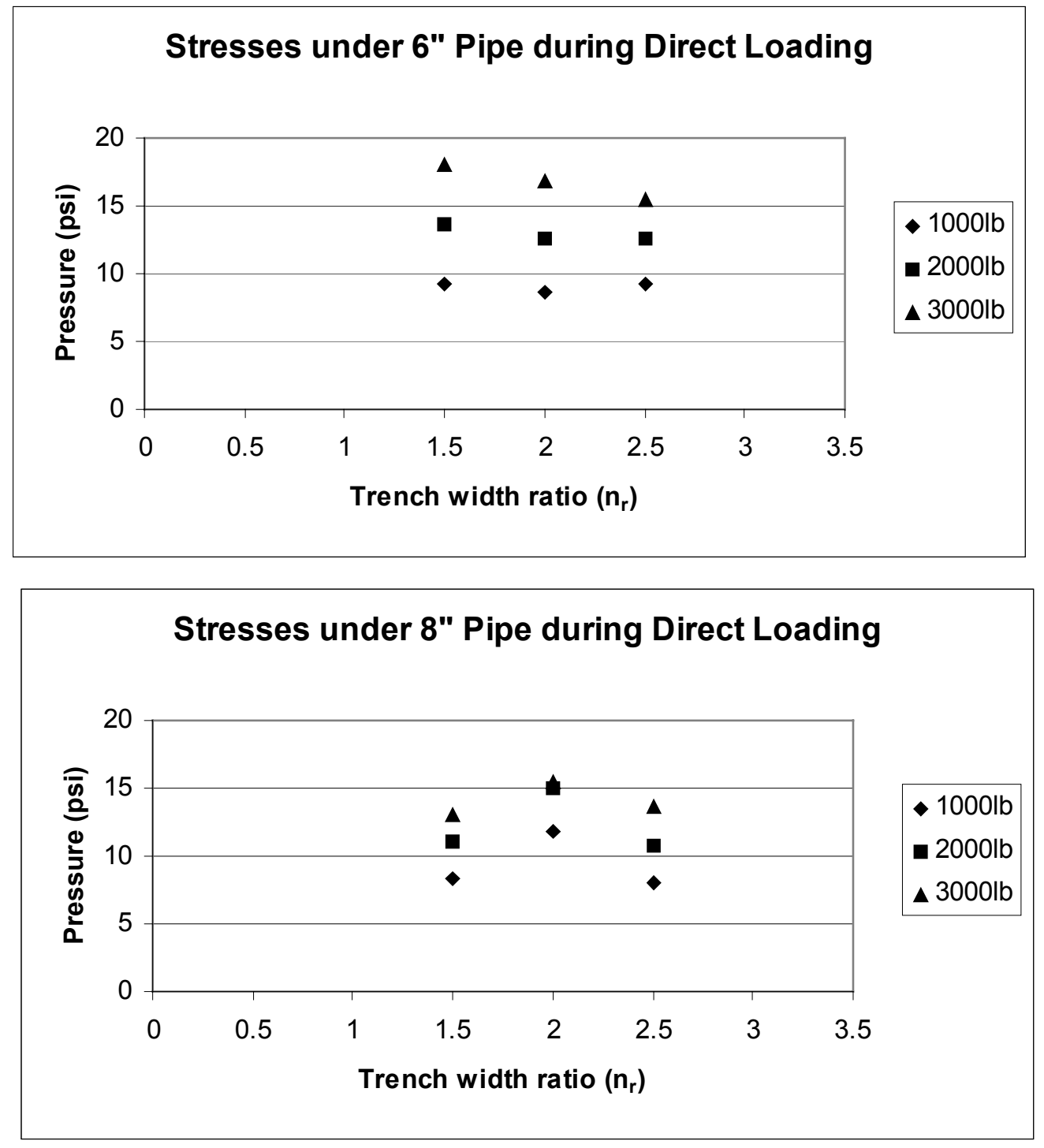

Figure 5.12: Soil Stresses in Loose In-Situ Soil With High Strength Backfill During Direct Loading 
Table 5.1 Summary of Surcharge Loading Maximums and Minimums

a.) Maximum and Minimum Pipe Deflections

\begin{tabular}{|c|c|c|c|c|c|}
\hline $\begin{array}{l}\text { Pipe Diameter } \\
\text { Inch (cm) }\end{array}$ & $\begin{array}{l}\text { CLSM } \\
\text { Strength }\end{array}$ & $\begin{array}{l}\text { In-Situ } \\
\text { Soil Type }\end{array}$ & $\begin{array}{l}\text { Max } \\
\text { Deflection (in) }\end{array}$ & $\begin{array}{l}\text { Min } \\
\text { Defle }\end{array}$ & on (in) \\
\hline $6(15)$ & High & Cohesive & $0.069 \quad \mathrm{n}_{\mathrm{r}}=2$ & 0.028 & $\mathrm{n}_{\mathrm{r}}=1.5$ \\
\hline $6(15)$ & High & Loose & $0.102 \quad \mathrm{n}_{\mathrm{r}}=1.5$ & 0.057 & $\mathrm{n}_{\mathrm{r}}=2$ \\
\hline $6(15)$ & Low & Cohesive & $0.324 \quad \mathrm{n}_{\mathrm{r}}=1.5$ & 0.141 & $\mathrm{n}_{\mathrm{r}}=2.5$ \\
\hline $6(15)$ & Low & Loose & $0.517 \quad \mathrm{n}_{\mathrm{r}}=1.5$ & 0.425 & $\mathrm{n}_{\mathrm{r}}=2$ \\
\hline $8(20)$ & High & Cohesive & $0.482 \quad \mathrm{n}_{\mathrm{r}}=1.5$ & 0.162 & $\mathrm{n}_{\mathrm{r}}=2$ \\
\hline $8(20)$ & High & Loose & $0.143 \quad \mathrm{n}_{\mathrm{r}}=2$ & 0.106 & $\mathrm{n}_{\mathrm{r}}=2.5$ \\
\hline $8(20)$ & Low & Cohesive & Failure $\mathrm{n}_{\mathrm{r}}=1.5$ & 0.217 & $\mathrm{n}_{\mathrm{r}}=2$ \\
\hline $8(20)$ & Low & Loose & $0.629 \quad \mathrm{n}_{\mathrm{r}}=2$ & 0.409 & $\mathrm{n}_{\mathrm{r}}=2.5$ \\
\hline
\end{tabular}

b.) Maximum and Minimum Soil Stresses

\begin{tabular}{|c|c|c|c|c|c|}
\hline $\begin{array}{l}\text { Pipe Diameter } \\
\text { Inch }(\mathrm{cm})\end{array}$ & $\begin{array}{l}\text { CLSM } \\
\text { Strength }\end{array}$ & $\begin{array}{l}\text { In-Situ } \\
\text { Soil Type }\end{array}$ & $\begin{array}{l}\text { Max } \\
\text { Stres }\end{array}$ & ssi) & $\begin{array}{l}\text { Min Soil } \\
\text { Stress (psi) }\end{array}$ \\
\hline $6(15)$ & High & Cohesive & 29.60 & $\mathrm{n}_{\mathrm{r}}=1.5$ & $19.60 \quad n_{r}=2$ \\
\hline $6(15)$ & High & Loose & 32.17 & $\mathrm{n}_{\mathrm{r}}=2$ & $21.65 \quad \mathrm{n}_{\mathrm{r}}=1.5$ \\
\hline $6(15)$ & Low & Cohesive & 24.35 & $\mathrm{n}_{\mathrm{r}}=2$ & $20.89 \mathrm{n}_{\mathrm{r}}=2.5$ \\
\hline $6(15)$ & Low & Loose & 21.71 & $\mathrm{n}_{\mathrm{r}}=1.5$ & $16.97 \quad \mathrm{n}_{\mathrm{r}}=3$ \\
\hline $8(20)$ & High & Cohesive & 33.12 & $\mathrm{n}_{\mathrm{r}}=1.5$ & $16.02 \mathrm{n}_{\mathrm{r}}=3$ \\
\hline $8(20)$ & High & Loose & 36.57 & $\mathrm{n}_{\mathrm{r}}=1.5$ & $24.06 \quad \mathrm{n}_{\mathrm{r}}=2.5$ \\
\hline $8(20)$ & Low & Cohesive & 40.94 & $\mathrm{n}_{\mathrm{r}}=2$ & $21.21 \quad \mathrm{n}_{\mathrm{r}}=2.5$ \\
\hline $8(20)$ & Low & Loose & 24.80 & $\mathrm{n}_{\mathrm{r}}=2$ & $20.50 \quad \mathrm{n}_{\mathrm{r}}=2.5$ \\
\hline
\end{tabular}


This set up would maximize the reverse arching that was discussed in the previous sections because there is a high amount of differential settlement between the weak insitu soil and the strong CLSM. Tables 5.1a and 5.1b also show that while most of the maximum deflections occurred at a trench width ratio of 1.5 , only half of the maximum centerline stresses occurred at a trench width ratio of 1.5. This shows that the maximum deflection and maximum soil stress do not happen under the same conditions. While the smallest trench widths allow the most deflections, the reverse arching is not as pronounced because there is not as much differential settlement between the two soil masses. The centerline soil stress is not necessarily maximized when deflections are maximized. There is not as much difference between the settlements of the in-situ soil and the CLSM at the smallest trench width so the frictional forces between them is not as great.

All of the deflection and centerline soil stress maximums that did not occur at a trench width ratio of 1.5 occurred at trench width ratios of 2.0. As seen in Tables 5.1a and $5.1 \mathrm{~b}$, there was never a case where either the deflections or centerline stresses were maximum at a trench width ratio of 2.5 or 3.0. This is a strong basis to support the fact that both stresses and deflections should decrease as the trench width ratio is increased. While this research shows that the largest trench width ratio consistently performed better than the smaller trench width ratios, all of the trench width ratios adequately supported the pipe.

Table 5.1a shows that only one pipe test out the twenty-six pipe tests conducted had a failure (also shown in figure Figure 5.1). This failed specimen had a large crack form over the centerline of the pipe and two transverse cracks that propagated outward from the springline of the pipe. This effectively broke the hardened column of CLSM into three separate pieces. Most of the low strength CLSM mixtures had small micro cracks form over the centerline of the pipe, but no other visible cracking occurred. Figure 5.13 shows a mixture with micro cracks that did not have a failure. 


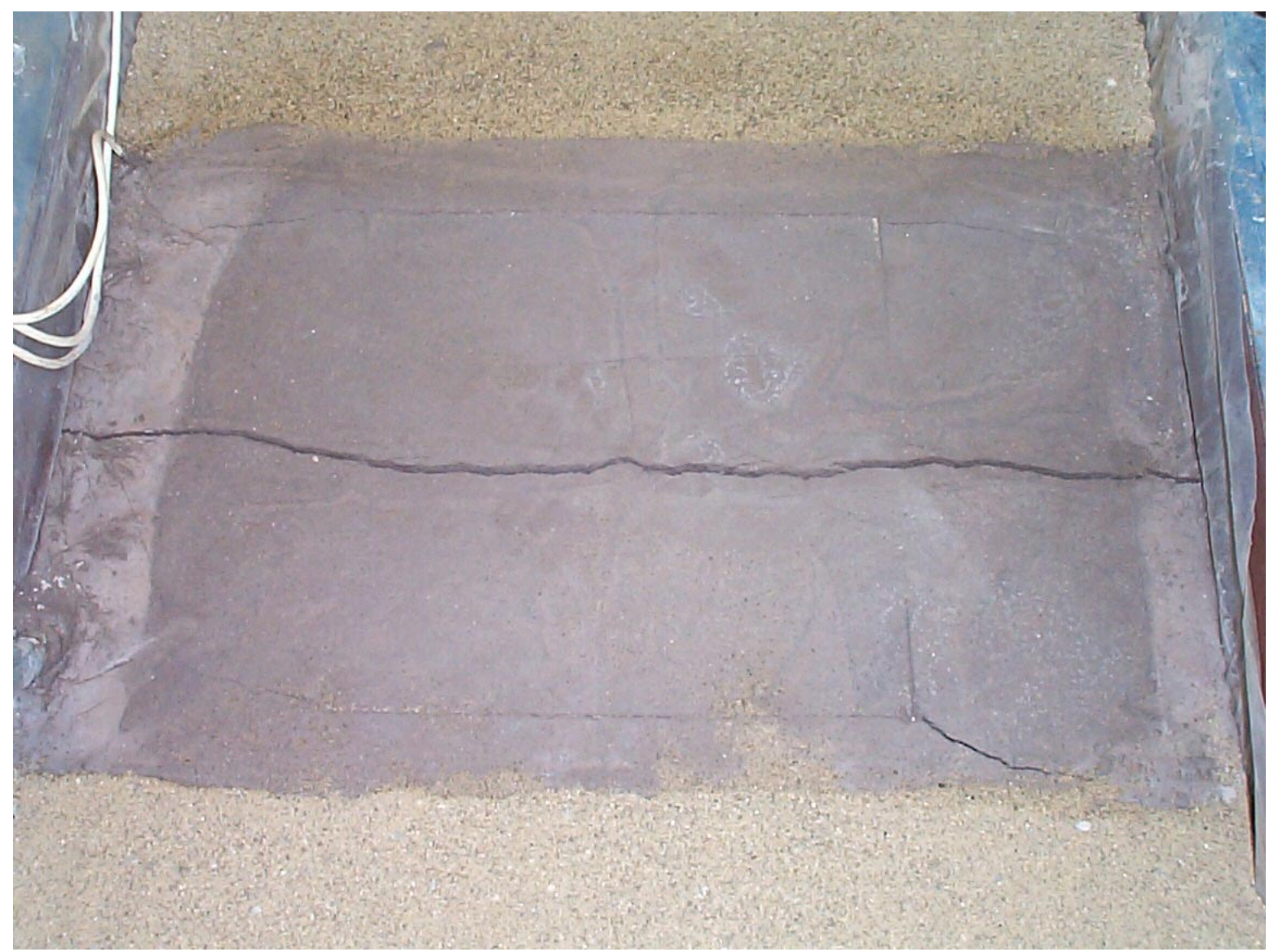

Figure 5.13: CLSM with Micro Cracks Over the Centerline 


\section{CHAPTER 6}

\section{ANALYSIS OF RESULTS}

This chapter involves a numerical analysis and a statistical analysis of the results from pipe testing. Spangler's Iowa equation (Howard 1996) is used to predict pipe deflections and those predictions are compared to the measured pipe deflections. In addition, the measured pipe deflections are used in the Iowa equation to calculate the stiffness of the CLSM. Lastly, the predicted and measured deflections are compared graphically and the correlation of these numbers is discussed.

\subsection{Numerical Analysis}

The form of the Iowa equation that was used in the analysis of the results can be found in Equation 6.1 (Howard 1996). This equation finds the vertical deflection as a percentage of the pipe diameter. To use this equation, one of three rules must be satisfied. The first rule is that the in-situ soil should be as strong as the backfill material or stronger than the backfill material. This rule is certainly not satisfied. The second rule is that the trench width should be at least three times the pipe diameter. Only two of the twenty-six experiments satisfied this rule. The third rule states that if the first two rules are not satisfied then a composite soil stiffness needs to be calculated. Equation 6.2 is the equation used for finding the composite soil stiffness.

$$
\Delta Y=\frac{T_{f}(0.07) \gamma h}{E I / r^{3}+0.061 F_{d} E^{\prime}}
$$

Where,

$$
\begin{array}{ll}
\Delta \mathrm{Y} & =\text { percent vertical deflection } \\
\mathrm{T}_{\mathrm{f}} & =\text { time lag factor } \\
0.07 & =\text { combination of conversion factors including a bedding factor of } 0.1 \\
\gamma & =\text { backfill unit weight, } \mathrm{lb} / \mathrm{ft}^{3} \\
\mathrm{~h} & =\text { depth of cover, } \mathrm{ft} \\
\mathrm{EI} / \mathrm{r}^{3} & =\text { pipe stiffness factor, } \mathrm{psi} \\
0.061 & =\text { constant developed for the Iowa equation }
\end{array}
$$


$\mathrm{F}_{\mathrm{d}} \quad=$ design factor, dimensionless

$\mathrm{E}^{\prime} \quad=$ Modulus of soil reaction, $\mathrm{psi}$

The terms $T_{f}$ and $F_{d}$ are dimensionless. The time lag factor $\left(T_{f}\right)$ varies from 1.5 to 2.5 and is used to account for the plastic stress relaxation that is common in plastic pipes (Gabriel 1998). Since no long-term tests were done in this research, $T_{\mathrm{f}}$ is not needed. The minimum recommended value of 1.5 was used in all of the calculations. The design Factor $\left(F_{d}\right)$ varies from 0.5 to 1 and it can account for how effectively the backfill material is placed. Since CLSM flows into all the void spaces and is much more homogeneous than compacted fill, the $\mathrm{F}_{\mathrm{d}}$ term is always assumed to be 1 for CLSM.

There are two other dimensionless constants, the first one listed (0.07) comes from many conversion factors. Adjusting any of the conversion factors can change this number. One the conversion factors that is commonly adjusted is the bedding factor. A bedding factor value of 0.1 was used, which represents the best type of bedding. The bedding factor accounts for how well the compacted fill supports the haunches of the pipe. Since flowable fill flows around the pipe and fills all voids under the haunches of the pipe, flowable fill always uses a bedding factor of 0.1 . The last unitless constant (0.061) was developed by Spangler to improve the accuracy of this empirical equation. This last constant cannot be changed. All of the unitless constants are derived from using the Iowa equation with English units. To use the equation correctly all of the variables must use the units listed.

The term $(\gamma \mathrm{h})$ is the total vertical stress above the pipe. Since an additional surface loading was applied in the experiments, the applied surface loads were added to the vertical stress. The term EI/ $\mathrm{r}^{3}$ defines the strength of the pipe. Earlier in this report the modulus of elasticity was reported as $94 \mathrm{ksi}(648 \mathrm{kPa})$ and $67.2 \mathrm{ksi}(463 \mathrm{kPa})$ for 6 inch $(15.2 \mathrm{~cm})$ and 8 inch $(20.3 \mathrm{~cm})$ pipes, respectively. The moment of inertia was supplied by the pipe manufacturers as $0.002 \mathrm{in}^{4}\left(0.083 \mathrm{~cm}^{4}\right)$ for the 6 inch $(15.2 \mathrm{~cm})$ pipe and $0.005 \mathrm{in}^{4}\left(0.208 \mathrm{~cm}^{4}\right)$ for the 8 inch $(20.3 \mathrm{~cm})$ pipe. The following pipe stiffness factors $\left(\mathrm{EL} / \mathrm{r}^{3}\right)$ were calculated: $6.96 \mathrm{lb} / \mathrm{in}$ for the 6 inch $(15.2 \mathrm{~cm})$ pipe, and $5.25 \mathrm{lb} / \mathrm{in}$ for the 8 inch $(20.3 \mathrm{~cm})$ pipe. The units on these two pipe stiffness values must be in pounds per inch to work in Equation 6.1. 
The last term, The modulus of soil reaction (E'), has to be a composite value between the CLSM stiffness and the in-situ soil stiffness because the trench widths are less than three diameters for most cases, and the in-situ soil is always weaker than the backfill material. These were the three rules used for applying Spangler's Iowa equation that were discussed earlier in this chapter. The composite modulus of soil reaction can be calculated using Equation 6.2 as (Howard 1996):

$E_{c o m}^{\prime}=S E^{\prime}$

Where,

$E_{c o m}^{\prime}=$ the composite modulus of soil reaction (psi)

$S \quad=$ a reduction factor (unitless)

$E^{\prime} \quad=$ CLSM modulus of soil reaction (psi)

\subsection{PREDICTED DEFLECTIONS}

Table 6.1 shows the values for $E_{c o m}^{\prime}$ that were calculated. The $S$ values were obtained from available literature (Howard 1996). The recommended values for CLSM modulus of soil reaction are 3,000 psi and 25,000 psi for low and high strength CLSM, respectively (Howard 1996). The in-situ soil strength was assumed as 1,000 psi for the loose sand and 2,000 psi for the compacted cohesive soil (Howard 1996). The calculated composite modulus of soil reaction values are used to calculate the predicted deflections.

Table 6.2 shows a comparison between the predicted pipe deflections and the measured pipe deflections. This table shows a close correlation between the measured deflections and the predicted deflections. Figure 6.1 and Figure 6.2 graphically show the correlation between these variables. These figures both show that the predicted deflections are much closer to the measured deflections at smaller values, but as the values increase the measured deflections become much larger than the predicted deflections. This is expected because the Iowa equation has been shown to be less effective when the deflections exceed 5\% (Watkins and Anderson 2000). The two figures show that this relationship can be closely approximated with a parabolic curve. The correlation between the measured displacements and the predicted displacements can be considered as excellent. 
Table 6.1 E'com Values For the Different Geometries

$E^{\prime}$ high strength CLSM $=25,000$ psi (assumed)

E' low strength CLSM $=3,000$ psi (assumed)

$\mathrm{E}_{\mathrm{n}}^{\prime}$ loose sand $=1,000 \mathrm{psi}$

$\mathrm{E}_{\mathrm{n}}^{\prime}$ compacted cohesive soil $=2,000 \mathrm{psi}$

\begin{tabular}{|l|l|r|r|r|r|}
\hline \multicolumn{1}{|c|}{$\begin{array}{c}\text { CLSM } \\
\text { Stiffness }\end{array}$} & soil stiffness & $\mathrm{E}^{\prime}{ }_{\mathrm{n}} / \mathrm{E}^{\prime}$ & $\begin{array}{c}\text { trench width } \\
\text { ratio }\left(\mathrm{n}_{\mathrm{r}}\right)\end{array}$ & \multicolumn{1}{c|}{$\mathrm{S}$} & $\begin{array}{c}\mathrm{E}^{\prime}{ }_{\mathrm{com}} \\
(\mathrm{psi})\end{array}$ \\
\hline high & high & 0.08 & 1.5 & 0.15 & 3,750 \\
\hline high & high & 0.08 & 2 & 0.3 & 7,500 \\
\hline high & high & 0.08 & 2.5 & 0.6 & 15,000 \\
\hline high & low & 0.04 & 1.5 & 0.1 & 2,500 \\
\hline high & low & 0.04 & 2 & 0.23 & 5,750 \\
\hline high & low & 0.04 & 2.5 & 0.55 & 13,750 \\
\hline low & high & 0.66 & 1.5 & 0.75 & 2,250 \\
\hline low & high & 0.66 & 2 & 0.87 & 2,610 \\
\hline low & high & 0.66 & 2.5 & 0.91 & 2,730 \\
\hline low & low & 0.33 & 1.5 & 0.53 & 1,590 \\
\hline low & low & 0.33 & 2 & 0.63 & 1,890 \\
\hline low & low & 0.33 & 2.5 & 0.82 & 2,460 \\
\hline
\end{tabular}


Table 6.2 Predicted and Measured Deflections at 20 psi

\begin{tabular}{|c|c|c|c|c|c|c|}
\hline \multirow{2}{*}{$\begin{array}{c}\text { CLSM } \\
\text { Stiffness }\end{array}$} & \multirow{2}{*}{$\begin{array}{c}\text { soil } \\
\text { stiffness }\end{array}$} & \multirow{2}{*}{$\begin{array}{l}\text { trench } \\
\text { width } \\
\text { ratio }\end{array}$} & \multicolumn{2}{|c|}{8 inch $(20.3 \mathrm{~cm})$ pipe } & \multicolumn{2}{|c|}{6 inch $(15.2 \mathrm{~cm})$ pipe } \\
\hline & & & $\begin{array}{l}\text { Predicted } \\
\text { deflections } \\
\text { (in)-[cm] }\end{array}$ & $\begin{array}{c}\text { Measured } \\
\text { deflections } \\
\text { (in)-[cm] }\end{array}$ & $\begin{array}{c}\text { Predicted } \\
\text { deflections } \\
\text { (in)-[cm] }\end{array}$ & $\begin{array}{l}\text { Measured } \\
\text { deflections } \\
\text { (in)-[cm] }\end{array}$ \\
\hline high & high & 1.5 & $\begin{array}{c}0.105 \\
{[0.267]}\end{array}$ & $\begin{array}{c}0.369 \\
{[0.939]}\end{array}$ & $\begin{array}{c}0.078 \\
{[0.199]}\end{array}$ & $\begin{array}{c}0.028 \\
{[0.071]}\end{array}$ \\
\hline high & high & 2 & $\begin{array}{c}0.053 \\
{[0.135]}\end{array}$ & $\begin{array}{c}0.097 \\
{[0.247]}\end{array}$ & $\begin{array}{c}0.040 \\
{[0.101]}\end{array}$ & $\begin{array}{c}0.069 \\
{[0.175]}\end{array}$ \\
\hline high & high & 2.5 & $\begin{array}{c}0.027 \\
{[0.068]}\end{array}$ & $\begin{array}{c}0.045 \\
{[0.115]}\end{array}$ & $\begin{array}{c}0.020 \\
{[0.051]}\end{array}$ & $\begin{array}{c}0.037 \\
{[0.094]}\end{array}$ \\
\hline high & low & 1.5 & $\begin{array}{c}0.156 \\
{[0.396]}\end{array}$ & $\begin{array}{c}0.064 \\
{[0.165]}\end{array}$ & $\begin{array}{c}0.116 \\
{[0.294]}\end{array}$ & $\begin{array}{c}0.127 \\
{[0.323]}\end{array}$ \\
\hline high & low & 2 & $\begin{array}{c}0.069 \\
{[0.176]}\end{array}$ & $\begin{array}{c}0.037 \\
{[0.096]}\end{array}$ & $\begin{array}{c}0.052 \\
{[0.131]}\end{array}$ & $\begin{array}{c}0.092 \\
{[0.234]}\end{array}$ \\
\hline high & low & 2.5 & $\begin{array}{c}0.029 \\
{[0.074]}\end{array}$ & $\begin{array}{c}0.052 \\
{[0.134]}\end{array}$ & $\begin{array}{c}0.022 \\
{[0.055]}\end{array}$ & $\begin{array}{c}0.067 \\
{[0.170]}\end{array}$ \\
\hline low & high & 1.5 & $\begin{array}{c}0.173 \\
{[0.439]}\end{array}$ & $\begin{array}{c}0.727 \\
{[[1.847]}\end{array}$ & $\begin{array}{c}0.128 \\
{[0.325]}\end{array}$ & $\begin{array}{c}0.225 \\
{[0.574]}\end{array}$ \\
\hline low & high & 2 & $\begin{array}{c}0.150 \\
{[0.380]}\end{array}$ & $\begin{array}{c}0.151 \\
{[0.384]}\end{array}$ & $\begin{array}{c}0.111 \\
{[0.282]}\end{array}$ & $\begin{array}{c}0.152 \\
{[0.387]}\end{array}$ \\
\hline low & high & 2.5 & $\begin{array}{c}0.143 \\
{[0.364]}\end{array}$ & $\begin{array}{c}0.131 \\
{[0.333]}\end{array}$ & $\begin{array}{c}0.106 \\
{[0.270]}\end{array}$ & $\begin{array}{c}0.096 \\
{[0.246]}\end{array}$ \\
\hline low & low & 1.5 & $\begin{array}{c}0.241 \\
{[0.611]}\end{array}$ & $\begin{array}{c}0.416 \\
{[1.057]}\end{array}$ & $\begin{array}{c}0.178 \\
{[0.451]}\end{array}$ & $\begin{array}{c}0.402 \\
{[1.022]}\end{array}$ \\
\hline low & low & 2 & $\begin{array}{c}0.204 \\
{[0.519]}\end{array}$ & $\begin{array}{c}0.455 \\
{[1.156]}\end{array}$ & $\begin{array}{c}0.151 \\
{[0.384]}\end{array}$ & $\begin{array}{c}0.296 \\
{[0.753]}\end{array}$ \\
\hline low & low & 2.5 & $\begin{array}{c}0.158 \\
{[0.403]}\end{array}$ & $\begin{array}{c}0.256 \\
{[0.650]}\end{array}$ & $\begin{array}{c}0.118 \\
{[0.300]}\end{array}$ & $\begin{array}{c}0.335 \\
{[0.852]}\end{array}$ \\
\hline
\end{tabular}




\section{Measured vs. Predicted Deflections}

For Tests on 6" Diameter Pipe

$y=16.646 x^{2}-0.9816 x+0.05$

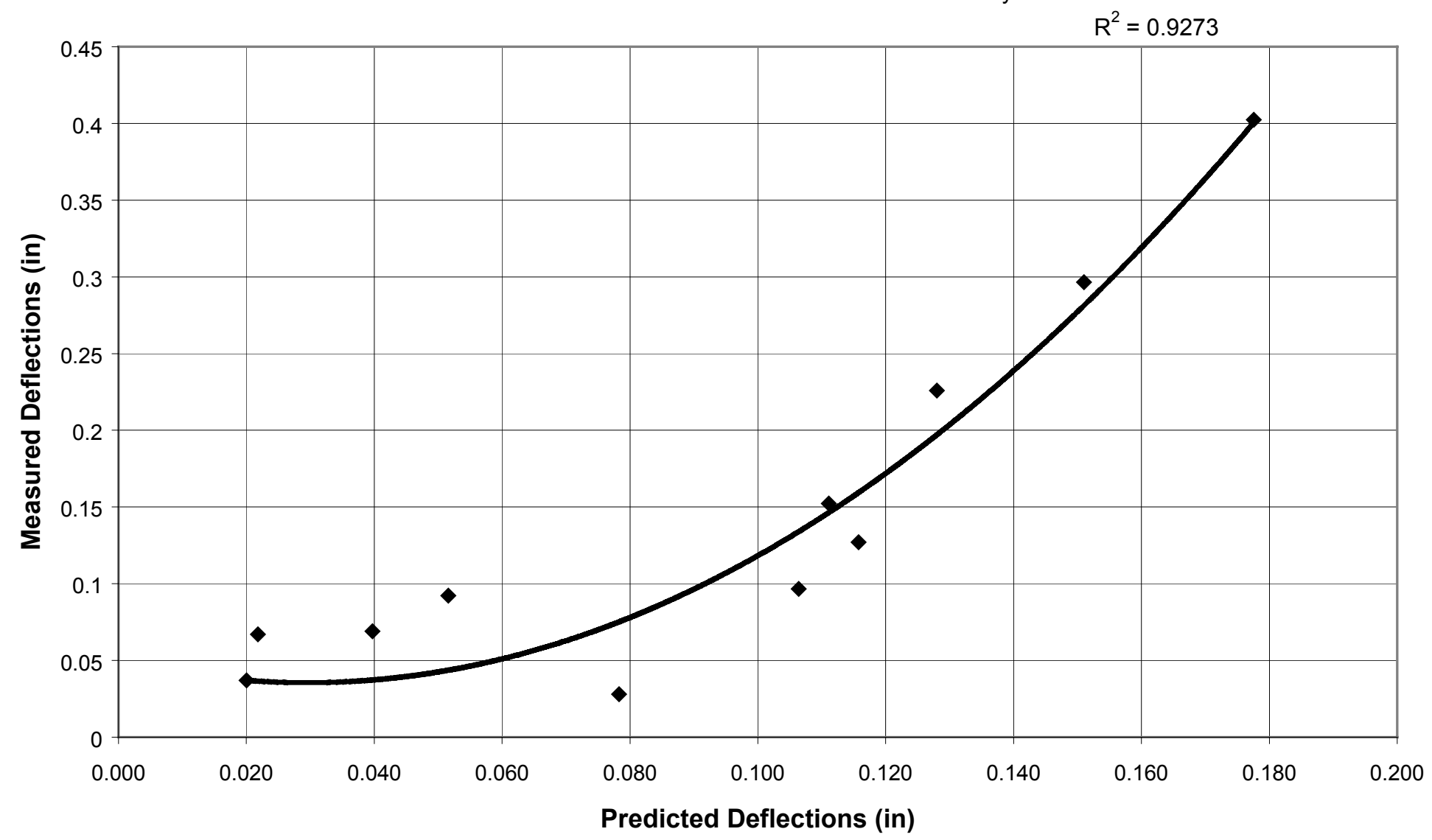

Figure 6.1: Measured versus Predicted Deflections for Tests on 6 inch Pipe 


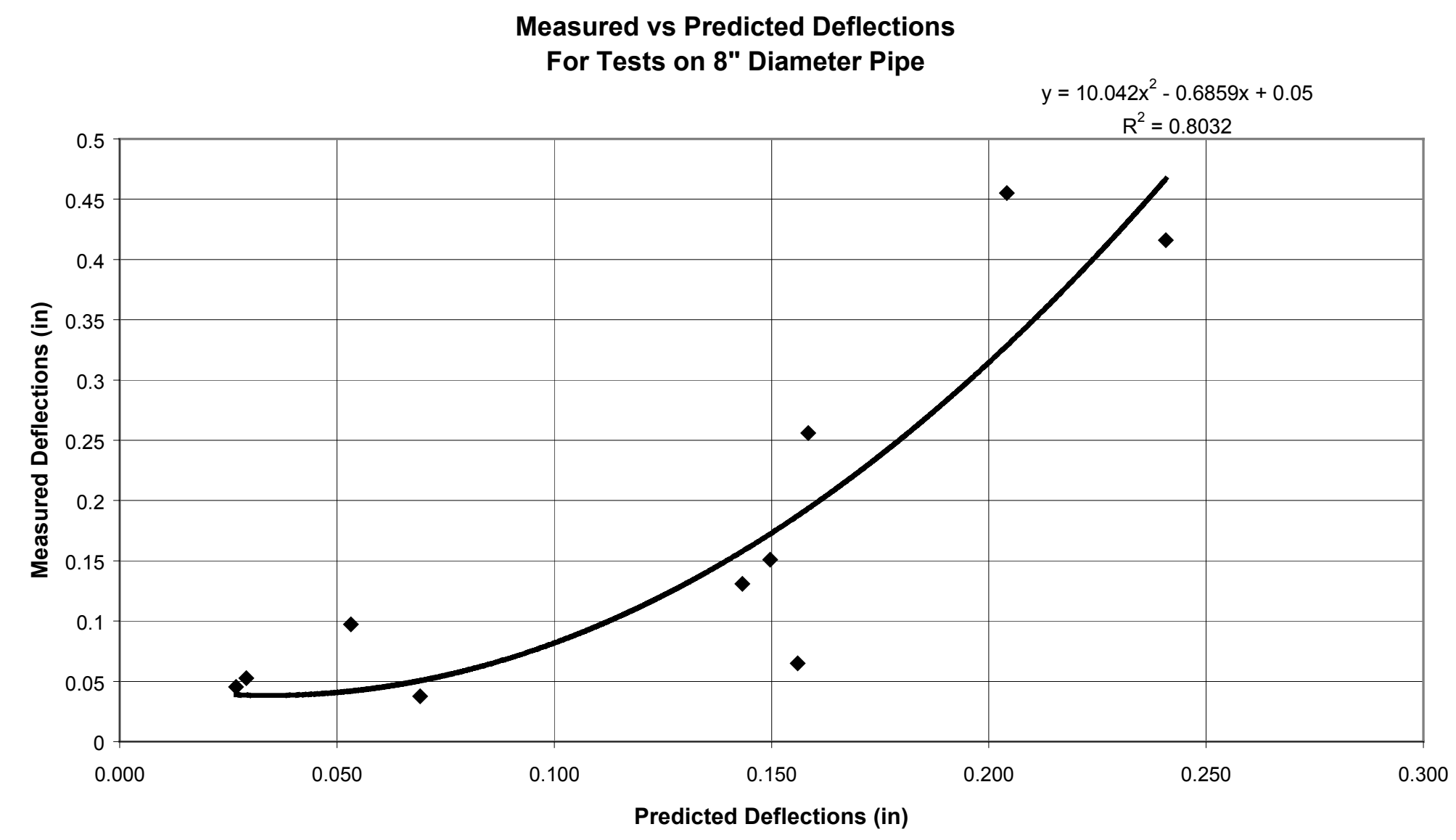

Figure 6.2: Measured versus Predicted Deflections for Tests on 8 inch Pipe 


\subsection{CALCULATED MODULUS OF SOIL REACTION}

The high strength CLSM mixtures tend to have measured deflections that were greater than the predicted values. This is mainly due to the assumed values for the modulus of soil reaction. However, observations in this research can be used to estimate the actual $\mathrm{E}^{\prime}$ values of the two flowable fill mixtures by back calculating in the Iowa equation. The results of these calculations are found in Table 6.3. These calculations show that the low strength CLSM had an average modulus of soil reaction of 3,000 psi $(20,685 \mathrm{~Pa})$, which was the same as the recommended value. The range of backcalculated values fall between 1,000 psi (6895 Pa) and 7,500 psi (51,713 Pa).

The high strength CLSM had slightly higher deflections than the expected values. The back calculated modulus of soil reaction was determined to be 19,200 psi $(132,384$ $\mathrm{Pa})$. This value should be below the recommended value of 25,000 psi (172,375 Pa) since the deflections were greater than expected. The range of back-calculated values for E' fall between 7,000 psi $(48,265 \mathrm{~Pa})$ and 65,000 psi $(448,175 \mathrm{~Pa})$ for all of the high strength CLSM mixtures that did not have failure. The calculated values of $E^{\prime}$ would be useful in setting up a computer simulation of the pipe testing program. 
Table 6.3 Back Calculated Values for E'

\begin{tabular}{|c|c|c|c|c|c|c|c|c|}
\hline \multirow{2}{*}{$\begin{array}{l}\text { CLSM } \\
\text { stiffness }\end{array}$} & \multirow{2}{*}{$\begin{array}{l}\text { soil } \\
\text { stiffness }\end{array}$} & \multirow{2}{*}{$\begin{array}{l}\text { trench } \\
\text { width ratio }\end{array}$} & \multicolumn{3}{|c|}{8 inch $(20.3 \mathrm{~cm})$ pipe } & \multicolumn{3}{|c|}{6 inch $(15.2 \mathrm{~cm})$ pipe } \\
\hline & & & \begin{tabular}{|l|} 
measured \\
deflection (in)
\end{tabular} & $\begin{array}{l}\text { calculated } \\
\text { E'com (psi) }\end{array}$ & $\begin{array}{l}\text { CLSM } \\
\text { (psi) }\end{array}$ & \begin{tabular}{|l|} 
measured \\
deflections (in)
\end{tabular} & \begin{tabular}{|l|} 
calculated \\
E'com (psi)
\end{tabular} & $\begin{array}{l}\text { CLSM } \\
\text { (psi) }\end{array}$ \\
\hline high & high & 1.5 & 0.370 & 1,005 & 1,000 & 0.028 & 10,693 & 66,000 \\
\hline high & high & 2 & 0.097 & 4,060 & 10,000 & 0.069 & 4,271 & 10,000 \\
\hline high & high & 2.5 & 0.045 & 8,801 & 13,000 & 0.037 & 8,064 & 13,000 \\
\hline high & low & 1.5 & 0.065 & 6,130 & 40,000 & 0.127 & 2,268 & 15,000 \\
\hline high & low & 2 & 0.038 & 10,616 & 33,000 & 0.0922 & 3,167 & 10,000 \\
\hline high & low & 2.5 & 0.053 & 7,570 & 12,500 & 0.0671 & 4,395 & 7,000 \\
\hline low & high & 1.5 & 0.727 & 468 & Xxfailure & 0.2259 & 1,225 & 1,200 \\
\hline low & high & 2 & 0.151 & 2,585 & 5,000 & 0.1523 & 1,872 & 1,800 \\
\hline low & high & 2.5 & 0.131 & 2,993 & 7,500 & 0.0967 & 3,015 & 7,500 \\
\hline Iow & low & 1.5 & 0.416 & 883 & 1,000 & 0.4024 & 637 & 1,000 \\
\hline low & low & 2 & 0.455 & 800 & 1,000 & 0.2966 & 906 & 1,000 \\
\hline low & low & 2.5 & 0.256 & 1,489 & 5,000 & 0.3354 & 788 & 1,000 \\
\hline
\end{tabular}

Average E' value for high Strength CLSM $=19,200$ psi $(132,384 \mathrm{~Pa})$

Average E' value for low strength $\mathrm{CLSM}=3,000 \mathrm{psi}(20,685 \mathrm{~Pa})$ 


\section{CHAPTER 7 \\ CONCLUSIONS}

\subsection{CONCLUSIONS}

This report has covered three major sections; mix design of flowable fill, design of a test apparatus, and testing of buried pipes. This research has led to the construction and operation of a laboratory scale pipe testing device that was used for testing the effects of flowable fill around buried pipe.

The section on mix design presents relationships between the percentage of aggregates and the strength and flowability of different mixes. Based on the results, it is possible to find the optimum aggregate content for maximizing strength for different materials. All of the mix designs also showed the point where mixes have segregation problems. Being able to control the strength of CLSM mixes and prevent segregation are two of the most primary concerns in flowable fill mix design. All of these tests show that mixtures that are above $90 \%$ aggregates will have problems with segregation, and the strength is maximized with $50 \%$ to $80 \%$ aggregates. This data provides useful information on CLSM mixes that can be used for transportation projects.

The mix design also showed the relationship of water content and flowabilty. Mixes with high percentage of aggregates require less water to achieve adequate flowability up to the point when segregation becomes a problem. At very high aggregate contents, the water simply separates immediately and the mixture exhibits no flow. Since fly ash is very hydrophylic, higher fly ash content in mixtures will require more water to achieve flowability. Lastly, these tests found that a minimum flow of 6 inches $(15 \mathrm{~cm})$ could be problematic for adequately filling all of the voids, so all pipe tests were conducted with mixtures that had 9 inches $(23 \mathrm{~cm})$ of flow.

One of the objectives of this research was to find mix designs that could maximize the amount of waste material used. All of the fly ash and bottom ash used in this research came from a fluidized bed combustion power plant that burns lower grade high sulfur content coal. The high alkalinity of this ash helps contribute to the pozzolanic activity of the CLSM. Many suitable mix designs were found that would not require any cement and could use as much as $75 \%$ fly ash. The results from the study on mix design shows that mixes containing $100 \%$ waste material in the form of fly ash and bottom ash 
would not form any mixes that would be currently accepted by the WVDOT as class A or class $\mathrm{C}$ mixtures. Since both of these materials are pozzolanic the mixtures have strengths that are in excess of the low strength CLSM, but too small to meet the requirements for high strength CLSM. However, by adding just a little bit of cement mixes composed of primarily bottom ash and fly ash could make suitable high strength CLSM. The high strength CLSM used in the pipe testing in this report used $97 \%$ waste materials and only needed $3 \%$ cement. Cement is an expensive ingredient, so using pozzolonic materials to reduce the required amount of cement is highly desired. Moreover, it was found that CLSM samples cured in water submersion had strength reductions of $12 \%$ to $20 \%$.

The second major section of the report dealt with the design of a testing apparatus. Once the mix design was completed, a laboratory scale device that could test these mixtures was needed. The device that was built did not show any signs of significant deflections or stresses and should be able to carry significantly higher loads than those applied in the course of this research. Both the weight and the cost were successfully minimized. The cost was minimized by using motorcycle inner tubes rather than expensive pressure jacks that would not have given any improvement to the operation of the device. Using deep L-beam reinforcement over thin 1/8 inch $(3.2 \mathrm{~mm})$ sheet metal minimized the weight. The depth of these L-beam flanges provides significant resistance to bending without adding too much weight.

The last section was the laboratory scale pipe testing by using the designed mixtures and the test apparatus. These tests show that both the centerline soil stresses and the deflections are reduced when the trench width ratio is increased. Some attempts have been made to quantify these relationships but there is an inadequate number of tests for the results to be statistically significant. These tests have provided a strong foundation for further research to fully investigate the relationship of these variables.

High strength CLSM led to less deflection than low strength CLSM. High strength cohesive soil led to less deflection than did loose cohesionless soil. Smaller pipes deflect less than larger pipes, and larger loads produce greater deflections and pressures than smaller loads. These results are consistent with expected trends.

One interesting result was shown by the high centerline soil stress induced from having a high strength CLSM in conjunction with a low strength in-situ soil. As 
explained by arching theory, differential settlements in two soil masses will cause the transfer of loads from one soil mass to the other in the form of interparticle friction. This relationship, as well as all the other interparticle soil forces and soil-to-pipe reactions can be made into statistically significant relationships with the inclusion of additional testing.

The final portion of the research was the numerical analysis. The numerical analysis using Spangler's Iowa formula was completed. This analysis showed that the deflections can be reasonably predicted as long as there is accurate information on the soil stiffness. The analysis showed that the high strength CLSM had an average modulus of soil reaction of 19,200 psi (132 $\mathrm{kPa})$ with vales that ranged from 1,000 psi (6,900 $\mathrm{Pa})$ to $66,000 \mathrm{psi}(448 \mathrm{kPa})$. The low strength CLSM had an average modulus of soil reaction of $3,000 \mathrm{psi}(20,700 \mathrm{~Pa})$ with values that ranged from $1,000 \mathrm{psi}(6,900 \mathrm{~Pa})$ to $7,500 \mathrm{psi}$ (51,700 Pa). Design manuals (Howard 1996) often suggest using 3,000 psi (20,700 Pa) for low strength CLSM and 25,000 (172 kPa) for high strength CLSM. In addition, the correlations between the measured displacements and the predicted displacements can be considered as excellent. As with the other tests, this information could be improved if more tests were conducted.

The results of the pipe testing showed a good performance for all trench width ratios. At a trench width ratio of 1.5 , only one out of eight tests had greater than $7 \%$ deflection when 20 psi (138 Pa) surcharge loading was applied. The results of this research show narrow trench widths can be successfully used in many cases if the in-situ soil strength and the CLSM strength are appropriately accounted for.

\subsection{RECOMMENDATIONS FOR FURTHER RESEARCH}

As stated earlier, more pipe testing should be done to find statistically significant relationships between all the control variables. The following is a list of specific experimental sequences that would generate useful results.

- Conduct tests on 10 inch $(25 \mathrm{~cm})$ and 12 inch $(30 \mathrm{~cm})$ pipe diameters. This will give a full range of pipe diameters for comparative purposes.

- Conduct tests using an even lower strength CLSM and an intermediate WVDOT Class B mixture. The low strength CLSM that was used in this research falls near the top of the required low strength range. These additional 
tests will provide a fuller range of strength values for the CLSM mixtures as well as help to establish the relationships between CLSM strength, in-situ soil strength, and centerline soil stress beneath the pipe.

- Conduct tests with various depths of cover. All of these tests used the same depth of cover, but this could easily be an additional variable for further research.

- Conduct long term loading tests. In all of the tests conducted in this research pressure was immediately removed. Applying a set pressure for several days or weeks could lead to valuable information on stress relaxation in the pipe and creep behavior of the CLSM. 


\section{REFERENCES}

1. ACI 229R-99. (1999) “Controlled Low strength Materials (CLSM).” American Concrete Institute, Farmington Hills, Michigan.

2. ASTM D 2412. (2000) "Standard Test Method for Pipe Stiffness." American Standards for Testing Materials.

3. ASTM D 4832. (2000) "Standard Test Method for preparation and testing of controlled low strength materials test cylinders." American Standards for Testing and Materials.

4. ASTM D 5435. (2000) "Fly Ash Testing." American Standards for Testing and Materials.

5. ASTM D 6103. (2000) "Standard Test Method for flow consistency of controlled low strength materials." American Standards for Testing and Materials.

6. ASTM D 6023. (2000) "Standard Test Method for unit weight, Yield, cement content, and air content of controlled low strength materials." American Standards for Testing and Materials.

7. Bhat, S.T., and C.W. Lovell. (1996) "Design of flowable fill: Waste foundry sand as a fine aggregate." Transportation Research Record. V 1546. 70-78.

8. Bhat, S.T., and C.W. Lovell. (1998) "Mix design for flowable fill." Transportation Research Record. V 1589. 26-28 
9. Brewer, W. E., Hurd, J. O. (1993) "Controlled Low Strength Material - Controlled Density Fill (CLSM - CDF) as a Backfill around flexible Structures." Structural Performance of Pipes '93. Proceedings of the Second Conference on Structural Performance of Pipes. 25-34

10. Brewer, W. E. (1990) "The Design and Construction of culverts using Controlled Low Strength Material - Controlled Density Fill (CLSM - CDF) Backfill." Structural Performance of Flexible Pipes. Proceedings of the First National Conferenceon Flexible Pipes. 109-118

11. Brinkley, D., Mueller, P. E. (1998) "Ten Year Performance Record of Non-Shrink Slurry Backfill." ASTM Special Technical Report n1331. 231-236

12. Bulson, P. S. (1985) "Buried Structures: Static and Dynamic Strength." Chapman \& Hall, New York, NY.

13. D’Andria, Gilberto G., J. David Frost, Alaa Ashmawy, And Kyle R. Patterson. (1998) "Potential factors affecting flow consistency test method for controlled low strength materials." Transportation Research Record. V 1589. 29-35

14. Daniels, L. H. (1990) "Structural Stability of Deflected Flexible Pipe in a Backfilled Trench." Structural Performance of Flexible Pipes. Proceedings of the First National Conferenceon Flexible Pipes. 119-122

15. "Dynamic response of pipelines buried in back filled trenches." (1991) Journal of pressure vessel technology. Transactions of the ASME v113 n3. 429-436

16. Gabriel, L. H. (1998) “When Plastic Pipe Responds - Relax and Enjoy." Structural Performance of Pipes '98, Proceedings of the Third Conference on Structural Performance of Pipes. 27-38 
17. Gandham, S., K. Seals, and Paul T, Foxworthy (1996) "Phosphogypsum as a component of Flowable Fill." Transportation Research Record. V 1546. 79-87

18. Gray, D. et all. (1998) "Filling Abandoned Mines With Fluidized Bed Combustion Ash Grout." ASTM Special Technical Report n1331. 180-194

19. Hegerty, J. R., and Eaton, S. J. (1998) "Flowable Fill Promotes Trench Safety and Supports Drainage Pipe Buried 60 ft. (18.3 m) Under New Runway" ASTM Special Technical Report n1331. 255-264

20. Hibbeler, R. C. (1997) “Mechanics of Materials.” Prentice Hall; Upper Saddle River, NJ.

21. Hitch, J.L. (1998) "Test Method for CLSM: Past Present and Future."

22. Hook, W., Clem, D. A. (1998) "Innovative Uses of CLSM in Colorado." ASTM Special Technical Report n1331. 137-150

23. Howard, A. (1996) “Pipeline Installation.” Relativity Publishing, Lakewood, CO.

24. Howard, A. (1998) "Proposed Standard Practice for Installing Buried Pipe Using Flowable Fill.” ASTM Special Technical Report n1331. 285-295

25. Howard, J. R. (1983) "Fluidized Beds Combustion and Applications." Applied Science Publishers, London, England. 1-76

26. Kassimali, Aslam (1995). "Structural Analysis." PWS Publishing Company; Boston, MA. 
27. Katona, M. G., Smith, J. M., Odello, R. S., and Allgood, J. R. (1976). “CANDE - A Modern Approach for the Structural Design and Analysis of Buried Pipes." FHWARD-77-5. Federal Highway Administration. Washington, DC.

28. Landwermeyer J. S., Rice, E. K. (1999) "Comparing Quick-Set and Regular CLSM.” Concrete International. 34-39

29. McGrath, T. J., Hoopes, R. J. (1998) “Bedding Factors and E' Values for Buried Pipe Installation Backfilled with Air-Modified CLSM." ASTM Special Technical Report n1331. 265-274

30. Monson, Tonya. (1997) "Engineering properties of controlled low-strength material using fly ash-AMD sludge." West Virginia University, College of Engineering and Mineral Resources Thesis.

31. Mullarky, J.I. (1998) “Long Term Strength Gain of CLSM.” ASTM Special Technical Report n1331. 102-107

32. "PCI Design Handbook: Precast and Prestressed Concrete $5^{\text {th }}$ ed." (1999) Precast/Prestressed Concrete Institute; Chicago, IL.

33. Petroff, L. J. (1993) "Ring Bending Stiffness and the Design of Flexible Pipe." Structural Performance of Pipes '93. Proceedings of the Second Conference on Structural Performance of Pipes.125-136

34. "The Procedure Handbook of Arc Welding." (1973) The Lincoln Electric Company; Clevland $\mathrm{OH}$.

35. Ramme, B. W. (1999). "Progress in CLSM: Continuing Innovation.” Concrete International. 32-33 
36. Snethen, Donald R., and Benson J. M. (1998) "Construction of CLSM Approach to Minimize the Bump at the End of the Bridge." ASTM Special Technical Report n1331. 265-274

37. Sullivan R. W. (1999) “Boston Harbor Tunnel Project Utilizes CLSM.” Concrete International. May. 40-43

38. "Standard Specifications Roads and Bridges." (2000). West Virginia Division of Highways.

39. Vipulanandan, C., Wang, Y., and Zhang, C. (1998). "Recycled Materials in Geotechnical Applications, Proceedings of the Geo-Congress.” Oct. 18-21. Boston, Ma. 137-152

40. Watkins, R. K., Anderson, L. R. (2000) "Structural Mechanics of Buried Pipes." CRC Press, Washington, D.C.

41. Webb, M.C., McGrath T. J., and Selig, E. T. (1998) "Field Test of Buried Pipe with CLSM Backfill.” ASTM Special Technical Report n1331. 237-254

42. Zaman, M. and Laguros, J. G. (1990) "Predicting the Behavior of Buried Pipes Using Finite Element Approach." Structural Performance of Pipes: Proceedings of the First National Conference on Flexible Pipes. Columbus, Oh. 163-170

43. Ziemkiewicz, P. F., and Black, C. (2000) "Disposal and Use of Coal Combustion Products in Mined Environments." Proceedings of the Fifth International Conference on Acid Mine Drainage. Denver, Co. 1261-1269 


\section{VITA}

I was born and raised in California. When my Grandfather died, I moved to Garrett County Maryland to be the caretaker of a beautiful piece of family property. I graduated with Honors from Garrett Community College, receiving an Associate's Degree in Math and Natural Science in 1996. Garrett community college is also where I met the woman who would eventually become my wife. After graduating I spent one year as a volunteer for the American Conservation Corps.

I transferred to West Virginia University the following year. While studying for my Bachelor's Degree in Civil and Environmental Engineering I married my loving companion. I received my Bachelor's Degree in 1999, graduating with high honors. Since graduating my wife and I were blessed with a beautiful baby boy. I have been working diligently to receive my Master's of Science Degree while learning to be a father. 


\section{Appendix A \\ Data Collected From Flowability Testing}




\section{Flowability Data:}

Mix: M: $100 \%$ fly ash

\begin{tabular}{|lc|r|r|r|r|}
\hline Container & 5 & 6 & 7 & 2 \\
\hline Mass c. & $(\mathrm{g})$ & 32.37 & 32.83 & 28.73 & 25.91 \\
\hline mass full & $(\mathrm{g})$ & 107.6 & 131.57 & 131.57 & 130.73 \\
\hline mass dry & $(\mathrm{g})$ & 74.8 & 88.14 & 85.93 & 82.84 \\
\hline W & & 77.30379 & 78.52106 & 79.79021 & 84.12085 \\
\hline Spread (inch) & 6.5 & 7.5 & 9 & 9.5 \\
\hline
\end{tabular}

Mix: M1C: $99 \%$ fly ash, $1 \%$ cement

\begin{tabular}{|lc|r|r|r|r|}
\hline Container & 8 & 10 & 11 & 13 \\
\hline Mass c. & $(\mathrm{g})$ & 28.66 & 27.8 & 27.49 & 28.04 \\
\hline Mass full & $(\mathrm{g})$ & 123.82 & 118.5 & 131.38 & 126.13 \\
\hline Mass dry & $(\mathrm{g})$ & 83.18 & 78.9 & 85.13 & 82.33 \\
\hline W & 74.54145 & 77.49511 & 80.23942 & 80.67784 \\
\hline Spread (inch) & 6 & 7.625 & 9.375 & 9.875 \\
\hline
\end{tabular}

Mix: M3C: $97 \%$ fly ash, $3 \%$ c

\begin{tabular}{|c|c|c|c|c|}
\hline Container & 1 & 3 & 31 & 20 \\
\hline Mass c. & 30.84 & 36.11 & 36.32 & 36.6 \\
\hline Mass full & 117.03 & 145.35 & 148.14 & 155.82 \\
\hline Mass dry & 80.02 & 97.87 & 98.7 & 102.74 \\
\hline W & 75.25417 & 76.87824 & 79.25617 & 80.25401 \\
\hline Spread (inch) & 6 & 7.25 & 9.25 & 10.375 \\
\hline
\end{tabular}

Mix: M6C: $94 \%$ fly ash, $6 \%$ cement

\begin{tabular}{|lc|r|r|r|r|}
\hline Container & 24 & 29 & 33 & 38 \\
\hline Mass c. & $(\mathrm{g})$ & 36.42 & 36.53 & 36.59 & 36.47 \\
\hline Mass full & $(\mathrm{g})$ & 127.76 & 142.16 & 131.48 & 137.38 \\
\hline Mass dry & $(\mathrm{g})$ & 89.05 & 96.28 & 89.99 & 92.8 \\
\hline W & & 73.55121 & 76.78661 & 77.69663 & 79.14078 \\
\hline Spread (inch) & 6.125 & 8 & 8.75 & 9.625 \\
\hline
\end{tabular}


Mix: M5BA: $95 \%$ fly ash, $5 \%$ bottom ash

\begin{tabular}{|lc|r|r|r|r|}
\hline Container & 7 & 17 & 10 & 18 \\
\hline Mass c. & $(\mathrm{g})$ & 31.14 & 27.64 & 27.61 & 26 \\
\hline Mass full & $(\mathrm{g})$ & 108.6 & 111.8 & 134.42 & 121.45 \\
\hline Mass dry & $(\mathrm{g})$ & 77.6 & 77.36 & 89.15 & 80.27 \\
\hline W & 66.72406 & 69.2679 & 73.56191 & 75.87986 \\
\hline Spread (inch) & 4.875 & 6.125 & 8.125 & 9.625 \\
\hline
\end{tabular}

Mix: M10BA: $90 \%$ fly ash, $10 \%$ bottom ash

\begin{tabular}{|lc|r|r|r|r|}
\hline Container & 1 & 8 & 5 & 11 \\
\hline Mass c. & $(\mathrm{g})$ & 33.58 & 27.74 & 30.61 & 27.68 \\
\hline Mass full & $(\mathrm{g})$ & 121.71 & 118.21 & 109.22 & 125.18 \\
\hline Mass dry & $(\mathrm{g})$ & 86.59 & 80.57 & 76.15 & 83.73 \\
\hline W & 66.25165 & 71.2474 & 72.61748 & 73.95183 \\
\hline Spread (inch) & 4.875 & 7.5 & 9.25 & 9.875 \\
\hline
\end{tabular}

Mix: M25BA: $75 \%$ fly ash, $25 \%$ bottom ash

\begin{tabular}{|lc|r|r|r|r|}
\hline Container & 24 & 31 & 30 & 33 \\
\hline Mass c. & $(\mathrm{g})$ & 36.62 & 36.82 & 36.45 & 36.69 \\
\hline Mass full & $(\mathrm{g})$ & 137.91 & 158 & 140.38 & 158.42 \\
\hline Mass dry & $(\mathrm{g})$ & 99.34 & 110.49 & 99.19 & 110.17 \\
\hline W & 61.49554 & 64.49029 & 65.6519 & 65.66413 \\
\hline Spread (inch) & 6.875 & 8 & 9.5 & 10.375 \\
\hline
\end{tabular}

Mix: M50BA: $50 \%$ fly ash, $50 \%$ bottom ash

\begin{tabular}{|lc|r|r|r|r|}
\hline Container & 26 & 23 & 29 & 38 \\
\hline Mass c. & $(\mathrm{g})$ & 36.48 & 36.28 & 36.76 & 36.59 \\
\hline Mass full & $(\mathrm{g})$ & 160.94 & 142.82 & 141.71 & 174.15 \\
\hline Mass dry & $(\mathrm{g})$ & 121.68 & 107.93 & 107.37 & 128.78 \\
\hline W & 46.07981 & 48.69505 & 48.63334 & 49.21358 \\
\hline Spread (inch) & 6.75 & 8.375 & 9 & 10 \\
\hline
\end{tabular}

Mix: M75BA: $25 \%$ fly ash, $75 \%$ bottom ash

\begin{tabular}{|lc|r|r|r|r|}
\hline Container & 18 & 13 & 14 & 9 \\
\hline Mass c. & $(\mathrm{g})$ & 29.56 & 30.95 & 27.86 & 31.15 \\
\hline Mass full & $(\mathrm{g})$ & 137.96 & 137.95 & 155.8 & 139.29 \\
\hline Mass dry & $(\mathrm{g})$ & 110.81 & 109.39 & 122.32 & 110.89 \\
\hline W & 33.41538 & 36.40999 & 35.44357 & 35.61575 \\
\hline Spread (inch) & 4.875 & 8 & 8 & 9 \\
\hline
\end{tabular}

Mix: M90BA: $10 \%$ fly ash, $90 \%$ bottom ash

\begin{tabular}{|lc|r|r|r|r|}
\hline Container & 19 & 37 & 34 & 35 \\
\hline Mass c. & $(\mathrm{g})$ & 29.38 & 36.61 & 36.43 & 36.04 \\
\hline Mass full & $(\mathrm{g})$ & 162.41 & 197.13 & 222.05 & 206.13 \\
\hline Mass dry & $(\mathrm{g})$ & 127.99 & 155.6 & 172.63 & 160.83 \\
\hline W & 34.90518 & 34.90209 & 36.28488 & 36.30099 \\
\hline Spread (inch) & 5.625 & 6 & 9.375 & 9.625 \\
\hline
\end{tabular}


Mix: M2BA3C: $95 \%$ fly ash, $2 \%$ bottom ash, 3\% cement

\begin{tabular}{|lc|r|r|r|r|}
\hline Container & 14 & 5 & 18 & 7 \\
\hline Mass c. & $(\mathrm{g})$ & 29.56 & 33.21 & 29.96 & 31.24 \\
\hline mass full & $(\mathrm{g})$ & 105.71 & 115.58 & 101.93 & 116.04 \\
\hline mass dry & (g) & 73.79 & 80.35 & 70.45 & 78.94 \\
\hline W & 72.16821 & 74.73483 & 77.74759 & 77.77778 \\
\hline Spread (inch) & 5.75 & 7.75 & 9.5 & 10 \\
\hline
\end{tabular}

Mix: M7BA3C: $90 \%$ fly ash, $7 \%$ bottom ash, $3 \%$ cement

\begin{tabular}{|c|c|c|c|c|}
\hline Container & 29 & 30 & 33 & 31 \\
\hline Mass c. & & 36.48 & 36.81 & 36.79 \\
\hline Mass full (g) & & 144.35 & 120.78 & 157.29 \\
\hline Mass dry (g) & & 98.89 & 84.86 & 105.5 \\
\hline W & & 72.84089 & 74.75546 & 75.37476 \\
\hline Spread (inch) & & 8 & 9.5 & 9.75 \\
\hline
\end{tabular}

Mix: M22BA3C: $75 \%$ fly ash, $22 \%$ bottom ash, $3 \%$ cement

\begin{tabular}{|lc|r|r|r|r|}
\hline Container & 13 & 1 & 9 & 18 \\
\hline Mass c. & $(\mathrm{g})$ & 30.87 & 30.84 & 32.94 & 27.74 \\
\hline Mass full & $(\mathrm{g})$ & 112.11 & 121.12 & 133.27 & 128.39 \\
\hline Mass dry & $(\mathrm{g})$ & 80.98 & 86.36 & 93.7 & 88.11 \\
\hline W & & 62.12333 & 62.60807 & 65.12508 & 66.72188 \\
\hline Spread (inch) & 5.625 & 7.25 & 8.5 & 10.125 \\
\hline
\end{tabular}

Mix: M47BA3C: $50 \%$ fly ash, $47 \%$ bottom ash, $3 \%$ cement

\begin{tabular}{|lc|r|r|r|r|}
\hline Container & 23 & 26 & 38 & 24 \\
\hline Mass c. & $(\mathrm{g})$ & 36.22 & 36.6 & 36.63 & 36.68 \\
\hline Mass full & $(\mathrm{g})$ & 134.7 & 130.8 & 122.77 & 168.92 \\
\hline Mass dry & $(\mathrm{g})$ & 104.52 & 101.49 & 95.61 & 125.16 \\
\hline W & & 44.18741 & 45.16875 & 46.04951 & 49.4575 \\
\hline Spread (inch) & 4.5 & 6.75 & 7.75 & 9.25 \\
\hline
\end{tabular}

Mix: M72BA3C: $25 \%$ fly ash, $72 \%$ bottom ash, $3 \%$ cement

\begin{tabular}{|lc|r|r|r|r|}
\hline Container & 17 & 10 & 8 & 11 \\
\hline Mass c. & $(\mathrm{g})$ & 25.95 & 26.03 & 26 & 27.73 \\
\hline Mass full & $(\mathrm{g})$ & 126.02 & 131.08 & 134.32 & 144.88 \\
\hline Mass dry & $(\mathrm{g})$ & 100.66 & 104.43 & 105.83 & 113.55 \\
\hline W & & 33.94459 & 33.99235 & 35.68834 & 36.50664 \\
\hline Spread (inch) & 6 & 7.5 & 8.25 & 9.75 \\
\hline
\end{tabular}

Mix: M87BA3C: $10 \%$ fly ash, $87 \%$ bottom ash, $3 \%$ cement

\begin{tabular}{|lc|r|r|r|r|}
\hline Container & 18 & 5 & 9 & 2 \\
\hline Mass c. & $(\mathrm{g})$ & 29.46 & 32.25 & 30.67 & 30.47 \\
\hline Mass full & $(\mathrm{g})$ & 141.76 & 152.07 & 136.44 & 141.38 \\
\hline Mass dry & (g) & 113.03 & 121.22 & 108.04 & 111.8 \\
\hline W & & 34.37837 & 34.67461 & 36.70673 & 36.37034 \\
\hline Spread (inch) & 4.5 & 7.875 & 9.625 & 9.625 \\
\hline
\end{tabular}


Mix: M5RS: $95 \%$ fly ash, $5 \%$ river sand

\begin{tabular}{|lc|r|r|r|r|}
\hline Container & TPC & 21 & 7 & 29 \\
\hline Mass c. & $(\mathrm{g})$ & 29.33 & 35.97 & 28.5 & 36.72 \\
\hline Mass full & $(\mathrm{g})$ & 101.36 & 104.87 & 111.89 & 168.53 \\
\hline Mass dry & $(\mathrm{g})$ & 71.3 & 75.35 & 75.92 & 111.25 \\
\hline W & & 71.62259 & 74.96191 & 75.85407 & 76.85496 \\
\hline Spread (inch) & 5.625 & 8 & 9 & 9.375 \\
\hline
\end{tabular}

Mix: M10RS: $90 \%$ fly ash, $10 \%$ river sand

\begin{tabular}{|lc|r|r|r|r|}
\hline Container & 33 & 31 & 35 & 30 \\
\hline Mass c. & $(\mathrm{g})$ & 36.84 & 36.85 & 36.11 & 36.52 \\
\hline Mass full & $(\mathrm{g})$ & 116.83 & 117.19 & 118.63 & 156.17 \\
\hline Mass dry & $(\mathrm{g})$ & 84.2 & 83.37 & 83.6 & 105.17 \\
\hline W & & 68.8978 & 72.69991 & 73.7629 & 74.28988 \\
\hline Spread (inch) & 6.25 & 8.5 & 9.625 & 10.375 \\
\hline
\end{tabular}

Mix: M25RS: $75 \%$ fly ash, $25 \%$ river sand

\begin{tabular}{|c|c|c|c|c|}
\hline Container & 5 & 21 & 7 & 2 \\
\hline \begin{tabular}{|l|} 
Mass c. \\
\end{tabular} & 32.02 & 30.95 & 27.79 & 33.33 \\
\hline Mass full (g) & 110.73 & 112.37 & 122.06 & 122.99 \\
\hline Mass dry (g) & 82.93 & 83.13 & 87.34 & 89.28 \\
\hline W & 54.60617 & 56.0368 & 58.30395 & 60.25022 \\
\hline Spread (inch) & 5.5 & 7.125 & 8.625 & 9.75 \\
\hline
\end{tabular}

Mix: M50RS: $50 \%$ fly ash, $50 \%$ river sand

\begin{tabular}{|lc|r|r|r|r|}
\hline Container & 30 & 38 & 24 & 33 \\
\hline Mass c. & $(\mathrm{g})$ & 36.59 & 36.65 & 36.71 & 36.86 \\
\hline Mass full & $(\mathrm{g})$ & 167.56 & 156.35 & 162.12 & 182.77 \\
\hline Mass dry & (g) & 130.43 & 121.4 & 124.9 & 139.86 \\
\hline W & & 39.56735 & 41.23894 & 42.20433 & 41.66019 \\
\hline Spread (inch) & 6.875 & 8.375 & 9 & 10.25 \\
\hline
\end{tabular}

Mix: M75RS: $25 \%$ fly ash, $75 \%$ river sand

\begin{tabular}{|lc|r|r|r|r|}
\hline Container & 11 & 8 & 18 & 17 \\
\hline Mass c. & $(\mathrm{g})$ & 26 & 26.02 & 28.66 & 27.7 \\
\hline Mass full & $(\mathrm{g})$ & 121.89 & 150.74 & 156.05 & 150.03 \\
\hline Mass dry & (g) & 104.8 & 127.95 & 132.37 & 127.37 \\
\hline W & & 21.68782 & 22.35848 & 22.8329 & 22.73503 \\
\hline Spread (inch) & 5 & 6.625 & 8 & 9.75 \\
\hline
\end{tabular}

Mix: M90RS: $10 \%$ fly, $90 \%$ river sand

\begin{tabular}{|c|c|c|c|c|}
\hline Container & 10 & 3 & 9 & 13 \\
\hline Mass c. & 26.04 & 33.92 & 29.7 & \\
\hline Mass full $(\mathrm{g})$ & 126.91 & 163.47 & 112.65 & This mix \\
\hline Mass dry (g) & 108.23 & 139.75 & 96.44 & flow \\
\hline $\mathrm{W}$ & 22.72783 & 22.4133 & 24.28828 & \\
\hline Spread (inch) & 7 & 6.625 & 6.375 & \\
\hline \multicolumn{5}{|c|}{ Mix: M85RS: $15 \%$ fly ash, $85 \%$ river sand } \\
\hline Container & 30 & 34 & 38 & 33 \\
\hline Mass c. & 36.2 & 36.5 & 36.63 & 36.89 \\
\hline Mass full & 206.11 & 155.33 & 218.71 & 260.46 \\
\hline Mass dry (g) & 178.76 & 135.01 & 186.97 & 221.21 \\
\hline W & 19.1849 & 20.62735 & 21.11215 & 21.29449 \\
\hline Spread (inch) & 5.25 & 6.25 & 7.5 & 9.75 \\
\hline
\end{tabular}


Mix: M2RS3C: $95 \%$ fly ash, $2 \%$ river sand, $3 \%$ cement

\begin{tabular}{|lc|r|r|r|r|}
\hline Container & 26 & 34 & 23 & 31 \\
\hline Mass c. & $(\mathrm{g})$ & 36.57 & 36.5 & 36.38 & 36.84 \\
\hline Mass full & $(\mathrm{g})$ & 124.41 & 135.8 & 147.01 & 174.05 \\
\hline Mass dry & (g) & 88.6 & 94.22 & 99.86 & 114.3 \\
\hline W & 68.82568 & 72.03742 & 74.27536 & 77.13659 \\
\hline Spread (inch) & 4.875 & 7 & 8.375 & 10 \\
\hline
\end{tabular}

Mix: M7RS3C: $90 \%$ fly ash, $7 \%$ river sand, 3\% cement

\begin{tabular}{|lc|r|r|r|r|}
\hline Container & 7 & 19 & 14 & 18 \\
\hline Mass c. & $(\mathrm{g})$ & 31.25 & 32.22 & 30.46 & 28.68 \\
\hline Mass full & $(\mathrm{g})$ & 120.63 & 128.35 & 132.69 & 128.32 \\
\hline Mass dry & (g) & 85.68 & 89.49 & 90.26 & 86.4 \\
\hline W & 64.21091 & 67.85402 & 70.95318 & 72.62647 \\
\hline Spread (inch) & 5 & 6.125 & 8.375 & 9.25 \\
\hline
\end{tabular}

Mix: M22RS3C: $75 \%$ fly ash, $22 \%$ river sand, $3 \%$ cement

\begin{tabular}{|c|c|c|c|c|}
\hline Container & 1 & 5 & \multicolumn{2}{|c|}{$18 \mid$ tpc } \\
\hline Mass c. $\quad(\mathrm{g})$ & 30.84 & 30.69 & 26.77 & 28.84 \\
\hline Mass full & 133.19 & 143.51 & 137.33 & 132.16 \\
\hline Mass dry (g) & 96.3 & 101.99 & 96.1 & 92.02 \\
\hline W & 56.35503 & 58.23282 & 59.46921 & 63.53276 \\
\hline Spread (inch) & 4.875 & 7.25 & 8.375 & 10.125 \\
\hline
\end{tabular}

Mix: M47RS3C: $50 \%$ fly ash, $47 \%$ river sand, $3 \%$ cement

\begin{tabular}{|c|c|c|c|c|}
\hline Container & 9 & 21 & 10 & 8 \\
\hline Mass c. & 29.7 & 30.77 & 27.79 & 31.2 \\
\hline Mass full (g) & 123.91 & 115.48 & 131.58 & 137.21 \\
\hline Mass dry (g) & 97.87 & 91.26 & 100.9 & 105.04 \\
\hline $\mathrm{W}$ & 38.19862 & 40.03968 & 41.96416 & 43.56717 \\
\hline Spread & 4.5 & 6.25 & 8.5 & 9.75 \\
\hline
\end{tabular}

Mix: M72RS3C: $25 \%$ fly ash, $72 \%$ river sand, $3 \%$ cement

\begin{tabular}{|c|c|c|c|c|}
\hline Container & 24 & 33 & 38 & 30 \\
\hline Mass c. & 36.68 & 36.84 & 36.66 & 36.57 \\
\hline Mass full & 122.08 & 150.92 & 131.78 & 197.93 \\
\hline Mass dry (g) & 106.56 & 129.01 & 112.65 & 166.26 \\
\hline $\mathrm{W}$ & 22.2095 & 23.77129 & 25.17437 & 24.41977 \\
\hline Spread & 4.75 & 7.5 & 9 & 10 \\
\hline
\end{tabular}

Mix: M87RS3C: $10 \%$ fly ash, $87 \%$ river sand, $3 \%$ cement

\begin{tabular}{|lc|r|r|r|r|}
\hline Container & 5 & 7 & 2 & 11 \\
\hline Mass c. & $(\mathrm{g})$ & 28.38 & 31.49 & 27.89 & 26.83 \\
\hline Mass full & (g) & \multicolumn{4}{|l|}{} \\
\hline Mass dry & (g) & \multicolumn{4}{|l|}{ This mix does not produce adequate flow } \\
\hline W & & & & \\
\hline Spread (inch) & 8.75 & 8.625 & & \\
\hline
\end{tabular}


Mix: M5FS: 95\% fly ash, 5\% foundry sand

\begin{tabular}{|lc|r|r|r|r|}
\hline Container & 5 & 7 & 2 & 11 \\
\hline Mass c. & $(\mathrm{g})$ & 28.29 & 31.47 & 27.87 & 28.81 \\
\hline Mass full & $(\mathrm{g})$ & 95.67 & 120.57 & 109.79 & 122.22 \\
\hline Mass dry & $(\mathrm{g})$ & 68.75 & 83.66 & 74.87 & 82.16 \\
\hline W & 66.53485 & 70.72236 & 74.29787 & 75.08903 \\
\hline Spread (inch) & 4.75 & 6.625 & 9.5 & 10.25 \\
\hline
\end{tabular}

Mix: M10FS: $90 \%$ fly ash, $10 \%$ foundry sand

\begin{tabular}{|lc|r|r|r|r|}
\hline Container & 18 & 1 & 32 & 8 \\
\hline Mass c. & $(\mathrm{g})$ & 29.91 & 30.93 & 31.2 & 27.82 \\
\hline Mass full & $(\mathrm{g})$ & 108.91 & 123.81 & 132.42 & 137.52 \\
\hline Mass dry & $(\mathrm{g})$ & 78.41 & 86.17 & 91.19 & 92.11 \\
\hline W & & 62.8866 & 68.13903 & 68.72812 & 70.63307 \\
\hline Spread (inch) & 4.25 & 7.625 & 8.75 & 9.625 \\
\hline
\end{tabular}

Mix: M25FS: $75 \%$ fly ash, $25 \%$ foundry sand

\begin{tabular}{|c|c|c|c|c|}
\hline Container & 10 & 7 & 18 & 5 \\
\hline Mass c. & 28.81 & 31.18 & 29.17 & 30.71 \\
\hline Mass full (g) & 128.4 & 125.62 & 142.85 & 134.9 \\
\hline Mass dry (g) & 92.19 & 90.62 & 100.24 & 95.04 \\
\hline $\mathrm{W}$ & 57.13159 & 58.88291 & 59.95497 & 61.96176 \\
\hline Spread & 5.5 & 7 & 8.125 & 9.75 \\
\hline
\end{tabular}

Mix: M50FS: $50 \%$ fly ash, $50 \%$ foundry sand

\begin{tabular}{|lr|r|r|r|r|}
\hline Container & 19 & 14 & 9 & 21 \\
\hline Mass c. & $(\mathrm{g})$ & 31.02 & 29.69 & 27.96 & 30.85 \\
\hline Mass full & $(\mathrm{g})$ & 128.94 & 147.51 & 146.23 & 132.65 \\
\hline Mass dry & $(\mathrm{g})$ & 100.95 & 112.92 & 111.64 & 101.73 \\
\hline W & 40.02574 & 41.55953 & 41.33604 & 43.62302 \\
\hline Spread (inch) & 5 & 7 & 8.125 & 10 \\
\hline
\end{tabular}

Mix: M75FS: $25 \%$ fly ash, $75 \%$ foundry sand

\begin{tabular}{|lr|r|r|r|r|}
\hline Container & 26 & 23 & 24 & 31 \\
\hline Mass c. & $(\mathrm{g})$ & 36.57 & 36.32 & 36.66 & 36.9 \\
\hline Mass full & $(\mathrm{g})$ & 193.39 & 218.31 & 222.14 & 242.78 \\
\hline Mass dry & $(\mathrm{g})$ & 160.96 & 180.15 & 182.23 & 197.81 \\
\hline W & & 26.07123 & 26.53132 & 27.41636 & 27.9473 \\
\hline Spread (inch) & 4.25 & 7 & 8 & 9.375 \\
\hline
\end{tabular}

Mix: M90FS: $10 \%$ fly ash, $90 \%$ foundry sand

\begin{tabular}{|lr|r|r|r|r|}
\hline Container & 30 & 34 & 38 & 33 \\
\hline Mass c. & (g) & 36.53 & 36.48 & 36.62 & 36.88 \\
\hline Mass full & (g) & \multicolumn{4}{|l|}{} \\
\hline Mass dry & (g) & \multicolumn{3}{|l|}{ This mix does not produce adequate flow } \\
\hline W & & & & \\
\hline Spread (inch) & 5.125 & & & \\
\hline
\end{tabular}

Mix: M85FS: $15 \%$ fly ash, $85 \%$ foundry sand

\begin{tabular}{|lc|r|r|r|r|}
\hline Container & 14 & 18 & 17 & 9 \\
\hline Mass c. & $(\mathrm{g})$ & 29.36 & 26.04 & 25.93 & 33.69 \\
\hline Mass full & $(\mathrm{g})$ & 136.59 & 131.29 & 158.64 & 135.46 \\
\hline Mass dry & $(\mathrm{g})$ & 114.39 & 108.1 & 130.26 & 112.67 \\
\hline W & 26.10843 & 28.25981 & 27.20215 & 28.85541 \\
\hline Spread (inch) & 5 & 8.5 & 9.625 & 10.625 \\
\hline
\end{tabular}


Mix: M2FS3C: $95 \%$ fly ash, $2 \%$ foundry sand, $3 \%$ cement

\begin{tabular}{|c|c|c|c|c|}
\hline Container & 8 & 32 & 14 & 7 \\
\hline Mass c. & 28.89 & 27.78 & 31.96 & 28.86 \\
\hline Mass full & 121.09 & 125.5 & 131.6 & 127.43 \\
\hline Mass dry (g) & 82.95 & 84.32 & 89.15 & 84.73 \\
\hline $\mathrm{W}$ & 70.55124 & 72.83339 & 74.22626 & 76.42742 \\
\hline Spread (inch) & 6 & 7.75 & 9.625 & 11 \\
\hline
\end{tabular}

Mix: M7FS3C: $90 \%$ fly ash, $7 \%$ foundry sand, $3 \%$ cement

\begin{tabular}{|c|c|c|c|c|}
\hline Container & 7 & 1 & 5 & 21 \\
\hline Mass c. & 31.27 & 30.87 & 28.21 & 30.75 \\
\hline Mass full $(\mathrm{g})$ & 126.31 & 125.01 & 137.64 & 139.46 \\
\hline Mass dry (g) & 87.76 & 86.63 & 92.75 & 94.62 \\
\hline $\mathrm{W}$ & 68.24217 & 68.8307 & 69.55377 & 70.2051 \\
\hline Spread (inch) & 7 & 7.5 & 8.5 & 9.25 \\
\hline
\end{tabular}

Mix: M22FS3C: $75 \%$ fly ash, $22 \%$ foundry sand, 3\% cement

\begin{tabular}{|c|c|c|c|c|}
\hline Container & 5 & 18 & 9 & 11 \\
\hline Mass c. & 30.77 & 27.12 & 33.11 & 26.17 \\
\hline Mass full (g) & 141.26 & 120.12 & 147.75 & 130 \\
\hline Mass dry (g) & 100.31 & 85.1 & 103.57 & 89.09 \\
\hline $\mathrm{W}$ & 58.88697 & 60.40014 & 62.70224 & 65.01907 \\
\hline Spread & 6.25 & 7.25 & 8.875 & 10.875 \\
\hline
\end{tabular}

Mix: M47FS3C: $50 \%$ fly ash, $47 \%$ foundry sand, $3 \%$ cement

\begin{tabular}{|lc|r|r|r|r|}
\hline Container & 18 & 14 & 17 & 9 \\
\hline Mass c. & $(\mathrm{g})$ & 28.95 & 29.12 & 25.96 & 31.08 \\
\hline Mass full & $(\mathrm{g})$ & 143.78 & 145.91 & 139.71 & 136.39 \\
\hline Mass dry & $(\mathrm{g})$ & 110.02 & 110.85 & 105.34 & 103.26 \\
\hline W & & 41.64302 & 42.89734 & 43.29806 & 45.89914 \\
\hline Spread (inch) & 7 & 8.375 & 9 & 12 \\
\hline
\end{tabular}

Mix: M72FS3C: $25 \%$ fly ash, $72 \%$ foundry sand, $3 \%$ cement

\begin{tabular}{|c|c|c|c|}
\hline Container & 14 & 18 & 10 \\
\hline Mass c. & 30.84 & 28.42 & 31.55 \\
\hline Mass full & 119.5 & 130.89 & 149.33 \\
\hline Mass dry (g) & 101.12 & 108.67 & 123.15 \\
\hline $\mathrm{W}$ & 26.15253 & 27.68847 & 28.58079 \\
\hline Spread (inch) & 6.25 & 8.375 & 10.2 \\
\hline
\end{tabular}

Mix: M87FS3C: $10 \%$ fly ash, $87 \%$ foundry sand, $3 \%$ cement

\begin{tabular}{|c|c|c|c|}
\hline Container & 4 & 29 & 35 \\
\hline Mass c. $\quad(\mathrm{g})$ & 36.72 & 36.81 & 36.03 \\
\hline Mass full & 198.57 & 223.77 & 233.06 \\
\hline Mass dry (g) & 166.11 & 185.58 & 192.48 \\
\hline W & 25.08695 & 25.6705 & 25.938 \\
\hline Spread (inch) & 8.25 & 8.625 & 10.2 \\
\hline
\end{tabular}




\section{Appendix B \\ Data Collected From Strength Testing}




\section{Bottom ash 7 day strength}

Mix: M90BA 7 day

\begin{tabular}{|c|c|c|c|c|}
\hline Height (in) & 5.701 & Height & 5.538 & AVG. \\
\hline Diameter (in) & 3.018 & Diameter (in) & 3.015 & \\
\hline Area $\quad\left(\right.$ in $\left.^{2}\right)$ & 7.1536 & Area $\quad\left(\mathrm{in}^{2}\right)$ & 7.1394 & \\
\hline oad number & 184 & Load number $(\mathrm{lb} / \mathrm{t}$ & 153 & \\
\hline Compressive stre & 70.733 & Compressive strength (psi) & 58.933 & 64.833 \\
\hline
\end{tabular}

Mix: M83BA 7 day

\begin{tabular}{|c|c|c|c|}
\hline Height (in) & 5.635 & Height $\quad$ (in) & 5.561|AVG. \\
\hline Diameter (in) & 3.016 & Diameter (in) & 3.023 \\
\hline Area $\quad\left(\mathrm{in}^{2}\right)$ & 7.1441 & Area $\quad\left(\mathrm{in}^{2}\right)$ & 7.1773 \\
\hline Load number (Ib/2.75) & 348 & Load number (Ib/2.75) & 250 \\
\hline Compressive strength ( & 133.95 & Compressive strength (psi) & 95.786 \\
\hline
\end{tabular}

Mix: M75BA 7 day

\begin{tabular}{|c|c|c|c|}
\hline Height & 5.645 & Height & 5.785|AVG. \\
\hline Diameter (in) & 3.015 & Diameter (in) & 3.031 \\
\hline Area $\quad\left(\mathrm{in}^{2}\right)$ & 7.1394 & \begin{tabular}{|ll} 
Area & $\left(\mathrm{in}^{2}\right)$
\end{tabular} & 7.2154 \\
\hline Load number (Ib/2.75) & 454 & Load number (Ib/2.75) & 516 \\
\hline Compressive strength ( $\mathrm{k}$ & 174.87 & Compressive strength (psi) & 196.66 \\
\hline
\end{tabular}

Mix: M50BA 7 day

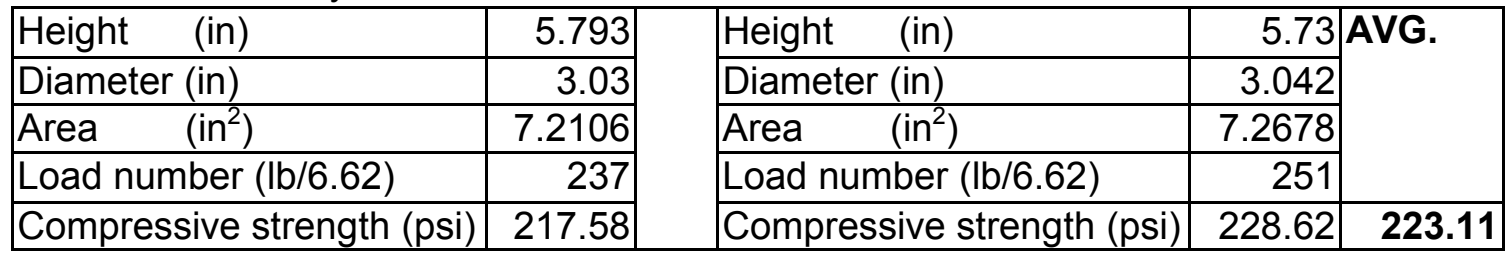

Mix: M25BA 7 day

\begin{tabular}{|c|c|c|c|c|}
\hline Height (in) & 5.641 & Height & 5.688 & AVG. \\
\hline Diameter (in) & 3.031 & Diameter (in) & 3.025 & \\
\hline Area $\quad\left(\mathrm{in}^{2}\right)$ & 7.2154 & Area $\quad\left(\mathrm{in}^{2}\right)$ & 7.1868 & \\
\hline oad number (lk & 319 & Load number (It & 275 & \\
\hline Compressive strength (psi) & 292.67 & Compressive strength (psi) & 253.30 & 272.99 \\
\hline
\end{tabular}

Mix: M10BA 7 day

\begin{tabular}{|c|c|c|c|c|}
\hline Height & 5.672 & Height & 5.628 & AVG. \\
\hline Diameter (in) & 3.022 & Diameter (in) & 3.029 & \\
\hline Area $\quad\left(\mathrm{in}^{2}\right)$ & 7.1726 & Area $\quad\left(\mathrm{in}^{2}\right)$ & 7.2059 & \\
\hline -oad number (Ib & 275 & Load number (Ib & 208 & \\
\hline Compressive strength (psi) & 253.81 & Compressive strength (psi) & 191.08 & 222.45 \\
\hline
\end{tabular}




\section{Bottom Ash 14 day Strength}

Mix: M90BA 14 day

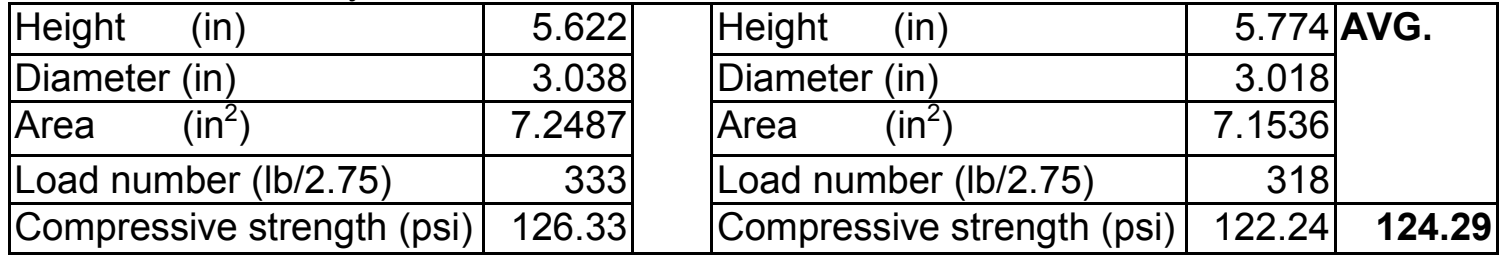

Mix: M83BA 14 day

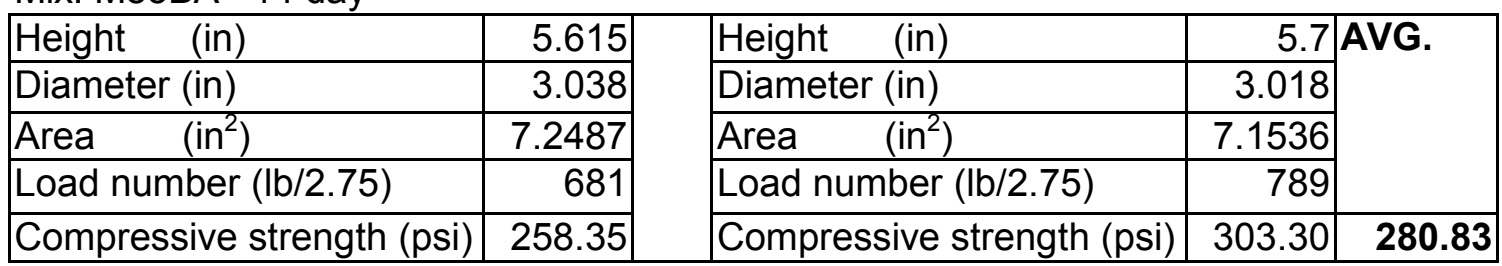

Mix: M75BA 14 day

\begin{tabular}{|c|c|c|c|}
\hline Height (in) & 5.738 & Height (in) & 5.635 AVG. \\
\hline Diameter (in) & 3.041 & Diameter (in) & 3.033 \\
\hline Area $\quad\left(\mathrm{in}^{2}\right)$ & 7.2631 & Area $\quad\left(\mathrm{in}^{2}\right)$ & 7.2249 \\
\hline Load number (lb/3) & 1030 & Load number $(\mathrm{lb} / 3)$ & 1124 \\
\hline Compressive strength (psi) & 389.98 & Compressive strength (psi) & 427.82 \\
\hline
\end{tabular}

Mix: M50BA 14 day

\begin{tabular}{|c|c|c|c|}
\hline Teight & 5.73 & Height & 5.703|AVG. \\
\hline Diameter (in) & 3.033 & Diameter (in) & 3.028 \\
\hline Area $\quad\left(\mathrm{in}^{2}\right)$ & 7.2249 & Area $\quad\left(\right.$ in $\left.^{2}\right)$ & 7.2011 \\
\hline Load number (Ib/6.62) & 711 & Load number (Ib/6.62) & 675 \\
\hline Compressive strength (psi) & 651.46 & Compressive strength (psi) & 620.52 \\
\hline
\end{tabular}

Mix: M25BA 14 day

\begin{tabular}{|c|c|c|c|c|}
\hline leight & 5.72 & Height & 5.69 & AVG. \\
\hline Diameter (in) & 3.02 & Diameter (in) & 3.038 & \\
\hline Area $\quad\left(\right.$ in $\left.^{2}\right)$ & 7.1631 & \begin{tabular}{|ll} 
Area & $\left(\mathrm{in}^{2}\right)$ \\
\end{tabular} & 7.2487 & \\
\hline Load number (Ib/6.62) & 373 & Load number (Ib/6.62) & 459 & \\
\hline Compressive strength (psi) & 344.71 & Compressive strength (psi) & 419.18 & 381.95 \\
\hline
\end{tabular}

sample: M10BA 14 day

\begin{tabular}{|c|c|c|c|c|}
\hline Height & 5.612 & Height & 5.602 & AVG. \\
\hline Diameter (in) & 3.02 & Diameter (in) & 3.012 & \\
\hline Area $\quad\left(\mathrm{in}^{2}\right)$ & 7.163 & \begin{tabular}{|ll} 
Area & $\left(\mathrm{in}^{2}\right)$ \\
\end{tabular} & 7.1252 & \\
\hline Load number (lb/6.62) & 257 & Load number (Ib/6.62) & 401 & \\
\hline Compressive strength (psi) & 37.513 & Compressive strength (psi) & 372.56 & 305.0 \\
\hline
\end{tabular}


Bottom Ash 28 day Strength

Mix: M90BA 28 day

\begin{tabular}{|c|c|c|c|c|}
\hline \multirow{2}{*}{\begin{tabular}{|l|l|} 
Height (in) \\
Diameter (in) \\
\end{tabular}} & 5.678 & Height & 5.776 & \multirow{3}{*}{ AVG. } \\
\hline & 3.015 & Diameter (in) & 3.025 & \\
\hline Area $\quad\left(\mathrm{in}^{2}\right)$ & 7.1394 & Area $\quad\left(\mathrm{in}^{2}\right)$ & 7.1868 & \\
\hline Load number (lb/6.62) & 330 & Load number (Ib/6.62) & 382 & \\
\hline Compressive strength (psi) & 305.99 & Compressive strength (psi) & 351.86 & 328.93 \\
\hline
\end{tabular}

Mix: M83BA 28 day

\begin{tabular}{|c|c|c|c|c|}
\hline \multirow{2}{*}{$\begin{array}{l}\text { Height (in) } \\
\text { Diameter (in) }\end{array}$} & 5.72 & Height & 5.629 & \multirow{4}{*}{ AVG. } \\
\hline & 3.031 & Diameter (in) & 3.042 & \\
\hline Area $\quad\left(\mathrm{in}^{2}\right)$ & 7.2154 & Area $\quad\left(\mathrm{in}^{2}\right)$ & 7.2678 & \\
\hline Load number (Ib/6.62) & 729 & Load number (Ib/6.62) & 515 & \\
\hline Compressive strength (psi) & 668.84 & Compressive strength (psi) & 469.09 & 568.97 \\
\hline
\end{tabular}

Mix: M75BA 28 day

\begin{tabular}{|c|c|c|c|c|}
\hline \multirow{2}{*}{$\begin{array}{l}\text { Height (in) } \\
\text { Diameter (in) }\end{array}$} & 5.622 & Height & 5.671 & \multirow{3}{*}{ AVG. } \\
\hline & 3.02 & Diameter (in) & 3.023 & \\
\hline Area $\quad\left(\mathrm{in}^{2}\right)$ & 7.1631 & Area $\quad\left(\mathrm{in}^{2}\right)$ & 7.1773 & \\
\hline Load number (Ib/6.62) & 997 & Load number (Ib/6.62) & 895 & \\
\hline Compressive strength (psi) & 921.40 & Compressive strength (psi) & 825.49 & 873.45 \\
\hline
\end{tabular}

Mix: M50BA 28 day

\begin{tabular}{|c|c|c|c|c|}
\hline Height & 5.721 & Height & 5.742 & AVG. \\
\hline Diameter (in) & 3.034 & Diameter (in) & 3.034 & \\
\hline Area $\quad\left(\mathrm{in}^{2}\right)$ & 7.2297 & Area $\quad\left(\mathrm{in}^{2}\right)$ & 7.2297 & \\
\hline Load number (Ib/6.62) & 624 & Load number (lb/6.62) & 535 & \\
\hline Compressive strength (psi) & 571.37 & Compressive strength (psi) & 489.88 & 530.6 \\
\hline
\end{tabular}

Mix: M25BA 28 day

\begin{tabular}{|c|c|c|c|c|}
\hline Height $\quad$ (in) & 5.681 & Height (in) & 5.701 & AVG. \\
\hline Diameter (in) & 3.033 & Diameter (in) & 3.032 & \\
\hline Area $\quad\left(\mathrm{in}^{2}\right)$ & 7.2249 & Area $\quad\left(\mathrm{in}^{2}\right)$ & 7.2201 & \\
\hline Load number (Ib/6.62) & 426 & Load number (Ib/6.62) & 412 & \\
\hline Compressive strength (psi) & 390.33 & Compressive strength (psi) & 377.75 & 384.04 \\
\hline
\end{tabular}

Mix: M10BA 28 day

\begin{tabular}{|c|c|c|c|c|}
\hline \multirow{2}{*}{$\begin{array}{l}\text { Height (in) } \\
\text { Diameter (in) }\end{array}$} & 5.675 & Height & 5.5 & \multirow{4}{*}{ AVG. } \\
\hline & 3.025 & Diameter (in) & 3.02 & \\
\hline Area $\quad\left(\mathrm{in}^{2}\right)$ & 7.1868 & Area $\quad\left(\mathrm{in}^{2}\right)$ & 7.1631 & \\
\hline Load number (Ib/6.62) & 264 & Load number (Ib/6.62) & 291 & \\
\hline Compressive strength (psi) & 243.17 & Compressive strength (psi) & 268.93 & 256.06 \\
\hline
\end{tabular}


$\underline{\text { River sand } 7 \text { day Strength }}$

Mix: M85RS 7 day

\begin{tabular}{|c|c|c|c|c|}
\hline Height & 5.724 & Height & 5.723 & AVG. \\
\hline Diameter (in) & 3.005 & Diameter (in) & 3.006 & \\
\hline Area $\quad\left(\mathrm{in}^{2}\right)$ & 7.0921 & Area $\quad\left(\mathrm{in}^{2}\right)$ & 7.0968 & \\
\hline Load number (Ib/2.75) & 293 & Load number (lb/2.75) & 236 & \\
\hline Compressive strength (psi) & 113.61 & Compressive strength (psi) & 91.448 & 102.53 \\
\hline
\end{tabular}

Mix: M80RS 7 day

\begin{tabular}{|c|c|c|c|c|}
\hline Height & 5.772 & Height & 5.728 & AVG. \\
\hline Diameter (in) & 3.012 & Diameter (in) & 3.019 & \\
\hline Area $\quad\left(\mathrm{in}^{2}\right)$ & 7.1252 & Area $\quad\left(\mathrm{in}^{2}\right)$ & 7.1584 & \\
\hline Load number (Ib/2.75) & 440 & Load number (Ib/2.75) & 468 & \\
\hline Compressive strength (psi) & 169.81 & Compressive strength (psi) & 179.78 & 174 \\
\hline
\end{tabular}

Mix: M75RS 7 day

\begin{tabular}{|c|c|c|c|c|}
\hline Height & 5.714 & Height & 5.64 & AVG. \\
\hline Diameter (in) & 3.022 & Diameter (in) & 3.025 & \\
\hline Area $\quad\left(\mathrm{in}^{2}\right)$ & 7.1726 & Area $\quad\left(\right.$ in $\left.^{2}\right)$ & 7.1868 & \\
\hline Load number (Ib/2.75) & 757 & Load number (Ib/2.75) & 740 & \\
\hline Compressive strength (psi) & 290.235 & Compressive strength (psi) & 283.15 & 286.69 \\
\hline
\end{tabular}

Mix: M50RS 7 day

\begin{tabular}{|c|c|c|c|c|}
\hline Height $\quad$ (in) & 5.651 & Height & 5.583 & AVG. \\
\hline Diameter (in) & 3.034 & Diameter (in) & 3.028 & \\
\hline Area $\quad\left(\mathrm{in}^{2}\right)$ & 7.2297 & Area $\quad\left(\mathrm{in}^{2}\right)$ & 7.2011 & \\
\hline Load number (Ib/6.62) & 214 & Load number (Ib/6.62) & 179 & \\
\hline Compressive strength (psi) & 195.95 & Compressive strength (psi) & 164.55 & 180.25 \\
\hline
\end{tabular}

Mix: M25RS 7 day

\begin{tabular}{|c|c|c|c|c|}
\hline Height & 5.689 & Height & 5.695 & AVG. \\
\hline Diameter (in) & 3.032 & Diameter (in) & 3.028 & \\
\hline Area $\quad\left(\mathrm{in}^{2}\right)$ & 7.2201 & Area $\quad\left(\mathrm{in}^{2}\right)$ & 7.2011 & \\
\hline Load number (lb/6.62) & 240 & Load number (Ib/6.62) & 205 & \\
\hline Compressive strength (psi) & 220.04 & Compressive strength (psi) & 188.45 & 204.25 \\
\hline
\end{tabular}

Mix: M10RS 7 day

\begin{tabular}{|c|c|c|c|c|}
\hline Height & 5.63 & Height & 5.668 & AVG. \\
\hline Diameter (in) & 3.029 & Diameter (in) & 3.023 & \\
\hline Area $\quad\left(\mathrm{in}^{2}\right)$ & 7.2059 & Area $\quad\left(\right.$ in $\left.^{2}\right)$ & 7.1773 & \\
\hline Load number (Ib/6.62) & 183 & Load number (Ib/6.62) & 191 & \\
\hline Compressive strength (psi) & 168.12 & Compressive strength (psi) & 176.16 & 172.14 \\
\hline
\end{tabular}




\section{$\underline{\text { River Sand } 14 \text { day Strength }}$}

Mix: M85RS 14 day

\begin{tabular}{|c|c|c|c|c|}
\hline Height & 5.692 & Height & 5.585 & AVG. \\
\hline Diameter (in) & 3.011 & Diameter (in) & 3.02 & \\
\hline Area $\quad\left(\mathrm{in}^{2}\right)$ & 7.1205 & Area $\quad\left(\mathrm{in}^{2}\right)$ & 7.1631 & \\
\hline Load number (Ib/2.75) & 230 & Load number (Ib/2.75) & 231 & \\
\hline Compressive strength (psi) & 88.827 & Compressive strength (psi) & 88.611 & 88.755 \\
\hline
\end{tabular}

Mix: M80RS 14 day

\begin{tabular}{|c|c|c|c|c|}
\hline Height (in) & 5.755 & Height & 5.744 & AVG. \\
\hline Diameter (in) & 3.02 & Diameter (in) & 3.009 & \\
\hline Area $\quad\left(\mathrm{in}^{2}\right)$ & 7.1631 & Area $\quad\left(\mathrm{in}^{2}\right)$ & 7.1110 & \\
\hline Load number (Ib/2.75) & 547 & Load number (Ib/2.75) & 441 & \\
\hline Compressive strength (psi) & 209.99 & Compressive strength (psi) & 170.54 & 190.27 \\
\hline
\end{tabular}

Mix: M75RS 14 day

\begin{tabular}{|c|c|c|c|c|}
\hline Height (in) & 5.78 & Height (in) & 5.72 & AVG. \\
\hline Diameter (in) & 3.012 & Diameter (in) & 3.017 & \\
\hline Area $\quad\left(\mathrm{in}^{2}\right)$ & 7.1252 & Area $\quad\left(\mathrm{in}^{2}\right)$ & 7.1489 & \\
\hline Load number (Ib/2.75) & 479 & Load number (lb/2.75) & 609 & \\
\hline Compressive strength (psi) & 184.87 & Compressive strength (psi) & 234.26 & 209.57 \\
\hline
\end{tabular}

Mix: M50RS 14 day

\begin{tabular}{|c|c|c|c|c|}
\hline Height & 5.778 & Height & 5.637 & AVG. \\
\hline Diameter (in) & 3.036 & Diameter (in) & 3.027 & \\
\hline Area $\quad\left(\mathrm{in}^{2}\right)$ & 7.2392 & Area $\quad\left(\mathrm{in}^{2}\right)$ & 7.1963 & \\
\hline Load number (Ib/6.62) & 268 & Load number (Ib/6.62) & 263 & \\
\hline Compressive strength (psi) & 245.07 & Compressive strength (psi) & 241.93 & 243.51 \\
\hline
\end{tabular}

Mix: M25RS 14 day

\begin{tabular}{|c|c|c|c|c|}
\hline Height & 5.773 & Height & 5.715 & AVG. \\
\hline Diameter (in) & 3.016 & Diameter (in) & 3.023 & \\
\hline Area $\quad\left(\mathrm{in}^{2}\right)$ & 7.1441 & Area $\quad\left(\mathrm{in}^{2}\right)$ & 7.1773 & \\
\hline Load number (Ib/6.62) & 260 & Load number (lb/6.62) & 206 & \\
\hline Compressive strength (psi) & 240.92 & Compressive strength (psi) & 190.00 & 215.46 \\
\hline
\end{tabular}

Mix: M10RS 14 day

\begin{tabular}{|c|c|c|c|c|}
\hline Height $\quad$ (in) & 5.723 & Height & 5.771 & AVG. \\
\hline Diameter (in) & 3.01 & Diameter (in) & 3.014 & \\
\hline Area $\quad\left(\mathrm{in}^{2}\right)$ & 7.1157 & Area $\quad\left(\mathrm{in}^{2}\right)$ & 7.1347 & \\
\hline Load number (lb/6.62) & 186 & Load number (Ib/6.62) & 234 & \\
\hline Compressive strength (psi) & 173.04 & Compressive strength (psi) & 217.11 & 195.08 \\
\hline
\end{tabular}


River Sand 28 day Strength

Mix: M85RS 28 day

\begin{tabular}{|c|c|c|c|c|}
\hline Height & 5.603 & Height & 5.669 & AVG. \\
\hline Diameter (in) & 3.007 & Diameter (in) & 3.019 & \\
\hline Area $\quad\left(\mathrm{in}^{2}\right)$ & 7.1016 & Area $\quad\left(\mathrm{in}^{2}\right)$ & 7.1584 & \\
\hline Load number (lb/6.62) & 95 & Load number (Ib/6.62) & 115 & \\
\hline Compressive strength (psi) & 88.557 & Compressive strength (psi) & 106.35 & 97.454 \\
\hline
\end{tabular}

Mix: M80RS 28 day

\begin{tabular}{|c|c|c|c|c|}
\hline \multirow{2}{*}{$\begin{array}{l}\text { Height (in) } \\
\text { Diameter (in) }\end{array}$} & 5.695 & Height & 5.731 & \multirow{4}{*}{ AVG. } \\
\hline & 3.01 & Diameter (in) & 3.015 & \\
\hline Area $\quad\left(\mathrm{in}^{2}\right)$ & 7.1157 & Area $\quad\left(\mathrm{in}^{2}\right)$ & 7.1394 & \\
\hline Load number (Ib/6.62) & 176 & Load number (Ib/6.62) & 185 & \\
\hline Compressive strength (psi) & 163.73 & Compressive strength (psi) & 171.53 & 167.64 \\
\hline
\end{tabular}

Mix: M75RS 28 day

\begin{tabular}{|c|c|c|c|c|}
\hline \multirow{2}{*}{$\frac{\text { Height (in) }}{\text { Diameter (in) }}$} & 5.723 & Height & 5.777 & \multirow[t]{3}{*}{ AVG. } \\
\hline & 3.018 & Diameter (in) & 3.022 & \\
\hline Area $\quad\left(\mathrm{in}^{2}\right)$ & 7.1536 & Area $\quad\left(\mathrm{in}^{2}\right)$ & 7.1726 & \\
\hline Load number (Ib/6.62) & 248 & Load number (Ib/6.62) & 314 & \\
\hline Compressive strength (psi) & 229.49 & Compressive strength (psi) & 289.8 & 259.65 \\
\hline
\end{tabular}

Mix: M50RS 28 day

\begin{tabular}{|c|c|c|c|c|}
\hline Height (in) & 5.737 & Height (in) & 5.745 & AVG. \\
\hline Diameter (in) & 3.026 & Diameter (in) & 3.019 & \\
\hline Area $\quad\left(\mathrm{in}^{2}\right)$ & 7.1916 & Area $\quad\left(\right.$ in $\left.^{2}\right)$ & 7.1584 & \\
\hline Load number (Ib/6.62) & 247 & Load number (lb/6.62) & 202 & \\
\hline Compressive strength (psi) & 227.36 & Compressive strength (psi) & 186.80 & 207.09 \\
\hline
\end{tabular}

Mix: M25RS 28 day

\begin{tabular}{|c|c|c|c|c|}
\hline Height & 5.706 & Height & 5.704 & AVG. \\
\hline Diameter (in) & 3.029 & Diameter (in) & 3.019 & \\
\hline Area $\quad\left(\mathrm{in}^{2}\right)$ & 7.2059 & Area $\quad\left(\right.$ in $\left.^{2}\right)$ & 7.1584 & \\
\hline Load number (Ib/6.62) & 346 & Load number (lb/6.62) & 227 & \\
\hline Compressive strength (psi) & 317.86 & Compressive strength (psi) & 209.92 & 263.9 \\
\hline
\end{tabular}

Mix: M10RS 28 day

\begin{tabular}{|c|c|c|c|c|}
\hline \multirow{2}{*}{$\begin{array}{l}\text { Height (in) } \\
\text { Diameter (in) } \\
\end{array}$} & 5.707 & Height & 5.766 & \multirow{4}{*}{$\begin{array}{ll}\text { AVG. } \\
\end{array}$} \\
\hline & 3.022 & Diameter (in) & 3.031 & \\
\hline Area $\quad\left(\mathrm{in}^{2}\right)$ & 7.1726 & Area $\quad\left(\mathrm{in}^{2}\right)$ & 7.2154 & \\
\hline Load number (Ib/6.62) & 236 & Load number (Ib/6.62) & 262 & \\
\hline Compressive strength (psi) & 217.81 & Compressive strength (psi) & 240.37 & 229.1 \\
\hline
\end{tabular}


Foundry Sand 7 Day Strength

Mix: M85FS 7 day

\begin{tabular}{|c|c|c|c|c|}
\hline Height (in) & 5.424 & Height (in) & 5.525 & AVG. \\
\hline Diameter (in) & 3.004 & Diameter (in) & 3.009 & \\
\hline Area $\quad\left(\mathrm{in}^{2}\right)$ & 7.0874 & Area $\quad\left(\mathrm{in}^{2}\right)$ & 7.1110 & \\
\hline Load number (Ib/2.75) & 185 & Load number (Ib/2.75) & 182 & \\
\hline Compressive strength (psi) & 71.781 & Compressive strength (psi) & 70.383 & 71.083 \\
\hline
\end{tabular}

Mix: M80FS 7 day

\begin{tabular}{|c|c|c|c|c|}
\hline \multirow{2}{*}{\begin{tabular}{|l|} 
Height (in) \\
Diameter (in) \\
\end{tabular}} & 5.655 & Height & 5.633 & \multirow{3}{*}{ AVG. } \\
\hline & 3.024 & Diameter (in) & 3.016 & \\
\hline Area $\quad\left(\mathrm{in}^{2}\right)$ & 7.1821 & Area $\quad\left(\right.$ in $\left.^{2}\right)$ & 7.1441 & \\
\hline Load number (Ib/2.75) & 265 & Load number (lb/2.75) & 303 & \\
\hline Compressive strength (psi) & 101.46 & Compressive strength (psi) & 116.63 & 109.05 \\
\hline
\end{tabular}

Mix: M75FS 7 day

\begin{tabular}{|c|c|c|c|c|}
\hline Height & 5.686 & Height & 5.709 & AVG. \\
\hline Diameter (in) & 3.016 & Diameter (in) & 3.023 & \\
\hline Area $\quad\left(\mathrm{in}^{2}\right)$ & 7.1441 & Area $\quad\left(\mathrm{in}^{2}\right)$ & 7.1773 & \\
\hline Load number (Ib/2.75) & 358 & Load number (lb/2.75) & 386 & \\
\hline Compressive strength (psi) & 137.80 & Compressive strength (psi) & 147.89 & 142.85 \\
\hline
\end{tabular}

Mix: M50FS 7 day

\begin{tabular}{|c|c|c|c|c|}
\hline Height & 5.844 & Height (in) & 5.655 & AVG. \\
\hline Diameter (in) & 3.032 & Diameter (in) & 3.033 & \\
\hline Area $\quad\left(\right.$ in $\left.^{2}\right)$ & 7.2201 & Area $\quad\left(\mathrm{in}^{2}\right)$ & 7.2249 & \\
\hline Load number (Ib/6.62) & 189 & Load number (Ib/6.62) & 195 & \\
\hline Compressive strength (psi) & 173.28 & Compressive strength (psi) & 178.67 & 175.98 \\
\hline
\end{tabular}

Mix: M25FS 7 day

\begin{tabular}{|c|c|c|c|c|}
\hline Height (in) & 5.715 & Height & 5.849 & AVG. \\
\hline Diameter (in) & 3.03 & Diameter (in) & 3.029 & \\
\hline Area $\quad\left(\mathrm{in}^{2}\right)$ & 7.2106 & Area $\quad\left(\mathrm{in}^{2}\right)$ & 7.2059 & \\
\hline Load number (lb/6.62) & 200 & Load number (Ib/6.62) & 179 & \\
\hline Compressive strength (psi) & 183.617 & Compressive strength (psi) & 164.44 & 174.03 \\
\hline
\end{tabular}

Mix: M10FS 7 day

\begin{tabular}{|c|c|c|c|c|}
\hline \multirow{2}{*}{\begin{tabular}{|l|} 
Height $\quad$ (in) \\
Diameter (in)
\end{tabular}} & 5.741 & Height & 5.64 & \multirow{4}{*}{ AVG. } \\
\hline & 3.031 & Diameter (in) & 3.029 & \\
\hline Area $\quad\left(\mathrm{in}^{2}\right)$ & 7.2154 & Area $\quad\left(\mathrm{in}^{2}\right)$ & 7.2059 & \\
\hline Load number (Ib/6.62) & 186 & Load number (Ib/6.62) & 170 & \\
\hline Compressive strength (psi) & 170.65 & Compressive strength (psi) & 156.17 & 163.41 \\
\hline
\end{tabular}




\section{Foundry Sand 14 day Strength}

Mix: M85FS 14 day

\begin{tabular}{|c|c|c|c|c|}
\hline Height & 5.522 & Height & 5.255 & AVG. \\
\hline Diameter (in) & 3.015 & Diameter (in) & 2.999 & \\
\hline Area $\quad\left(\mathrm{in}^{2}\right)$ & 7.1394 & Area $\quad\left(\mathrm{in}^{2}\right)$ & 7.0638 & \\
\hline Load number (Ib/2.75) & 200 & Load number (Ib/2.75) & 216 & \\
\hline Compressive strength (psi) & 77.036 & Compressive strength (psi) & 84.089 & 80.563 \\
\hline
\end{tabular}

Mix: M80FS 14 day

\begin{tabular}{|c|c|c|c|c|}
\hline Height (in) & 5.566 & Height & 5.6 & \multirow{4}{*}{\begin{tabular}{|l|l} 
AVG. \\
3 \\
3 \\
3
\end{tabular}} \\
\hline Diameter (in) & 3.016 & Diameter (in) & 3.008 & \\
\hline Area $\quad\left(\mathrm{in}^{2}\right)$ & 7.1441 & Area $\quad\left(\mathrm{in}^{2}\right)$ & 7.1063 & \\
\hline Load number (Ib/2.75) & 374 & Load number (Ib/2.75) & 450 & \\
\hline Compressive strength (psi) & 143.96 & Compressive strength (psi) & 174.14 & 159.05 \\
\hline
\end{tabular}

Mix: M75FS 14 day

\begin{tabular}{|c|c|c|c|c|}
\hline Height (in) & 5.6 & Height (in) & 5.689 & AVG. \\
\hline Diameter (in) & 3.026 & Diameter (in) & 3.01 & \\
\hline Area $\quad\left(\mathrm{in}^{2}\right)$ & 7.1916 & Area $\quad\left(\mathrm{in}^{2}\right)$ & 7.1157 & \\
\hline Load number (Ib/2.75) & 394 & Load number (Ib/2.75) & 453 & \\
\hline Compressive strength (psi) & 150.66 & Compressive strength (psi) & 175.06 & 162.86 \\
\hline
\end{tabular}

Mix: M50FS 14 day

\begin{tabular}{|c|c|c|c|c|}
\hline Height & 5.691 & Height & 5.747 & AVG. \\
\hline Diameter (in) & 3.018 & Diameter (in) & 3.021 & \\
\hline Area $\quad\left(\mathrm{in}^{2}\right)$ & 7.1536 & Area $\quad\left(\mathrm{in}^{2}\right)$ & 7.1678 & \\
\hline Load number (Ib/2.75) & 623 & Load number (Ib/2.75) & 444 & \\
\hline Compressive strength (psi) & 239.49 & Compressive strength (psi) & 170.34 & 204.92 \\
\hline
\end{tabular}

Mix: M25FS 14 day

\begin{tabular}{|c|c|c|c|c|}
\hline \multirow{2}{*}{$\begin{array}{l}\text { Height (in) } \\
\text { Diameter (in) }\end{array}$} & 5.531 & Height & 5.544 & \multirow{4}{*}{ AVG. } \\
\hline & 3.033 & Diameter (in) & 3.03 & \\
\hline Area $\quad\left(\mathrm{in}^{2}\right)$ & 7.2249 & Area $\quad\left(\mathrm{in}^{2}\right)$ & 7.2106 & \\
\hline Load number (Ib/6.62) & 203 & Load number (Ib/6.62) & 250 & \\
\hline Compressive strength (psi) & 186.00 & Compressive strength (psi) & 229.52 & 207.76 \\
\hline
\end{tabular}

Mix: M10FS 14 day

\begin{tabular}{|c|c|c|c|c|}
\hline Height & 5.748 & Height & 5.758 & AVG. \\
\hline Diameter (in) & 3.036 & Diameter (in) & 3.028 & \\
\hline Area $\quad\left(\mathrm{in}^{2}\right)$ & 7.2392 & Area $\quad\left(\mathrm{in}^{2}\right)$ & 7.2011 & \\
\hline Load number (Ib/2.75) & 576 & Load number (Ib/2.75) & 488 & \\
\hline Compressive strength (psi) & 218.80 & Compressive strength (psi) & 186.35 & 202.58 \\
\hline
\end{tabular}




\section{Foundry Sand 28 day Strength}

Mix: M85FS 28 day

\begin{tabular}{|c|c|c|c|c|}
\hline Height & 5.541 & Height & 5.704 & AVG. \\
\hline Diameter (in) & 3.019 & Diameter (in) & 3.014 & \\
\hline Area $\quad\left(\mathrm{in}^{2}\right)$ & 7.1584 & Area $\quad\left(\mathrm{in}^{2}\right)$ & 7.1347 & \\
\hline Load number (lb/6.62) & 85 & Load number (lb/6.62) & 55 & \\
\hline Compressive strength (psi) & 78.606 & Compressive strength (psi) & 51.032 & 64.82 \\
\hline
\end{tabular}

Mix: M80FS 28 day

\begin{tabular}{|c|c|c|c|c|}
\hline Height (in) & 5.705 & Height & 5.515 & AVG. \\
\hline Diameter (in) & 3.015 & Diameter (in) & 3.011 & \\
\hline Area $\quad\left(\mathrm{in}^{2}\right)$ & 7.1394 & Area $\quad\left(\mathrm{in}^{2}\right)$ & 7.1205 & \\
\hline Load number (Ib/2.75) & 314 & Load number (lb/2.75) & 304 & \\
\hline Compressive strength (psi) & 120.94 & Compressive strength (psi) & 117.40 & 119.18 \\
\hline
\end{tabular}

Mix: M75FS 28 day

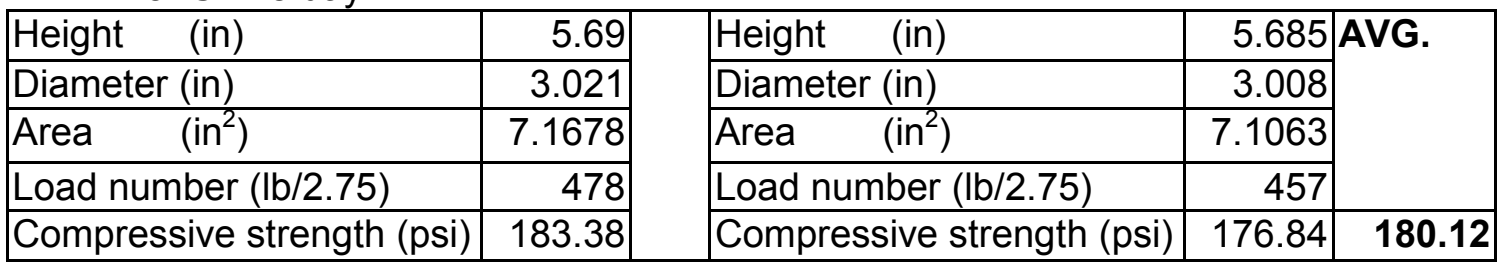

Mix: M50FS 28 day

\begin{tabular}{|c|c|c|c|c|}
\hline Height (in) & 5.789 & Height & 5.766 & AVG. \\
\hline Diameter (in) & 3.028 & Diameter (in) & 3.016 & \\
\hline Area $\quad\left(\mathrm{in}^{2}\right)$ & 7.2011 & Area $\quad\left(\mathrm{in}^{2}\right)$ & 7.1441 & \\
\hline Load number (Ib/6.62) & 230 & Load number (lb/6.62) & 246 & \\
\hline Compressive strength (psi) & 211.43 & Compressive strength (psi) & 227.95 & 219.69 \\
\hline
\end{tabular}

Mix: M25FS 28 day

\begin{tabular}{|c|c|c|c|c|}
\hline Height & 5.779 & Height & 5.553 & AVG. \\
\hline Diameter (in) & 3.023 & Diameter (in) & 3.027 & \\
\hline Area $\quad\left(\mathrm{in}^{2}\right)$ & 7.177 & Area $\quad\left(\mathrm{in}^{2}\right)$ & 7.196 & \\
\hline Load number (lb/6.62) & 278 & Load number (Ib/6.62) & 234 & \\
\hline Compressive strength (psi) & 256.41 & Compressive strength (psi) & 215.25 & 235.83 \\
\hline
\end{tabular}

Mix: M10FS 28 day

\begin{tabular}{|c|c|c|c|c|}
\hline Height (in) & 5.68 & Height & 5.751 & AVG. \\
\hline Diameter (in) & 3.015 & Diameter (in) & 3.025 & \\
\hline Area $\quad\left(\mathrm{in}^{2}\right)$ & 7.1394 & \begin{tabular}{|ll} 
Area & $\left(\mathrm{in}^{2}\right)$ \\
\end{tabular} & 7.1868 & \\
\hline Load number (Ib/6.62) & 238 & Load number (lb/6.62) & 251 & \\
\hline Compressive strength (psi) & 220.68 & Compressive strength (psi) & 231.20 & 225.94 \\
\hline
\end{tabular}




\section{Bottom Ash with $1 \%$ Cement 7 day Strength}

sample: M90BA1C 7 day

\begin{tabular}{|c|c|c|c|c|}
\hline Height & 5.583 & Height & 5.598 & AVG. \\
\hline Diameter (in) & 3.012 & Diameter (in) & 3.01 & \\
\hline Area $\quad\left(\mathrm{in}^{2}\right)$ & 7.1252 & Area $\quad\left(\mathrm{in}^{2}\right)$ & 7.1157 & \\
\hline Load number (Ib/2.75) & 353 & Load number (Ib/2.75) & 322 & \\
\hline Compressive strength (psi) & 136.24 & Compressive strength (psi) & 124.44 & 130.34 \\
\hline
\end{tabular}

Mix: M83BA1C 7 day

\begin{tabular}{|c|c|c|c|c|}
\hline Height & 5.586 & Height & 5.604 & AVG. \\
\hline Diameter (in) & 3.027 & Diameter (in) & 3.033 & \\
\hline Area $\quad\left(\mathrm{in}^{2}\right)$ & 7.1963 & Area $\quad\left(\mathrm{in}^{2}\right)$ & 7.2249 & \\
\hline Load number (lb/2.75) & 439 & Load number (lb/2.75) & 532 & \\
\hline Compressive strength (psi) & 167.75 & Compressive strength (psi) & 202.49 & 185.13 \\
\hline
\end{tabular}

Mix: M75BA1C 7 day

\begin{tabular}{|c|c|c|c|c|}
\hline Height & 5.71 & Height & 5.745 & AVG. \\
\hline Diameter (in) & 3.027 & Diameter (in) & 3.022 & \\
\hline Area $\quad\left(\mathrm{in}^{2}\right)$ & 7.1963 & Area $\quad\left(\mathrm{in}^{2}\right)$ & 7.1726 & \\
\hline Load number (lb/2.75) & 715 & Load number (Ib/2.75) & 663 & \\
\hline Compressive strength (psi) & 273.22 & Compressive strength (psi) & 254.19 & 263.71 \\
\hline
\end{tabular}

\section{River Sand with $1 \%$ Cement 7 day Strength}

Mix: M85RS1C 7 day

\begin{tabular}{|c|c|c|c|c|}
\hline Height (in) & 5.761 & Height & 5.739 & AVG. \\
\hline Diameter (in) & 3.025 & Diameter (in) & 3.015 & \\
\hline Area $\quad\left(\mathrm{in}^{2}\right)$ & 7.1868 & Area $\quad\left(\mathrm{in}^{2}\right)$ & 7.1394 & \\
\hline Load number (Ib/6.62) & 121 & Load number (Ib/6.62) & 111 & \\
\hline Compressive strength (psi) & 111.45 & Compressive strength (psi) & 102.924 & 107.19 \\
\hline
\end{tabular}

Mix: M80RS1C 7 day

\begin{tabular}{|c|c|c|c|c|}
\hline Height & 5.764 & Height & 5.799 & AVG. \\
\hline Diameter (in) & 3.026 & Diameter (in) & 3.024 & \\
\hline Area $\quad\left(\mathrm{in}^{2}\right)$ & 7.1916 & Area $\quad\left(\mathrm{in}^{2}\right)$ & 7.1821 & \\
\hline Load number (Ib/6.62) & 136 & Load number (Ib/6.62) & 176 & \\
\hline Compressive strength (psi) & 125.18 & Compressive strength (psi) & 162.22 & 43.71 \\
\hline
\end{tabular}

Mix: M75RS1C 7 day

\begin{tabular}{|c|c|c|c|c|}
\hline \multirow{2}{*}{$\begin{array}{l}\text { Height (in) } \\
\text { Diameter (in) }\end{array}$} & 5.786 & Height & \multirow{3}{*}{\begin{tabular}{|r|}
5.769 \\
3.021 \\
7.16789
\end{tabular}} & \multirow{3}{*}{ AVG. } \\
\hline & 3.031 & Diameter (in) & & \\
\hline Area $\quad\left(\mathrm{in}^{2}\right)$ & 7.2154 & Area $\quad\left(\mathrm{in}^{2}\right)$ & & \\
\hline Load number (lb/6.62) & 216 & Load number (Ib/6.62) & 238 & \\
\hline Compressive strength (psi) & 198.17 & Compressive strength (psi) & 219.80 & 208.99 \\
\hline
\end{tabular}


Bottom Ash with 1\% Cement 14 day Strength

Mix: M90BA1C 14day

\begin{tabular}{|c|c|c|c|c|}
\hline Height & 5.585 & Height & 5.622 & AVG. \\
\hline Diameter (in) & 3.026 & Diameter (in) & 3.018 & \\
\hline Area $\quad\left(\mathrm{in}^{2}\right)$ & 7.1916 & Area $\quad\left(\mathrm{in}^{2}\right)$ & 7.1536 & \\
\hline Load number (lb/6.62) & 424 & Load number (Ib/6.62) & 535 & \\
\hline Compressive strength (psi) & 390.29 & Compressive strength (psi) & 495.08 & 442.69 \\
\hline
\end{tabular}

Mix: M83BA1C 14day

\begin{tabular}{|c|c|c|c|c|}
\hline Height & 5.636 & Height & 5.637 & AVG. \\
\hline Diameter (in) & 3.031 & Diameter (in) & 3.038 & \\
\hline Area $\quad\left(\mathrm{in}^{2}\right)$ & 7.2154 & Area $\quad\left(\mathrm{in}^{2}\right)$ & 7.2487 & \\
\hline Load number (lb/6.62) & 581 & Load number (lb/6.62) & 398 & \\
\hline Compressive strength (psi) & 533.05 & Compressive strength (psi) & 363.47 & 448.27 \\
\hline
\end{tabular}

Mix: M75BA1C 14 day

\begin{tabular}{|c|c|c|c|c|}
\hline Height (in) & 5.729 & Height & 5.746 & AVG. \\
\hline Diameter (in) & 3.042 & Diameter (in) & 3.042 & \\
\hline Area $\quad\left(\mathrm{in}^{2}\right)$ & 7.2678 & Area $\quad\left(\mathrm{in}^{2}\right)$ & 7.2678 & \\
\hline Load number (Ib/6.62) & 620 & Load number (Ib/6.62) & 878 & \\
\hline Compressive strength (psi) & 564.73 & Compressive strength (psi) & 799.73 & 682.23 \\
\hline
\end{tabular}

\section{$\underline{\text { River Sand with 1\% Cement } 14 \text { day Strength }}$}

Mix: M85RS1C 14 day

\begin{tabular}{|c|c|c|c|c|}
\hline \multirow{2}{*}{$\begin{array}{l}\text { Height (in) } \\
\text { Diameter (in) }\end{array}$} & 5.718 & Height & 5.744 & \multirow[t]{3}{*}{ AVG. } \\
\hline & 3.018 & Diameter (in) & 3.012 & \\
\hline Area $\quad\left(\mathrm{in}^{2}\right)$ & 7.1536 & Area $\quad\left(\mathrm{in}^{2}\right)$ & 7.1252 & \\
\hline Load number (Ib/6.62) & 157 & Load number (Ib/6.62) & 116 & \\
\hline Compressive strength (psi) & 145.28 & Compressive strength (psi) & 107.77 & 126.53 \\
\hline
\end{tabular}

Mix: M80RS1C 14 day

\begin{tabular}{|c|c|c|c|c|}
\hline Height & 5.745 & Height & 5.808 & AVG. \\
\hline Diameter (in) & 3.016 & Diameter (in) & 3.024 & \\
\hline Area $\quad\left(\mathrm{in}^{2}\right)$ & 7.1441 & Area $\quad\left(\mathrm{in}^{2}\right)$ & 7.1821 & \\
\hline Load number (lb/6.62) & 174 & Load number (lb/6.62) & 230 & \\
\hline Compressive strength (psi) & 161.23 & Compressive strength (psi) & 211.99 & 186.6 \\
\hline
\end{tabular}

Mix: M75RS1C 14 day

\begin{tabular}{|c|c|c|c|c|}
\hline Height (in) & 5.804 & Height & 5.791 & AVG. \\
\hline Diameter (in) & 3.027 & Diameter (in) & 3.029 & \\
\hline Area $\quad\left(\mathrm{in}^{2}\right)$ & 7.1963 & Area $\quad\left(\mathrm{in}^{2}\right)$ & 7.2059 & \\
\hline Load number (lb/6.62) & 235 & \begin{tabular}{|l|} 
Load number (Ib/6.62) \\
\end{tabular} & 339 & \\
\hline Compressive strength (psi) & 216.177 & Compressive strength (psi) & 311.436 & 263.81 \\
\hline
\end{tabular}


Bottom Ash with 1\% Cement 28 day Strength

Mix: M90BA1C 28 day

\begin{tabular}{|c|c|c|c|c|}
\hline Height (in) & 5.684 & Height & 5.552 & AVG. \\
\hline Diameter (in) & 3.024 & Diameter (in) & 3.033 & \\
\hline Area $\quad\left(\right.$ in $\left.^{2}\right)$ & 7.1821 & Area $\quad\left(\mathrm{in}^{2}\right)$ & 7.2249 & \\
\hline oad number & 484 & Load number (l & 524 & \\
\hline Compressive strength (psi) & 446.11 & Compressive strength (psi) & 480.12 & 463.12 \\
\hline
\end{tabular}

Mix: M83BA1C 28 day

\begin{tabular}{|c|c|c|c|c|}
\hline Height & 5.668 & Height & 5.753 & AVG. \\
\hline Diameter (in) & 3.042 & Diameter (in) & 3.034 & \\
\hline Area $\quad\left(\mathrm{in}^{2}\right)$ & 7.2679 & Area $\quad\left(\mathrm{in}^{2}\right)$ & 7.2297 & \\
\hline Load number & 750 & Load number (It & 686 & \\
\hline Compressive strength (psi) & 683.14 & Compressive strength (psi) & 628.15 & \\
\hline
\end{tabular}

Mix: M75BA1C 28 day

\begin{tabular}{|c|c|c|c|c|}
\hline Height (in) & 5.682 & Height (in) & 5.737 & AVG. \\
\hline Diameter (in) & 3.026 & Diameter (in) & 3.034 & \\
\hline Area $\quad\left(\mathrm{in}^{2}\right)$ & 7.1916 & Area $\quad\left(\mathrm{in}^{2}\right)$ & 7.2297 & \\
\hline Load number (Ib/6.62) & 868 & Load number (Ib/6.62) & 1280 & \\
\hline Compressive strength (psi & 799.006 & Compressive strength (psi) & 1172.05 & 985.53 \\
\hline
\end{tabular}

\section{River Sand with $1 \%$ Cement 28 day Strength}

Mix: M85RS1C 28 day

\begin{tabular}{|c|c|c|c|}
\hline Height (in) & 5.732 & Height & 5.771 AVG. \\
\hline Diameter (in) & 3.022 & Diameter (in) & 3.021 \\
\hline Area $\quad\left(\mathrm{in}^{2}\right)$ & 7.1726 & Area $\quad\left(\mathrm{in}^{2}\right)$ & 7.1679 \\
\hline Load number ( & 163 & Load number (I & 129 \\
\hline Compressive strength (psi) & 150.44 & Compressive strength (psi) & 119.14 \\
\hline
\end{tabular}

Mix: M80RS1C 28 day

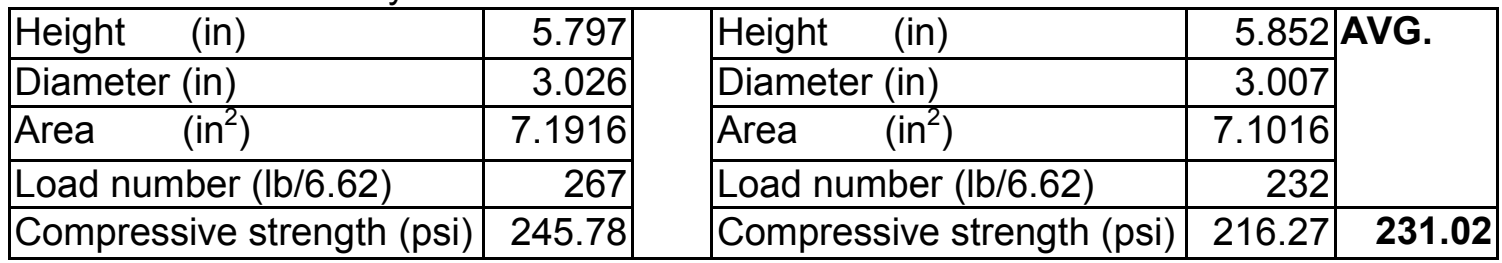

Mix: M75RS1C 28 day

\begin{tabular}{|c|c|c|c|c|}
\hline eight & 5.804 & Height & 5.813 & AVG. \\
\hline Diameter (in) & 3.023 & Diameter (in) & 3.031 & \\
\hline Area $\quad\left(\mathrm{in}^{2}\right)$ & 7.1774 & Area $\quad\left(\mathrm{in}^{2}\right)$ & 7.2154 & \\
\hline Load number (Ib/6.62) & 196 & Load number (Ib/6.62) & 266 & \\
\hline Compressive strength (psi) & 180.77 & Compressive strength (psi) & 244.049 & 212.41 \\
\hline
\end{tabular}


114

Foundry Sand with $1 \%$ Cement 7 day Strength

Mix: M85FS1C 7 day

\begin{tabular}{|c|c|c|c|c|}
\hline Height (in) & 5.594 & Height & 5.512 & AVG. \\
\hline Diameter (in) & 3.02 & Diameter (in) & 3.02 & \\
\hline Area $\quad\left(\mathrm{in}^{2}\right)$ & 7.1631 & Area $\quad\left(\mathrm{in}^{2}\right)$ & 7.1631 & \\
\hline Load number (Ib/2.75) & 210 & Load number (Ib/2.75) & 175 & \\
\hline Compressive strength (psi) & 80.621 & Compressive strength (psi) & 67.184 & 73.903 \\
\hline
\end{tabular}

Mix: M80FS1C 7 day

\begin{tabular}{|c|c|c|c|c|}
\hline Height & 5.569 & Height & 5.547 & AVG. \\
\hline Diameter (in) & 3.031 & Diameter (in) & 3.016 & \\
\hline Area $\quad\left(\mathrm{in}^{2}\right)$ & 7.2154 & Area $\quad\left(\mathrm{in}^{2}\right)$ & 7.1441 & \\
\hline Load number (lb/2.75) & 340 & Load number (lb/2.75) & 368 & \\
\hline Compressive strength (psi) & 129.58 & Compressive strength (psi) & 141.65 & 135.62 \\
\hline
\end{tabular}

Mix: M75FS1C 7 day

\begin{tabular}{|c|c|c|c|c|}
\hline Height & 5.692 & Height & 5.731 & AVG. \\
\hline Diameter (in) & 3.029 & Diameter (in) & 3.002 & \\
\hline Area $\quad\left(\mathrm{in}^{2}\right)$ & 7.2059 & Area $\quad\left(\mathrm{in}^{2}\right)$ & 7.0780 & \\
\hline Load number (Ib/3) & 550 & Load number (lb/3) & 531 & \\
\hline Compressive strength (psi) & 209.89 & Compressive strength (psi) & 206.30 & 208.1 \\
\hline
\end{tabular}

\section{Foundry Sand with 1\% Cement 14 day Strength}

Mix: M85FS1C 14 day

\begin{tabular}{|c|c|c|c|c|}
\hline Height (in) & 5.497 & Height & 5.612 & AVG. \\
\hline Diameter (in) & 3.012 & Diameter (in) & 3.025 & \\
\hline Area $\quad\left(\mathrm{in}^{2}\right)$ & 7.1252 & Area $\quad\left(\mathrm{in}^{2}\right)$ & 7.1868 & \\
\hline Load number (lb/6.62) & 89 & Load number (Ib/6.62) & 120 & \\
\hline Compressive strength (psi) & 82.689 & Compressive strength (psi) & 110.53 & 96.612 \\
\hline
\end{tabular}

Mix: M80FS1C 14 day

\begin{tabular}{|c|c|c|c|c|}
\hline Height & 5.605 & Height & 5.633 & AVG. \\
\hline Diameter (in) & 3.027 & Diameter (in) & 3.025 & \\
\hline Area $\quad\left(\mathrm{in}^{2}\right)$ & 7.1963 & Area $\quad\left(\mathrm{in}^{2}\right)$ & 7.1868 & \\
\hline Load number (lb/6.62) & 178 & Load number (Ib/6.62) & 154 & \\
\hline Compressive strength (psi) & 163.74 & Compressive strength (psi) & 141.85 & 152.8 \\
\hline
\end{tabular}

Mix: M75FS1C 14 day

\begin{tabular}{|c|c|c|c|c|}
\hline Height & 5.705 & Height & 5.704 & AVG. \\
\hline Diameter (in) & 3.034 & Diameter (in) & 3.029 & \\
\hline Area $\quad\left(\mathrm{in}^{2}\right)$ & 7.2297 & Area $\quad\left(\mathrm{in}^{2}\right)$ & 7.2059 & \\
\hline Load number (Ib/6.62) & 186 & Load number (Ib/6.62) & 209 & \\
\hline Compressive strength (psi) & 170.31 & Compressive strength (psi) & 192.00 & 181.16 \\
\hline
\end{tabular}


Foundry Sand with $1 \%$ Cement 28 day Strength

Mix: M85FS1C 28 day

\begin{tabular}{|c|c|c|c|c|}
\hline Height (in) & 5.677 & Height & 5.487 & AVG. \\
\hline Diameter (in) & 3.015 & Diameter (in) & 3.021 & \\
\hline Area $\quad\left(\mathrm{in}^{2}\right)$ & 7.1394 & Area $\quad\left(\mathrm{in}^{2}\right)$ & 7.1678 & \\
\hline Load number (Ib/6.62) & 140 & Load number (Ib/6.62) & 68 & \\
\hline Compressive strength (psi) & 129.814 & Compressive strength (psi) & 62.802 & 96.308 \\
\hline
\end{tabular}

Mix: M80FS1C 28 day

\begin{tabular}{|c|c|c|c|c|}
\hline Height (in) & 5.604 & Height & 5.606 & AVG. \\
\hline Diameter (in) & 3.03 & Diameter (in) & 3.022 & \\
\hline Area $\quad\left(\mathrm{in}^{2}\right)$ & 7.2106 & Area $\quad\left(\mathrm{in}^{2}\right)$ & 7.1726 & \\
\hline Load number (Ib/6.62) & 168 & Load number (lb/6.62) & 152 & \\
\hline Compressive strength (psi) & 154.23 & Compressive strength (psi) & 140.288 & 147.26 \\
\hline
\end{tabular}

Mix: M75FS1C 28 day

\begin{tabular}{|c|c|c|c|c|}
\hline \multirow{2}{*}{$\begin{array}{l}\text { Height (in) } \\
\text { Diameter (in) } \\
\end{array}$} & 5.709 & Height & \multirow{3}{*}{$\begin{array}{r}5.779 \\
3.029 \\
7.2059\end{array}$} & \multirow{4}{*}{ AVG. } \\
\hline & 3.031 & Diameter (in) & & \\
\hline Area $\quad\left(\mathrm{in}^{2}\right)$ & 7.2154 & Area $\quad\left(\mathrm{in}^{2}\right)$ & & \\
\hline Load number (Ib/6.62) & 232 & Load number (lb/6.62) & 218 & \\
\hline Compressive strength (psi) & 212.85 & Compressive strength (psi) & 200.27 & 206.56 \\
\hline
\end{tabular}




\section{$\underline{\text { Repeat Experiments }}$}

Mix: M75BA 7 day

\begin{tabular}{|c|c|c|c|c|}
\hline Height & 5.815 & Height & 5.84 & AVG. \\
\hline Diameter (in) & 3.028 & Diameter (in) & 3.033 & \\
\hline Area $\quad\left(\mathrm{in}^{2}\right)$ & 7.2011 & Area $\quad\left(\right.$ in $\left.^{2}\right)$ & 7.2249 & \\
\hline Load number (Ib/6.62) & 333 & Load number (lb/6.62) & 396 & \\
\hline Compressive strength (psi) & 306.12 & Compressive strength (psi) & 362.84 & 334.48 \\
\hline
\end{tabular}

Mix: M50BA 7 day

\begin{tabular}{|c|c|c|c|c|}
\hline Height (in) & 5.825 & Height (in) & 5.806 & AVG. \\
\hline Diameter (in) & 3.041 & Diameter (in) & 3.035 & \\
\hline Area $\quad\left(\mathrm{in}^{2}\right)$ & 7.2631 & Area $\quad\left(\mathrm{in}^{2}\right)$ & 7.2344 & \\
\hline Load number (Ib/6.62) & 656 & Load number (Ib/6.62) & 581 & \\
\hline Compressive strength (psi) & 597.91 & Compressive strength (psi) & 531.65 & 564.78 \\
\hline
\end{tabular}

Mix: M75RS 7 day

\begin{tabular}{|c|c|c|c|}
\hline \multirow{2}{*}{\begin{tabular}{|l|} 
Height (in) \\
Diameter (in) \\
\end{tabular}} & 5.803 & Height & \multirow{3}{*}{$\begin{array}{r}5.779 \\
3.018 \\
7.1536\end{array}$} \\
\hline & 3.015 & Diameter (in) & \\
\hline Area $\quad\left(\mathrm{in}^{2}\right)$ & 7.1394 & Area $\quad\left(\mathrm{in}^{2}\right)$ & \\
\hline Load number (Ib/6.62) & 216 & Load number (Ib/6.62) & 178 \\
\hline Compressive strength (psi) & 200.28 & Compressive strength (psi) & 164.72 \\
\hline
\end{tabular}

Mix: M50RS 7 day

\begin{tabular}{|c|c|c|c|c|}
\hline Height & 5.704 & Height & 5.769 & AVG. \\
\hline Diameter (in) & 3.016 & Diameter (in) & 3.029 & \\
\hline Area $\quad\left(\mathrm{in}^{2}\right)$ & 7.1441 & Area $\quad\left(\mathrm{in}^{2}\right)$ & 7.2059 & \\
\hline Load number (Ib/6.62) & 181 & Load number (Ib/6.62) & 248 & \\
\hline Compressive strength (psi) & 167.71 & Compressive strength (psi) & 227.83 & 197.78 \\
\hline
\end{tabular}

Mix: M83BA1C 7 day

\begin{tabular}{|c|c|c|c|c|}
\hline Height (in) & 5.788 & Height & 5.809 & AVG. \\
\hline Diameter (in) & 3.025 & Diameter (in) & 3.023 & \\
\hline Area $\quad\left(\mathrm{in}^{2}\right)$ & 7.1868 & Area $\quad\left(\mathrm{in}^{2}\right)$ & 7.1773 & \\
\hline Load number (Ib/6.62) & 203 & Load number (Ib/6.62) & 199 & \\
\hline Compressive strength (psi) & 186.98 & Compressive strength (psi) & 183.54 & 185.27 \\
\hline
\end{tabular}

Mix: M75BA1C 7 day

\begin{tabular}{|c|c|c|c|c|}
\hline Height (in) & 5.724 & Height (in) & 5.72 & AVG. \\
\hline Diameter (in) & 3.016 & Diameter (in) & 3.022 & \\
\hline Area $\quad\left(\mathrm{in}^{2}\right)$ & 7.1441 & Area $\quad\left(\mathrm{in}^{2}\right)$ & 7.1726 & \\
\hline Load number (Ib/6.62) & 297 & Load number (lb/6.62) & 303 & \\
\hline Compressive strength (psi) & 275.20 & Compressive strength (psi) & 279.654 & 277.43 \\
\hline
\end{tabular}




\section{$\underline{\text { Repeat Experiments }}$}

sample: M75BA 14 day

\begin{tabular}{|c|c|c|c|c|}
\hline \multirow{2}{*}{\begin{tabular}{|l|} 
Height (in) \\
Diameter (in)
\end{tabular}} & 5.813 & Height & 5.875 & \multirow{3}{*}{ AVG. } \\
\hline & 3.044 & Diameter (in) & 3.041 & \\
\hline Area $\quad\left(\mathrm{in}^{2}\right)$ & 7.2774 & Area $\quad\left(\mathrm{in}^{2}\right)$ & 7.2631 & \\
\hline Load number (Ib/6.62) & 830 & Load number (Ib/6.62) & 978 & \\
\hline Compressive strength (psi) & 755.01 & Compressive strength (psi) & 891.40 & 823.21 \\
\hline
\end{tabular}

Mix: M50BA 14 day

\begin{tabular}{|c|c|c|c|c|}
\hline Height & 5.858 & Height & 5.827 & AVG. \\
\hline Diameter (in) & 3.02 & Diameter (in) & 3.02 & \\
\hline Area $\quad\left(\mathrm{in}^{2}\right)$ & 7.1631 & Area $\quad\left(\mathrm{in}^{2}\right)$ & 7.1631 & \\
\hline Load number (Ib/6.62) & 776 & Load number (Ib/6.62) & 436 & \\
\hline Compressive strength (psi) & 717.15 & Compressive strength (psi) & 402.94 & 560.05 \\
\hline
\end{tabular}

Mix: M75RS 14 day

\begin{tabular}{|c|c|c|c|c|}
\hline Height & 5.857 & Height & 5.858 & AVG. \\
\hline Diameter (in) & 3.026 & Diameter (in) & 3.024 & \\
\hline Area $\quad\left(\mathrm{in}^{2}\right)$ & 7.1916 & Area $\quad\left(\mathrm{in}^{2}\right)$ & 7.1821 & \\
\hline Load number (Ib/6.62) & 196 & Load number (lb/6.62) & 215 & \\
\hline Compressive strength (psi) & 180.42 & Compressive strength (psi) & 198.17 & 189.3 \\
\hline
\end{tabular}

Mix: M50RS 14 day

\begin{tabular}{|c|c|c|c|c|}
\hline Height (in) & 5.757 & Height (in) & 5.777 & AVG. \\
\hline Diameter (in) & 3.042 & Diameter (in) & 3.033 & \\
\hline Area $\quad\left(\mathrm{in}^{2}\right)$ & 7.2678 & Area $\quad\left(\mathrm{in}^{2}\right)$ & 7.2249 & \\
\hline Load number (lb/6.62) & 355 & Load number (Ib/6.62) & 286 & \\
\hline Compressive strength (psi) & 323.35 & Compressive strength (psi) & 262.05 & 292.7 \\
\hline
\end{tabular}

Mix: M83BA1C 14 day

\begin{tabular}{|c|c|c|c|c|}
\hline Height & 5.815 & Height & 5.803 & AVG. \\
\hline Diameter (in) & 3.043 & Diameter (in) & 3.033 & \\
\hline Area $\quad\left(\mathrm{in}^{2}\right)$ & 7.2726 & Area $\quad\left(\mathrm{in}^{2}\right)$ & 7.2249 & \\
\hline Load number (lb/ & 720 & Load number (Ib/6.62) & 465 & \\
\hline Compressive strength (psi) & 655.38 & Compressive strength (psi) & 426.06 & 540.73 \\
\hline
\end{tabular}

Mix: M75BA1C 14 day

\begin{tabular}{|c|c|c|c|c|}
\hline \multirow{2}{*}{$\begin{array}{l}\text { Height (in) } \\
\text { Diameter (in) } \\
\end{array}$} & 5.746 & Height & 5.848 & \multirow{4}{*}{ AVG. } \\
\hline & 3.039 & Diameter (in) & 3.038 & \\
\hline Area $\quad\left(\mathrm{in}^{2}\right)$ & 7.2535 & Area $\quad\left(\mathrm{in}^{2}\right)$ & 7.2487 & \\
\hline Load number (lb/6.62) & 802 & Load number (lb/6.62) & 946 & \\
\hline Compressive strength (psi) & 731.94 & Compressive strength (psi) & 863.94 & 797.94 \\
\hline
\end{tabular}


Repeat Experiments

Mix: M75BA 28 day

\begin{tabular}{|c|c|c|c|}
\hline Height (in) & 5.773 & Height & 5.824 $\mid$ AVG. \\
\hline Diameter (in) & 3.035 & Diameter (in) & 3.031 \\
\hline Area $\quad\left(\mathrm{in}^{2}\right)$ & 7.2344 & Area $\quad\left(\mathrm{in}^{2}\right)$ & 7.2154 \\
\hline Load number (lb/6.62) & 1324 & Load number (Ib/6.62) & 1044 \\
\hline Compressive strength (psi & 1211.5 & Compressive strength (psi) & 957.84 \\
\hline
\end{tabular}

Mix: M50BA 28 day

\begin{tabular}{|c|c|c|c|}
\hline \multirow{2}{*}{$\begin{array}{ll}\text { Height } & \text { (in) } \\
\text { Diameter (in) } \\
\text { Area } \quad\left(\text { in }^{2}\right)\end{array}$} & 5.899 & Height (in) & 5.873 AVG. \\
\hline & 3.034 & Diameter (in) & 3.037 \\
\hline Area $\quad\left(\mathrm{in}^{2}\right)$ & 7.2297 & Area $\quad\left(\mathrm{in}^{2}\right)$ & 7.2440 \\
\hline Load number (II & 740 & Load number (Ib/6.62) & 796 \\
\hline Compressive strength (psi) & 677.59 & Compressive strength (psi & 727.43 \\
\hline
\end{tabular}

Mix: M75RS 28 day

\begin{tabular}{|c|c|c|c|c|}
\hline Height & 5.747 & Height & 5.803 & AVG. \\
\hline Diameter (in) & 3.024 & Diameter (in) & 3.016 & \\
\hline Area $\quad\left(i^{2}\right)$ & 7.1821 & Area $\quad\left(\mathrm{in}^{2}\right)$ & 7.1441 & \\
\hline Load number (I & 210 & Load number (Ib// & 239 & \\
\hline Compressive strength (psi) & 193.56 & Compressive strength (psi) & 221.46 & 207.51 \\
\hline
\end{tabular}

Mix: M50RS 28 day

\begin{tabular}{|c|c|c|c|c|}
\hline \multirow{2}{*}{$\begin{array}{l}\text { Height (in) } \\
\text { Diameter (in) }\end{array}$} & 5.78 & Height & \multicolumn{2}{|c|}{ 5.8|AVG. } \\
\hline & 3.031 & Diameter (in) & 3.031 & \\
\hline Area $\quad\left(\mathrm{in}^{2}\right)$ & 7.2154 & \begin{tabular}{|ll} 
Area & $\left(\mathrm{in}^{2}\right)$
\end{tabular} & 7.2154 & \\
\hline Load number (lb/6.62) & 375 & Load number (Ib/6 & 307 & \\
\hline Compressive strength (psi) & 344.05 & Compressive strength (psi) & 281.66 & 312.86 \\
\hline
\end{tabular}

Mix: M83BA1C 28 day

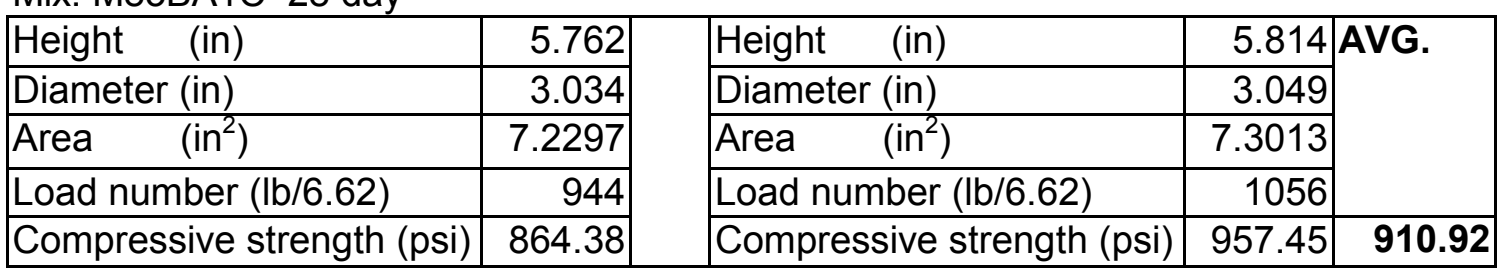

Mix: M75BA1C 28 day

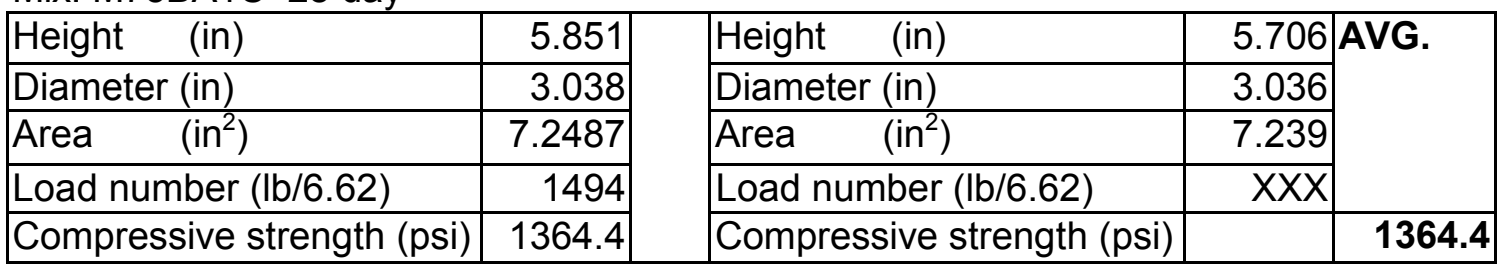


Bottom Ash with $2 \%$ Cement 7 day Strength

Mix: M40BA2C 7 day

\begin{tabular}{|c|c|c|c|c|}
\hline Height & 5.760 & Height & 5.715 & 5 |AVG. \\
\hline Diameter (in) & 3.042 & Diameter (in) & 3.041 & \\
\hline Area $\quad\left(\mathrm{in}^{2}\right)$ & 7.268 & Area $\quad\left(\mathrm{in}^{2}\right)$ & 7.263 & \\
\hline Load number (Ib/6.62) & 265.000 & Load number (lb/6.62) & 264.000 & \\
\hline Compressive strength (psi) & 241.377 & Compressive strength (psi) & 240.624 & 241 \\
\hline
\end{tabular}

Mix: M50BA2C 7 day

\begin{tabular}{|c|c|c|c|c|}
\hline Height (in) & 5.796 & Height & 5.802 & AVG. \\
\hline Diameter (in) & 3.038 & Diameter (in) & 3.037 & \\
\hline Area $\quad\left(\mathrm{in}^{2}\right)$ & 7.249 & Area $\quad\left(\mathrm{in}^{2}\right)$ & 7.244 & \\
\hline Load number (Ib/6.62) & 245.000 & Load number (lb/6.62) & 263.000 & \\
\hline Compressive strength (psi) & 223.748 & Compressive strength (psi) & 240.345 & 232.05 \\
\hline
\end{tabular}

Mix: M60BA2C 7 day

\begin{tabular}{|c|c|c|c|c|}
\hline Height & 5.742 & Height & 5.818 & AVG. \\
\hline Diameter (in) & 3.037 & Diameter (in) & 3.036 & \\
\hline Area $\quad\left(\mathrm{in}^{2}\right)$ & 7.244 & Area $\quad\left(\mathrm{in}^{2}\right)$ & 7.239 & \\
\hline Load number (Ib/6.62) & 390.000 & Load number (lb/6.62) & 311.000 & \\
\hline Compressive strength (psi) & 356.404 & Compressive strength (psi) & 284.397 & 320.4 \\
\hline
\end{tabular}

Mix: M70BA2C 7 day

\begin{tabular}{|c|c|c|c|c|}
\hline Height & 5.820 & Height & 5.735 & AVG. \\
\hline Diameter (in) & 3.029 & Diameter (in) & 3.025 & \\
\hline Area $\quad\left(\mathrm{in}^{2}\right)$ & 7.206 & Area $\quad\left(\mathrm{in}^{2}\right)$ & 7.187 & \\
\hline Load number (Ib/6.62) & 392.000 & Load number (Ib/6.62) & 400.000 & \\
\hline Compressive strength (psi) & 360.127 & Compressive strength (psi) & 368.449 & 364.29 \\
\hline
\end{tabular}

Mix: M80BA2C 7 day

\begin{tabular}{|c|c|c|c|c|}
\hline Height & 5.711 & Height (in) & 5.776 & AVG. \\
\hline Diameter (in) & 3.016 & Diameter (in) & 3.026 & \\
\hline Area $\quad\left(\mathrm{in}^{2}\right)$ & 7.144 & Area $\quad\left(\mathrm{in}^{2}\right)$ & 7.192 & \\
\hline Load number (Ib/6.62) & 307.000 & Load number (lb/6.62) & 269.000 & \\
\hline Compressive strength (psi) & 284.475 & Compressive strength (psi) & 247.618 & 266.05 \\
\hline
\end{tabular}


Bottom Ash with 2\% cement 14 day Strength

Mix: M40BA2C 14 day

\begin{tabular}{|c|c|c|c|c|}
\hline Height (in) & 5.649 & Height & 5.767 & AVG. \\
\hline Diameter (in) & 3.039 & Diameter (in) & 3.043 & \\
\hline Area $\quad\left(\mathrm{in}^{2}\right)$ & 7.254 & Area $\quad\left(\mathrm{in}^{2}\right)$ & 7.273 & \\
\hline Load number (Ib/6.62) & 646.000 & Load number (Ib/6.62) & 572.000 & \\
\hline Compressive strength (psi) & 589.575 & Compressive strength (psi) & 520.667 & 555.12 \\
\hline
\end{tabular}

Mix: M50BA2C 14 day

\begin{tabular}{|c|c|c|c|c|}
\hline \multirow{2}{*}{$\begin{array}{l}\text { Height (in) } \\
\text { Diameter (in) }\end{array}$} & 5.840 & Height & 5.764 & \multirow{4}{*}{ AVG. } \\
\hline & 3.046 & Diameter (in) & 3.034 & \\
\hline Area $\quad\left(\mathrm{in}^{2}\right)$ & 7.287 & Area $\quad\left(\mathrm{in}^{2}\right)$ & 7.230 & \\
\hline Load number (lb/6.62) & 845.000 & Load number (Ib/6.62) & 655.000 & \\
\hline Compressive strength (psi) & 767.653 & Compressive strength (psi) & 599.761 & 683.71 \\
\hline
\end{tabular}

Mix: M60BA2C 14 day

\begin{tabular}{|c|c|c|c|c|}
\hline \multirow{2}{*}{$\begin{array}{l}\text { Height (in) } \\
\text { Diameter (in) }\end{array}$} & 5.841 & Height & 5.757 & \multirow{4}{*}{ AVG. } \\
\hline & 3.044 & Diameter (in) & 3.048 & \\
\hline Area $\quad\left(\mathrm{in}^{2}\right)$ & 7.277 & Area $\quad\left(\mathrm{in}^{2}\right)$ & 7.297 & \\
\hline Load number (Ib/6.62) & 830.000 & Load number (lb/6.62) & 691.000 & \\
\hline Compressive strength (psi) & 755.017 & Compressive strength (psi) & 626.926 & 690.97 \\
\hline
\end{tabular}

Mix: M70BA2C 14 day

\begin{tabular}{|c|c|c|c|c|}
\hline \multirow{2}{*}{$\begin{array}{l}\text { Height (in) } \\
\text { Diameter (in) }\end{array}$} & 5.831 & Height & 5.795 & \multirow{4}{*}{ AVG. } \\
\hline & 3.044 & Diameter (in) & 3.052 & \\
\hline Area $\quad\left(\mathrm{in}^{2}\right)$ & 7.277 & Area $\quad\left(\mathrm{in}^{2}\right)$ & 7.316 & \\
\hline Load number (Ib/6.62) & 1078.00 & Load number (Ib/6.62) & 978.000 & \\
\hline Compressive strength (psi) & 980.613 & Compressive strength (psi) & 884.989 & 932.8 \\
\hline
\end{tabular}

Mix: M80BA2C 14 day

\begin{tabular}{|c|c|c|c|c|}
\hline Height $\quad$ (in) & 5.802 & Height (in) & 5.683 & AVG. \\
\hline Diameter (in) & 3.034 & Diameter (in) & 3.049 & \\
\hline Area $\quad\left(\mathrm{in}^{2}\right)$ & 7.230 & Area $\quad\left(\mathrm{in}^{2}\right)$ & 7.301 & \\
\hline Load number (Ib/6.62) & 603.000 & Load number (Ib/6.62) & 788.000 & \\
\hline Compressive strength (psi) & 552.146 & Compressive strength (psi) & 714.463 & 633.3 \\
\hline
\end{tabular}


Bottom Ash with $2 \%$ cement 28 day Strength

Mix: M40BA2C 28 day

\begin{tabular}{|c|c|c|c|c|}
\hline \multirow{2}{*}{\begin{tabular}{|l|} 
Height (in) \\
Diameter (in)
\end{tabular}} & 5.595 & Height (in) & \multirow{2}{*}{\begin{tabular}{l|l}
5.728 & AVG. \\
3.044 &
\end{tabular}} & \multirow{4}{*}{ AVG. } \\
\hline & 3.037 & Diameter (in) & & \\
\hline Area $\quad\left(\mathrm{in}^{2}\right)$ & 7.244 & Area $\quad\left(\mathrm{in}^{2}\right)$ & 7.277 & \\
\hline Load number (Ib/6.62) & 765.000 & Load number (Ib/6.62) & 463.000 & \\
\hline Compressive strength (psi) & 699.101 & Compressive strength (psi) & 421.172 & 560.14 \\
\hline
\end{tabular}

Mix: M50BA2C 28 day

\begin{tabular}{|c|c|c|c|c|}
\hline Height & 5.768 & Height & 5.781 & AVG. \\
\hline Diameter (in) & 3.040 & Diameter (in) & 3.039 & \\
\hline Area $\quad\left(\mathrm{in}^{2}\right)$ & 7.258 & $a \quad\left(\mathrm{in}^{2}\right)$ & 7.254 & \\
\hline Load number (Ib/6.62) & 800.000 & Load number (Ib/6.62) & 1051.000 & \\
\hline Compressive strength (psi) & 729.644 & Compressive strength (psi) & 959.201 & 844.42 \\
\hline
\end{tabular}

Mix: M60BA2C 28 day

\begin{tabular}{|c|c|c|c|c|}
\hline \multirow{2}{*}{$\frac{\text { Height (in) }}{\text { Diameter (in) }}$} & 5.900 & Height & 5.783 & \multirow{4}{*}{ AVG. } \\
\hline & 3.035 & Diameter (in) & 3.039 & \\
\hline Area $\quad\left(\mathrm{in}^{2}\right)$ & 7.234 & Area $\quad\left(\mathrm{in}^{2}\right)$ & 7.254 & \\
\hline Load number (Ib/6.62) & 1028.000 & Load number (Ib/6.62) & 820.000 & \\
\hline Compressive strength (psi) & 940.684 & Compressive strength (psi) & 748.377 & 844.53 \\
\hline
\end{tabular}

Mix: M70BA2C 28 day

\begin{tabular}{|c|c|c|c|c|}
\hline Height & 5.840 & Height & 5.807 & AVG. \\
\hline Diameter (in) & 3.041 & Diameter (in) & 3.045 & \\
\hline$a \quad\left(\mathrm{in}^{2}\right)$ & 7.263 & $\left(\mathrm{in}^{2}\right)$ & 7.282 & \\
\hline Load number (lb/6.62) & 1401.000 & Load number (Ib/6.62) & 1478.000 & \\
\hline Compressive strength (psi) & 1276.949 & Compressive strength (psi) & 1343.594 & 1310.3 \\
\hline
\end{tabular}

Mix: M80BA2C 28 day

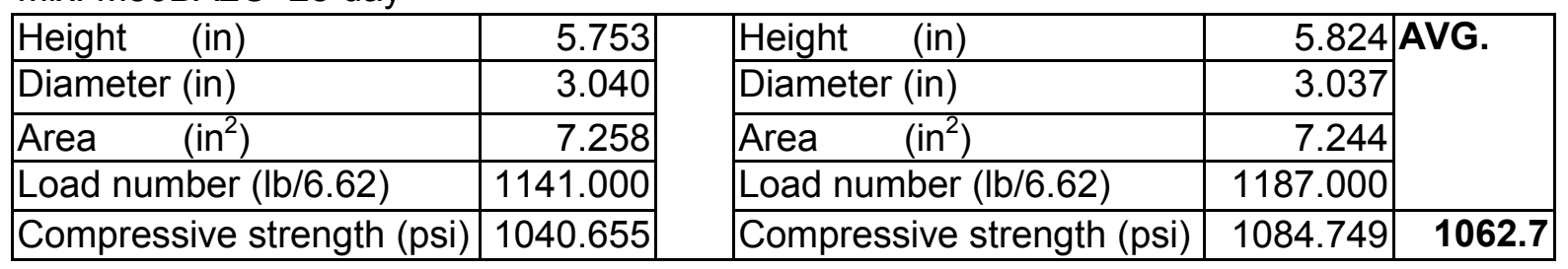




\section{Bottom Ash with $3 \%$ Cement 7 day Strength}

Mix: M40BA3C 7 day

\begin{tabular}{|c|c|c|c|c|}
\hline Height (in) & 5.698 & Height(in) 2: & 5.705 & AVG. \\
\hline Diameter (in) & 3.042 & Diameter(in) 2: & 3.044 & \\
\hline Area $\quad\left(\mathrm{in}^{2}\right)$ & 7.268 & Area $\left(\mathrm{in}^{2}\right) 2:$ & 7.277 & \\
\hline Load number (Ib/6.62) & 314.0 & Load number (Ib/6.62) & 356.00 & \\
\hline Compressive strength (psi) & 286.009 & Compressive strength (psi) & 323.83 & 304.92 \\
\hline
\end{tabular}

Mix: M50BA3C 7 day

\begin{tabular}{|c|c|c|c|c|}
\hline Height & 5.769 & Height & 5.655 & AVG. \\
\hline Diameter (in) & 3.024 & Diameter (in) & 3.022 & \\
\hline Area $\quad\left(\mathrm{in}^{2}\right)$ & 7.182 & Area $\quad\left(\mathrm{in}^{2}\right)$ & 7.173 & \\
\hline Load number (Ib/6.62) & 296.000 & Load number (lb/6.62) & 329.0 & \\
\hline Compressive strength (psi) & 272.833 & Compressive strength (psi) & 303.65 & 288.24 \\
\hline
\end{tabular}

Mix: M60BA3C 7 day

\begin{tabular}{|c|c|c|c|c|}
\hline Height & 5.743 & Height & 5.746 & AVG. \\
\hline Diameter (in) & 3.029 & Diameter (in) & 3.026 & \\
\hline Area $\quad\left(\mathrm{in}^{2}\right)$ & 7.206 & Area $\quad\left(\mathrm{in}^{2}\right)$ & 7.192 & \\
\hline Load number (Ib/6.62) & 318.0 & Load number (Ib/6.62) & 283.0 & \\
\hline Compressive strength (psi) & 292.144 & Compressive strength (psi) & 260.50 & 276.32 \\
\hline
\end{tabular}

Mix: M70BA3C 7 day

\begin{tabular}{|c|c|c|c|c|}
\hline Height & 5.744 & Height (in) & 5.816 & AVG. \\
\hline Diameter (in) & 3.029 & Diameter (in) & 3.031 & \\
\hline Area $\quad\left(\mathrm{in}^{2}\right)$ & 7.206 & Area $\quad\left(\mathrm{in}^{2}\right)$ & 7.215 & \\
\hline Load number (Ib/6.62) & 336.0 & Load number (lb/6.62) & 428.0 & \\
\hline Compressive strength (psi) & 308.680 & Compressive strength (psi) & 392.68 & 350.68 \\
\hline
\end{tabular}

Mix: M80BA3C 7 day

\begin{tabular}{|c|c|c|c|c|}
\hline Height & 5.650 & Height & 5.723 & AVG. \\
\hline Diameter (in) & 3.018 & Diameter (in) & 3.013 & \\
\hline Area $\quad\left(\mathrm{in}^{2}\right)$ & 7.154 & Area $\quad\left(\mathrm{in}^{2}\right)$ & 7.130 & \\
\hline Load number (lb/6.62) & 445.0 & Load number (lb/6.62) & 356.0 & \\
\hline Compressive strength (psi) & 411.803 & Compressive strength (psi) & 330.53 & 371.17 \\
\hline
\end{tabular}


Bottom Ash with 3\% cement 14 day Strength

Mix: M40BA3C 14 day

\begin{tabular}{|c|c|c|c|c|}
\hline Height & 5.862 & Height & 5.741 & AVG. \\
\hline Diameter (in) & 3.024 & Diameter (in) & 3.040 & \\
\hline Area $\quad\left(\mathrm{in}^{2}\right)$ & 7.182 & Area $\quad\left(\mathrm{in}^{2}\right)$ & 7.258 & \\
\hline Load number (lb/6.62) & 574.000 & Load number (Ib/6.62) & 381.000 & \\
\hline Compressive strength (psi) & 529.074 & Compressive strength (psi) & 347.493 & 438.28 \\
\hline
\end{tabular}

Mix: M50BA3C 14 day

\begin{tabular}{|c|c|c|c|c|}
\hline Height & 5.749 & Height & 5.741 & AVG. \\
\hline Diameter (in) & 3.035 & Diameter (in) & 3.038 & \\
\hline Area $\quad\left(\mathrm{in}^{2}\right)$ & 7.234 & Area $\quad\left(\mathrm{in}^{2}\right)$ & 7.249 & \\
\hline Load number (Ib/6.62) & 666.000 & Load number (Ib/6.62) & 892.000 & \\
\hline Compressive strength (psi) & 609.432 & Compressive strength (psi) & 814.624 & 712.03 \\
\hline
\end{tabular}

Mix: M60BA3C 14 day

\begin{tabular}{|c|c|c|c|c|}
\hline Height & 5.768 & Height & 5.742 & AVG. \\
\hline Diameter (in) & 3.038 & Diameter (in) & 3.041 & \\
\hline Area $\quad\left(\mathrm{in}^{2}\right)$ & 7.249 & Area $\quad\left(\mathrm{in}^{2}\right)$ & 7.263 & \\
\hline Load number (Ib/6.62) & 998.000 & Load number (Ib/6.62) & 1014.000 & \\
\hline Compressive strength (psi) & 911.430 & Compressive strength (psi) & 924.215 & 917.82 \\
\hline
\end{tabular}

Mix: M70BA3C 14 day

\begin{tabular}{|c|c|c|c|c|}
\hline Height (in) & 5.763 & Height & 5.757 & AVG. \\
\hline Diameter (in) & 3.048 & Diameter (in) & 3.048 & \\
\hline Area $\quad\left(\mathrm{in}^{2}\right)$ & 7.297 & Area $\quad\left(\mathrm{in}^{2}\right)$ & 7.297 & \\
\hline Load number (Ib/6.62) & 919.000 & Load number (Ib/6.62) & 731.000 & \\
\hline Compressive strength (psi) & 833.784 & Compressive strength (psi) & 663.217 & 748.5 \\
\hline
\end{tabular}

Mix: M80BA3C 14 day

\begin{tabular}{|c|c|c|c|c|}
\hline Height (in) & 5.801 & Height & 5.791 & AVG. \\
\hline Diameter (in) & 3.032 & Diameter (in) & 3.034 & \\
\hline Area $\quad\left(\mathrm{in}^{2}\right)$ & 7.220 & Area $\quad\left(\mathrm{in}^{2}\right)$ & 7.230 & \\
\hline Load number (lb/6.62) & 465.000 & Load number (Ib/6.62) & 769.000 & \\
\hline Compressive strength (psi) & 426.346 & Compressive strength (psi) & 704.147 & 565.25 \\
\hline
\end{tabular}




\section{Bottom Ash with 3\% Cement 28 day Strength}

Mix: M40BA3C 28 day

\begin{tabular}{|c|c|c|c|c|}
\hline \multirow{2}{*}{$\begin{array}{l}\text { Height (in) } \\
\text { Diameter (in) }\end{array}$} & 5.804 & Height & 5.799 & \multirow{4}{*}{ AVG. } \\
\hline & 3.041 & Diameter (in) & 3.041 & \\
\hline Area $\quad\left(\mathrm{in}^{2}\right)$ & 7.263 & Area $\quad\left(\mathrm{in}^{2}\right)$ & 7.263 & \\
\hline Load number (Ib/6.62) & 491.000 & Load number (Ib/6.62) & 746.000 & \\
\hline Compressive strength (psi) & 447.524 & Compressive strength (psi) & 679.945 & 563.73 \\
\hline
\end{tabular}

Mix: M50BA3C 28 day

\begin{tabular}{|c|c|c|c|c|}
\hline \multirow{2}{*}{\begin{tabular}{|l} 
Height (in) \\
Diameter (in)
\end{tabular}} & 5.742 & Height & 5.710 & \multirow{4}{*}{ AVG. } \\
\hline & 3.039 & Diameter (in) & 3.035 & \\
\hline Area $\quad\left(\mathrm{in}^{2}\right)$ & 7.254 & Area $\quad\left(\mathrm{in}^{2}\right)$ & 7.234 & \\
\hline Load number (Ib/6.62) & 754.000 & Load number (Ib/6.62) & 593.000 & \\
\hline Compressive strength (psi) & 688.142 & Compressive strength (psi) & 542.632 & 615.39 \\
\hline
\end{tabular}

Mix: M60BA3C 28 day

\begin{tabular}{|c|c|c|c|c|}
\hline Height (in) & 5.752 & Height (in) & 5.831 & AVG. \\
\hline Diameter (in) & 3.037 & Diameter (in) & 3.038 & \\
\hline Area $\quad\left(\mathrm{in}^{2}\right)$ & 7.244 & Area $\quad\left(\mathrm{in}^{2}\right)$ & 7.249 & \\
\hline Load number (lb/6.62) & 723.000 & Load number (Ib/6.62) & 911.000 & \\
\hline Compressive strength (psi) & 660.719 & Compressive strength (psi) & 831.976 & 746.35 \\
\hline
\end{tabular}

Mix: M70BA3C 28 day

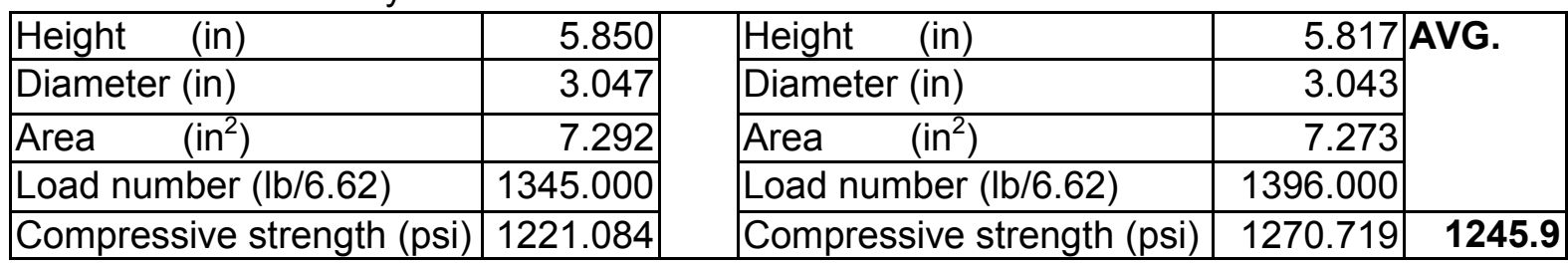

Mix: M80BA3C 28 day

\begin{tabular}{|c|c|c|c|c|}
\hline Height & 5.785 & Height & 5.726 & AVG. \\
\hline Diameter (in) & 3.037 & Diameter (in) & 3.034 & \\
\hline Area $\quad\left(\mathrm{in}^{2}\right)$ & 7.244 & Area $\quad\left(\mathrm{in}^{2}\right)$ & 7.230 & \\
\hline Load number (Ib/6.62) & 1185.000 & Load number (Ib/6.62) & 1106.000 & \\
\hline Compressive strength (psi) & 1082.921 & Compressive strength (psi) & 1012.726 & 1047.8 \\
\hline
\end{tabular}


Bottom Ash with $4 \%$ Cement 7 day Strength

Mix: M40BA4C 7 day

\begin{tabular}{|c|c|c|c|c|}
\hline \multirow{2}{*}{$\begin{array}{l}\text { Height } \quad \text { (in) } \\
\text { Diameter (in) }\end{array}$} & 5.766 & Height & \multirow{3}{*}{\begin{tabular}{l|l}
5.680 & AVG. \\
3.033 &
\end{tabular}} & \multirow{3}{*}{ AVG. } \\
\hline & 3.034 & Diameter (in) & & \\
\hline Area $\quad\left(\mathrm{in}^{2}\right)$ & 7.230 & Area $\quad\left(\mathrm{in}^{2}\right)$ & & \\
\hline Load number (lb/6.62) & 317.000 & Load number (lb/6.62) & 492.000 & \\
\hline Compressive strength (psi) & 290.266 & Compressive strength (psi) & 450.805 & 370.54 \\
\hline
\end{tabular}

Mix: M50BA4C 7 day

\begin{tabular}{|c|c|c|c|c|}
\hline Height & 5.718 & Height & 5.731 & AVG. \\
\hline Diameter (in) & 3.030 & Diameter (in) & 3.035 & \\
\hline Area $\quad\left(\mathrm{in}^{2}\right)$ & 7.211 & Area $\quad\left(\mathrm{in}^{2}\right)$ & 7.234 & \\
\hline Load number (Ib/6.62) & 425.000 & Load number (lb/6.62) & 495.000 & \\
\hline Compressive strength (psi) & 390.186 & Compressive strength (psi) & 452.956 & 421.57 \\
\hline
\end{tabular}

Mix: M60BA4C 7 day

\begin{tabular}{|c|c|c|c|c|}
\hline Height (in) & 5.813 & Height & 5.751 & AVG. \\
\hline Diameter (in) & 3.030 & Diameter (in) & 3.022 & \\
\hline Area $\quad\left(\mathrm{in}^{2}\right)$ & 7.211 & Area $\quad\left(\mathrm{in}^{2}\right)$ & 7.173 & \\
\hline Load number (lb/6.62) & 454.000 & Load number (Ib/6.62) & 535.000 & \\
\hline Compressive strength (psi) & 416.811 & Compressive strength (psi) & 493.779 & 455.29 \\
\hline
\end{tabular}

Mix: M70BA4C 7 day

\begin{tabular}{|c|c|c|c|c|}
\hline \multirow{2}{*}{$\begin{array}{l}\text { Height (in) } \\
\text { Diameter (in) } \\
\end{array}$} & 5.647 & Height & 5.690 & \multirow[t]{3}{*}{ AVG. } \\
\hline & 3.017 & Diameter (in) & 3.021 & \\
\hline Area $\quad\left(\mathrm{in}^{2}\right)$ & 7.149 & Area $\quad\left(\mathrm{in}^{2}\right)$ & 7.168 & \\
\hline Load number (Ib/6.62) & 457.000 & Load number (lb/6.62) & 512.000 & \\
\hline Compressive strength (psi) & 423.188 & Compressive strength (psi) & 472.864 & 448.03 \\
\hline
\end{tabular}

Mix: M80BA4C 7 day

\begin{tabular}{|c|c|c|c|c|}
\hline Height & 5.797 & Height & 5.799 & AVG. \\
\hline Diameter (in) & 3.026 & Diameter (in) & 3.027 & \\
\hline Area $\quad\left(\mathrm{in}^{2}\right)$ & 7.192 & Area $\quad\left(\mathrm{in}^{2}\right)$ & 7.196 & \\
\hline Load number (lb/6.62) & 588.000 & Load number (lb/6.62) & 558.000 & \\
\hline Compressive strength (psi) & 541.262 & Compressive strength (psi) & 513.307 & 527.28 \\
\hline
\end{tabular}


Bottom Ash with 4\% Cement 14 day Strength

Mix: M40BA4C 14 day

\begin{tabular}{|c|c|c|c|c|}
\hline \multirow{2}{*}{\begin{tabular}{|l|} 
Height (in) \\
Diameter (in)
\end{tabular}} & 5.734 & Height & 5.705 & \multirow{3}{*}{ AVG. } \\
\hline & 3.027 & Diameter (in) & 3.037 & \\
\hline Area $\quad\left(\mathrm{in}^{2}\right)$ & 7.196 & Area $\quad\left(\mathrm{in}^{2}\right)$ & 7.244 & \\
\hline Load number (Ib/6.62) & 802.000 & Load number (Ib/6.62) & 914.000 & \\
\hline Compressive strength (psi) & 737.764 & Compressive strength (psi) & 835.266 & 786.52 \\
\hline
\end{tabular}

Mix: M50BA4C 14 day

\begin{tabular}{|c|c|c|c|c|}
\hline Height (in) & 5.686 & Height & 5.803 & AVG. \\
\hline Diameter (in) & 3.036 & Diameter (in) & 3.029 & \\
\hline Area $\quad\left(\mathrm{in}^{2}\right)$ & 7.239 & Area $\quad\left(\mathrm{in}^{2}\right)$ & 7.206 & \\
\hline Load number (lb/6.62) & $\begin{array}{r}1018.00 \\
0\end{array}$ & Load number (lb/6.62) & 1155.000 & \\
\hline Compressive strength (psi) & 930.920 & Compressive strength (psi) & 1061.088 & 996 \\
\hline
\end{tabular}

Mix: M60BA4C 14 day

\begin{tabular}{|c|c|c|c|c|}
\hline Height & 5.872 & Height & 5.722 & AVG. \\
\hline Diameter (in) & 3.044 & Diameter (in) & 3.034 & \\
\hline Area $\quad\left(\mathrm{in}^{2}\right)$ & 7.277 & Area $\quad\left(\mathrm{in}^{2}\right)$ & 7.230 & \\
\hline Load number (Ib/6.62) & 887.000 & Load number (Ib/6.62) & 1042.000 & \\
\hline Compressive strength (psi) & 806.868 & Compressive strength (psi) & 954.124 & 880.5 \\
\hline
\end{tabular}

Mix: M70BA4C 14 day

\begin{tabular}{|c|c|c|c|c|}
\hline Height (in) & 5.815 & Height & 5.747 & AVG. \\
\hline Diameter (in) & 3.039 & Diameter (in) & 3.038 & \\
\hline Area $\quad\left(\mathrm{in}^{2}\right)$ & 7.254 & Area $\quad\left(\mathrm{in}^{2}\right)$ & 7.249 & \\
\hline Load number (Ib/6.62) & 806.000 & Load number (Ib/6.62) & 1074.000 & \\
\hline Compressive strength (psi) & 735.600 & Compressive strength (psi) & 980.837 & 858.22 \\
\hline
\end{tabular}

Mix: M80BA4C 14 day

\begin{tabular}{|c|c|c|c|c|}
\hline Height (in) & 5.780 & Height & 5.759 & AVG. \\
\hline Diameter (in) & 3.034 & Diameter (in) & 3.046 & \\
\hline Area $\quad\left(\mathrm{in}^{2}\right)$ & 7.230 & Area $\quad\left(\mathrm{in}^{2}\right)$ & 7.287 & \\
\hline Load number (Ib/6.62) & 833.000 & Load number (Ib/6.62) & 832.000 & \\
\hline Compressive strength (psi) & 762.750 & Compressive strength (psi) & 755.843 & 759.3 \\
\hline
\end{tabular}


Bottom Ash with 4\% Cement 28 day Strength

Mix: M40BA4C 28 day

\begin{tabular}{|c|c|c|c|c|}
\hline Height & 5.763 & Height & 5.706 & AVG. \\
\hline Diameter (in) & 3.030 & Diameter (in) & 3.034 & \\
\hline Area $\quad\left(\mathrm{in}^{2}\right)$ & 7.211 & Area $\quad\left(\mathrm{in}^{2}\right)$ & 7.230 & \\
\hline Load number (Ib/6.62) & 952.000 & Load number (Ib/6.62) & 753.000 & \\
\hline Compressive strength (psi) & 874.017 & Compressive strength (psi) & 689.496 & 781.76 \\
\hline
\end{tabular}

Mix: M50BA4C 28 day

\begin{tabular}{|c|c|c|c|c|}
\hline \multirow{2}{*}{$\frac{\text { Height (in) }}{\text { Diameter (in) }}$} & 5.558 & Height & 5.721 & \multirow{4}{*}{ AVG. } \\
\hline & 3.025 & Diameter (in) & 3.027 & \\
\hline Area $\quad\left(\mathrm{in}^{2}\right)$ & 7.187 & Area $\quad\left(\mathrm{in}^{2}\right)$ & 7.196 & \\
\hline Load number (Ib/6.62) & 1029.000 & Load number (Ib/6.62) & 1002.000 & \\
\hline Compressive strength (psi) & 947.835 & Compressive strength (psi) & 921.745 & 934.79 \\
\hline
\end{tabular}

Mix: M60BA4C 28 day

\begin{tabular}{|c|c|c|c|c|}
\hline \multirow{2}{*}{$\frac{\text { Height (in) }}{\text { Diameter (in) }}$} & 5.750 & Height & 5.768 & \multirow{4}{*}{ AVG. } \\
\hline & 3.029 & Diameter (in) & 3.025 & \\
\hline Area $\quad\left(\mathrm{in}^{2}\right)$ & 7.206 & Area $\quad\left(\mathrm{in}^{2}\right)$ & 7.187 & \\
\hline Load number (Ib/6.62) & 1139.000 & Load number (Ib/6.62) & 1220.000 & \\
\hline Compressive strength (psi) & 1046.389 & Compressive strength (psi) & 1123.769 & 1085.1 \\
\hline
\end{tabular}

Mix: M70BA4C 28 day

\begin{tabular}{|c|c|c|c|c|}
\hline Height (in) & 5.764 & Height & 5.795 & AVG. \\
\hline Diameter (in) & 3.029 & Diameter (in) & 3.030 & \\
\hline Area $\quad\left(\mathrm{in}^{2}\right)$ & 7.206 & Area $\quad\left(\mathrm{in}^{2}\right)$ & 7.211 & \\
\hline Load number (Ib/6.62) & $\mathrm{XXXX}$ & Load number (Ib/6.62) & $\mathrm{XXXX}$ & \\
\hline Compressive strength (psi) & & Compressive strength (psi) & & $\mathbf{X X X X}$ \\
\hline
\end{tabular}

Mix: M80BA4C 28 day

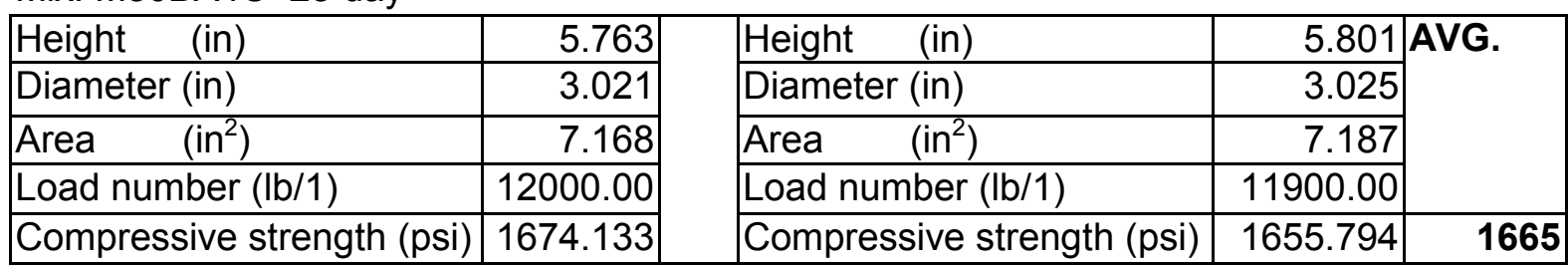




\section{Penetration Resistance Testing}

M90BA

\begin{tabular}{|c|r|r|r|r|r|r|}
\hline time & $2 \mathrm{hr}$ & $4 \mathrm{hr}$ & $8 \mathrm{hr}$ & $12 \mathrm{hr}$ & $24 \mathrm{hr}$ & 14 day \\
\hline area $\left(\mathrm{in}^{2}\right)$ & 0.75 & 1 & 0.5 & 0.2 & 0.1 & 0.025 \\
\hline 1 & 18 & 38 & 26 & 22 & 32 & Over \\
\hline 2 & 12 & 35 & 22 & 30 & 30 & mechanical \\
\hline 3 & 12 & 38 & 22 & 24 & 26 & limit \\
\hline avg $(\mathrm{psi})$ & 18.66667 & 37 & 46.66667 & 126.6667 & 293.3333 & \\
\hline
\end{tabular}

\section{M83BA}

\begin{tabular}{|c|r|r|r|r|r|r|}
\hline time & $2 \mathrm{hr}$ & $4 \mathrm{hr}$ & $8 \mathrm{hr}$ & $12 \mathrm{hr}$ & $24 \mathrm{hr}$ & 14day \\
\hline Area $\left(\mathrm{in}^{2}\right)$ & 1 & 1 & 0.5 & 0.2 & 0.1 & 0.025 \\
\hline 1 & 26 & 34 & 34 & 25 & 26 & Over \\
\hline 2 & 22 & 36 & 32 & 22 & 24 & mechanical \\
\hline 3 & 23 & 42 & 30 & 23 & 25 & limit \\
\hline Avg (psi) & 23.66667 & 37.33333 & 64 & 116.6667 & 250 & \\
\hline
\end{tabular}

\section{M75BA}

\begin{tabular}{|c|r|r|r|r|r|r|}
\hline time & $2 \mathrm{hr}$ & $4 \mathrm{hr}$ & $8 \mathrm{hr}$ & $12 \mathrm{hr}$ & $24 \mathrm{hr}$ & $14 \mathrm{day}$ \\
\hline Area $\left(\mathrm{in}^{2}\right)$ & 1 & 1 & 0.5 & 0.2 & 0.1 & 0.025 \\
\hline 1 & 10 & 23 & 27 & 16 & 19 & Over \\
\hline 2 & 10 & 25 & 28 & 18 & 19 & mechanical \\
\hline 3 & 12 & 22 & 26 & 17 & 21 & limit \\
\hline Avg (psi) & 10.66667 & 23.33333 & 54 & 85 & 196.6667 & \\
\hline
\end{tabular}

\section{M50BA}

\begin{tabular}{|c|r|r|r|r|r|}
\hline time & $3 \mathrm{hr}$ & $6 \mathrm{hr}$ & $12 \mathrm{hr}$ & $24 \mathrm{hr}$ & $14 \mathrm{day}$ \\
\hline Area $\left(\mathrm{in}^{2}\right)$ & 1 & 1 & 1 & 0.75 & 0.025 \\
\hline 1 & & 12 & 32 & 58 & Over \\
\hline 2 & under & 12 & 41 & 45 & mechanical \\
\hline 3 & & 14 & 37 & 52 & limit \\
\hline Avg (psi) & & 12.66667 & 36.66667 & 68.88889 & \\
\hline
\end{tabular}

M25BA
\begin{tabular}{|c|r|r|r|r|r|}
\hline time & $3 \mathrm{hr}$ & $6 \mathrm{hr}$ & $12 \mathrm{hr}$ & $24 \mathrm{hr}$ & 14 day \\
\hline Area $\left(\mathrm{in}^{2}\right)$ & 1 & 1 & 1 & 0.75 & 0.025 \\
\hline 1 & & & 14 & 23 & Over \\
\hline 2 & under & under & 10 & 16 & mechanical \\
\hline 3 & & & 11 & 25 & limit \\
\hline Avg $(\mathrm{psi})$ & & & 11.66667 & 28.44444 & \\
\hline
\end{tabular}

M10BA
\begin{tabular}{|c|r|r|r|r|r|}
\hline time & $3 \mathrm{hr}$ & $6 \mathrm{hr}$ & $12 \mathrm{hr}$ & $24 \mathrm{hr}$ & 14 day \\
\hline Area $\left(\mathrm{in}^{2}\right)$ & 1 & 1 & 1 & 0.75 & 0.025 \\
\hline 1 & & & 22 & 35 & Over \\
\hline 2 & under & under & 18 & 31 & mechanical \\
\hline 3 & & & 20 & 32 & limit \\
\hline Avg (psi) & & & 20 & 43.55556 & \\
\hline
\end{tabular}




\section{Penetration Resistance Testing}

M85RS

\begin{tabular}{|c|r|r|r|r|r|r|}
\hline time & $2 \mathrm{hr}$ & $4 \mathrm{hr}$ & $8 \mathrm{hr}$ & $12 \mathrm{hr}$ & $24 \mathrm{hr}$ & 14day \\
\hline area $\left(\mathrm{in}^{2}\right)$ & 1 & 1 & 0.75 & 0.5 & 0.2 & 0.025 \\
\hline 1 & 16 & 23 & 26 & 21 & 20 & Over \\
\hline 2 & 15 & 26 & 27 & 20 & 20 & mechanical \\
\hline 3 & 17 & 21 & 21 & 22 & 21 & limit \\
\hline avg $(\mathrm{psi})$ & 16 & 23.33333 & 32.88889 & 42 & 101.6667 & \\
\hline
\end{tabular}

\section{M80RS}

\begin{tabular}{|c|r|r|r|r|r|r|}
\hline time & $2 \mathrm{hr}$ & $4 \mathrm{hr}$ & $8 \mathrm{hr}$ & $12 \mathrm{hr}$ & $24 \mathrm{hr}$ & $14 \mathrm{day}$ \\
\hline Area $\left(\mathrm{in}^{2}\right)$ & 1 & 1 & 0.75 & 0.5 & 0.2 & 0.025 \\
\hline 1 & & 14 & 27 & 33 & 23 & Over \\
\hline 2 & under & 19 & 29 & 35 & 22 & mechanical \\
\hline 3 & & 19 & 24 & 30 & 23 & limit \\
\hline Avg (psi) & & 17.33333 & 35.55556 & 65.33333 & 113.3333 & \\
\hline
\end{tabular}

\section{M75RS}

\begin{tabular}{|c|r|r|r|r|r|r|}
\hline time & $2 \mathrm{hr}$ & $4 \mathrm{hr}$ & $8 \mathrm{hr}$ & $12 \mathrm{hr}$ & $24 \mathrm{hr}$ & $14 \mathrm{day}$ \\
\hline Area $\left(\mathrm{in}^{2}\right)$ & 1 & 1 & 1 & 0.75 & 0.25 & 0.025 \\
\hline 1 & & 9 & 22 & 21 & 24 & Over \\
\hline 2 & under & 10 & 27 & 20 & 22 & mechanical \\
\hline 3 & & 10 & 25 & 26 & 24 & limit \\
\hline Avg (psi) & & 9.666667 & 24.66667 & 29.77778 & 93.33333 & \\
\hline
\end{tabular}

\section{M50RS}

\begin{tabular}{|c|r|r|r|r|r|}
\hline time & $3 \mathrm{hr}$ & $6 \mathrm{hr}$ & $12 \mathrm{hr}$ & $24 \mathrm{hr}$ & 14 day \\
\hline Area $\left(\mathrm{in}^{2}\right)$ & 1 & 1 & 1 & 0.75 & 0.025 \\
\hline 1 & & 10 & 29 & 40 & Over \\
\hline 2 & under & 9 & 25 & 39 & mechanical \\
\hline 3 & & 10 & 25 & 38 & limit \\
\hline Avg (psi) & & 9.666667 & 26.33333 & 52 & \\
\hline
\end{tabular}

M25RS
\begin{tabular}{|c|r|r|r|r|r|}
\hline time & $3 \mathrm{hr}$ & $6 \mathrm{hr}$ & $12 \mathrm{hr}$ & $24 \mathrm{hr}$ & 14 day \\
\hline Area $\left(\mathrm{in}^{2}\right)$ & 1 & 1 & 1 & 0.75 & 0.025 \\
\hline 1 & & & 15 & 26 & Over \\
\hline 2 & under & under & 14 & 21 & mechanical \\
\hline 3 & & & 14 & 22 & limit \\
\hline Avg (psi) & & & 14.33333 & 30.66667 & \\
\hline
\end{tabular}

M10RS
\begin{tabular}{|c|r|r|r|r|r|}
\hline time & $3 \mathrm{hr}$ & $6 \mathrm{hr}$ & $12 \mathrm{hr}$ & $24 \mathrm{hr}$ & 14 day \\
\hline Area $\left(\mathrm{in}^{2}\right)$ & 1 & 1 & 1 & 0.75 & 0.025 \\
\hline 1 & & & 16 & 31 & Over \\
\hline 2 & under & under & 10 & 24 & mechanical \\
\hline 3 & & & 10 & 20 & limit \\
\hline Avg (psi) & & & 12 & 33.33333 & \\
\hline
\end{tabular}




\section{Penetration Resistance Testing}

M85FS

\begin{tabular}{|c|r|r|r|r|r|r|}
\hline time & $2 \mathrm{hr}$ & $4 \mathrm{hr}$ & $8 \mathrm{hr}$ & $12 \mathrm{hr}$ & $24 \mathrm{hr}$ & 14day \\
\hline area $\left(\mathrm{in}^{2}\right)$ & 1 & 1 & 0.75 & 0.5 & 0.2 & 0.025 \\
\hline 1 & 22 & 24 & 18 & 19 & 10 & 64 \\
\hline 2 & 20 & 30 & 20 & 20 & 11 & 84 \\
\hline 3 & 18 & 29 & 20 & 20 & 11 & 70 \\
\hline avg (psi) & 20 & 27.66667 & 25.77778 & 39.33333 & 53.33333 & 2906.667 \\
\hline
\end{tabular}

M80FS

\begin{tabular}{|c|r|r|r|r|r|r|}
\hline time & $2 \mathrm{hr}$ & $4 \mathrm{hr}$ & $8 \mathrm{hr}$ & $12 \mathrm{hr}$ & $24 \mathrm{hr}$ & 14day \\
\hline Area $\left(\mathrm{in}^{2}\right)$ & 1 & 1 & 0.75 & 0.5 & 0.2 & 0.025 \\
\hline 1 & 21 & 34 & 36 & 21 & 17 & Over \\
\hline 2 & 22 & 34 & 34 & 22 & 13 & mechanical \\
\hline 3 & 23 & 31 & 31 & 26 & 18 & limit \\
\hline Avg (psi) & 22 & 33 & 44.88889 & 46 & 80 & \\
\hline
\end{tabular}

\section{M75FS}

\begin{tabular}{|c|r|r|r|r|r|r|}
\hline time & $2 \mathrm{hr}$ & $4 \mathrm{hr}$ & $8 \mathrm{hr}$ & $12 \mathrm{hr}$ & $24 \mathrm{hr}$ & 14day \\
\hline Area $\left(\mathrm{in}^{2}\right)$ & 1 & 1 & 0.75 & 0.5 & 0.2 & 0.025 \\
\hline 1 & & 22 & 20 & 24 & 19 & Over \\
\hline 2 & under & 22 & 20 & 20 & 18 & mechanical \\
\hline 3 & & 18 & 21 & 20 & 20 & limit \\
\hline Avg (psi) & & 20.66667 & 27.11111 & 42.66667 & 95 & \\
\hline
\end{tabular}

\section{M50FS}

\begin{tabular}{|c|r|r|r|r|r|}
\hline time & $3 \mathrm{hr}$ & $6 \mathrm{hr}$ & $12 \mathrm{hr}$ & $24 \mathrm{hr}$ & 14 day \\
\hline Area $\left(\mathrm{in}^{2}\right)$ & 1 & 1 & 1 & 0.75 & 0.025 \\
\hline 1 & & 10 & 23 & 34 & Over \\
\hline 2 & under & 11 & 15 & 26 & mechanical \\
\hline 3 & & 11 & 19 & 30 & limit \\
\hline Avg (psi) & & 10.66667 & 19 & 40 & \\
\hline
\end{tabular}

M25FS
\begin{tabular}{|c|r|r|r|r|r|}
\hline time & $3 \mathrm{hr}$ & $6 \mathrm{hr}$ & $12 \mathrm{hr}$ & $24 \mathrm{hr}$ & $14 \mathrm{day}$ \\
\hline Area $\left(\mathrm{in}^{2}\right)$ & 1 & 1 & 1 & 1 & 0.025 \\
\hline 1 & & & 13 & 26 & Over \\
\hline 2 & under & under & 14 & 30 & mechanical \\
\hline 3 & & & 11 & 27 & limit \\
\hline Avg $(\mathrm{psi})$ & & & 12.66667 & 27.66667 & \\
\hline
\end{tabular}

M10FS
\begin{tabular}{|c|r|r|r|r|r|}
\hline time & $3 \mathrm{hr}$ & $6 \mathrm{hr}$ & $12 \mathrm{hr}$ & $24 \mathrm{hr}$ & 14 day \\
\hline Area $\left(\right.$ in $\left.^{2}\right)$ & 1 & 1 & 1 & 0.75 & 0.025 \\
\hline 1 & & & 17 & 26 & Over \\
\hline 2 & under & under & 14 & 20 & mechanical \\
\hline 3 & & & 14 & 19 & limit \\
\hline Avg (psi) & & & 15 & 28.88889 & \\
\hline
\end{tabular}




\section{Penetration Resistance Testing}

M90BA1C

\begin{tabular}{|c|r|r|r|r|r|}
\hline time & $3 \mathrm{hr}$ & $6 \mathrm{hr}$ & $12 \mathrm{hr}$ & $24 \mathrm{hr}$ & 14 day \\
\hline area $\left(\mathrm{in}^{2}\right)$ & 1 & 1 & 0.75 & 0.25 & 0.025 \\
\hline 1 & 19 & 39 & 34 & 32 & Over \\
\hline 2 & 15 & 30 & 44 & 38 & mechanical \\
\hline 3 & 18 & 32 & 34 & 28 & limit \\
\hline avg (psi) & 17.33333 & 33.66667 & 49.77778 & 130.6667 & \\
\hline
\end{tabular}

M83BA1C

\begin{tabular}{|c|r|r|r|r|r|}
\hline time & $3 \mathrm{hr}$ & $6 \mathrm{hr}$ & $12 \mathrm{hr}$ & $24 \mathrm{hr}$ & 14 day \\
\hline area $\left(\mathrm{in}^{2}\right)$ & 1 & 1 & 0.75 & 0.25 & 0.025 \\
\hline 1 & 17 & 29 & 30 & 30 & Over \\
\hline 2 & 14 & 30 & 26 & 33 & mechanical \\
\hline 3 & 14 & 36 & 30 & 24 & limit \\
\hline avg (psi) & 15 & 31.66667 & 38.22222 & 116 & \\
\hline
\end{tabular}

M75BA1C

\begin{tabular}{|c|r|r|r|r|r|}
\hline time & $3 \mathrm{hr}$ & $6 \mathrm{hr}$ & $12 \mathrm{hr}$ & $24 \mathrm{hr}$ & 14 day \\
\hline area $\left(\mathrm{in}^{2}\right)$ & 1 & 1 & 0.75 & 0.25 & 0.025 \\
\hline 1 & 11 & 34 & 40 & 44 & Over \\
\hline 2 & 10 & 30 & 26 & 44 & mechanical \\
\hline 3 & 11 & 29 & 24 & 38 & limit \\
\hline avg (psi) & 10.66667 & 31 & 40 & 168 & \\
\hline
\end{tabular}

M85RS1C

\begin{tabular}{|c|r|r|r|r|r|}
\hline time & $3 \mathrm{hr}$ & $6 \mathrm{hr}$ & $12 \mathrm{hr}$ & $24 \mathrm{hr}$ & 14 day \\
\hline area $\left(\mathrm{in}^{2}\right)$ & 1 & 1 & 0.75 & 0.2 & 0.025 \\
\hline 1 & 12 & 30 & 37 & 61 & Over \\
\hline 2 & 8 & 28 & 38 & 19 & mechanical \\
\hline 3 & 8 & 26 & 40 & 22 & limit \\
\hline avg (psi) & 9.333333 & 28 & 51.11111 & 170 & \\
\hline
\end{tabular}

M80RS1C

\begin{tabular}{|c|r|r|r|r|r|}
\hline time & $3 \mathrm{hr}$ & $6 \mathrm{hr}$ & $12 \mathrm{hr}$ & $24 \mathrm{hr}$ & $14 \mathrm{day}$ \\
\hline area $\left(\mathrm{in}^{2}\right)$ & 1 & 1 & 0.75 & 0.2 & 0.025 \\
\hline 1 & 12 & 31 & 45 & 34 & Over \\
\hline 2 & 8 & 29 & 36 & 36 & mechanical \\
\hline 3 & 10 & 29 & 44 & 27 & limit \\
\hline avg (psi) & 10 & 29.66667 & 55.55556 & 161.6667 & \\
\hline
\end{tabular}

M75RS1C
\begin{tabular}{|c|r|r|r|r|r|}
\hline time & $3 \mathrm{hr}$ & $6 \mathrm{hr}$ & $12 \mathrm{hr}$ & $24 \mathrm{hr}$ & 14 day \\
\hline area $\left(\mathrm{in}^{2}\right)$ & 1 & 1 & 0.75 & 0.2 & 0.025 \\
\hline 1 & & 20 & 30 & 28 & Over \\
\hline 2 & under & 16 & 32 & 24 & mechanical \\
\hline 3 & & 20 & 34 & 28 & limit \\
\hline avg (psi) & & 18.66667 & 42.66667 & 133.3333 & \\
\hline
\end{tabular}




\section{Penetration Resistance Testing}

M85FS1C

\begin{tabular}{|c|r|r|r|r|r|}
\hline time & $3 \mathrm{hr}$ & $6 \mathrm{hr}$ & $12 \mathrm{hr}$ & $24 \mathrm{hr}$ & 14 day \\
\hline area $\left(\mathrm{in}^{2}\right)$ & 1 & 1 & 1 & 0.75 & 0.025 \\
\hline 1 & 14 & 15 & 22 & 12 & Over \\
\hline 2 & 11 & 15 & 21 & 14 & mechanical \\
\hline 3 & 11 & 16 & 20 & 18 & limit \\
\hline avg (psi) & 12 & 15.33333 & 21 & 19.55556 & \\
\hline
\end{tabular}

M80FS1C

\begin{tabular}{|c|r|r|r|r|r|}
\hline time & $3 \mathrm{hr}$ & $6 \mathrm{hr}$ & $12 \mathrm{hr}$ & $24 \mathrm{hr}$ & 14 day \\
\hline area $\left(\mathrm{in}^{2}\right)$ & 1 & 1 & 1 & 0.75 & 0.025 \\
\hline 1 & & 14 & 18 & 25 & Over \\
\hline 2 & under & 14 & 18 & 22 & mechanical \\
\hline 3 & & 13 & 19 & 30 & limit \\
\hline avg (psi) & & 13.66667 & 18.33333 & 34.22222 & \\
\hline
\end{tabular}

M75FS1C

\begin{tabular}{|c|r|r|r|r|r|}
\hline time & $3 \mathrm{hr}$ & $6 \mathrm{hr}$ & $12 \mathrm{hr}$ & $24 \mathrm{hr}$ & 14 day \\
\hline area $\left(\mathrm{in}^{2}\right)$ & 1 & 1 & 1 & 0.75 & 0.025 \\
\hline 1 & & 10 & 20 & 22 & 120 \\
\hline 2 & under & 10 & 18 & 19 & 120 \\
\hline 3 & & 11 & 14 & 22 & 110 \\
\hline avg (psi) & & 10.33333 & 17.33333 & 28 & 4666.667 \\
\hline
\end{tabular}




\section{Appendix C \\ Data Collected From Pipe Testing}




\section{Collected data for 6 inch Pipes}

\section{High strength In-Situ Soil with High Strength CLSM}

9 inch trench

\begin{tabular}{|c|c|c|c|c|c|c|c|}
\hline pressure & Opsi & 2 & 5 & 10 & 15 & 20 & 24hour \\
\hline deflection 1 & $\begin{array}{l}0.28 \\
\end{array}$ & 0.28 & 0.28 & 0.28 & 0.28 & 0.15 & 0.19 \\
\hline deflection 2 & 0.283 & 0.283 & 0.283 & 0.267 & 0.21 & 0.75 & 0.218 \\
\hline deflection 3 & 0.26 & 0.26 & 0.26 & 0.26 & 0.27 & 0.15 & 0.15 \\
\hline center stress & 1.49 & 1.86 & 5.54 & 15.52 & 23.72 & 30.81 & 1.77 \\
\hline center stress & 0.94 & 2.15 & 6.68 & 19.26 & 28.68 & 35.42 & 3.73 \\
\hline in-situ soil & 1.28 & 2.28 & 4.8 & 11.76 & 18.03 & 24.63 & 1.37 \\
\hline \multicolumn{8}{|l|}{ Summary } \\
\hline pressure & Opsi & 2 & 5 & 10 & 15 & 20 & 24hour \\
\hline $\max d$ & 0 & 0 & 0 & 0.0016 & 0.0073 & 0.0208 & 0.011 \\
\hline avg. $p$ & 1.215 & 2.005 & 6.11 & 17.39 & 26.2 & 33.115 & 2.75 \\
\hline \multicolumn{8}{|c|}{12 inch trench } \\
\hline pressure & Opsi & 5 & 10 & 15 & 20 & 25 & 30 24 hour \\
\hline deflection 1 & $\begin{array}{l}0.284 \\
\end{array}$ & 0.284 & 0.325 & 0.558 & 0.762 & 0.955 & \begin{tabular}{l|l} 
& 0.955 \\
\end{tabular} \\
\hline deflection 2 & 0.401 & 0.401 & 0.156 & 0.085 & -0.289 & -0.48 & -0.232 \\
\hline deflection 3 & 0.3 & 0.3 & 0.3 & 0.5 & 0.21 & 0.39 & 0.31 \\
\hline center stress & 1.81 & 4.1 & 7.87 & 11.28 & 13.93 & 15.71 & 4.22 \\
\hline center stress & 1.42 & 8.05 & 18.42 & 27 & 35.52 & 37.1 & 4.89 \\
\hline in-situ soil & 0.43 & 4.57 & 8.28 & 12.21 & 16.06 & 20.04 & 1.09 \\
\hline \multicolumn{8}{|l|}{ Summary } \\
\hline pressure & Opsi & 5 & 10 & 15 & 20 & 25 & 24 hour \\
\hline $\operatorname{axd}$ & 0 & 0 & 0.0245 & 0.0486 & 0.069 & 0.0881 & \begin{tabular}{|l}
0.0633 \\
\end{tabular} \\
\hline & 1.615 & 6.075 & 13.145 & 19.14 & 24.725 & 26.405 & 4.55 \\
\hline
\end{tabular}

\section{5 inch trench}

\begin{tabular}{|l|l|r|r|r|r|r|r|r|r|}
\hline pressure & Opsi & 5 & 10 & 15 & 20 & 25 & 30 & 24 hour \\
\hline deflection 1 & $\#$ & & $\#$ & $\#$ & $\#$ & $\#$ & $\#$ & $\#$ & $\#$ \\
\hline deflection 2 & 0.784 & 0.749 & 0.713 & 0.522 & 0.414 & 0.305 & 0.21 & 0.388 \\
\hline deflection 3 & 0.01 & 0.01 & 0 & 0 & -0.09 & -0.21 & -0.31 & 0.3 \\
\hline center stress & 2.65 & 2.51 & 9.88 & 17.29 & 23.17 & 28.25 & 32.02 & 8.2 \\
\hline center stress & 1.52 & 1.42 & 9.31 & 14.68 & 18.57 & 22.36 & 25.42 & 7.11 \\
\hline in-situ soil & 0.45 & 3.47 & 7.45 & 11.25 & 15.28 & 19.67 & 24.25 & 1.31 \\
\hline
\end{tabular}

Summary

\begin{tabular}{|l|r|r|r|r|r|r|r|r|}
\hline pressure & Opsi & 5 & 10 & 15 & 20 & 25 & 30 & 24 hour \\
\hline max d & 0 & 0.0035 & 0.0071 & 0.0262 & 0.037 & 0.0479 & 0.0574 & 0.0446 \\
\hline avg. p & 2.085 & 1.965 & 9.595 & 15.985 & 20.87 & 25.305 & 28.72 & 7.655 \\
\hline
\end{tabular}

\section{8 inch trench}

\begin{tabular}{|l|r|r|r|r|r|r|r|r|}
\hline pressure & Opsi & 5 & 10 & 15 & 20 & 25 & 30 & 24 hour \\
\hline deflection 1 & 0.315 & 0.315 & 0.315 & 0.315 & 0.315 & 0.315 & 0.315 & 0.335 \\
\hline deflection 2 & 0.624 & 0.624 & 0.575 & 0.475 & 0.38 & 0.29 & 0.22 & 0.222 \\
\hline deflection 3 & 0.33 & 0.33 & 0.33 & 0.33 & 0.29 & 0.2 & 0.12 & 0.12 \\
\hline center stress & 2.14 & 2.65 & 6.8 & 12.3 & 17.85 & 22.56 & 26.85 & -2.66 \\
\hline center stress & 0.47 & 1 & 6.47 & 10.89 & 14.21 & 16.89 & 19.21 & 5.47 \\
\hline in-situ soil & 0 & 1.6 & 4.39 & 7 & 9.79 & 12.49 & 15.19 & 0.45 \\
\hline Summary & \multicolumn{7}{|c|}{} \\
\hline pressure & 0psi & 5 & 10 & 15 & 20 & 25 & 30 & $24 \mathrm{hour}$ \\
\hline max d & 0 & 0 & 0.0049 & 0.0149 & 0.0244 & 0.0334 & 0.0404 & 0.0402 \\
\hline avg. p & 1.305 & 1.825 & 6.635 & 11.595 & 16.03 & 19.725 & 23.03 & 1.405 \\
\hline
\end{tabular}




\section{Collected Data for 6 inch Pipes}

\section{High Strength In-Situ Soil with Low Strength CLSM}

\section{9 inch trench}

\begin{tabular}{|l|r|r|r|r|r|r|r|r|}
\hline pressure & 0psi & 5 & 10 & 15 & 20 & 25 & 30 & $24 \mathrm{hour}$ \\
\hline deflection 1 & 0.0121 & 0.0355 & 0.1138 & 0.1757 & 0.238 & 0.2855 & 0.3365 & 0.2855 \\
\hline deflection 2 & -0.0242 & -0.0483 & -0.1194 & -0.179 & 0.2421 & -0.2909 & -0.345 & -0.2892 \\
\hline deflection 3 & -0.003 & 0.008 & 0.057 & 0.109 & 0.166 & 0.213 & 0.264 & 0.205 \\
\hline center stress & \#\# & & & & & & & \\
\hline center stress & 1.21 & 7.52 & 14.63 & 18.52 & 21.78 & 24.78 & 28.36 & 5.36 \\
\hline in-situ soil & 0.22 & 3.61 & 7.41 & 10.93 & 14.82 & 18.12 & 22.1 & 2.05 \\
\hline Summary & \multicolumn{7}{|l|}{} \\
\hline pressure & $0 p s i$ & 5 & 10 & 15 & 20 & 25 & 30 & $24 \mathrm{hour}$ \\
\hline max d & 0 & 0.024 & 0.1017 & 0.1636 & 0.2259 & 0.2734 & 0.3244 & 0.265 \\
\hline avg. p & 1.21 & 7.52 & 14.63 & 18.52 & 21.78 & 24.78 & 28.36 & 5.36 \\
\hline
\end{tabular}

\section{2 inch trench}

\begin{tabular}{|c|c|c|c|c|c|c|c|c|}
\hline resst & Opsi & 5 & 10 & 15 & 20 & 25 & \multicolumn{2}{|c|}{ 30 24 hour } \\
\hline lefle & -0.0121 & 0.0081 & 0.0579 & 0.0945 & 0.1402 & 0.1778 & 0.2205 & 0.1646 \\
\hline defle & 0.0032 & -0.0184 & -0.065 & -0.102 & -0.1485 & -0.1871 & -0.2331 & -0.1825 \\
\hline defle & -0.004 & -0.004 & 0.028 & 0.06 & 0.103 & 1441 & 0.184 & 0.156 \\
\hline cente & 1.95 & 3.77 & 6.29 & 8.81 & 11.32 & 13.7 & 16.27 & 3.03 \\
\hline tress & 1.84 & \begin{tabular}{|l|}
7.84 \\
\end{tabular} & 14.15 & 18.57 & 21 & 23.84 & 26.15 & 6.89 \\
\hline -situ soil & \#\# & \#\# & 8.32 & 10.93 & 14 & 16.84 & 20.41 & 2.24 \\
\hline \multicolumn{9}{|l|}{ Summary } \\
\hline & Opsi & 5 & 10 & 15 & 20 & 25 & 30 & 24hour \\
\hline nax d & 0 & 0.0216 & 0.07 & 0.1066 & 0.1523 & 0.1903 & 0.2362 & 0.1857 \\
\hline vg. p & 1.895 & 5.805 & 10.22 & 13.69 & 16.16 & 18.77 & 21.21 & 4.96 \\
\hline
\end{tabular}

\section{5 inch trench}

\begin{tabular}{|l|r|r|r|r|r|r|r|r|}
\hline pressure & Opsi & 5 & 10 & 15 & 20 & 25 & 30 & 24hour \\
\hline deflection 1 & 0.0274 & 0.0034 & 0.068 & 0.0975 & 0.1219 & 0.1464 & 0.1646 & 0.1402 \\
\hline deflection 2 & -0.0154 & -0.0294 & -0.0627 & -0.0903 & -0.1121 & -0.1339 & -0.1506 & -0.1135 \\
\hline deflection 3 & 0.029 & 0.032 & 0.065 & 0.097 & 0.123 & 0.149 & 0.17 & 0.139 \\
\hline center stress & 2.47 & 7.55 & 16.41 & 22.7 & 27.17 & 30.45 & 33.24 & 7.27 \\
\hline center stress & 1.15 & 6.63 & 18.15 & 28.63 & 36.57 & 43.26 & 48.63 & 8.36 \\
\hline in-situ soil & 1.46 & 5.53 & 10.11 & 15.33 & $\# \#$ & & & \\
\hline Summary & \multicolumn{7}{|c|}{} \\
\hline pressure & 0psi & 5 & 10 & 15 & 20 & 25 & 30 & $24 \mathrm{hour}$ \\
\hline max d & 0 & 0.014 & 0.0473 & 0.0749 & 0.0967 & 0.12 & 0.141 & 0.1128 \\
\hline avg. p & 1.81 & 7.09 & 17.28 & 25.665 & 31.87 & 36.855 & 40.935 & 7.815 \\
\hline
\end{tabular}

\section{8 inch trench}

\begin{tabular}{|l|r|r|r|r|r|r|r|r|}
\hline pressure & Opsi & 5 & 10 & 15 & 20 & 25 & 30 & 24 hour \\
\hline deflection 1 & 0 & 0.0162 & 0.0487 & 0.0944 & 0.1504 & 0.2042 & 0.2631 & 0.2083 \\
\hline deflection 2 & 0.0132 & -0.0177 & -0.0508 & -0.0975 & -0.1538 & -0.209 & -0.2669 & -0.1269 \\
\hline deflection 3 & 0.043 & 0.07 & 0.101 & 0.147 & 0.203 & 0.256 & 0.312 & 0.224 \\
\hline center stress & 1.77 & 6.57 & 10.3 & 13.98 & 18.08 & 21.25 & 24.75 & 3.96 \\
\hline center stress & 0.89 & 7.52 & 11.84 & 15.31 & 19.15 & 21.89 & 24.94 & 4.15 \\
\hline in-situ soil & 0.68 & 3.52 & 6.59 & 10.61 & 15.14 & 20.54 & 25.3 & 0.73 \\
\hline Summary & \multicolumn{7}{|c|}{} \\
\hline pressure & Opsi & 5 & 10 & 15 & 20 & 25 & 30 & 24 hour \\
\hline max d & 0 & 0.0309 & 0.064 & 0.1107 & 0.167 & 0.2222 & 0.2801 & 0.2083 \\
\hline avg. p & 1.33 & 7.045 & 11.07 & 14.645 & 18.615 & 21.57 & 24.845 & 4.055 \\
\hline
\end{tabular}


Collected Data for 6 inch Pipes

Low Strength In-Situ Soil with High Strength CLSM

9 inch trench

\begin{tabular}{|c|c|c|c|c|c|c|c|c|}
\hline pressure & Opsi & 5 & 10 & 15 & 20 & 25 & \multicolumn{2}{|c|}{\begin{tabular}{l|l|}
30 & 24 hour \\
\end{tabular}} \\
\hline deflection 1 & -0.0445 & -0.052 & -0.069 & -0.092 & -0.1094 & -0.1265 & -0.1465 & -0.1281 \\
\hline deflection 2 & -0.064 & -0.0673 & -0.0812 & -0.1073 & -0.1238 & -0.1391 & -0.1539 & -0.1494 \\
\hline deflection 3 & 0.078 & 0.083 & 0.086 & 0.119 & 0.136 & 0.159 & 0.175 & 0.159 \\
\hline center stress & -3.64 & 6.85 & 13.75 & 19.11 & 22.93 & 26.8 & 31.51 & 7.1 \\
\hline center stress & -1.58 & 7.57 & 18.42 & 25.21 & 30.41 & 36.68 & 41.63 & 3.66 \\
\hline in-situ soil & -0.05 & 3.02 & 6.95 & 10.38 & 13.68 & 16.33 & 20.59 & 1.09 \\
\hline \multicolumn{9}{|l|}{ Summary } \\
\hline pressure & Opsi & 5 & 10 & 15 & 20 & 25 & 30 & 24hour \\
\hline $\max d$ & & & 0.0245 & & 0.0649 & & 0.102 & \\
\hline avg. $p$ & & & 16.085 & & 26.67 & & 36.57 & \\
\hline
\end{tabular}

12 inch trench

\begin{tabular}{|l|r|r|r|r|r|r|r|r|}
\hline pressure & Opsi & 5 & 10 & 15 & 20 & 25 & 30 & 24 hour \\
\hline deflection 1 & 0.0749 & 0.0783 & 0.0943 & 0.1032 & 0.1126 & 0.1249 & 0.1315 & 0.1154 \\
\hline deflection 2 & 0.0425 & 0.0449 & 0.0604 & 0.0691 & 0.0775 & 0.0877 & 0.0933 & 0.0814 \\
\hline deflection 3 & 0.083 & 0.083 & 0.093 & 0.104 & 0.113 & 0.125 & 0.131 & 0.13 \\
\hline center stress & 1.72 & 5.54 & 14.07 & 19.62 & 24.94 & 29.88 & 33.14 & 6.99 \\
\hline center stress & -2 & 1.1 & 8 & 12.01 & 16.05 & 19.31 & 22.05 & 1.84 \\
\hline in-situ soil & 0.73 & 5.35 & 9.61 & 14.64 & 19.49 & 25.26 & 29.97 & 0.86 \\
\hline Summary & \multicolumn{7}{|l|}{} \\
\hline pressure & Opsi & 5 & 10 & 15 & 20 & 25 & & 24 hour \\
\hline max d & & & 0.0194 & & 0.0377 & & 0.0566 & \\
\hline avg. p & & & 11.04 & & 20.5 & & 27.6 & \\
\hline
\end{tabular}

\section{5 inch trench}

\begin{tabular}{|l|r|r|r|r|r|r|r|r|}
\hline pressure & Opsi & 5 & 10 & 15 & 20 & 25 & 30 & 24 hour \\
\hline deflection 1 & -0.0281 & -0.02 & 0.0029 & 0.0127 & 0.0245 & 0.0344 & 0.0418 & 0.0348 \\
\hline deflection 2 & 0.037 & 0.0435 & 0.0576 & 0.0641 & 0.0717 & 0.0793 & 0.086 & 0.0773 \\
\hline deflection 3 & -0.038 & -0.038 & -0.023 & -0.007 & 0.006 & 0.018 & 0.028 & 0.028 \\
\hline center stress & 1.07 & 4.42 & 8.01 & 11 & 13.33 & 15.29 & 17.15 & 5.54 \\
\hline center stress & -1.79 & 2.63 & 8.94 & 15.57 & 20.05 & 24 & 27.15 & 5.68 \\
\hline in-situ soil & 0.5 & 3.66 & 6.59 & 10.16 & 13.77 & 17.43 & 20.96 & 0.86 \\
\hline Summary & \multicolumn{7}{|l|}{} \\
\hline pressure & 0psi & 5 & 10 & 15 & 20 & 25 & 30 & $24 \mathrm{hour}$ \\
\hline max d & & & 0.031 & & 0.0527 & & 0.0699 & \\
\hline avg.p & & & 8.43 & & 16.91 & & 24.06 & \\
\hline
\end{tabular}




\section{Collected Data for 6 inch Pipes}

Low Strength In-Situ Soil with Low Strength CLSM

9 inch trench

\begin{tabular}{|c|c|c|c|c|c|c|c|c|}
\hline pressure & Opsi & 5 & 10 & 15 & 20 & 25 & & 24hour \\
\hline deflection 1 & 0.0345 & 0.1574 & 0.2743 & 0.3648 & 0.4369 & 0.4938 & 0.5517 & 0.4126 \\
\hline deflection 2 & -0.0514 & -0.1708 & -0.2872 & -0.3747 & -0.4435 & -0.4991 & -0.5561 & -0.3666 \\
\hline deflection 3 & 0.041 & 0.152 & 0.261 & 0.344 & 0.407 & 0.459 & 0.512 & 0.366 \\
\hline center stress & 2.61 & 8.53 & 11.79 & 15.19 & 17.94 & 20.32 & 22.84 & 4.94 \\
\hline center stress & -0.32 & 5.63 & 8.31 & 11.47 & 13.89 & 15.94 & 18.15 & 1.63 \\
\hline in-situ soil & \# & \# & \# & $\#$ & \# & $\#$ & \# & \# \\
\hline \multicolumn{9}{|l|}{ Summary } \\
\hline pressure & Opsi & 5 & 10 & 15 & 20 & 25 & & 24hour \\
\hline $\max d$ & & & 0.2398 & & 0.4024 & & 0.5172 & \\
\hline avg. $p$ & & & 10.05 & & 15.915 & & 20.495 & \\
\hline \multicolumn{9}{|c|}{12 inch trench } \\
\hline pressure & Opsi & 5 & 10 & 15 & 20 & 25 & & 24 hour \\
\hline deflection 1 & \begin{tabular}{|l|}
-0.0365 \\
\end{tabular} & -0.006 & & 0.1717 & 0.2601 & 0.3231 & 0.3882 & 0.2459 \\
\hline deflection 2 & -0.135 & -0.0967 & & 0.0758 & 0.1621 & 0.2199 & 0.2799 & 0.1098 \\
\hline deflection 3 & -0.0932 & -0.0885 & & -0.0696 & -0.0605 & -0.0546 & -0.0485 & -0.0638 \\
\hline center stress & 2.33 & 9.04 & 13.61 & 17.01 & 20.37 & 23.31 & 26.94 & 3.44 \\
\hline center stress & -0.16 & 5.73 & 9.68 & 12.94 & 16.21 & 19.05 & 22.63 & 0.47 \\
\hline in-situ soil & 0.27 & 4.94 & 10.61 & 16.38 & 22.83 & 27.78 & 33.86 & 0.59 \\
\hline \multicolumn{9}{|l|}{ Summary } \\
\hline pressure & Opsi & 5 & 10 & 15 & 20 & 25 & 30 & 24hour \\
\hline $\operatorname{maxd}$ & & & & & 0.2966 & & 0.4247 & \\
\hline avg.p & & & 11.645 & & 18.29 & & 24.785 & \\
\hline \multicolumn{9}{|c|}{15 inch trench } \\
\hline pressure & Opsi & 5 & 10 & 15 & 20 & 25 & & 24 hour \\
\hline deflection 1 & 0.0243 & 0.904 & 0.189 & 0.2814 & |0.3597 & 0.4408 & 0.5151 & 0.4095 \\
\hline deflec & 0.0403 & 0.0287 & 0.1285 & 0.2215 & 0.3011 & 0.3827 & 0.4552 & 0.2115 \\
\hline deflection 3 & -0.0879 & -0.0815 & -0.0714 & -0.0623 & -0.0546 & -0.0496 & -0.0396 & -0.0607 \\
\hline center stress & 2.61 & 7.27 & 10.81 & $\begin{array}{l}14.07 \\
\end{array}$ & 17.48 & 20.51 & 23.58 & 4.14 \\
\hline center stress & 0 & 4.31 & 7.05 & 9.63 & 12.42 & 14.89 & 17.31 & 1.57 \\
\hline in-situ soil & 0.36 & 4.53 & 9.88 & 15.24 & 21 & 26.72 & 32.99 & 0.68 \\
\hline \multicolumn{9}{|l|}{ Summary } \\
\hline pressure & Opsi & 5 & 10 & 15 & 20 & 25 & 30 & 24hour \\
\hline $\max d$ & & & 0.1647 & & 0.3354 & & 0.4908 & \\
\hline avg. $p$ & & & 8.93 & & 14.95 & & 20.445 & \\
\hline
\end{tabular}




\section{Collected data for 8 inch Pipes}

\section{High strength In-Situ Soil with High Strength CLSM}

12 inch trench

\begin{tabular}{|c|c|c|c|c|c|c|c|c|}
\hline pressure & Opsi & 5 & 10 & 15 & 20 & 25 & & 24hour \\
\hline deflection 1 & 0.3848 & 0.2336 & 0.2127 & 0.1051 & 0.0247 & -0.0282 & -0.0907 & -0.0161 \\
\hline deflection 2 & 0.0966 & 0.0323 & -0.0789 & -0.1824 & -0.265 & -0.3186 & -0.3825 & -0.3107 \\
\hline deflection 3 & -0.0688 & -0.0003 & 0.112 & 0.2191 & 0.3008 & 0.3526 & 0.4132 & 3577 \\
\hline center stress & 2.19 & 8.48 & 15.61 & 20.18 & 24 & 26.38 & 30.06 & 6.99 \\
\hline center stress & 0 & 7.31 & 15.71 & 20.26 & 23.57 & 25.52 & 28.73 & .42 \\
\hline in-situ soil & 0.27 & 4.02 & 9.47 & 15.24 & 21.09 & 25.4 & 31.94 & 0.73 \\
\hline \multicolumn{9}{|l|}{ Summary } \\
\hline pressure & Opsi & 5 & 10 & 15 & 20 & 25 & \multicolumn{2}{|c|}{\begin{tabular}{l|l|}
30 & 24 hour \\
\end{tabular}} \\
\hline $\operatorname{maxd}$ & & & 0.1808 & & 0.3696 & & 0.482 & \\
\hline avg. $p$ & & & 15.66 & & 23.785 & & 29.395 & \\
\hline \multicolumn{9}{|c|}{16 inch trench } \\
\hline pressure & Opsi & 5 & 10 & 15 & 20 & 25 & \multicolumn{2}{|c|}{\begin{tabular}{l|l|}
30 & 24 hour \\
\end{tabular}} \\
\hline deflection 1 & 0.3411 & 0.3373 & 0.3088 & 0.2775 & 0.2438 & 0.2165 & 0.187 & 0.2141 \\
\hline deflection 2 & -0.1258 & -0.1258 & -0.1064 & -0.078 & -0.0435 & -0.0148 & 0.015 & 0.0052 \\
\hline deflecti & -0.0921 & -0.904 & -0.0625 & -0.0297 & -0.0065 & 0.0368 & 0.0699 & 0.0362 \\
\hline center stress & 2.05 & 3.77 & 7.41 & 9.69 & 10.91 & 11.98 & 13.42 & 3.77 \\
\hline center stress & -1 & 1.36 & 8.49 & 14.73 & 18.42 & 21.78 & 25.78 & 3.94 \\
\hline in-situ soil & 0.41 & 3.43 & 7.09 & 10.98 & 16.06 & 20.86 & 27.76 & 0.45 \\
\hline \multicolumn{9}{|l|}{ Summary } \\
\hline pressure & Opsi & 5 & 10 & 15 & 20 & 25 & \multicolumn{2}{|c|}{ 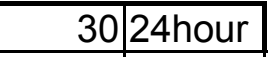 } \\
\hline $\operatorname{maxd}$ & & & 0.0323 & & 0.0973 & & 0.162 & \\
\hline avg. $p$ & & & 7.95 & & 14.665 & & 19.6 & \\
\hline \multicolumn{9}{|c|}{20 inch trench } \\
\hline pressure & Opsi & 5 & 10 & 15 & 20 & 25 & \multicolumn{2}{|c|}{\begin{tabular}{r|l|}
30 & 24 hour \\
\end{tabular}} \\
\hline deflection 1 & 0.0131 & 0.0131 & 0.0032 & -0.0105 & -0.0323 & -0.0476 & -0.0625 & -0.0472 \\
\hline deflecti & 0.0384 & 0.0384 & 0.0384 & 0.0301 & 0.0096 & -0.0057 & -0.0204 & -0.0074 \\
\hline deflection 3 & -0.012 & -0.012 & -0.012 & -0.006 & 0.017 & 0.033 & 0.05 & 0.048 \\
\hline center stress & 1.44 & 2.51 & 6.24 & 9.04 & 10.67 & 11.98 & 12.86 & 3.54 \\
\hline center stress & $\mid-1.64$ & -0.69 & 2.84 & 5.05 & 6.42 & 7.31 & 8.36 & 0.57 \\
\hline in-situ soil & 0.41 & 3.11 & 6.04 & 9.19 & 13.54 & 16.29 & 19.54 & 0.18 \\
\hline \multicolumn{9}{|l|}{ Summary } \\
\hline pressure & Opsi & 5 & 10 & 15 & 20 & 25 & \multicolumn{2}{|c|}{3024 hour } \\
\hline $\max d$ & & & 0.0099 & & 0.0454 & & 0.0856 & \\
\hline avg. $p$ & & & 4.54 & & 8.545 & & 10.61 & \\
\hline
\end{tabular}


Collected Data for 8 inch Pipes

High Strength In-Situ Soil with Low Strength CLSM

12 inch trench

\begin{tabular}{|c|c|c|c|c|c|c|c|}
\hline pressure & Opsi & 5 & 10 & 15 & 20 & 25 & \begin{tabular}{l|l}
30 & 24 hour \\
\end{tabular} \\
\hline deflection 1 & 0.0426 & 0.2073 & 0.4639 & 0.627 & 0.7316 & 0.8282 & \begin{tabular}{l|l} 
& 0.4969 \\
\end{tabular} \\
\hline deflection 2 & -0.0614 & -0.2435 & -0.4843 & -0.6785 & -0.785 & -0.8312 & -0.5257 \\
\hline deflection 3 & 0.038 & 0.215 & $\begin{array}{l}0.457 \\
\end{array}$ & 0.656 & 0.765 & 0.866 & 0.52 \\
\hline center stress & 1.91 & 6.89 & 9.93 & 11.84 & 13.65 & 15.91 & 4.7 \\
\hline center stress & 0.31 & 6.68 & 11.63 & 15.52 & 18.89 & 22.47 & 3.21 \\
\hline in-situ soil & 0.66 & 4.34 & 6.4 & 11.25 & 15.78 & 20.64 & 0.13 \\
\hline \multicolumn{8}{|l|}{ Summary } \\
\hline pressure & Opsi & 5 & 10 & 15 & 20 & 25 & \begin{tabular}{l|l|}
30 & 24 hour \\
\end{tabular} \\
\hline $\max d$ & 0 & 0.1821 & 0.4229 & 0.618 & 0.727 & 0.828 & \begin{tabular}{l|l} 
& 0.482 \\
\end{tabular} \\
\hline avg. $p$ & 1.11 & 6.785 & 10.78 & 13.68 & 16.27 & 19.19 & 3.955 \\
\hline
\end{tabular}

16 inch trench

\begin{tabular}{|l|l|r|r|r|r|r|r|r|}
\hline pressure & Opsi & 5 & 10 & 15 & 20 & 25 & 30 & $24 \mathrm{hour}$ \\
\hline deflection 1 & -0.0264 & -0.0159 & 0.0254 & 0.0558 & 0.0975 & 0.128 & 0.1646 & 0.1178 \\
\hline deflection 2 & -0.0123 & -0.0359 & -0.087 & -0.1199 & -0.1633 & -0.1935 & -0.2291 & -0.171 \\
\hline deflection 3 & 0.005 & 0.005 & 0.009 & 0.027 & 0.07 & 0.101 & 0.137 & 0.097 \\
\hline center stress & 2.65 & 11.14 & 18 & 21.07 & 22.33 & 24.38 & 26.06 & 8.2 \\
\hline center stress & 0 & 4.94 & 10.84 & 14.73 & 17.31 & 29.15 & 22.63 & 5.21 \\
\hline in-situ soil & 1.09 & 2.79 & 6.68 & 10.2 & 14.32 & 18.62 & 23.43 & -0.14 \\
\hline Summary & \multicolumn{7}{|c|}{} \\
\hline pressure & Opsi & 5 & 10 & 15 & 20 & 25 & 30 & $24 \mathrm{hour}$ \\
\hline max d & 0 & 0.0236 & 0.0747 & 0.1076 & 0.151 & 0.1812 & 0.2168 & 0.1587 \\
\hline avg. p & 1.325 & 8.04 & 14.42 & 17.9 & 19.82 & 26.765 & 24.345 & 6.705 \\
\hline
\end{tabular}

20 inch trench

\begin{tabular}{|l|l|r|r|r|r|r|r|r|}
\hline pressure & Opsi & 5 & 10 & 15 & 20 & 25 & 30 & 24 hour \\
\hline deflection 1 & -0.0782 & -0.0701 & -0.0345 & 0.0091 & 0.0528 & 0.0955 & 0.1493 & 0.065 \\
\hline deflection 2 & -0.0108 & -0.0314 & -0.0668 & -0.1036 & -0.1403 & -0.1765 & -0.2219 & -0.1296 \\
\hline deflection 3 & 0.006 & 0.006 & 0.006 & 0.006 & 0.038 & 0.074 & 0.119 & 0.119 \\
\hline center stress & 2.19 & 6.1 & 11.32 & 15.01 & 18.22 & 21.58 & 23.63 & 5.68 \\
\hline center stress & 0.31 & 4.47 & 9.1 & 11.47 & 13.73 & 16.31 & 18.15 & 4.54 \\
\hline in-situ soil & 1.83 & 3.43 & 5.4 & 7.91 & 10.7 & 14.18 & 18.16 & 0.36 \\
\hline Summary & \multicolumn{7}{|c|}{} \\
\hline pressure & 0psi & 5 & 10 & 15 & 20 & 25 & 30 & $24 \mathrm{hour}$ \\
\hline max d & 0 & 0.0206 & 0.056 & 0.0928 & 0.131 & 0.1737 & 0.2275 & 0.1432 \\
\hline avg.p & 1.25 & 5.285 & 10.21 & 13.24 & 15.975 & 18.945 & 20.89 & 5.11 \\
\hline
\end{tabular}




\section{Collected Data for 8 inch Pipes}

\section{Low Strength In-Situ Soil with High Strength CLSM}

12 inch trench

\begin{tabular}{|c|c|c|c|c|c|c|c|c|}
\hline pressure & Opsi & 5 & 10 & 15 & 20 & 25 & & 24 hour \\
\hline deflection 1 & $\#$ & \# & \# & \# & \# & -0.024 & -0.05 & -0.041 \\
\hline deflection 2 & -0.0149 & -0.0149 & -0.0149 & -0.0448 & \begin{tabular}{|l|}
-0.0874 \\
\end{tabular} & -0.1217 & -0.1476 & -0.1477 \\
\hline deflection 3 & 0.01 & 0.01 & \begin{tabular}{|l|}
0.039 \\
\end{tabular} & 0.085 & 0.137 & & $\#$ & \# \\
\hline cente & 1.86 & 6.43 & 12.58 & 17.29 & 20.83 & 23.44 & \begin{tabular}{|l}
27.27 \\
\end{tabular} & 4.05 \\
\hline center & -1.9 & 1.89 & \begin{tabular}{|l|}
5.78 \\
\end{tabular} & 8.63 & 11.05 & 13.05 & 16.02 & 0.36 \\
\hline in-situ soil & 1.05 & 5.44 & 9.97 & 14.87 & 20.13 & 24.8 & 30.02 & 1.14 \\
\hline \multicolumn{9}{|l|}{ Summary } \\
\hline ressure & Opsi & 5 & 10 & 15 & 20 & 25 & & 24hour \\
\hline$a x d$ & & & 0.029 & & 0.127 & & 0.1327 & \\
\hline avg. $p$ & & & 9.18 & & 15.94 & & 21.645 & \\
\hline
\end{tabular}

\section{6 inch trench}

\begin{tabular}{|l|r|r|r|r|r|r|r|r|}
\hline pressure & Opsi & 5 & 10 & 15 & 20 & 25 & 30 & 24 hour \\
\hline deflection 1 & 0.0004 & -0.0098 & -0.0355 & -0.0629 & -0.0918 & -0.1183 & -0.1421 & -0.1173 \\
\hline deflection 2 & -0.0469 & -0.0469 & -0.0665 & -0.0935 & -0.1209 & -0.1462 & -0.1698 & -0.1698 \\
\hline deflection 3 & 0.0013 & $\#$ & $\#$ & $\#$ & $\#$ & $\#$ & $\#$ & $\#$ \\
\hline center stress & 2.23 & 8.71 & 17.66 & 24.33 & 27.92 & 30.95 & 32.82 & 9.97 \\
\hline center stress & -1.48 & 4.73 & 13.94 & 21.52 & 25.73 & 29.31 & 31.52 & 5.42 \\
\hline in-situ soil & 1.18 & 3.98 & 7.16 & 10.43 & 13.72 & 17.25 & 20.54 & 0.77 \\
\hline
\end{tabular}

Summary

\begin{tabular}{|l|l|r|r|r|r|r|r|r|}
\hline pressure & 0psi & 5 & 10 & 15 & 20 & 25 & 30 & 24 hour \\
\hline max d & & & 0.0359 & & 0.0922 & & 0.1425 & \\
\hline avg. $p$ & & & 15.8 & & 26.825 & & 32.17 & \\
\hline
\end{tabular}

\section{0 inch trench}

\begin{tabular}{|c|c|c|c|c|c|c|c|c|}
\hline ressure & Opsi & 5 & 10 & 15 & 20 & 25 & 30 & 24 hour \\
\hline deflection 1 & 0.1114 & 0.1054 & 0.0845 & 0.0594 & 0.0443 & 0.0248 & \begin{tabular}{|l|}
0.0078 \\
\end{tabular} & 0.0325 \\
\hline deflect & 0.0853 & 0.0853 & 0.0721 & 0.0468 & 0.0329 & -0.0139 & -0.0031 & $\overline{0034}$ \\
\hline deflec & -0.0986 & -0.0971 & -0.0828 & -0.0612 & -0.0476 & -0.0285 & -0.0106 & .0145 \\
\hline center & 2 & 5.78 & 13.56 & 17.01 & 21.11 & 23.49 & 25.87 & 8.06 \\
\hline center & -1.64 & 0.31 & 6.1 & 10.68 & 15.36 & 18.31 & 21.1 & 2.63 \\
\hline in-situ s & 0.64 & 4.3 & 8.69 & 12.81 & 17.52 & 22.56 & 27.91 & 0.32 \\
\hline \multicolumn{9}{|l|}{ Summary } \\
\hline ressure & Opsi & 5 & 10 & 15 & 20 & 25 & 30 & 24hour \\
\hline axd & & & 0.0269 & & 0.0671 & & 0.106 & \\
\hline vg. $p$ & & & 9.83 & & 18.235 & & 23.485 & \\
\hline
\end{tabular}




\section{Collected Data for 8 inch Pipes}

Low Strength In-Situ Soil with Low Strength CLSM

12 inch trench

\begin{tabular}{|l|l|r|r|r|r|r|r|r|}
\hline pressure & Opsi & 5 & 10 & 15 & 20 & 25 & 30 & 24 hour \\
\hline deflection 1 & -0.0782 & -0.0091 & 0.0914 & 0.2083 & 0.2825 & 0.3678 & 0.4562 & 0.2144 \\
\hline deflection 2 & -0.0506 & -0.1308 & -0.2378 & -0.3604 & -0.4353 & -0.5246 & -0.6141 & -0.353 \\
\hline deflection 3 & 0.065 & 0.155 & 0.277 & 0.4 & 0.481 & 0.573 & 0.661 & 0.432 \\
\hline center stress & 2.14 & 7.31 & 11.56 & 14.96 & 18.64 & 21.35 & 24.52 & 2.84 \\
\hline center stress & 0.47 & 5.78 & 8.84 & 11.1 & 13.94 & 16.15 & 18.89 & 1.42 \\
\hline in-situ soil & 0.22 & 3.98 & 8.05 & 13.08 & 17.71 & 22.65 & 28.55 & 0.45 \\
\hline Summary & \multicolumn{7}{|l|}{} \\
\hline pressure & Opsi & 5 & 10 & 15 & 20 & 25 & 30 & 24 hour \\
\hline max d & & & 0.212 & & 0.416 & & 0.596 & \\
\hline avg.p & & & 10.2 & & 16.29 & & 21.705 & \\
\hline
\end{tabular}

\section{6 inch trench}

\begin{tabular}{|l|l|r|r|r|r|r|r|r|}
\hline pressure & Opsi & 5 & 10 & 15 & 20 & 25 & 30 & 24 hour \\
\hline deflection 1 & -0.0264 & 0.0711 & 0.1991 & 0.3211 & 0.4146 & 0.5182 & 0.5893 & 0.2855 \\
\hline deflection 2 & 0.0398 & -0.0609 & -0.1965 & -0.3227 & -0.4165 & -0.5193 & -0.5896 & -0.2573 \\
\hline deflection 3 & -0.058 & 0.047 & 0.185 & 0.314 & 0.397 & 0.481 & 0.551 & 0.257 \\
\hline center stress & 3.03 & 8.34 & 11.65 & 14.31 & 16.59 & 18.64 & 20.13 & 5.31 \\
\hline center stress & 0.52 & 5.15 & 8.52 & 11.57 & 14.31 & 16.94 & 19.05 & 2.42 \\
\hline in-situ soil & 0.13 & 2.83 & 7.09 & 11.53 & 15.65 & 20.36 & 23.97 & 0.45 \\
\hline Summary & \multicolumn{7}{|l|}{} \\
\hline pressure & Opsi & 5 & 10 & 15 & 20 & 25 & 30 & 24 hour \\
\hline max d & & & 0.243 & & 0.455 & & 0.6294 & \\
\hline avg. p & & & 10.085 & & 15.45 & & 19.59 & \\
\hline
\end{tabular}

\section{0 inch trench}

\begin{tabular}{|l|r|r|r|r|r|r|r|r|}
\hline pressure & Opsi & 5 & 10 & 15 & 20 & 25 & 30 & 24 hour \\
\hline deflection 1 & 0.0264 & 0.063 & 0.1056 & 0.1839 & 0.2825 & 0.3455 & 0.4349 & 0.2439 \\
\hline deflection 2 & -0.0281 & -0.0621 & -0.0976 & -0.1648 & -0.2562 & -0.3145 & -0.4023 & -0.2097 \\
\hline deflection 3 & 0.018 & 0.046 & 0.082 & 0.149 & 0.235 & 0.288 & 0.367 & 0.209 \\
\hline center stress & 1.53 & 2.75 & 3.35 & 3.82 & 4.28 & 4.7 & 5.36 & 1.95 \\
\hline center stress & -0.16 & 5 & 7.73 & 10.78 & 13.26 & 15.31 & 17.26 & 2 \\
\hline in-situ soil & 0 & 5.17 & 9.42 & 15.42 & 22.24 & 27 & 33.13 & 0.68 \\
\hline $\begin{array}{l}\text { Summary } \\
\text { pressure }\end{array}$ & Opsi & 5 & 10 & 15 & 20 & 25 & 30 & 24 hour \\
\hline max d & & & 0.0792 & & 0.2561 & & 0.4085 & \\
\hline avg. p & & & 7.73 & & 13.26 & & 17.26 & \\
\hline
\end{tabular}

\section{4 inch trench}

\begin{tabular}{|l|r|r|r|r|r|r|r|r|}
\hline pressure & 0psi & 5 & 10 & 15 & 20 & 25 & 30 & $24 \mathrm{hour}$ \\
\hline deflection 1 & -0.003 & -0.0042 & 0.118 & 0.222 & 0.322 & 0.409 & 0.496 & 0.23 \\
\hline deflection 2 & -0.0386 & -0.0519 & 0.1251 & 0.2263 & 0.328 & 0.4115 & 0.5012 & 0.2326 \\
\hline deflection 3 & $\#$ & & & & & & & \\
\hline center stress & 2.56 & 5.87 & 7.31 & 9.05 & 10.9 & 13.12 & 14.68 & 2.75 \\
\hline center stress & -0.85 & 5.36 & 7.78 & 11.17 & 13.36 & 16.37 & 19.26 & 0.73 \\
\hline in-situ soil & 1.09 & 3.56 & 6.4 & 13.56 & 16.15 & 21.11 & 26.04 & 0.77 \\
\hline $\begin{array}{l}\text { Summary } \\
\text { pressure }\end{array}$ 0psi & 5 & 10 & 15 & 20 & 25 & 30 & $24 \mathrm{hour}$ \\
\hline max d & & & 0.121 & & 0.325 & & 0.499 & \\
\hline avg. p & & & 7.545 & & 12.13 & & 16.97 & \\
\hline
\end{tabular}




\section{Appendix D \\ Calculations for the Pipe Testing Apparatus}


Refer to Figure 3.1, Figure 3.2, and Figure 3.3 in chapter 3 for the schematic diagrams of the pipe testing apparatus.

\section{1.) Reinforcing Bars}

Each side of the test box is reinforced with three steel angles. The deflection of the angles needs to be controlled. Each side can be modeled as a fixed-fixed connection with the load evenly distributed between the three reinforced angles.
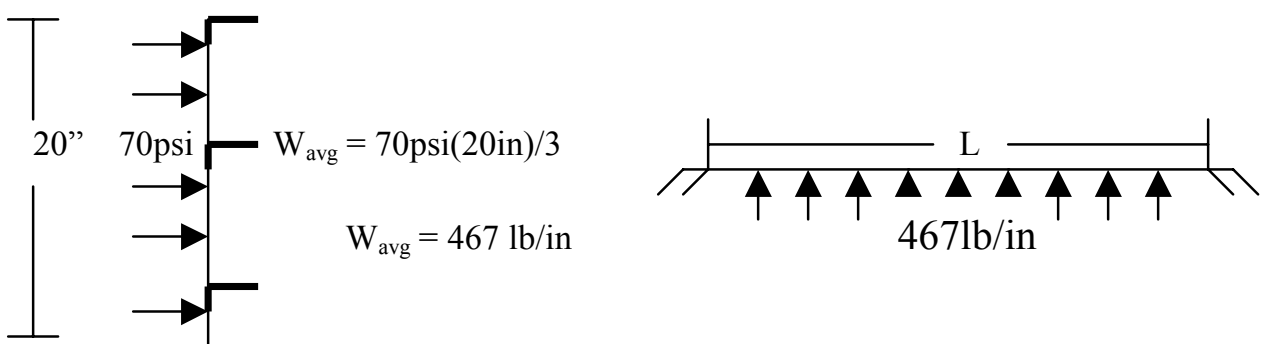

Using Equation 3.1

$$
. \mathrm{y}=(\mathrm{W})\left(\mathrm{L}^{4}\right) / 384(\mathrm{E})(\mathrm{I})
$$

Using $\mathrm{y}=0.01$ and $\mathrm{E}=29,000 \mathrm{ksi}$, The minimum moment of inertia (I), that is required for the reinforcing members can be calculated.

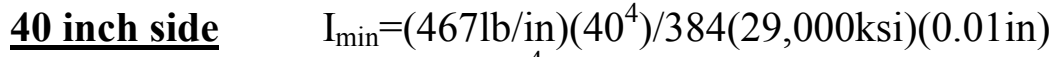

$$
\mathrm{I}_{\min }=10.74 \mathrm{in}^{4}
$$

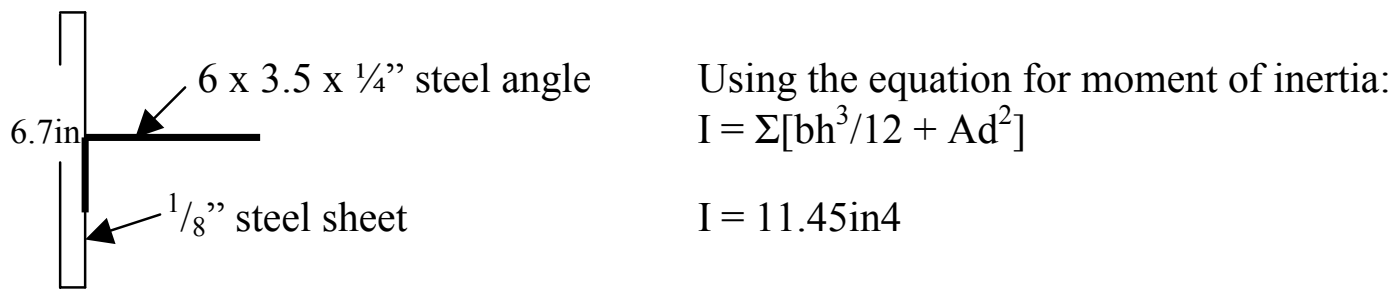

This number was substituted back into the original equation to find the expected deflections on the forty-inch side of the box.

$$
\begin{aligned}
& . y=(467 \mathrm{lb} / \mathrm{in})\left(40^{4}\right) / 384(29,000 \mathrm{ksi})\left(11.45 \mathrm{in}^{4}\right) \\
& . y=0.0091 \mathrm{in}
\end{aligned}
$$




\section{5 inch side}

$\mathrm{I}_{\min }=(467 \mathrm{lb} / \mathrm{in})\left(25^{4}\right) / 384(29,000 \mathrm{ksi})(0.01 \mathrm{in})$

$$
\mathrm{I}_{\min }=1.64 \mathrm{in}^{4}
$$

$$
\begin{aligned}
& 3 \times 31 / 4 " \text { steel angle } \\
& \mathrm{I}=1.68 \mathrm{in}^{4} \\
& \mathrm{I}=\Sigma\left[\mathrm{bh}^{3} / 12+\mathrm{Ad}^{2}\right] \\
& . \mathrm{y}=(467 \mathrm{~b} / \mathrm{in})\left(25^{4}\right) / 384(29,000 \mathrm{ksi})\left(1.68 \mathrm{in}^{4}\right) \\
& . \mathrm{y}=0.0098 \mathrm{in}
\end{aligned}
$$

\section{2.) Bottom and Lid Reinforcements}

The bottom required similar reinforcement as the 25 inch side because it is effectively two pieces that are both 25 inch by 20 inch. However, the bottom was reinforced much stronger than it needs to be because extra reinforcement was used to accommodate a footing for the box. The two lid pieces are also the same size ( 25 inch by 20 inch) but they are supported with four 3 inch $x 3$ inch x $1 / 4$ inch thick members because they could not be spaced in a way to evenly distribute the load because of instrumentation that must pass through the lid. Both of these areas used the information in the above equations and are much stronger than they need to be.

\section{3.) Lid Fasteners}

The lid will be held on by $1 / 2$ inch diameter bolts with a manufacturer specified yield strength equal to 70,000 psi. Using Equation 3.3 the average stress in all the bolts can be calculated.

$$
\begin{array}{ll}
\sigma=(\mathrm{P})(\mathrm{FS}) /(\mathrm{A})(\mathrm{N}) & \\
\mathrm{A}=\text { cross sectional area of a bolt }=\pi / 4\left({ }^{1} / 2\right)^{2} & =0.196 \mathrm{in}^{2} \\
\mathrm{~N}=\text { number of bolts to be used } & =70 \mathrm{k} \\
\mathrm{P}=\text { Total load }=70 \mathrm{psi}(40 \mathrm{in})(25 \mathrm{in}) & =2.5 \\
\mathrm{FS}=\text { factor of safety }(\text { assumed }) & =46.7 \mathrm{ksi} \\
\sigma_{\text {design }}=2 / 3 \sigma_{\text {yield }}=2 / 3(70,000 \mathrm{psi}) &
\end{array}
$$


Solving for the number of bolts needed:

$$
\begin{aligned}
& \mathrm{N}=(70 \mathrm{k})(2.5) /\left(0.196 \mathrm{in}^{2}\right)(46.7 \mathrm{ksi}) \\
& \mathrm{N}=19.12 \text { bolts } \\
& \therefore \text { Use } 20 \text { 1/2” diameter bolts }
\end{aligned}
$$

Next, by rearranging Equation 3.3 to obtain Equation 3.4, the actual factor of safety in the bolts can be solved as:

$$
\begin{aligned}
& \mathrm{FS}=\sigma_{\text {design }}(\mathrm{A})(\mathrm{N}) /(\mathrm{P}) \\
& \mathrm{FS}=(46.7 \mathrm{ksi})(0.196)(20) / 70 \mathrm{k} \\
& \mathrm{FS}=2.62
\end{aligned}
$$

\section{4.) Weld Strength}

The weld strength was calculated using the weld lengths of each side and the total force exerted on each side. Eq. (3.5) from the text, is the equation that was used:

$$
\sigma_{\text {weld }}=0.3 \sigma_{\text {tensile }} 0.707 \omega
$$

This equation specifies a strength per unit length of weld, where $\omega$ is the thickness of the member being welded, and $\sigma_{\text {tensile }}$ for the weld material is 60,000 psi. Solving these equations for $1 / 8$ " welds and $1 / 4$ " welds, gives the following results.

$$
\begin{aligned}
& \sigma_{\text {weld }} \text { for } 1 / 8 \text { " welds }=1590 \mathrm{lb} / \text { in } \\
& \sigma_{\text {weld }} \text { for } 1 / 4 " \text { welds }=3180 \mathrm{lb} / \text { in }
\end{aligned}
$$


25 inch side

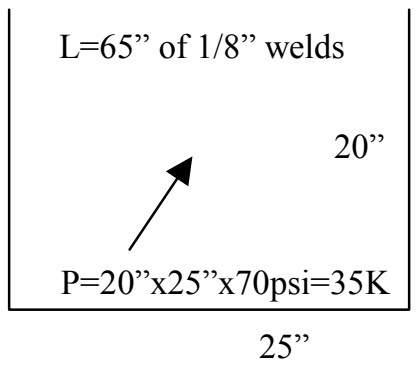

40 inch side

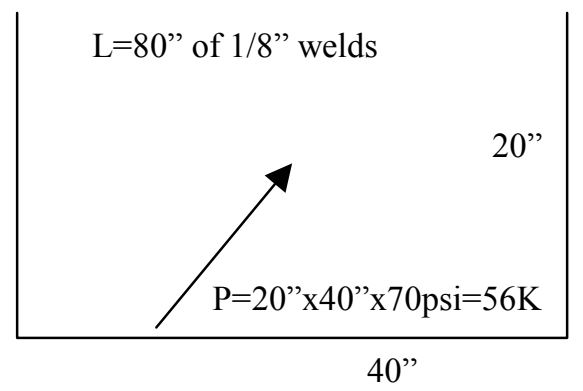

There is an additional 24 inch of $1 / 4$ inch weld from the reinforcing members that adds to the strength of this welded section. Using Equation 3.6:

$$
\begin{aligned}
& \mathrm{FS}=\Sigma \sigma_{\text {weld }} * \mathrm{~L} / \mathrm{P} \\
& \mathrm{FS}=1590 \mathrm{lb} / \mathrm{in} * 65 \mathrm{in} / 35 \mathrm{k}+3180 \mathrm{lb} / \mathrm{in} * 24 \mathrm{in} / 35 \mathrm{k} \\
& \mathrm{FS}=5.13
\end{aligned}
$$

There is an additional 24 inch of $1 / 4$ inch weld from the reinforcing members that adds to the strength of this welded section. Using Equation 3.6:

$\mathrm{FS}=\Sigma \sigma_{\text {weld }} * \mathrm{~L} / \mathrm{P}$

$\mathrm{FS}=1590 \mathrm{lb} / \mathrm{in} * 80 \mathrm{in} / 56 \mathrm{k}+3180 \mathrm{lb} / \mathrm{in} * 24 \mathrm{in} / 56 \mathrm{k}$

$\mathrm{FS}=3.63$ 


\section{Bottom}

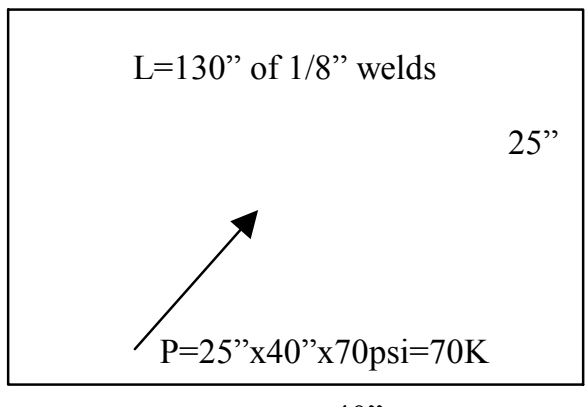

$\mathrm{FS}=\Sigma \sigma_{\text {weld }} * \mathrm{~L} / \mathrm{P}$

$\mathrm{FS}=1590 \mathrm{lb} / \mathrm{in} * 130 \mathrm{in} / 70 \mathrm{k}$

$\mathrm{FS}=2.95$

\section{Top Rim of Reinforcement}

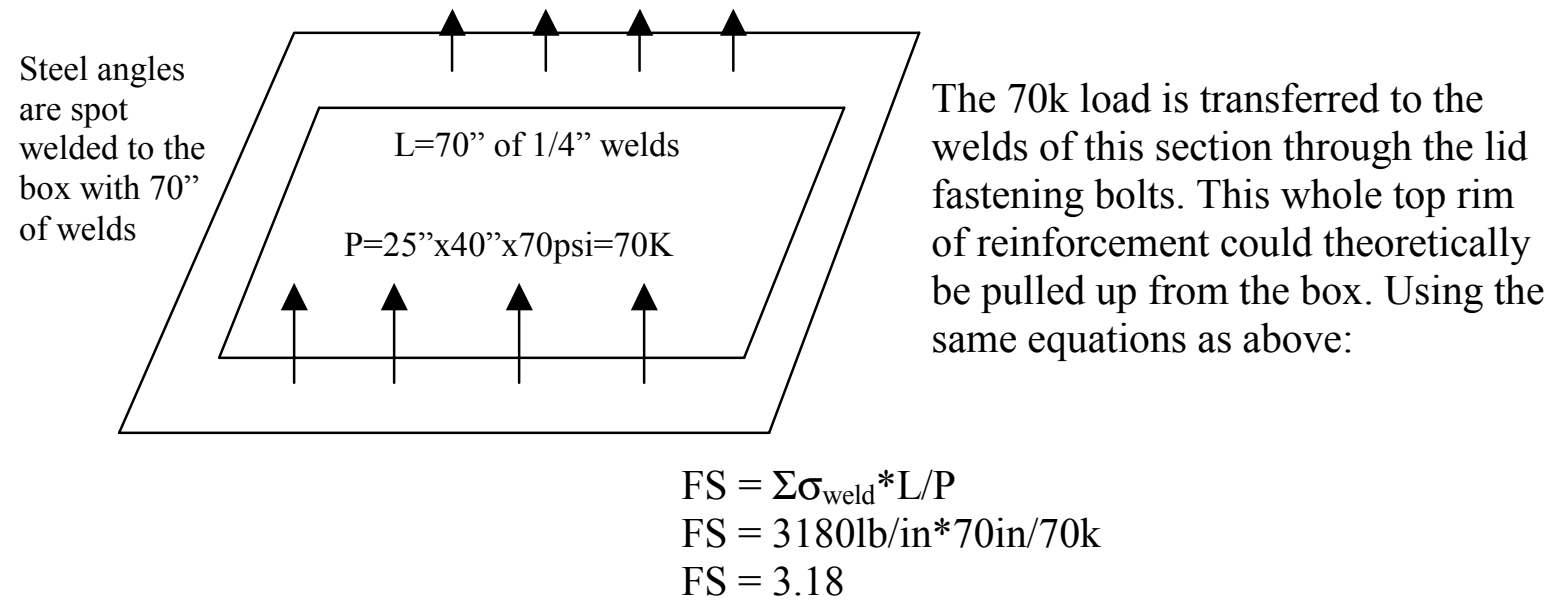

Load is transferred to the top rim through the bolts that hold down the lid

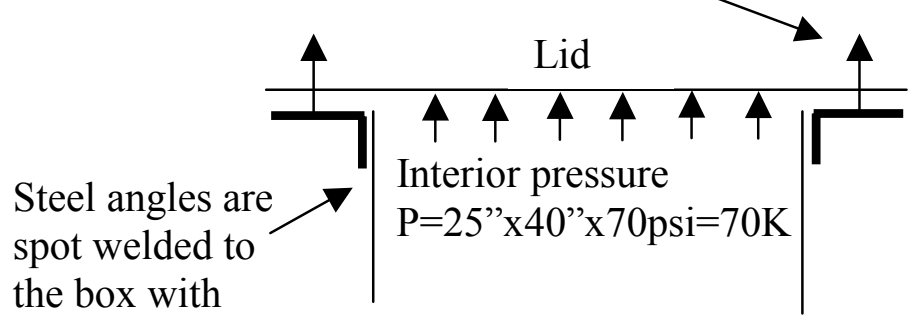

70 " of welds 


\section{Design of the Testing Apparatus at 32 psi Operating Pressure}

In the experimental procedures, the pressure did not exceed 32 psi. This means that the actual factors of safety, and the actual deflections in the experimental program will be much more conservative than the previously calculated numbers. All of the calculations have been linear with respect to the applied pressure, so the recalculation of all of these numbers is a simple process.

Expected deflections in the box on the 40 -inch side.

$$
\text { From Eq. (3.1).y }=(\mathrm{W})\left(\mathrm{L}^{4}\right) / 384(\mathrm{E})(\mathrm{I})
$$

$$
. \mathrm{y}=32 \mathrm{psi}(20 / 3)\left(40^{4}\right) /(384)(29,000 \mathrm{ksi})\left(11.45 \mathrm{in}^{4}\right) \quad=0.004 ”
$$

Expected deflections in the box on the 25 -inch side.

From Eq. (3.1) $. \mathrm{y}=(\mathrm{W})\left(\mathrm{L}^{4}\right) / 384(\mathrm{E})(\mathrm{I})$

$$
. \mathrm{y}=32 \mathrm{psi}(20 / 3)\left(25^{4}\right) /(384)(29,000 \mathrm{ksi})\left(1.68 \mathrm{in}^{4}\right) \quad=0.004^{\prime \prime}
$$

Factor of safety against failure of the lid bolts.

From Eq. (3.4) $\mathrm{FS}=\sigma_{\text {design }}(\mathrm{A})(\mathrm{N}) /(\mathrm{P})$

$$
\mathrm{FS}=46.7 \mathrm{k}\left(0.196 \mathrm{in}^{2}\right)(20) /(32 \mathrm{psi})(40 \mathrm{in} \times 25 \mathrm{in}) \quad=5.72
$$

Factor of safety against failure of the welds on the 25-inch side.

From Eq. (3.6) $\mathrm{FS}=\Sigma \sigma_{\text {weld }} * \mathrm{~L} / \mathrm{P}$

$$
\mathrm{FS}=[1590 \mathrm{lb} / \mathrm{in}(65 \mathrm{in})+3180 \mathrm{lb} / \mathrm{in}(24 \mathrm{in})] /(32 \mathrm{psi})(25 \mathrm{in} \times 20 \mathrm{in}) \quad=11.22
$$

Factor of safety against failure of the welds on the 40-inch side.

From Eq. (3.6) $\mathrm{FS}=\Sigma \sigma_{\text {weld }} * \mathrm{~L} / \mathrm{P}$

$$
\mathrm{FS}=[1590 \mathrm{lb} / \mathrm{in}(80 \mathrm{in})+3180 \mathrm{lb} / \mathrm{in}(24 \mathrm{in})] /(32 \mathrm{psi})(40 \mathrm{in} \times 20 \mathrm{in}) \quad=7.94
$$

Factor of safety against failure of the welds on the bottom of the box.

From Eq. (3.6) $\mathrm{FS}=\Sigma \sigma_{\text {weld }} * \mathrm{~L} / \mathrm{P}$

$$
\mathrm{FS}=[1590 \mathrm{lb} / \mathrm{in}(130 \mathrm{in})] /(32 \mathrm{psi})(40 \mathrm{in} \times 25 \mathrm{in}) \quad=6.45
$$


Factor of safety against failure of the welds on the top rim of reinforcement.

From Eq. (3.6) $\mathrm{FS}=\Sigma \sigma_{\text {weld }} * \mathrm{~L} / \mathrm{P}$

$$
\mathrm{FS}=[3180 \mathrm{lb} / \mathrm{in}(70 \mathrm{in})] /(32 \mathrm{psi})(40 \mathrm{in} \times 25 \mathrm{in}) \quad=6.96
$$

\section{Design of the Reaction Frame.}

The Reaction Frame is supported by four 3 inch $x 3$ inch x $1 / 4$ inch vertical steel angles that are bolted to the footing of the test box. It was designed to apply direct axial loading onto the soil. The load beam was designed in the same way as the reinforcing members, using the equation for deflection to solve for a minimum moment of inertia. The load beam can be modeled like a pin-pin beam with a center load of 10,000 lb, the maximum applied load. Equation 3.7 was used.

\section{Choosing a load bar}

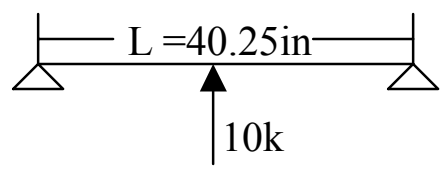

$$
\begin{aligned}
& . y=(P)\left(\mathrm{L}^{3}\right) / 48(\mathrm{E})(\mathrm{I}) \\
& \text { Rearranging to obtain } \\
& \mathrm{I}=(\mathrm{P})\left(\mathrm{L}^{3}\right) / 48(\mathrm{E})(\mathrm{y})
\end{aligned}
$$

A maximum deflection of $\mathrm{y}=0.02$ inch and Young's modulus of $\mathrm{E}=29,000 \mathrm{ksi}$ were used.

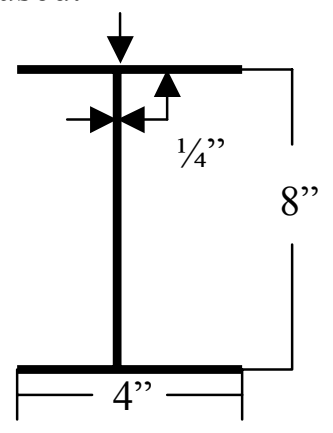

$$
\begin{aligned}
& \mathrm{I}=(10 \mathrm{k})(40.25 \mathrm{in})^{3} /(48)(29,000 \mathrm{ksi})(0.02 \mathrm{in}) \\
& I=23.4 \mathrm{in}^{4}
\end{aligned}
$$

A $4 \times 8 \times 1 / 4$ " I-beam was used.

$$
\begin{aligned}
& \mathrm{I}=\Sigma\left[\mathrm{bh}^{3} / 12+\mathrm{Ad}^{2}\right] \\
& \mathrm{I}=38.8 \mathrm{in}^{4}
\end{aligned}
$$

Substituting back into Equation 3.7, the maximum expected deflection can be calculated.

$$
\begin{aligned}
& . y=(10 \mathrm{k})(40.25 \mathrm{in})^{3} /(48)(29,000 \mathrm{ksi})\left(38.8 \mathrm{in}^{4}\right) \\
& . \mathrm{y}=0.012 \mathrm{in}
\end{aligned}
$$




\section{Shearing of the bolts}

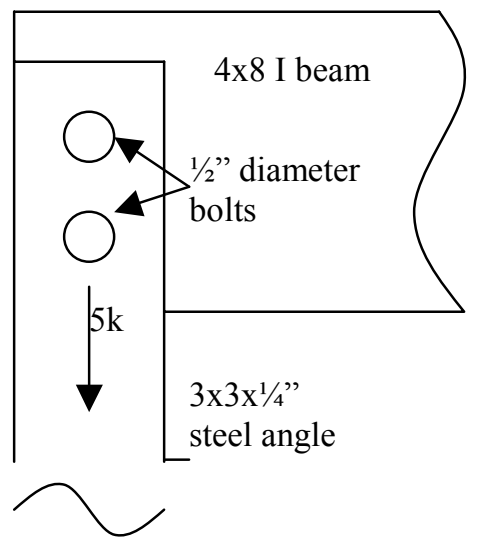

The load bar has two $1 / 2$ " bolts at each connection, with a manufacturer specified yield strength of 70,000 psi. By considering the free body diagram, it can be shown that there is 5,000lb acting on each side, therefore, each bolt must hold 2,500lb in a double shear configuration. Using equations 8, 9, and 10 the factor of safety against bolt failure can be found.

The stress induced in the bolts is found with Equation 3.9

$$
\begin{aligned}
& \sigma=\mathrm{P} / 2 \mathrm{~A} \\
& \sigma=2,5001 \mathrm{~b} / 2\left(0.196 \mathrm{in}^{2}\right) \\
& \sigma=6377.55 \mathrm{psi}
\end{aligned}
$$

The design shear stress is found with Equation 3.8

$$
\begin{aligned}
& \sigma_{\text {shear }}=0.5 \sigma_{\text {design }} \\
& \sigma_{\text {shear }}=0.5(2 / 3 * 70,000 \mathrm{psi}) \\
& \sigma_{\text {shear }}=23,333.33 \mathrm{psi}
\end{aligned}
$$

Factor of safety is the ratio of these two numbers as in Equation 3.10

$$
\begin{aligned}
& \mathrm{FS}=\sigma_{\text {shear }} / \sigma \\
& \mathrm{FS}=23,333.33 \mathrm{psi} / 6377.55 \mathrm{psi} \\
& \mathrm{FS}=3.67
\end{aligned}
$$




\section{Shearing of the supports}

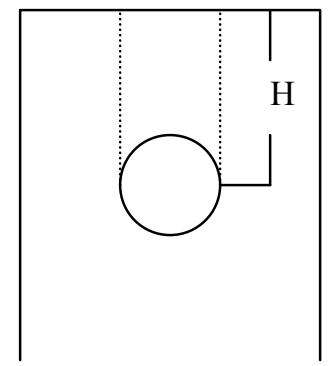

The steel in the web is also subject to failure. It is only $1 / 4$ " thick and must carry the load from the bolts. The spacing of the bolts is 2 " and the specified yield strength of the steel is 60,000psi. Since this portion is not in double shear the equation for the induced shear stress is Equation 3.11, and the area is found with Equation 3.12.

The area of the potential failure is found with Equation 3.12

$$
\begin{aligned}
& A=H(2)(1 / 4 \text { in }) \\
& A=2 \operatorname{in}(2)(1 / 4 \text { in }) \\
& A=1 i^{2}
\end{aligned}
$$

The induced stress is calculated with Equation 3.11

$$
\begin{aligned}
& \sigma=\mathrm{P} / \mathrm{A} \\
& \sigma=2,500 \mathrm{lb} / \mathrm{in}^{2} \\
& \sigma=2,500 \mathrm{psi}
\end{aligned}
$$

The design shear stress is found with Equation 3.8

$$
\begin{aligned}
& \sigma_{\text {shear }}=0.5 \sigma_{\text {design }} \\
& \sigma_{\text {shear }}=0.5(2 / 3 * 60,000 \mathrm{psi}) \\
& \sigma_{\text {shear }}=20,000 \mathrm{psi}
\end{aligned}
$$

Factor of safety is the ratio of these two numbers as in Equation 3.10

$$
\begin{aligned}
& \mathrm{FS}=\sigma_{\text {shear }} / \sigma \\
& \mathrm{FS}=20,000 \mathrm{psi} / 2,500 \mathrm{psi} \\
& \mathrm{FS}=8
\end{aligned}
$$




\section{Horizontal bending of the load bar}

View from side

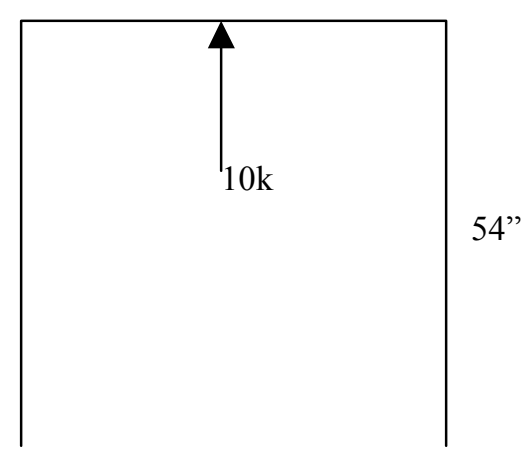

View from top

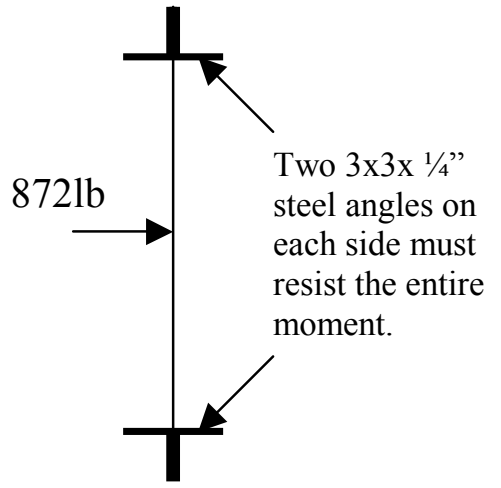

The load bar has a 54" moment arm measured from the bottom of the bar to the point of the applied load. assuming a maximum twist in the load equal to $5^{0}$, then the horizontal force that would cause an induced moment would be $\sin 5^{\circ}(10 \mathrm{k})$. This horizontal force is used in the equation for deflections of a cantilever section (Eq. (3.13)).

This number seams high but this is an expected maximum. All measures were taken to insure that there was no horizontal deflection of the load bar. 